\title{
S $_{\text {PeCial }} \mathbf{R}_{\text {EPoRt }} 57$
}

\section{Alaska’s Mineral Industry 2002}

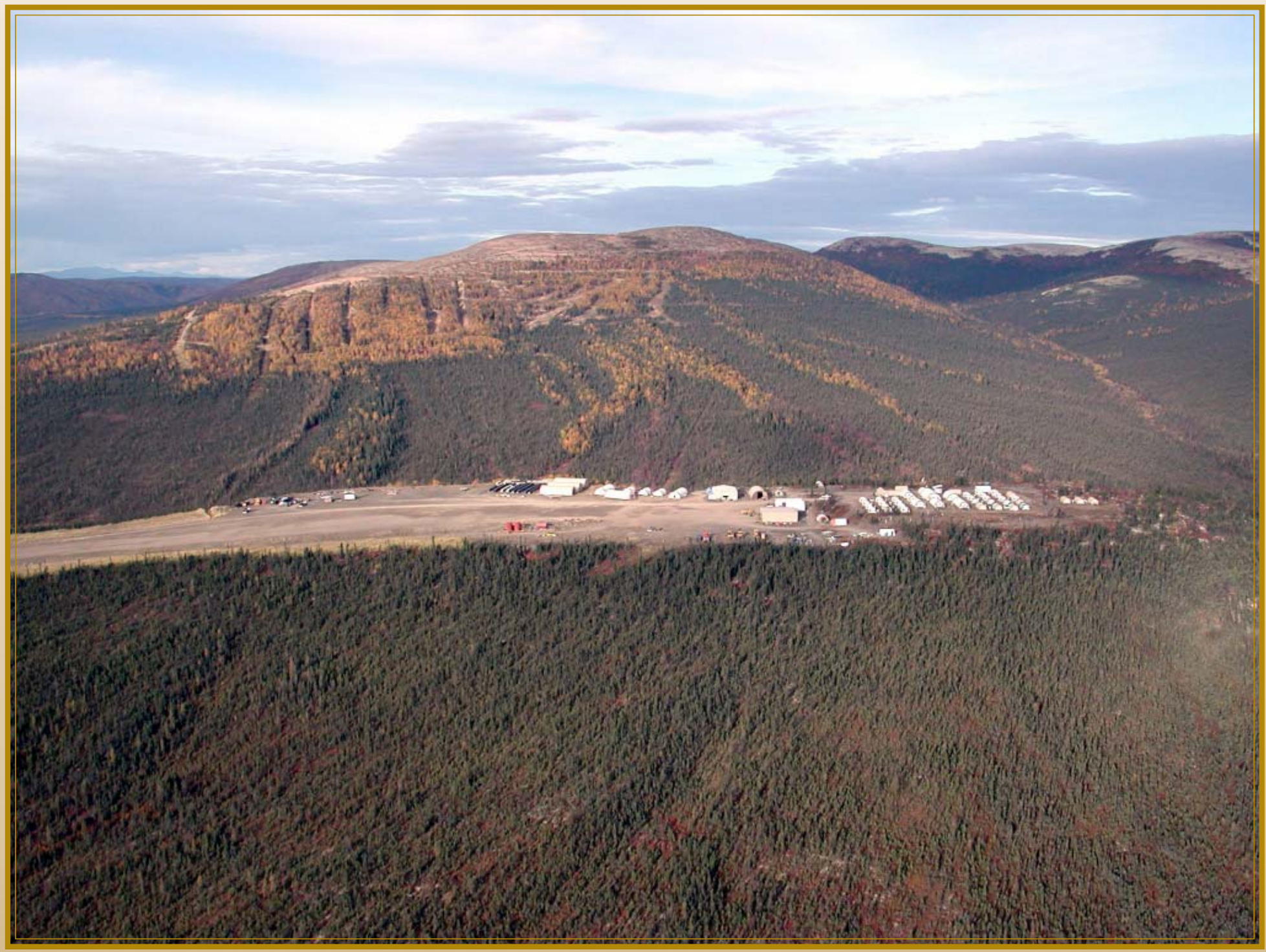

View looking north towards American Ridge with an 80-person tent camp and 5,000-foot runway, and valley and hills beyond containing the 23-million-ounce Donlin Creek gold resource. Most of the 2002 drill program at Donlin Creek was conducted in the valley of American Creek between the camp ridge and Lewis Ridge (in the photo's center). Photo courtesy of NovaGold Resources Inc.

Division of Geological \& Geophysical SuRveys in cooperation with Division of Community \& Business Development Division of Mining, Land \& Water 


\section{Alaska's Mineral Indusizy 2002}




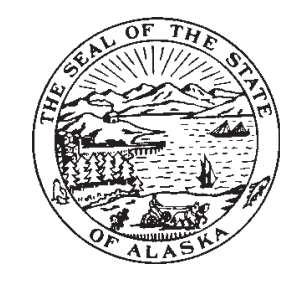

STATE OF ALASKA

Frank H. Murkowski, Governor

DEPARTMENT OF COMMUNITY \& ECONOMIC DEVELOPMENT

Edgar Blatchford, Commissioner

\author{
DIVISION OF COMMUNITY \& BUSINESS DEVELOPMENT \\ Margy Johnson, Director \\ DEPARTMENT OF NATURAL RESOURCES \\ Tom Irwin, Commissioner \\ DIVISION OF GEOLOGICAL \& GEOPHYSICAL SURVEYS \\ Rodney A.Combellick, Acting Director \\ DIVISION OF MINING, LAND \& WATER \\ Bob Loeffler, Director
}

DGGS publications may be inspected at the following locations. Address mail orders to the Fairbanks office.

\begin{abstract}
Alaska Division of Geological
\& Geophysical Surveys

ATTN: Geologic Communications

3354 College Rd.
\end{abstract}

Fairbanks, Alaska 99709-3707

Elmer E. Rasmuson Library

University of Alaska Fairbanks

Fairbanks, Alaska 99775-1005
University of Alaska Anchorage

Library

3211 Providence Drive

Anchorage, Alaska 99508

Alaska Resource Library
3150 C Street, Suite 100
Anchorage, Alaska 99503

Alaska State Library

State Office Building, 8th Floor

333 Willoughby Avenue

Juneau, Alaska 99811-0571 


\section{EXECUTIVE SUMMARY}

Alaska's Mineral Industry 2002 is the twenty-second in a series of annual reports. This report is part of a cooperative venture between the Division of Geological \& Geophysical Surveys (DGGS) and the Division of Mining, Land, \& Water (DMLW) in the Department of Natural Resources (DNR) and the Division of Community \& Business Development (DCBD) in the Department of Community \& Economic Development (DCED).

The 2002 cumulative value of Alaska's mining industry is $\$ 1.073$ billion, an increase of $\$ 50$ million from the $\$ 1.022$ billion reported in 2001. There was a 10 percent increase in exploration investment from 2001 ( $\$ 26.5$ million in 2002 versus $\$ 23.8$ million in 2001). The 58 percent decrease in mineral development investment to $\$ 34.1$ million in 2002 compared with the $\$ 81.2$ million reported in 2001 was more than offset by the $\$ 100$ million increased value of mineral products. Alaska's mineral production value was $\$ 1.01$ billion, rebounding from the 2001 value of $\$ 917$ million. Metals, with a value of $\$ 823$ million, accounted for 81 percent of total production; and zinc continued to be the most valuable metal in terms of total revenue generated.

Total minerals industry employment in 2002 was 2,824 full-time-equivalent jobs, a drop of 11 jobs from the 2,835 jobs reported in 2001. Declines were mostly in the development sector, counteracted by an increase in the lode gold mining and industrial minerals sectors.

One thousand five hundred thirty-one new state mining claims, 57 new state prospecting sites, and 261 new federal claims were staked in 2002. State claim staking increased from 2001 levels, while the number of new federal mining claims was the lowest in the past 10 years. Land under claim in Alaska continued to drop from 1999 levels, with approximately 2.6 million acres of land covered by claims and prospecting sites in 2002, a 29 percent drop from the 3.7 million acres under claim in 1999.

Drilling was conducted during all phases of mining (exploration, development, and production) and drilling totals for 2002 are 385,290 feet of core drilling and 103,612 feet of reverse-circulation drilling. The southwestern region had the most drilling of all Alaska regions, followed by the eastern interior and the southeastern regions.

Exploration during 2002 occurred across most regions of the state, with almost half of the exploration funds spent in southwestern Alaska. The eastern interior region saw a sharp reduction in activity, while the Seward Peninsula experienced a rebirth in activity. Several large projects accounted for most of the exploration expenditures and drill footage: Donlin Creek gold project (NovaGold Resources Inc.); Pebble copper-gold project (Northern Dynasty Minerals Ltd.); Greens Creek mine exploration (Kennecott Minerals Co./Hecla Mining Co.); and Fairbanks mining district gold projects (Kinross Gold Corp.). Gold remained the major exploration commodity, with more than \$17 million spent on exploration in 2002, although polymetallic exploration increased from recent levels. More than 72 percent of the exploration funds were derived from Canadian sources.

The decline in development investment mainly reflects completion of ongoing projects at Red Dog Mine in northern Alaska, but small projects were reported at the Fort Knox/True North complex, Usibelli Coal Mine, and Pogo Project in the interior, and at Kensington and Greens Creek mines in southeastern Alaska. Production at Greens Creek Mine reached record levels, and was robust at Fort Knox and Red Dog mines. The placer gold production level of 22,000 ounces was comparable to that of the previous year.

In government actions, the federal Mine Safety and Health Administration (MSHA) presented True North Mine with a Sentinels of Safety Award. Ray Lester and the U.S. Bureau of Land Management (BLM) received awards from DNR for reclamation activities. DGGS conducted a detailed, 300-person-day geologic mapping project in the Salcha River-Pogo (SRP) geophysical tract in the Big Delta Quadrangle. DGGS also contracted an airborne geophysical survey in the Council area east of Nome and released results of surveys flown in 2001 in the southeastern Pogo, Broad Pass, and Liberty Bell areas. Airborne geophysical surveys funded by BLM and managed by DGGS were flown in the southern Delta River area (Denali Block) west of Paxson, and in the Red Devil-Sleetmute area of southwestern Alaska. The U.S. Geological Survey (USGS) continued metallogenic studies at the Red Dog deposit, collected geochemical samples in southwestern Alaska including water samples in Donlin Creek and the surrounding area, and conducted gravity and magnetic geophysical studies on the Talkeetna Mountains Transect Project. BLM conducted a 7-week field program in the southern part of the Delta River mining district of eastern and southcentral Alaska. 
For the seventh consecutive year the mineral industry in our state has contributed more than $\$ 1$ billion to the Alaskan economy. While this is a noteworthy accomplishment in its own right, the fact that it has occurred during a serious downturn in the global economy is truly significant and a real testament to the hard working men and women of the Alaska mineral industry. I congratulate all of the state's miners and explorers on their remarkable accomplishment.

Alaska has a long and illustrious mining heritage. From the earliest gold seekers right up through today's high-tech mining operations, the discovery and production of minerals has been a significant part of Alaska's economy. I am proud of the hard working men and women of our mineral industry for the contributions they continue to make to Alaska and its future. As Governor I am dedicated to making sure unnecessary permitting procedures, unrealistic standards, and unresponsive administrators do not impede their efforts. I am happy to report that good progress has been made in the last year toward achieving this goal. In September work was completed on the Pogo Mine Environmental Impact Statement. This document will allow federal and state agencies to begin issuing permits for the Pogo Mine north of Delta Junction. This gold mining operation with gold reserves in excess of 5 million ounces will employ 500 people during construction and have a full-time workforce of 300 .

While large mines make a significant impact to the State's economy, I will not forget the family-size mining operations scattered across our wonderful state. These outstanding men and women represent the true heart and soul of Alaska's mining heritage. With the growing onslaught of federal mining regulations, these family operations need our help. In the past year the Department of Natural Resources completed work on a Memorandum of Understanding with the federal Bureau of Land Management that will allow our smaller mining operators access to the state bonding pool. This will allow them to fully comply with federal bonding requirements without bankrupting their operations.

While producing mines such as Greens Creek, Usibelli, Fort Knox, and Red Dog are the now of our mining economy, exploration is the key to the future. During a recent trip to Fairbanks, I was reminded of the old saying that if you want to go elephant hunting you have to go where the elephants are. When it comes to mineral resources, Alaska is elephant country. The world's mining companies know this and it is reflected in their continued evaluations at Donlin Creek, Pebble, and Kensington. Additional exploration continues as well in the Fairbanks mining district and adjacent to Greens Creek Mine in Southeast Alaska. I would remind everyone that as far as the mineral explorationist is concerned, Alaska is still a brand new province. In the 105 years since the Fortymile mining district was established (Alaska's first), the true mineral potential of our 365 million acres has only been scratched.

The Alaska mining industry is not immune to the world's economic conditions and we will always remain challenged by our climate and lack of infrastructure. Regardless of the barriers, I foresee a bright future for mining in Alaska. In the final analysis we have the resources and we have the people who know how to mine them. The combination of big mineral reserves and big Alaskan hearts will keep our state right at the forefront of mineral development for decades to come.

Governor Frank H. Murkowski 


\section{COMMISSIONERS' FOREWORDS}

The Department of Community \& Economic Development (DCED) and the Department of Natural Resources (DNR) are pleased to bring you the twenty-second annual report on Alaska's mineral industry.

The mission of DCED is to promote responsible development of Alaska's resources, including the state's mineral resources, both through promotion, and by investment in infrastructure through the Alaska Industrial Development and Export Authority (AIDEA). AIDEA has invested in the Red Dog Mine road and port, the coal loading facility in Seward, and the ore loading facility at Skagway. It has also participated in several projects to enhance the energy infrastructure of the state.

In 2002, for the seventh consecutive year, the total value of the industry exceeded $\$ 1$ billion, despite base metal prices that were the lowest in many years. The rising price of precious metals in the latter part of the year bodes well for the future profitability of mines that have struggled with low prices for the past five years. For the first time in several years industrial mineral production, especially of sand and gravel, showed a marked increase due to many public works projects.

Existing projects provided about 2,800 well paid jobs in 2002, and with the Pogo gold project north of Delta Junction, and the Kensington gold project north of Juneau in the advanced permitting process, there are likely to be several hundred more jobs available in the near future. Many of the mines are in remote areas, where jobs are scarce.

In the longer term, the Nixon Fork Mine near McGrath, prospects such as Donlin Creek and Pebble Copper in southwestern Alaska, Rock Creek gold property north of Nome, and numerous prospects along the south flank of the Brooks Range promise an exciting mining future in the state. Edgar Blatchford, Commissioner, Department of Community \& Economic Development

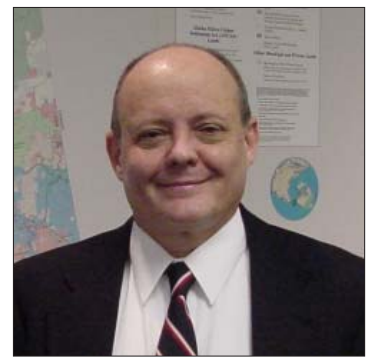

I join Governor Murkowski in congratulating the miners and explorers in Alaska for exceeding the billion-dollar mark for the seventh consecutive year. I believe that with the leadership from the Governor, along with the restructuring that has been completed in state government, we will experience a vital and exciting period of growth for the mining industry in our state.

In the last six months, changes to the permitting process have been made with the transfer of the Alaska Coastal Management Program and Division of Habitat to DNR. The department will continue to coordinate the permitting of all mine projects, large and small. We will build on the experience we have gained in past years and continue to improve the cooperative permitting environment.

Perhaps the most significant achievement of the past year is the publication of the final EIS for the Pogo gold project, near Delta Junction. At this writing, State and federal agencies are preparing to issue all necessary permits for this project. This high-grade, underground gold mine, situated entirely on state land, is the most exciting new mine development project to be permitted in Alaska in almost a decade. Pogo will add value to the industry in the coming years by providing hundreds of new, high-paying jobs and generating new revenues for the state. In addition, permitting efforts for expansions at Greens Creek mine are being finalized and work is in progress to update permits for the Red Dog zinc mine.

The conveyance of the eastern portion of the Denali Block to state ownership was completed in January. This area has displayed high potential for the discovery of platinum-group metals. We will pursue the conveyance of additional lands in this area, and in other mineral districts that have potential for significant mineral occurrences.

Coal continues to represent an important part of Alaska's mining industry with considerable potential. We are very pleased that Usibelli Coal Mine will once again be shipping coal from Seward to South Korea. In addition, HB 283 was passed by the Legislature that doubled the allowable acreage for coal leasing by a company.

Geophysical data for the Sleetmute quad were released in June, the most recent installment in providing useful geologic and geophysical data to encourage exploration efforts in attractive mineral districts throughout the state. DNR will continue to provide useful data to demonstrate our ongoing support for mineral exploration and development in Alaska.

The mining industry provides great potential for Alaska. With gold prices on the rise, we are looking forward to increased placer mining activity as well as resurgence in advanced exploration, development, and permitting activities at the Kensington, Donlin Creek, and Rock Creek properties. In addition, renewed interest is evident in properties such as the Nixon Fork, Pebble, and Little Squaw and at the Tulsequah Chief project in British Columbia.

DNR wants a strong mining industry and will continue to make wise and responsible decisions for the use of Alaska's land and natural resources. Tom Irwin, Commissioner, Department of Natural Resources 


\section{CONTENTS}

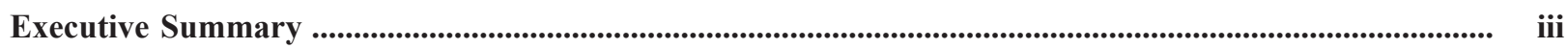

Introduction

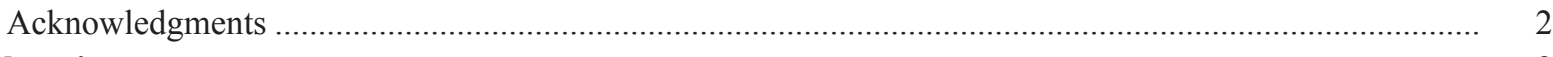

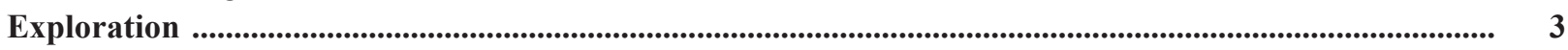

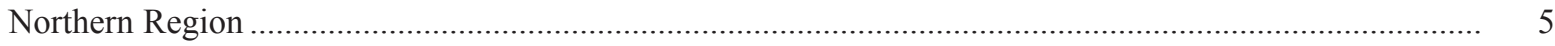

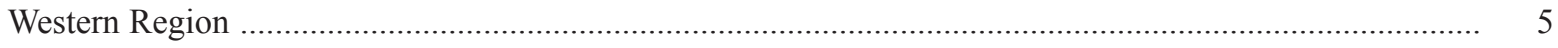

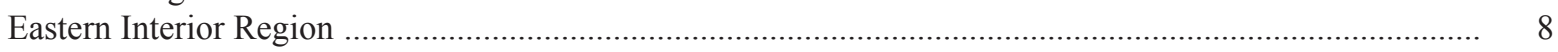

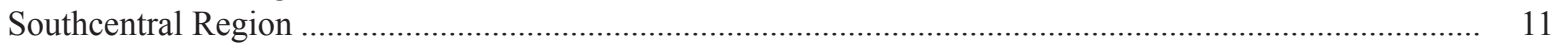

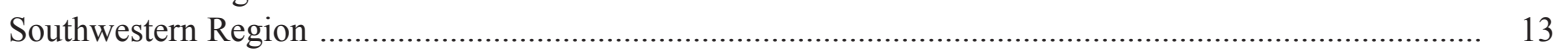

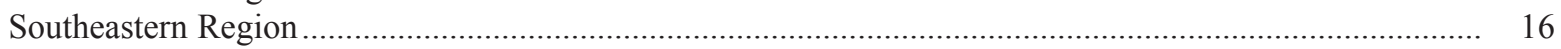

Development ...................................................................................................................................................... 17

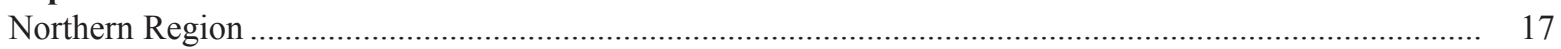

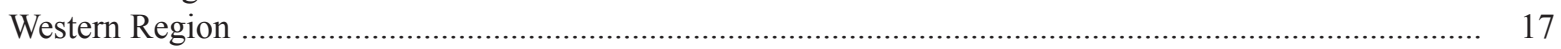

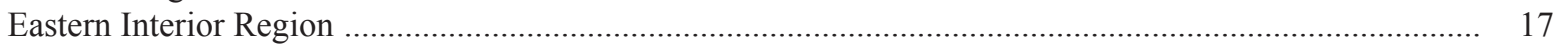

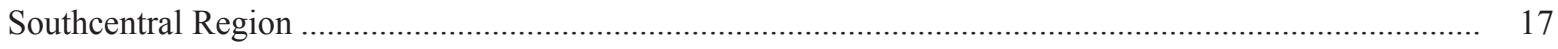

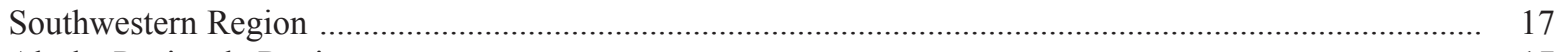

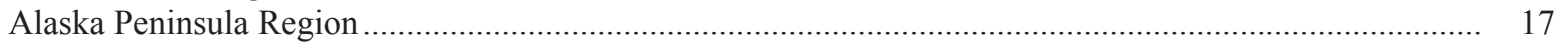

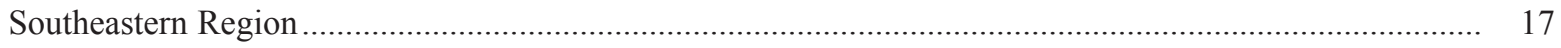

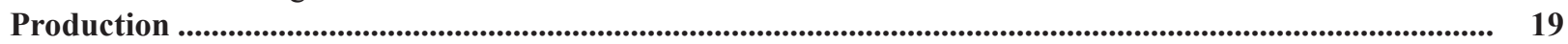

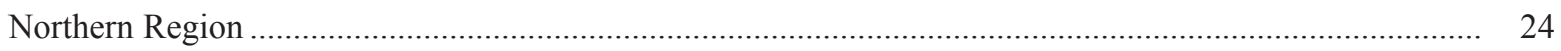

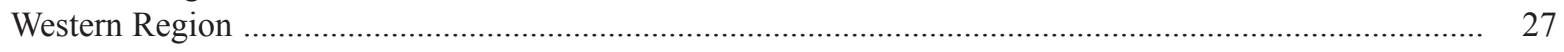

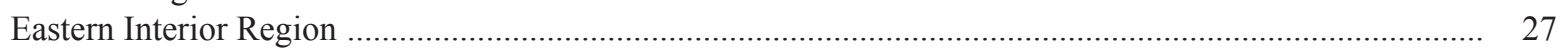

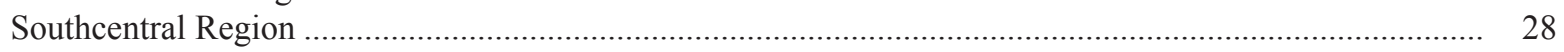

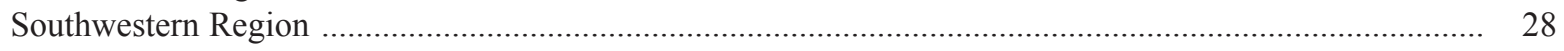

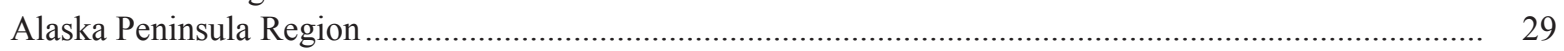

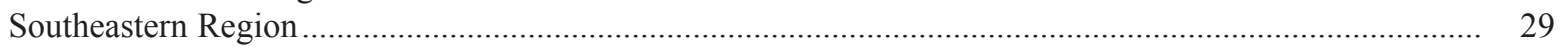

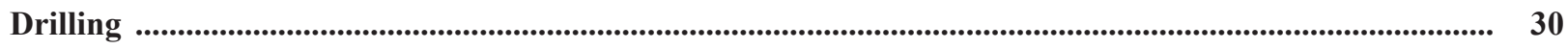

Government Actions ............................................................................................................................................... 31

Appendixes

A. New claims staked in Alaska, 1998-2002 ……............................................................................ 35

B. Prospecting sites in Alaska, 1996-2002 ……….......................................................................... 37

C. Selected significant mineral deposits and mineral districts in Alaska ..................................................... 39

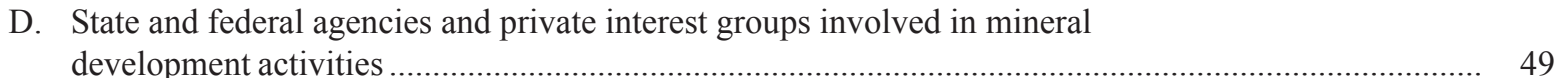

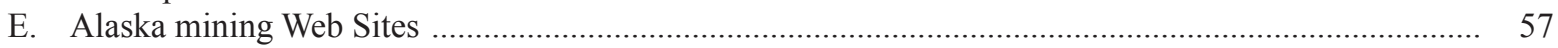

F. U.S. customary units and metric units conversion chart .................................................................... 59

G. Primary metals production in Alaska, 1880-2002 …..................................................................... 60

H. Production of industrial minerals, coal, and other commodities in Alaska, 1880-2002 _..................... 62

Figures

1. Map showing regions of mineral activity in Alaska as described in this report .....................................

2. Graph showing exploration and development expenditures and the value of production

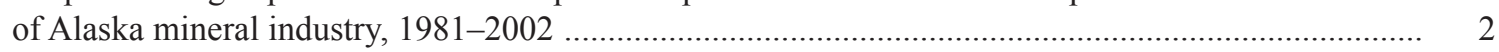

3. Chart showing 2002 mineral industry employment by category ........................................................... 3

4. Chart illustrating 2002 exploration expenditures by commodity .......................................................... 5

5. Map showing selected mineral exploration projects in Alaska, 2002 ............................................... 6

6. Photo showing DGGS geologist traversing through a chromite-bearing harzburgite and dunite ultramafic unit on Nail Ridge in the Salcha River-Pogo project area. .................................................. 8

7. Photo showing core drilling at the Hook Target on the Gobi-Portal property ....................................... 9

8. Photo showing core drilling by Nevada Star Resource Corp. on the Canwell nickel-copper-PGE prospect 


\section{CONTENTS}

9. Map of gold resource areas, 2002 core, and 2002 reverse-circulation holes at the Donlin Creek gold property

10. Map showing selected mineral development projects in Alaska, 2002 ............................................. 19

11. Graph showing sand and gravel production in Alaska, 1950-2002 .................................................. 24

12. Graph showing amount and value of gold production in Alaska, 1880-2002 ..................................... 24

13. Graph showing coal production in Alaska, 1915-2002, including exports to Korea ............................. 24

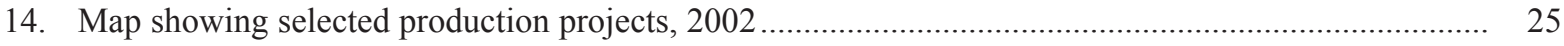

15. Photo of Illinois Creek Mine's East Pit ........................................................................................ 27

16. Photo of damaged road surface from the magnitude 7.9 Denali Earthquake of November 3, 2002 ....... 28

17. Photo of former DOT Commissioner Joseph Perkins and Maintenance Engineer Frank Richards examining the road surface along the Tok Cut-off Highway ................................................................ 29

18. Photo of drill helper unloading drill samples from core barrel into core boxes at the Donlin Creek gold property .....

19. Photo of BLM employee sampling "roundwash" for assessment of potential placer minerals ............... 33

Tables

1. Total value of the mineral industry in Alaska by year (in millions of dollars) ...................................... 2

2. Estimated Alaska mine employment, 1996-2002 …....................................................................... 3

3. Reported exploration expenditures and employment in Alaska, 2002 ………….............................. 4

4. Reported exploration expenditures in Alaska by commodity, 1982-2002 ……………….................... 4

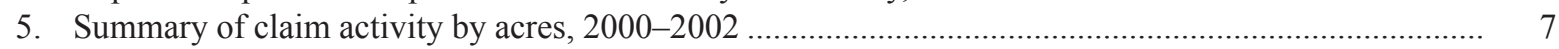

6. 2002 Donlin Creek gold resource estimates ..................................................................................... 13

7. Reported mineral development expenditures and employment in Alaska

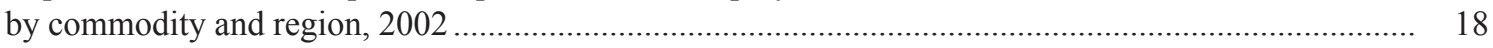

8. Reported mineral development expenditures in Alaska by commodity, 1982-2002 …........................ 18

9. Estimated mineral production in Alaska, 2000-2002 …................................................................. 20

10. Companies and individuals reported to be producing metal in Alaska, 2002 …................................ 20

11. Average metal prices, 1993-2002 ………................................................................................ 25

12. Reported refined gold production, number of operators, and industry employment, 2000-2002 .......... 25

13. Production for selected Alaska placer gold mines, 1996-2002 ....................................................... 26

14. Reported sand and gravel production and industry employment in Alaska by region, 2002 ................ 26

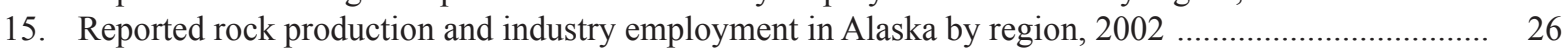

16. Red Dog Mine production statistics, 1989-2002 ............................................................................ 27

17. Fort Knox Gold Mine production statistics, 1996-2002 _................................................................. 28

18. Greens Creek Mine production statistics, 1989-2002 _........................................................................ 29

19. Companies reporting significant drilling programs in Alaska, 2002 ............................................. 30

20. Drilling footage reported in Alaska, 1982-2002 ....................................................................... 30

21. Drilling footage by region in Alaska, 2002 ................................................................................ 31

22. Detailed state airborne geophysical surveys and follow-up geologic ground-truthing .......................... 32

23. Detailed federal airborne geophysical survey work contracted by DGGS ......................................... 33

24. Revenues paid to the State of Alaska and municipalities by Alaska's mineral industry, 1997-2002 ...... 34 


\section{Alaska's Mineral Industry 2002 \\ D.J. Szumigala, ${ }^{1}$ R.C. Swainbank, ${ }^{2}$ M.W. Henning, ${ }^{3}$ and F.M. Pillifant ${ }^{4}$}

\section{INTRODUCTION}

This summary of Alaska's mineral industry activity for the year 2002 is the twenty-second in the series of annual reports, and is made possible by information provided through phone interviews, replies to many of the 838 questionnaires sent to participants in the mineral industry, press releases, and other sources of information. This report is part of a cooperative venture between the Division of Geological \& Geophysical Surveys (DGGS) and the Division of Mining, Land, \& Water (DMLW) in the Department of Natural Resources (DNR) and the Division of Community \& Business Development (DCBD) in the Department of Community \& Economic Development (DCED). Funds for printing the report are provided by the DCBD.

Figure 1 shows the regions of the state used in this and subsequent sections. Table 1 and figure 2 show the estimated value of the mineral industry in Alaska per year between 1981 and 2002, as divided between exploration and development investments, and the gross value of the mineral products. Company information is used to define the exploration and development parameters. Average metal prices are calculated from the daily London PM closing price for gold, and from the average weekly spot price on the London Metal Exchange for the other metals. These prices are used to calculate the value of metals produced in the state, but do not take into account the costs of mining or transportation, or smelter charges and penalties.

The 2002 cumulative value of Alaska's mining industry is $\$ 1.073$ billion, an increase of about $\$ 50$ million from the $\$ 1.022$ billion reported in 2001. The 10 percent increase in the exploration investment over the previous year (\$26.5 million in 2002 versus $\$ 23.8$ million in 2001) was counterbalanced by a 58 percent decrease in development investment (\$34.1 million in 2002 versus $\$ 81.2$ million in 2001). The $\$ 47.2$ million decrease in mineral development investment in 2002 was more than offset by the increased value of mineral products $(\$ 1,012.8$ million in 2002 compared with $\$ 917.3$ million in 2001). Alaska’s mineral production value was $\$ 1,012.8$ million, rebounding almost $\$ 100$ million from the 2001 value of $\$ 917$ million. Had the price of zinc not declined 12.5 percent from 2001 levels, the gross value of the mineral products would have been nearly $\$ 72$ million greater.

Exploration during 2002 occurred across most regions of the state, with almost half of the exploration funds spent in southwestern Alaska. More than \$17 million was spent exploring on gold and associated precious metal projects across the state. The decline in development investment mainly reflects completion of ongoing projects at Red Dog Mine in northern Alaska, but small projects were reported at the Fort Knox/True North complex, Usibelli Coal Mine, and Pogo in the interior, and at Kensington and Greens Creek mines in

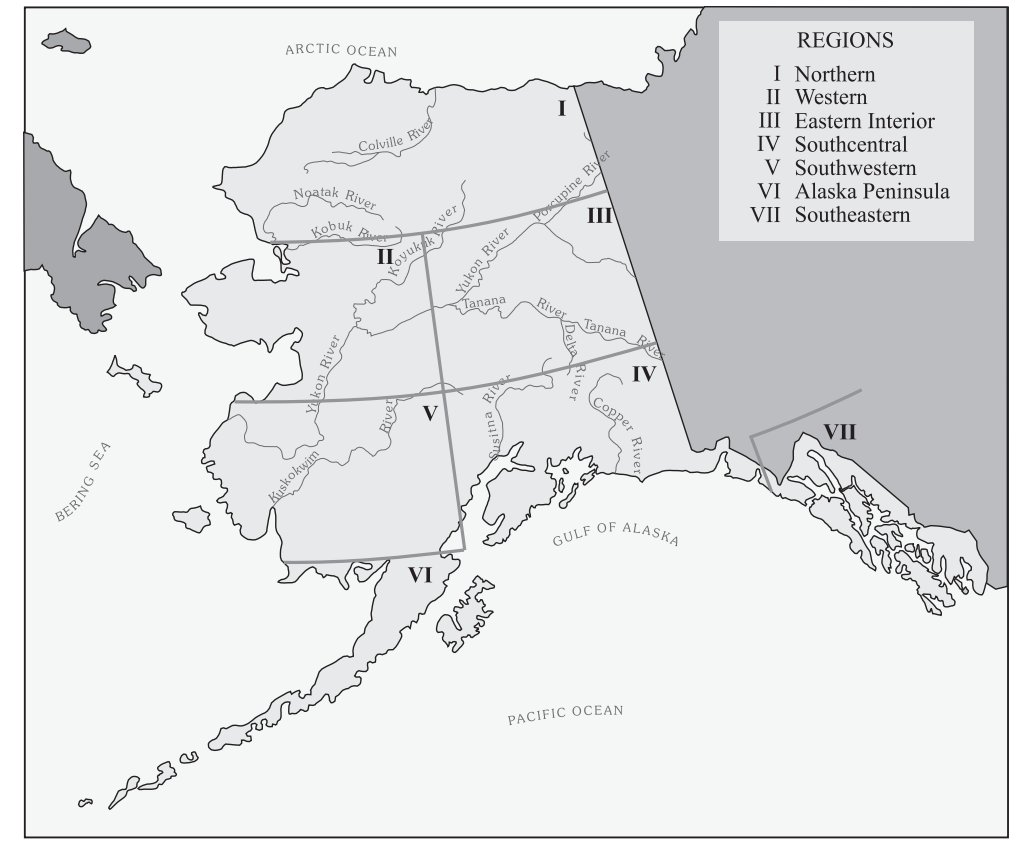

Figure 1. Regions of mineral activity in Alaska as described in this report.

\footnotetext{
${ }^{1}$ Alaska Division of Geological \& Geophysical Surveys, 3354 College Road, Fairbanks, Alaska 99709-3707 E-mail for D.J. Szumigala: zoom@dnr.state.ak.us

${ }^{2}$ Alaska Division of Community \& Business Development, Unit \#7, 3677 College Road, Fairbanks, Alaska 99709-3732

${ }^{3}$ Alaska Division of Mining, Land \& Water, 550 W. 7th Avenue, Suite 900B, Anchorage, Alaska 99501-3577

${ }^{4}$ Alaska Division of Community \& Business Development, PO Box 110809, Juneau, Alaska 99811-0809
} 
southeastern Alaska. Production at Greens Creek Mine reached record levels, and was robust at Fort Knox and Red Dog Mine. Placer gold production levels were comparable to those of the previous year, and are expected to increase in 2003 corresponding to the rising price of gold.

Table 1. Total value of the mineral industry in Alaska by year (in millions of dollars)

\begin{tabular}{lrrrr}
\hline & $\begin{array}{c}\text { Exploration } \\
\text { (expenditure) }\end{array}$ & $\begin{array}{c}\text { Development } \\
\text { (expenditure) }\end{array}$ & $\begin{array}{c}\text { Production } \\
\text { (value) }\end{array}$ & $\begin{array}{c}\text { Total } \\
\text { (calculated) }\end{array}$ \\
1981 & & & & \\
1982 & 76.3 & 24.7 & 188.6 & 289.6 \\
1983 & 45.6 & 41.6 & 196.4 & 283.7 \\
1984 & 34.1 & 27.9 & 212.4 & 274.4 \\
1985 & 22.3 & 53.4 & 199.4 & 275.1 \\
1986 & 9.2 & 34.1 & 226.6 & 269.9 \\
1987 & 8.9 & 24.3 & 198.5 & 231.7 \\
1988 & 15.7 & 100.3 & 202.4 & 318.4 \\
1989 & 45.5 & 275.0 & 232.2 & 552.6 \\
1990 & 47.8 & 134.3 & 277.0 & 459.0 \\
1991 & 63.3 & 14.3 & 533.0 & 610.6 \\
1992 & 39.9 & 25.6 & 546.5 & 612.0 \\
1993 & 30.2 & 29.6 & 560.8 & 620.6 \\
1994 & 30.3 & 27.7 & 448.7 & 506.7 \\
1995 & 31.1 & 45.0 & 507.5 & 583.6 \\
1996 & 34.3 & 148.6 & 537.2 & 720.1 \\
1997 & 44.7 & 394.0 & 590.4 & $1,029.2$ \\
1998 & 57.8 & 168.4 & 936.2 & $1,162.4$ \\
1999 & 57.3 & 55.4 & 921.2 & $1,033.9$ \\
2000 & 52.3 & 33.8 & $1,032.9$ & $1,119.0$ \\
2001 & 34.9 & 141.7 & $1,106.4$ & $1,283.0$ \\
2002 & 23.8 & 81.2 & 917.3 & $1,022.3$ \\
& 26.5 & 34.0 & $1,012.8$ & $1,073.3$ \\
TOTAL & $\$ \mathbf{\$ 8 3 1 . 8}$ & $\mathbf{\$ 1 9 1 4 . 9}$ & $\mathbf{\$ 1 1 , 5 8 4 . 4}$ & $\mathbf{\$ 1 4 , 3 3 1 . 1}$ \\
\hline
\end{tabular}

SouRCE: Alaska's mineral industry reports published annually by DGGS.
The total minerals industry employment in 2002 is estimated to be 2,824 full-time-equivalent jobs (table 2; fig.3), a drop of 11 jobs from the 2,835 reported in 2001. Most of the decline was in the development sector, counteracted to some extent by an increase in the lode gold mining and industrial minerals sectors.

\section{ACKNOWLEDGMENTS}

This report on the Alaska minerals industry is intended to provide current, accurate, and technically reliable information. The authors wish to thank all companies, agencies, and individuals that responded to the questionnaires or phone calls and provided information about their activities and operations. Without your voluntary and timely information this report would not be possible.

DGGS mailed 838 questionnaires in November 2002 and received 148 responses, 37 of which reported no mining activity. Dave Szumigala (DGGS) and Dick Swainbank (DCBD) prepared the body of the text, tables, and appendices with information supplied by many individuals and with the assistance of staff from other agencies. Where appropriate, these people have been acknowledged in the text.

The cover design is by Joni Robinson, and the graphic illustrations are by Fred Sturmann and Joni Robinson of DGGS. Paula Davis of DGGS edited the final version, and Joni Robinson completed the layout and design. Printing costs were paid by the Division of Community \& Business Development.

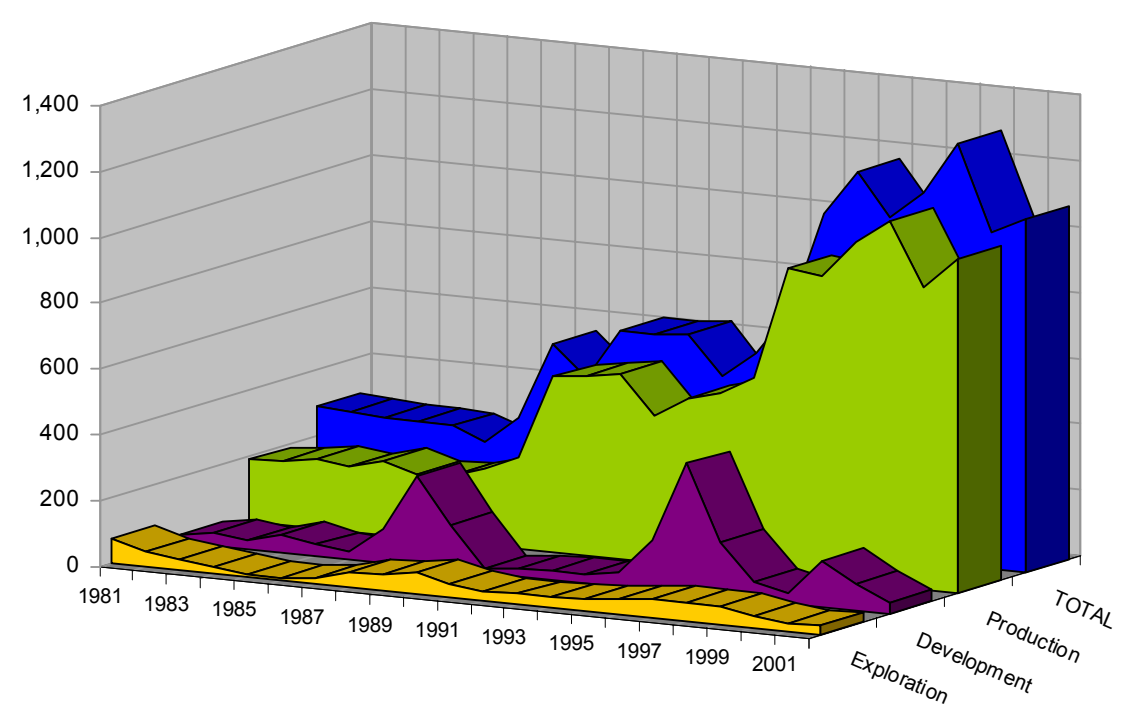

Figure 2. Alaska's mineral industry total value, 1981-2002. 
Table 2. Estimated Alaska mine employment, 1996-2002 ${ }^{a}$

\begin{tabular}{|c|c|c|c|c|c|c|c|}
\hline & 1996 & 1997 & 1998 & 1999 & 2000 & 2001 & 2002 \\
\hline \multicolumn{8}{|l|}{ Gold/silver mining } \\
\hline Placer & 825 & 780 & 710 & 591 & 470 & 176 & 148 \\
\hline Lode & 138 & 415 & 345 & 296 & 274 & 337 & 413 \\
\hline Polymetallic & 68 & 230 & 275 & 275 & 275 & 275 & 262 \\
\hline Base metals & 407 & 478 & 466 & 549 & 556 & 559 & 580 \\
\hline Recreational & 260 & 270 & 255 & 240 & 250 & 210 & 180 \\
\hline Sand \& gravel & 598 & 700 & 658 & 590 & 603 & 556 & 702 \\
\hline Rock & 149 & 123 & 121 & 128 & 150 & 137 & 177 \\
\hline Coal & 115 & 118 & 128 & 121 & 121 & 121 & 100 \\
\hline Peat & 38 & 42 & 40 & 38 & 36 & 32 & 21 \\
\hline $\begin{array}{l}\text { Tin, jade, soapstone, } \\
\text { ceramics, platinum }\end{array}$ & 20 & 20 & 20 & 20 & 20 & 20 & 20 \\
\hline Mineral development & 862 & 409 & 177 & 135 & 345 & 333 & 135 \\
\hline Mineral exploration & 257 & 277 & 282 & 183 & 83 & 79 & 86 \\
\hline TOTAL & 3,737 & 3,862 & 3,477 & 3,166 & 3,183 & 2,835 & 2,824 \\
\hline
\end{tabular}

${ }^{\mathrm{a} C}$ Calculated on a 260 -day work year.

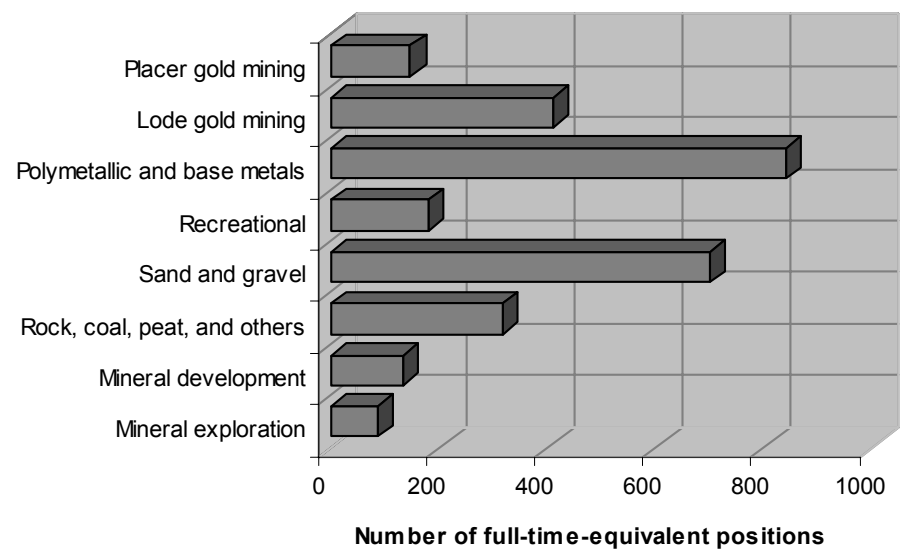

2002 Total: 2,824 full-time-equivalent jobs

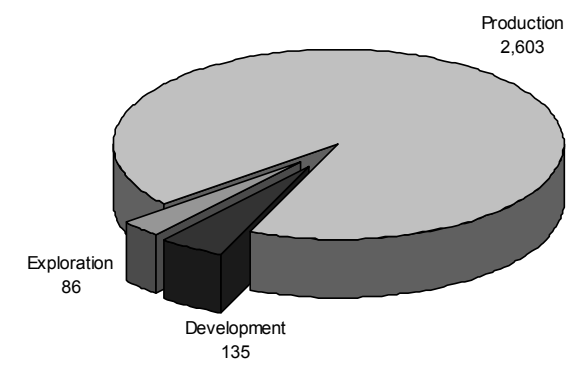

Figure 3. 2002 mineral industry employment by category.

\section{EXPLORATION}

Estimated exploration expenditures in Alaska during 2002 are about $\$ 26.5$ million, a $\$ 2.7$ million increase compared to expenditures of $\$ 23.8$ million in 2001. The value of mineral exploration is still low compared to spending levels in the late 1980s through late 1990s. Exploration expenditures and employment by region are detailed in table 3 . Exploration expenditures by commodity are listed in table 4 and shown in figure 4 . The locations of significant exploration projects in Alaska during 2001 are shown in figure 5. Exploration during 2002 occurred across most regions of the state, with the exception of the Alaska Peninsula area, in which there was no known mineral exploration. Several large projects accounted for most of the exploration expenditures and drill footage: Donlin Creek gold project (NovaGold Resources Inc.), Pebble copper-gold project
(Northern Dynasty Minerals Ltd.), Greens Creek mine exploration (Kennecott Minerals Co./Hecla Mining Co.), and Fairbanks mining district gold projects (Kinross Gold Corp.). Almost half of the 2002 Alaska exploration expenditures were spent in southwestern Alaska. The eastern interior region saw a sharp reduction in activity, while the Seward Peninsula experienced a rebirth in activity. Gold remained the major exploration commodity, with over $\$ 17$ million spent on exploration in 2002, but polymetallic exploration increased from recent levels. As in years past, most exploration funds, more than 72 percent, were derived from Canadian sources.

Table 5 summarizes the number of new and active (new plus existing) claims per year, from 1991 to 2002 . The table has been modified to show the number of 20 -acre federal 
Table 3. Reported exploration expenditures and employment in Alaska, 2002

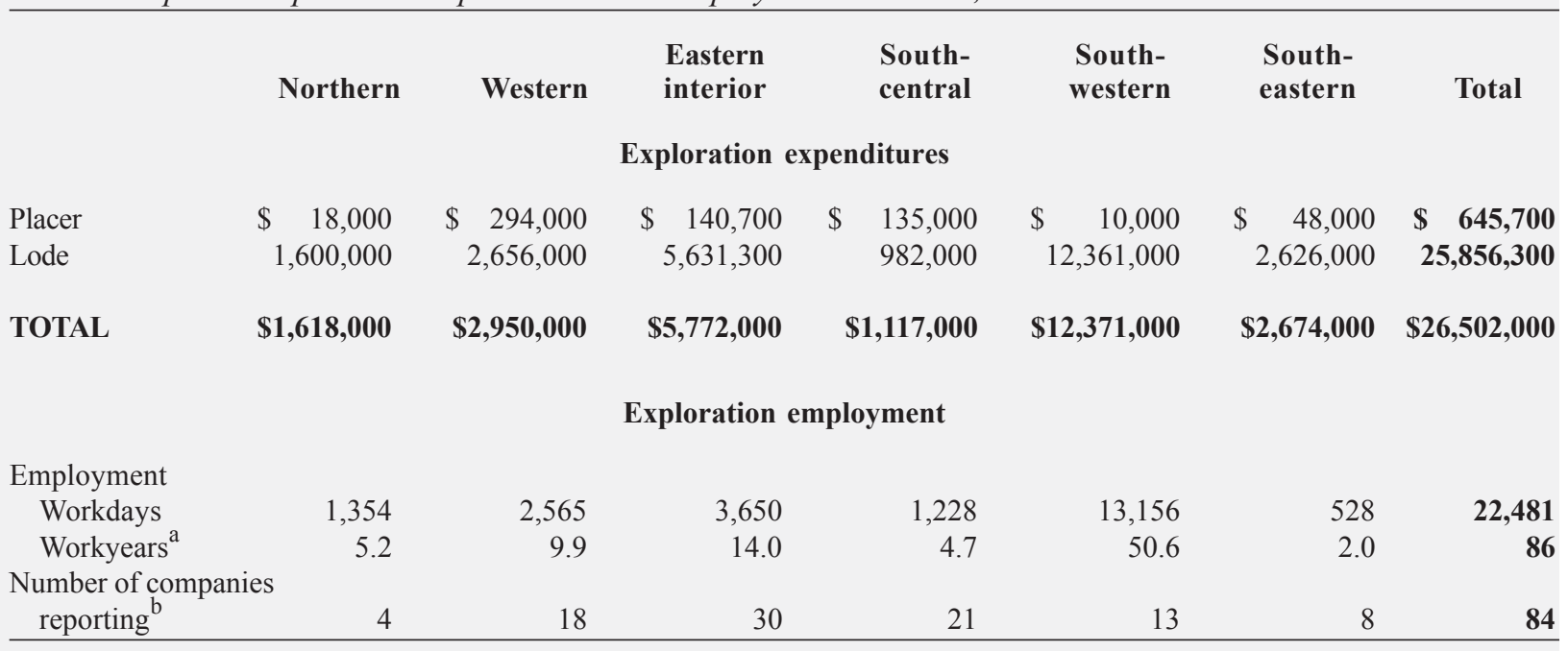

a Based on 260-day workyear.

bSome companies were active in several areas.

No exploration expenditures or employment reported for Alaska Peninsula in 2002.

Table 4. Reported exploration expenditures in Alaska by commodity, 1982-2002

\begin{tabular}{|c|c|c|c|c|c|c|c|}
\hline & $\begin{array}{c}\text { Base } \\
\text { metals }\end{array}$ & Polymetallic $^{a}$ & $\begin{array}{c}\text { Precious } \\
\text { metals }\end{array}$ & $\begin{array}{c}\text { Industrial } \\
\text { minerals }\end{array}$ & $\begin{array}{c}\text { Coal } \\
\text { and peat }\end{array}$ & Other $^{b}$ & Total \\
\hline 1982 & $\$ 31,757,900$ & N/A & $\$ 10,944,100$ & $\$ \quad--$ & $\$ 2,900,000$ & 15,300 & $\$ 45,617,300$ \\
\hline 1983 & $9,758,760$ & N/A & $20,897,555$ & $2,068,300$ & $1,338,454$ & 70,000 & $34,133,069$ \\
\hline 1984 & $4,720,596$ & $\mathrm{~N} / \mathrm{A}$ & $14,948,554$ & 270,000 & $2,065,000$ & 279,500 & $22,283,650$ \\
\hline 1985 & $2,397,600$ & N/A & $6,482,400$ & - - & 270,000 & - - & $9,150,000$ \\
\hline 1986 & $1,847,660$ & N/A & $6,107,084$ & 170,000 & 790,000 & - - & $8,914,744$ \\
\hline 1987 & $2,523,350$ & $\mathrm{~N} / \mathrm{A}$ & $11,743,711$ & 286,000 & $1,150,000$ & 31,000 & $15,734,061$ \\
\hline 1988 & $1,208,000$ & N/A & $41,370,600$ & 160,200 & $2,730,000$ & - - & $45,468,800$ \\
\hline 1989 & $3,503,000$ & N/A & $43,205,300$ & 125,000 & 924,296 & 5,000 & $47,762,596$ \\
\hline 1990 & $5,282,200$ & $\mathrm{~N} / \mathrm{A}$ & $57,185,394$ & 370,000 & 321,000 & 97,000 & $63,255,594$ \\
\hline 1991 & $4,789,500$ & N/A & $34,422,039$ & 92,000 & 603,000 & 2,000 & $39,908,539$ \\
\hline 1992 & $1,116,000$ & $3,560,000$ & $25,083,000$ & 25,000 & 425,000 & - - & $30,209,000$ \\
\hline 1993 & 910,000 & $5,676,743$ & $23,382,246$ & 163,500 & - - & 125,000 & $30,257,489$ \\
\hline 1994 & 600,000 & $8,099,054$ & $18,815,560$ & 225,000 & $2,554,000$ & 810,000 & $31,103,614$ \\
\hline 1995 & $2,770,000$ & $10,550,000$ & $20,883,100$ & 100,000 & - & 3,000 & $34,306,100$ \\
\hline 1996 & $1,100,000$ & $11,983,364$ & $31,238,600$ & 400,000 & - & - - & $44,721,964$ \\
\hline 1997 & $1,700,000$ & $22,347,000$ & $32,960,500$ & 80,000 & 720,000 & - & $\mathbf{5 7 , 8 0 7 , 5 0 0}$ \\
\hline 1998 & $1,000,000$ & $13,727,000$ & $42,441,000$ & 12,000 & 87,000 & - & $57,267,000$ \\
\hline 1999 & $3,869,000$ & $3,168,000$ & $44,891,000$ & 1,000 & - - & 410,000 & $52,339,000$ \\
\hline 2000 & $8,545,000$ & $3,933,000$ & $21,579,000$ & 58,500 & - - & 736,100 & $34,851,600$ \\
\hline 2001 & $4,810,000$ & $1,977,000$ & $15,820,000$ & 50,000 & 10,000 & $1,106,000$ & $23,773,000$ \\
\hline 2002 & $1,700,000$ & $5,162,000$ & $17,342,000^{\mathrm{c}}$ & 185,000 & - - & $2,113,000$ & $26,502,000$ \\
\hline TOTAL & $\$ 95,908,566$ & $\$ 90,183,161$ & $\$ 541,742,743$ & $\$ 4,841,500$ & $\$ 16,887,750$ & $\$ 5,802,900$ & $\$ 755,366,620$ \\
\hline
\end{tabular}

aPolymetallic deposits considered as a separate category for the first time in 1992.

bIncludes diamonds and tantalum.

${ }^{c}$ Approximately $\$ 650,000$ spent on platinum-group-element exploration during 2002.

$\mathrm{N} / \mathrm{A}=$ Not available.

- - Not reported. 


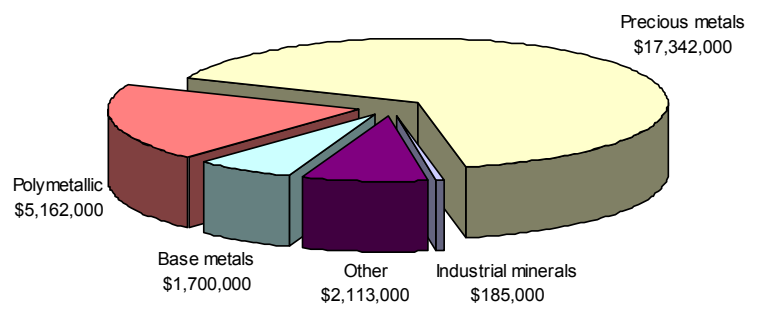

Figure 4. 2002 exploration expenditures by commodity.

mining claims, 160 -acre state prospecting sites, and 40 - or 160 -acre state mining claims. During 2002, 1,531 new state mining claims (158,320 acres), 57 new state prospecting sites ( 9,120 acres), and 261 new federal claims (5,220 acres) were staked. State claim staking increased from 2001 levels, while the number of new federal mining claims was the lowest in the past 10 years. The amount of land in Alaska under claim continues to drop from 1999 levels, with approximately 2.6 million acres of land covered by claims or prospecting sites in 2002. This is a drop of 7 percent from 2001 levels, and a 29 percent drop from the 3.7 million acres under claim in 1999.

\section{NORTHERN REGION}

Kennecott Exploration Co. planned to conduct mineral exploration, including core drilling, in the Wulik River area near the Lik camp. Previous work in this area during 2001 included collecting in excess of 500 geochemical samples, collecting gravity data from more than 1,500 sites, and mapping the geology of selected sites.

\section{WESTERN REGION}

The Seward Peninsula was the center of activity for the western region of Alaska. The major projects in the area are described below. Other exploration projects included work by Greatland Exploration Inc. on the Omalik property and some exploration at several placer gold properties.

NovaGold Resources Inc. and TNR Resources Ltd. finalized a joint-venture agreement to advance the million-ounce gold resource at the Rock Creek property near Nome toward production within the next 3 years. Under terms of the agreement TNR Resources would earn a 49.9 percent interest in the project by spending $\$ 10$ million on exploration and development to bring the project to production by June 2005. As part of the agreement, TNR Resources will issue 500,000 shares to NovaGold. NovaGold previously released a total Measured and Indicated Resource of 555,000 ounces grading 0.08 ounces per ton gold with an additional Inferred Resource of 303,000 ounces of gold grading 0.081 ounces per ton using a 0.029 ounces per ton cut-off grade, based on work completed by NovaGold, Kennecott, Newmont, and Placer Dome at Rock Creek. The adjacent Saddle deposit contains an additional Inferred Resource of 260,000 ounces of gold grading 0.076 ounces per ton gold using a 0.029 ounces per ton cut-off grade.

The 2002 drill and trench program at Rock Creek was designed to expand the extent of the known gold resource and to complete in-fill core drilling along the higher grade Albion Zone. The drill program consisted of 16 core holes totaling 3,878 feet that successfully intersected targeted shallow high-grade Albion zone and surrounding vein mineralization. Gold grades within these drill holes confirm previous results, and more closely spaced drilling should upgrade some resources to the higher measured and indicated categories. Drilling also extended the overall mineralized zone to longer than 1 mile in strike length. The system remains open along strike and down dip and excellent potential remains to continue to expand the higher grade Albion Zone, as well as to discover new zones with further drilling. Drill highlights from 2002 include: drill hole 101 with 111.6 feet grading 0.047 ounces per ton gold, including 6.6 feet at 0.5 ounces per ton; hole 102 with 200 feet grading 0.044 ounces per ton gold, including 13 feet at 0.15 ounces per ton gold; hole 105 with 288.7 feet grading 0.037 ounces per ton gold, including 32.8 feet at 0.16 ounces per ton gold; drill hole 115 where the entire 344.5 -foot hole averaged 0.025 ounces per ton gold and included 26.25 feet grading 0.103 ounces per ton gold with a separate interval of 39.4 feet grading 0.118 ounces per ton gold; and drill hole 116 with 380.6 feet grading 0.05 ounces per ton gold from top to bottom, including 52.5 feet grading 0.09 ounces per ton gold with a separate interval of 91.9 feet grading 0.134 ounces per ton gold.

Approximately 1,500 feet of trenching was completed on the Rock Creek project in 2002. Initial trenching on a broad gold-in-soil anomaly approximately 1,000 feet south of the modeled pit exposed a zone of stockwork veining and disseminated sulfide mineralization. High-grade gold mineralization, up to 39 feet of 0.15 ounces per ton gold, intercepted in trench RKT-104 is more than 400 feet southwest of the currently drilled resource. Also, sampling at the end of Trench RKT-111, more than 150 feet northeast of the modeled pit limit, showed highly anomalous gold and trace-element geochemistry consistent with peripheral Albion zone mineralization. Several other nearby soil anomalies also hold significant potential for similar styles of mineralization and will be targeted for work in 2003.

Navigator Exploration Corp. and Chapleau Resources Ltd. planned a minimum $\$ 600,000$ drilling program on the Kougarok tantalum-tin prospect in the north-central Seward Peninsula, approximately 67 miles north of Nome, Alaska. The Kougarok property appears to be underlain by a large, multiphase intrusion that incorporates a number of mineralized cupolas formed by tantalum-enriched albitezinnwaldite granites. Numerous significant drill intercepts of tin and tantalum mineralization in previous work (early 1980s) were encountered from a cupola known as the "main 
plug." Surface exploration undertaken by Navigator and Chapleau during 2001 identified new showings at the Hill Top and Real Top prospects elsewhere on the property that were incorporated into the 2002 drilling program.

Five geographically distinct target areas were selected for the 2002 Kougarok work program to test geologic models, evaluate newly discovered mineral showings, and confirm tantalum values reported by Anaconda. In excess of 500 rock samples were collected during a property-wide prospecting program that ran concurrently with the 2002 drilling. Analytical results pertaining to these samples were not released. Approximately 8,000 feet of drilling was completed in seven vertical holes and a total of 259 samples were split for analysis. The holes were collared over an area of about 2 square miles with distances between holes ranging from 700 feet to more than a mile. Each hole encountered anomalous tantalum values at the hanging wall contact (that is, upper surface) of the targeted zinnwaldite granite. Only hole 2002-04, located on the previously un- tested eastern margin of the main plug, returned potentially economic values of tantalum. Zinnwaldite granite related to the main plug was intercepted between 429 and 1,003 feet. The best intercept within this interval was 347.5 feet grading 0.017 percent tantalum $\left(0.021\right.$ percent $\left.\mathrm{Ta}_{2} \mathrm{O}_{5}\right)$ from 443 to 791 feet, including 184 feet grading 0.021 percent tantalum $\left(0.026\right.$ percent $\left.\mathrm{Ta}_{2} \mathrm{O}_{5}\right)$ from 585.7 to 769 feet and 103 feet grading 0.023 percent tantalum $(0.029$ percent $\mathrm{Ta}_{2} \mathrm{O}_{5}$ ) from 585.7 to 689 feet. The program confirmed the presence of a large, well-preserved, tantalum-bearing granitic system. Given current tantalum prices, however, the economic potential of the deposit appears limited at this time.

Quaterra Resources Inc. drill tested three road-accessible projects on the Seward Peninsula with drill targets established by coincident gravity and geochemical anomalies. The four diamond drill holes on the properties failed to intercept mineralization. As a result, Quaterra relinquished rights to the Think Zinc, Sinuk River, and Rocky Mountain

\section{Northern Region}

1. Wulik River area-Kennecott Exploration Co.

\section{Western Region}

2. Rock Creek-TNR Resources Ltd./NovaGold Resources Inc.

3. Kougarok-Navigator Exploration Corp./ Chapleau Resources Ltd.

4. Think Zinc/Rocky Mountain Creek/Sinuk River-Quaterra Resources Inc.

5. Divide-Rio Fortuna Exploration Corp.

6. Tolstoi/Boob Creek-3D Mining Inc./ Northern Associates Inc.

\section{Eastern Interior Region}

7. Fairbanks district

a. Fort Knox-True North-Kinross Gold Corp.

b. Gil claims - Kinross Gold Corp./Teryl Resource Corp.

c. General-Kinross Gold Corp.

d. Golden Summit-Freegold Ventures Ltd.

8. Pogo-Goodpaster mining district

a. Gobi-Portal-AngloGold (USA) Exploration Inc./Continental Ridge Resources Inc.

b. Eagle-Ogo-Fire-AngloGold (USA) Exploration Inc./ Rimfire Minerals Corp.

c. Rob-Freegold Ventures Ltd.

9. Richardson district-Polar Consulting and Exploration Inc., Tri-Valley Corp.

10. Road Metal-North Star Exploration Inc.

\section{Southcentral Region}

11. MAN_-Nevada Star Resource Corp.

12. Shulin Lake-Golconda Resources Ltd./Shulin Lake Mining Inc./Shear Minerals Ltd.

13. Forbes-Emerick - Northridge Exploration

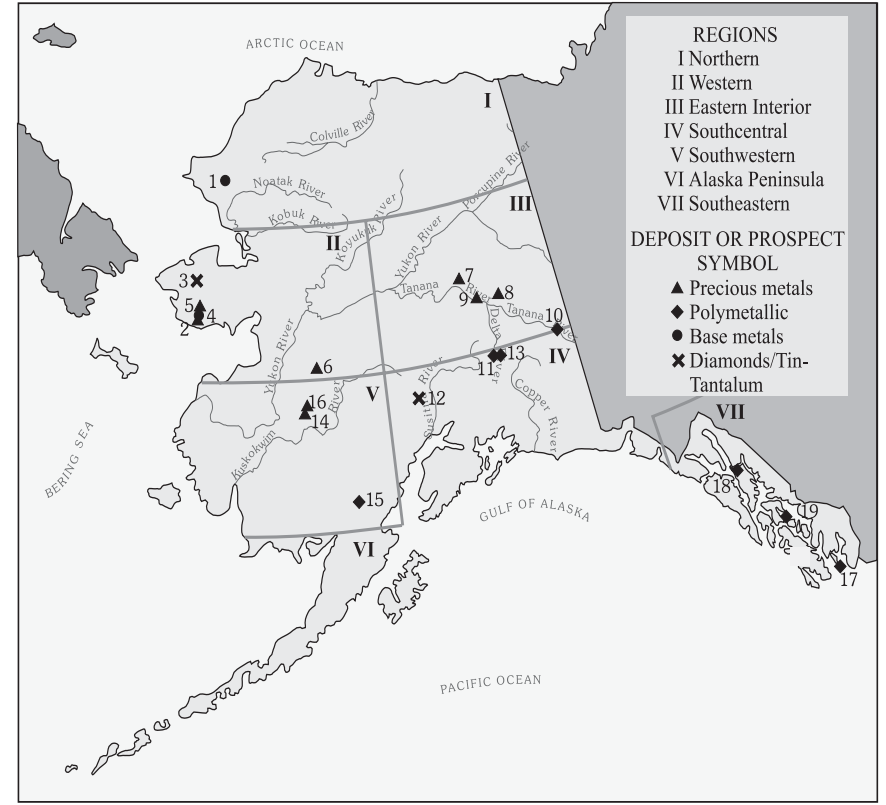

V Southwestern Region

14. Donlin Creek-NovaGold Resources Inc.

15. Pebble-Northern Dynasty Minerals Ltd./Hunter Dickinson Group Inc.

16. Donlin Creek North - Ventures Resource Corp. Ada-Ventures Resource Corp.

\section{Alaska Peninsula Region}

VII Southeastern Region

17. Duke Island-Quaterra Resources Inc.

18. Greens Creek-Kennecott Minerals Co./Hecla Mining Co.

19. Woewodski Island-Olympic Resources Group LLC

Figure 5. Selected exploration projects in Alaska, 2002. 
Table 5. Summary of claim activity by acres, 1991-2002

\begin{tabular}{|c|c|c|c|c|c|c|c|c|}
\hline \multirow{3}{*}{ Year } & \multicolumn{4}{|c|}{ State Claims } & \multicolumn{2}{|c|}{ State Prospecting Sites } & \multicolumn{2}{|c|}{ Federal Claims } \\
\hline & New & New & $\begin{array}{c}\text { Total } \\
\text { (Active) }\end{array}$ & $\begin{array}{c}\text { Total } \\
\text { (Active) }\end{array}$ & New & $\begin{array}{c}\text { Total } \\
\text { (Active) }\end{array}$ & New & $\begin{array}{c}\text { Total } \\
\text { (Active) }\end{array}$ \\
\hline & 40 acre & 160 acre & 40 acre & 160 acre & & & & \\
\hline 1991 & 3,277 & 0 & 38,485 & 0 & 747 & 1,735 & 1,299 & 23,222 \\
\hline 1992 & 2,650 & 0 & 36,947 & 0 & 454 & 1,490 & 695 & 20,254 \\
\hline 1993 & 2,110 & 0 & 34,908 & 0 & 1,412 & 2,281 & 601 & 9,298 \\
\hline 1994 & 4,064 & 0 & 35,184 & 0 & 810 & 2,449 & 341 & 8,495 \\
\hline 1995 & 4,508 & 0 & 31,796 & 0 & 1,030 & 2,850 & 376 & 7,766 \\
\hline 1996 & 9,495 & 0 & 37,843 & 0 & 2,082 & 3,735 & 681 & 9,346 \\
\hline 1997 & 8,671 & 0 & 43,968 & 0 & 2,480 & 5,334 & 1,872 & 11,320 \\
\hline 1998 & 9,786 & 0 & 50,464 & 0 & 3,187 & 7,278 & 427 & 11,033 \\
\hline 1999 & 11,977 & 0 & 56,673 & 0 & 1,740 & 7,639 & 308 & 10,176 \\
\hline 2000 & 4,472 & 614 & 54,369 & 614 & 1,077 & 5,641 & 523 & 7,805 \\
\hline 2001 & 620 & 760 & 48,923 & 1,372 & 8 & 3,043 & 464 & 8,248 \\
\hline 2002 & 722 & 809 & 43,989 & 2,329 & 57 & 2,141 & 261 & 8,100 \\
\hline
\end{tabular}

Federal claims $=20$ acres, State claims $=40$ acres or 160 acres, State prospecting sites $=160$ acres.

Information provided by Jack Davis (Land Records Information Section, DNR) and Evvie Garis (USBLM). Table has been reorganized to conform with computer records available after 1990.

Creek projects. Quaterra retained the 100-percent-owned Big Bar prospect.

On the Sinuk River prospect, a prominent egg-shaped 1.0 milligal gravity anomaly covering a 1,200 -foot by 600 foot area and occurring at a depth of about 200 feet below the surface was tested with one vertical core hole. A basalt flow intersected in the drilling accounts for the gravity anomaly. At the Rocky Mountain Creek property, a broad, open-ended gravity anomaly appears to be cut into two blocks by a previously mapped left-lateral fault. The 0.7 milligal anomaly occurs at an estimated 200-300 feet below the surface and appears to be gently dipping to the west. The eastern margin of the zone correlates with outcropping massive-sulfide mineralization in at least three places. A drillhole into the zone intersected an exhalative horizon but did not encounter any massive-sulfide mineralization. Two holes, each 400 feet deep, were drilled at the Think Zinc property to test two gravity anomalies that are coincident with multi-element mobile metal ion anomalies. A monotonous schist sequence was encountered in both drill holes and the gravity anomalies remain unexplained. During 2002, reconnaissance of the Big Bar prospect area identified several localities for a possible airstrip to be used during a proposed 2003 drilling program.

Rio Fortuna Exploration Corp. acquired the road-accessible Divide Project 28 miles north of Nome. Rio Fortuna may earn a 100 percent interest in the property by making cash payments totaling $\$ 1$ million over a 5 -year period and issuing 1 million shares of Rio Fortuna common stock. The property will be subject to a sliding scale net smelter royalty ranging from 2 percent at a gold price of $\$ 300$ or less per ounce to 5 percent at a gold price of $\$ 500$ or more per ounce. A large, 0.029 ounces per ton gold-in-soil anomaly lies within the northeastern sector of a larger 8,000 feet by 4,500 feet gold-in-soil anomaly that averages greater than 0.003 ounces per ton. Rio Fortuna drilled 18 holes, totaling 4,452 feet, from eight drill pads to test flat-lying quartzalbite-arsenopyrite veins and silicified zones within a graphitic schist horizon over a strike length of 1,500 feet by 1,000 feet. Silicification was traced through nine out of eleven drill holes. Hole 02RF-5 intersected 39 feet of 0.048 ounces per ton gold. Other gold values in drill samples ranged from 0.007 ounces per ton up to 0.181 ounces per ton in 14 of 18 drill holes. Sample widths ranged from a minimum 6.5 feet to 52 feet.

Rio Fortuna also completed a first phase reconnaissance program on the 24-square-mile Full Auto project, which also is road accessible, 12 miles northwest of Nome. A total of 560 stream sediment, soil, and rock samples have been collected from this area, which is unexplored for lode resources but which has seen placer development on four creeks during the early 1900s. Gold placer concentrates from Hungry Creek contained native bismuth nuggets while it has been reported that gold-bearing native bismuth and scheelite in placer gold concentrates have been found at Nugget Gulch and Oregon Creek.

Altar Resources and subsidiary Royal Pretoria Gold Ltd. continued exploration on gold prospects not joint ventured with other companies. Altar Resources further sampled the "Dripping gold zone" on the Bulk Gold property in 2002. Soil samples ranged up to 0.016 ounces of gold per ton and greater than 1 percent arsenic. A float sample of silicified, arsenopyrite-bearing carbonate from near the highest-grade soil sample contained 0.06 ounces of gold per ton. 
3D Mining Inc., with contractor Northern Associates Inc. (NAI), continued some exploration work while placer mining on the Tolstoi (gold-platinum) project in the Mt. Hurst-Boob Creek area northwest of McGrath. At Boob Creek, in the southern part of the property, mineralogical evidence indicates that proximal sources for gold and platinum are being actively eroded to produce the metals recovered during placer mining. Much prospective ground for lode platinum and gold mineralization remains untested.

Exploration for placer gold and platinum was conducted on Boob Creek in the Tolstoi mining district with test placer cuts through 20 to 35 feet of overburden. Most work on the Tolstoi property and Boob Creek was to test the placer potential of gravels beneath approximately 20 to 35 feet of overburden. Placer gold recovered from a test pit measuring 30 feet by 150 feet by 150 feet exhibited highly variable forms from wires to well-rounded grains. The PGE:Au (platinum-group elements to gold) ratio is approximately 1:100 for placer mineralization. Pyrite recovered in the placer concentrates occurs as rounded balls to crystal fragments and as disseminated grains and veins in the underlying, partially silicified mudstone bedrock. A sample of pyrite from placer concentrates assayed 0.90 ounces per ton gold, 0.10 percent arsenic, 0.06 percent copper, and trace amounts of mercury.

\section{EASTERN INTERIOR REGION}

The Alaska Division of Geological \& Geophysical Surveys (DGGS) conducted a detailed geologic mapping project in the Salcha River-Pogo (SRP) geophysical tract within the Big Delta Quadrangle. Geologic mapping and geochemical sampling were conducted in a 60-day program stretching from the Salcha River near Caribou Creek to the Goodpaster River drainage near the Pogo gold property (fig. 6).

Kinross Gold Corp. continued exploration in the Fairbanks mining district with extensive drilling around the True North gold deposit. A mix of diamond and reversecirculation drilling at True North continued throughout the year to focus on the conversion of resources to reserves and to outline the limits of mineralization. An aggressive drill-based exploration program was conducted at the Fort Knox pit and surrounding area. In-pit drilling results include 75 feet grading 0.057 ounces per ton gold from the North Wall pushback, 85 feet grading 0.064 ounces per ton gold from the South Wall pushback, and 45 feet grading 0.186 ounces per ton gold from the South Wall pushback. Several drill holes had 5-foot intercepts with grades greater than 1 ounce per ton gold. Kinross also planned to con-

Figure 6. Jen Athey, geologist with the Alaska Division of Geological \& Geophysical Surveys, traverses through a chromite-bearing harzburgite and dunite ultramafic unit on Nail Ridge in the Salcha River-Pogo project area. Photo by Melanie Werdon. duct a 6,000 - to 8,000 -foot, reverse-circulation drill program on the leased Steamboat Creek property. Drilling was planned in the Zone 19, Birch \& Anderson, Cabin Creek, and South Ridge areas.

No exploration work was conducted on the Pogo property in 2002. However, Teck Cominco's Pogo gold project in Interior Alaska received its Preliminary Environmental Impact Statement (EIS) from the U.S. Environmental Protection Agency (EPA) and public review is anticipated in early 2003. The EPA draft EIS should be followed by a 60 day public comment period. The State Department of Natural Resources will release its recommendations as an attachment to the draft EIS. Teck completed permitting, condemnation and infill drilling, and feasibility studies during 2002. The company drilled more than 30,000 feet of core as part of an infill- and condemnation-drilling program. If permitting proceeds on schedule, construction may begin by late 2003 .

AngloGold (USA) Exploration Inc. conducted a threehole, 3,569-foot diamond-drilling program on Continental Ridge Resources Inc.'s 351-claim Gobi-Portal property, located 3 miles west of the Pogo deposit owned by Teck Cominco and Sumitomo Metals (fig. 7). AngloGold can earn a 60 percent interest in the Gobi-Portal property from Continental Ridge by making certain cash payments and spending $\$ 750,000$ on exploration over a 5 -year period. Drilling at the Hook target intersected a 330-foot-wide zone of gold mineralization hosted by granodiorite intrusive rocks near their contact with surrounding gneissic metamorphic rocks. Gold occurs in quartz veinlets with occasional calcite, tourmaline, pyrite, and arsenopyrite. Multiple sericite-altered, quartz-veined zones were intersected in hole AGGP-1. The

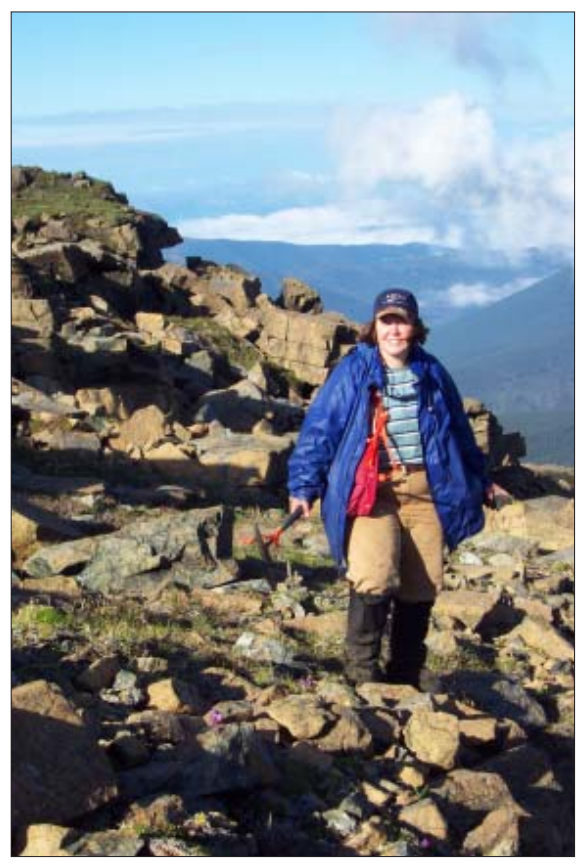


best assay results returned 0.031 ounces per ton gold over 10 feet, including 0.153 ounces per ton gold over 1.6 feet. Additional drilling is planned for 2003 .

AngloGold also signed two option agreements with Rimfire Minerals Corp. to earn up to a 70 percent interest in the Eagle and ER-Ogo-Fire properties. Initially, AngloGold may earn a 50 percent interest in the properties by making exploration expenditures totaling $\$ 400,000$ per property and paying Rimfire $\$ 100,000$ per property in staged cash payments over 4 years. AngloGold may increase its interest in the properties to 70 percent by incurring an additional $\$ 500,000$ in exploration expenditures per property. AngloGold conducted sampling and reconnaissance exploration, including soil auger and rock sampling programs on the properties. A gold-in-soil anomaly, coincident with elevated arsenic, bismuth, and antimony levels, covers a 5,000 -foot by 1,000 -foot area. An orientation soil auger program was also completed on the Eagle property over the intrusion-gneiss contact east of a grid sampled in 1999. AngloGold North America Inc. also signed an agreement with Zeus Exploration Inc. to earn a 65 percent vested interest in Zeus's West Pogo properties.

North Star Exploration Inc. continued a large exploration program, including drilling, at the Road Metal property near Northway. Tri-Valley Corp. continued gold exploration in the Richardson district. Polar Consulting and Exploration Inc. explored for the lode source of gold that produced placer gold previously mined by Polar Mining Inc. on a ridge between Buckeye and Tenderfoot creeks in the Richardson mining district. Silverado Mines Inc. conducted geochemical and geophysical surveys on the Ester Dome and Marshall Dome properties near Fairbanks.

Freegold Ventures Ltd. (Freegold), formerly International Freegold Mineral Development Inc., acquired the Rob gold project in the Goodpaster mining district, Alaska, a high-grade gold prospect about 20 miles southeast of the Pogo deposit. Freegold has an option to acquire a 100 percent interest in the property subject to payments totaling $\$ 29,000$ in cash over 7 years, plus payment of 500,000 shares prior to July 2003 and an additional 500,000 shares once Freegold has spent $\$ 1$ million on exploration. The property is also subject to a 1 percent net smelter return royalty. The Rob property is cut by a series of early $\mathrm{N} 50^{\circ} \mathrm{E}-$ trending high-angle structures (Double Bear, Gray Lead, and Black Mountain faults) that are cut by younger eastwest-trending high-angle structures (such as the Wolverine fault). Most previously discovered precious-metal veins on the property trend parallel to $\mathrm{N} 50^{\circ} \mathrm{E}$-trending structures in areas where Cretaceous granitic bodies are present. Limited sampling by Freegold in 2002 returned good results. Gold mineralization at both the Gray Lead and Hilltop prospects is controlled by the northeast-striking Gray Lead fault, which cuts sericite-altered Cretaceous granitic rocks and Paleozoic biotite gneiss. Mineralization is hosted in quartz veins and stockworks containing gold, arsenopyrite, bismuthinite, and an unknown tellurium-bearing mineral. Gold (up to 2.1 ounces per ton) is associated with highly anomalous arsenic (up to 10,000 parts per million), bismuth (up to 1,610 parts per million), and tellurium (up to 180 parts per million) and locally with elevated antimony (up to 1,000 parts per million) and tungsten (up to 495 parts per million). Mineralization on the Michigan, Upper-Lower Trench and O'Reely prospects is hosted in sericite-altered Cretaceous granitic rocks and Paleozoic biotite gneiss. Mineralization at these prospects is hosted in quartz veins, stockworks, and quartz breccias containing visible gold (up to 20.4 ounces per ton) with highly anomalous arsenic (up to 1 percent), antimony (up to 0.1 percent) and lesser bismuth (up to 39 parts per million). Gold mineralization on these prospects does not appear to be associated with elevated bismuth, tellurium, or tungsten, suggesting a genetically different style of mineralization from that seen on the Gray Lead prospect. Coarse visible gold was identified at surface on the Michigan lode and returned values up to 20 ounces gold per ton. This part of the Rob prospect has never been drilled. A single grab sample from unsplit diamond drill core from the Lower Trench prospect returned 0.12 ounces per ton gold from strongly quartz-sericitealtered granitic rock. The extent of this mineralization is unknown.

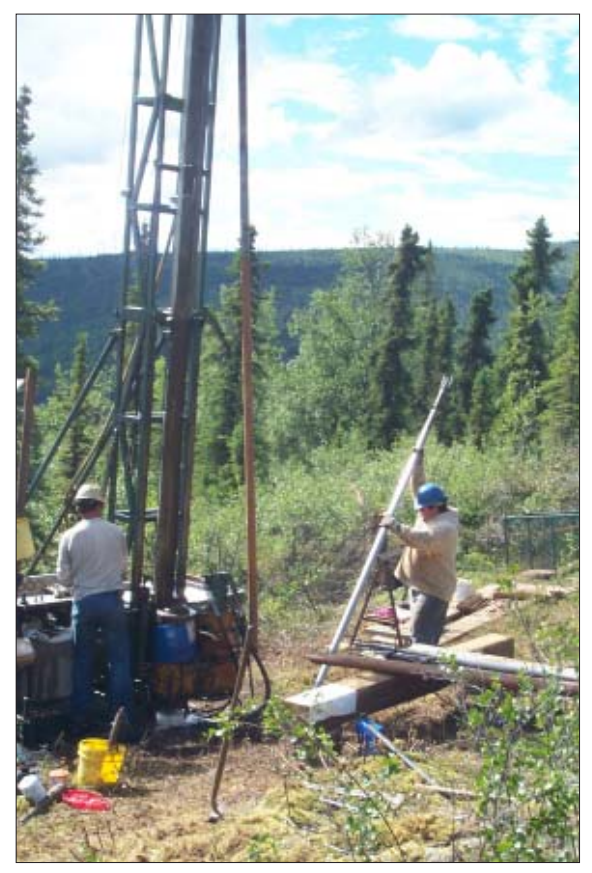

Figure 7. Core drilling at the Hook Target on the Gobi-Portal property, Goodpaster River area, eastern Interior region. Exploration during 2002 on this intrusion-hosted gold prospect was funded by AngloGold (USA) Exploration Inc., in a joint venture with Continental Ridge Resources Inc. Photo by David Szumigala. 
Freegold also conducted an exploration program on the Golden Summit property on Cleary Summit in the Fairbanks mining district. Freegold conducted a resistivity survey over the Currey Zone and then dug trenches based on interpretation of the geophysics and previous geochemical sampling. Grab samples of quartz vein material in the trenches returned values up to 6.167 ounces per ton gold while channel sample values ranged up to 10 feet grading 0.125 ounces per ton and 29 feet grading 0.034 ounces per ton. One 5 -foot channel sample assayed 0.337 ounces per ton gold. Approximately 100 feet of new backhoe trenching was conducted in a second phase and approximately 30 new channel and grab samples were collected. A trench extension exposed additional mineralization including an 18-inch-thick polyphase quartz vein that contained abundant coarse, visible gold (disseminated and leaf) with assays grading up to 12.5 ounces per ton gold. Grab sample geochemical results ranged from 0.127 to 12.5 ounces per ton gold, with five grab samples containing in excess of 1 ounce per ton gold.

Freegold's Currey Zone trenching program was designed to confirm hole CHD00-1 (64 feet grading 0.138 ounces per ton gold) and to test for continuity of mineralization along strike. The trenching program confirmed that hole CHD00-1 intersected a major system of veins and shear zones carrying significant gold values, the multi vein/shear zone system extends laterally with significantly mineralized widths similar to CHD00-1, and the mineralization "packet" is exposed at surface and is open along strike. Gold mineralization is associated with quartz, quartz-carbonate or quartz-sulfide-bearing veins and with shear zones where quartz volume is relatively low. Most of the mineralized structures mapped in the trenches trend $\mathrm{N} 60^{\circ}-$ $80^{\circ} \mathrm{W}$ and dip steeply south. These structures range from quartz veins with no apparent wall rock alteration or shearing to iron oxide-stained, schist-hosted breccia and shear zones up to 100 feet in width containing 1 to 20 percent crushed quartz in pods and veinlets. Bedrock hosting the mineralization consists of highly oxidized quartzite, quartz mica schist, chlorite schist and local actinolite schist cut by quartz, quartz-carbonate and quartz-carbonate-sulfide veins ranging from 1 inch to 25 inches thick. High-grade gold mineralization is associated with elevated arsenic and with sporadic anomalous silver, lead, bismuth, antimony, and tungsten. Based on these results, Freegold intends to carry out a step-out drilling program, possibly 4,000 feet of diamond core drilling in 8 to 10 holes, from the site of drillhole CHD00-1 during the 2003 winter.

In addition to the above exploration programs, Freegold also entered into an agreement with Anglo Alaska Gold Corp. whereby Freegold may earn a 100 percent interest in the Yeager Property adjacent the Golden Summit Property. The acquisition of the Yeager Property increases the Golden Summit land block to approximately 18,000 acres.
Teryl Resources Corp., with Kinross Gold Corp., announced encouraging drilling and surface exploration results at the Gil joint venture property in the Fairbanks mining district. Teryl Resources owns a 20 percent working interest and Kinross Gold owns an 80 percent working interest in the Gil joint venture property. Infill drilling on the Main Gil deposit area at hole GVC02-264 intercepted 220 feet of gold mineralization including 80 feet of 0.06 ounces per ton gold from 20- to 100-foot depth. Infill drilling at the North Gil deposit area succeeded with thick intercepts of significant gold grades in the southwestern portion of the North Gil resource area where previous drilling has been limited. Drillhole GVC02-262 intercepted 15 feet of 0.095 ounces per ton gold at depths from 65 to 80 feet and 10 feet of 0.087 ounces per ton gold from 200 to 210 feet, and drillhole GVC02-263 with four mineralized zones from 5 to 55 feet thick from 75 - to 975 -foot depths ranging from 0.040 to 0.105 ounces per ton gold. At the Slippery Creek prospect, drillhole GVC02-266 intersected 20 feet of 0.078 ounces per ton gold from 20 - to 40 -foot depth. A new zone of mineralization was intercepted in the Sourdough Ridge prospect in drillhole GVC02-267 and consists of 15 feet (from 95- to 110-foot depth) of 0.49 ounces per ton gold, including a 5 foot section of 1.34 ounces of gold per ton with anomalous arsenic and bismuth. Mineralization is hosted at the contact between overlying but barren calc-silicate-altered metamorphic rocks in thrust contact with underlying sericite-altered muscovite schist. The high-grade ore zone is hypothesized to be located where an east-west-trending high-angle structure intersects the favorable thrust horizon. Drilling completed this year and in previous years suggests mineralization continues to the northeast, according to consultant Avalon Development. Kinross Gold and Teryl plan additional work in 2003. Teryl Resources Corp. also planned to conduct an exploration and drilling program in early January 2003 on its 100-percent-owned Westridge property and its 50 percent option from Linux Wizardry Systems, Inc. on the Fish Creek property, both in the Fairbanks district.

Our Creek Mining Inc. conducted exploration on their Our Creek gold property, on Old Murphy Dome Road west of the Elliot Highway. The company staked prospecting sites in the North Ridge area including portions of the Old Dog prospect, sampled the Pingo prospect and found porphyritic rock in soil pits along strike of a porphyry dike system with a nearby soil sample assay of 0.014 ounces per ton gold, continued limited geological investigation across the Our Creek holdings, and applied for exploration permits to trench and drill a 4,000-foot-long arsenic-gold soil anomaly at the Line 18 prospect area.

Lockray Mining LLC planned to drill a reverse-circulation drill hole on the Bear Creek Ridge road in the Cleary Summit area of the Fairbanks mining district. No results have been announced. Mines Trust Co., in association 
with Piper Capital Inc., continued work on the Golden Zone property, with planned exploration to include trenching and drilling at the Copper King and Long Creek prospects. TriValley Corp. and TsNIGRI announced plans to form a joint stock company to be named Troika Mining Ventures Inc. The new company would pursue high-grade mining opportunities worldwide and one or more of TriValley's Richardson district properties may be included in the new company.

\section{SOUTHCENTRAL REGION}

Nevada Star Resource Corp. continued fieldwork during 2002 at its MAN nickel-copper-platinum-group-element (PGE) project near Tangle Lakes and the Denali Highway. Mapping, prospecting, and geochemical sampling were completed over a number of targets in the MAN Project area, including Canwell, East Rainy, Gezzi, Specimen Creek, Broxson Gulch and Bird's Beak. Detailed prospecting, mapping and sampling were also carried out in the area of the West Ridge, Middle Ridge and Odie showing areas. Additionally, three-dimensional modeling of Hummingbird ${ }^{\circledR}$ magnetic data from the Dunite Hill area, combined with geophysical results from the USGS and BLM, resulted in a more comprehensive interpretation of the geology and mineral potential of this high priority target area. Nevada Star is using an exploration model based on Noril'sk-style mineralization.

Nevada Star completed a helicopter-supported drill program on the Canwell portion of the MAN area, to test a linear zone of surface showings known as the West Ridge area (fig. 8). Here, disseminated to net textured sulfides occur in what is believed to be a tabular zone within a gabbroic border phase of a dunite intrusion. The semimassive to massive sulfide mineralization varies from 0.5 feet to 6 feet thick and is discontinuously exposed along a strike length of approximately 750 feet. Best results from float, grab, and chip samples ranged from 0.11 to 13.68 percent nickel, 0.12 to 4.51 percent copper, 0.001 to 0.147 ounces per ton gold, 0.001 to 0.590 ounces per ton platinum, and 0.008 to 0.500 ounces per ton palladium. Platinum values are greater than palladium values in most of the higher-grade samples. Grab samples of this mineralization contained up to 8.56 percent nickel, 0.86 percent copper, 0.058 ounces of platinum per ton, and 0.098 ounces of palladium per ton.

Highlights from the 2002 drilling program of 958 feet of core drilling in 7 holes on the MAN property include: hole 02-01 in the West Ridge area with 12 feet of mineralization from 5.4 to 17.4 foot depth, containing 0.56 percent nickel, 0.50 percent copper, 0.012 ounces of platinum per ton, and 0.012 ounces of palladium per ton; hole $02-03$ in the West Ridge area with 14 feet of mineralization from 5.0 to 19.0 foot depth, containing 0.63 percent nickel, 0.33 percent copper, 0.018 ounces platinum per ton, and 0.019 ounces palladium per ton; and hole 02-06 at the Odie prospect with 12 feet of mineralization from 398 to 410 foot depth, containing 0.56 percent nickel, 0.15 percent copper, 0.003 ounces platinum per ton, and 0.004 ounces palladium per ton. Only three of the seven holes reached target depth. During the drill program, Nevada Star discovered a massive-sulfide occurrence approximately 650 feet along strike from the West Ridge area. A grab sample of this material assayed 13.68 percent nickel, 2.9 percent copper, 0.59 ounces of platinum per ton, 0.26 ounces of palladium per ton and 0.149 ounces of gold per ton. The massive material was observed along a strike length of approximately 65 feet and has a thickness of up to 1 foot, as indicated by slumped massive-sulfide rubble outcrop.

A second zone of mineralization on the Canwell property, Odie, is approximately 1 mile along strike to the northwest from the West Ridge zone. Surface sampling results from the 2002 Nevada Star program at the Odie zone gave 1.25 percent nickel, 0.43 percent copper, 0.004 ounces of platinum per ton, and 0.018 ounces of palladium per ton over a 10-foot-long chip sample. One of two holes drilled at Odie (Hole 02-06) reached the target zone.

An intensive program of mapping, prospecting, and geochemical sampling also focused on the northern or Eureka Block of Nevada Star's 117-square-mile property. Several new nickel-PGE showings were discovered. Exploration was also carried out on the Gezzi copper-gold

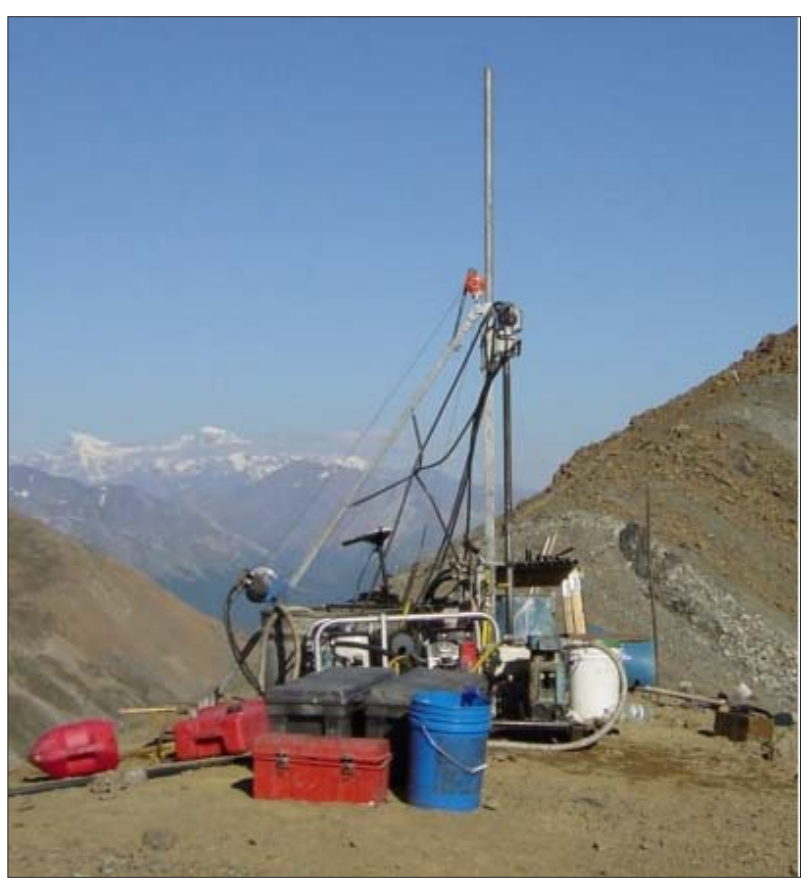

Figure 8. Core drilling by Nevada Star Resource Corp. on the Canwell nickel-copper-PGE prospect as part of the exploration program on the MAN project. Photo by Peter Bittenbender. 
prospect, an intrusion-hosted deposit with bulk tonnage potential, and the Broxson gold prospect. Sampling along six old (1970s) trenches at the Gezzi prospect show potential for porphyry style, disseminated copper-gold mineralization within a gabbro intrusion. The trenches cover an area approximately 750 feet by 450 feet. The best chip sample collected along the trenches contained 1.42 percent copper and 0.020 ounces per ton gold for 19.7 feet of trench length. Primary mineralization consists of disseminated chalcopyrite, but copper mineralization in the trenches occurs mainly as secondary minerals. Nearby occurrences of copper-gold skarn mineralization in Specimen Creek may be related to the Gezzi copper-gold zone.

Nevada Star also staked 36 new claims (720 acres) to cover a mineralized portion of the Rainy Complex. Nevada Star's claims now cover the entire Rainy mafic-ultramafic complex, one of the largest (12 miles long by up to 1 mile wide) in the MAN project area. The newly acquired claims cover a zone of disseminated to net-textured sulfide mineralization near the footwall of the Rainy Complex, traced in float along a 2,400-foot length. Two grab float samples collected during the past field season had geochemical results of up to 1.15 percent nickel, 1.27 percent copper, 0.02 ounces per ton platinum, 0.035 ounces per ton palladium, and 0.019 ounces per ton gold.

The MAN project area was also the focus of ground and airborne geophysical surveys by the USGS and BLM, as well as regional metallogenic studies by Dr. Larry Hulbert of the Geological Survey of Canada. Results of these studies, to be released in 2003, are expected to add significantly to the understanding of the nickel-PGE mineral potential of the Nikolai intrusive-extrusive complex. These studies will aid in target definition, particularly in the southern Tangle area, where the area is obscured from direct observation by a thin cover of glacial overburden.

Golconda Resources Ltd., as operator and 51 percent owner, with joint venture partners Shear Minerals Ltd. and Shulin Lake Mining Inc., announced what is thought to be the first ever lode diamond discovery in Alaska at their Shulin Lake property in southcentral Alaska near Talkeetna. In the spring of 2002, Golconda drilled 11 holes (totaling more than 4,900 feet), of which the last six holes were core holes into what is interpreted, based on petrographic work, to be a maar-like sequence of interbedded volcaniclastic and tuffaceous rocks containing olivine and pyroxene. The holes were spaced over an area of about 2,000 feet by 1,000 feet and intersected an interfingering sequence of clayaltered tuffs and reworked pyroclastics. The reworked pyroclastics contain fragments of volcanic breccias, pebbles, and mafic to ultramafic fragments, and are thought to represent the crater facies of a volcanic pipe-like structure. The material is interpreted to be locally derived, as most of the fragments are still partly coated with fine-grained tuffaceous material. Golconda interprets the geometry of this unit to show similarities to lamproitic intrusions. Golconda personnel collected a total of 18 random samples from drill holes 8 through 10 . Samples were shipped to Lakefield Research for caustic fusion and diamond recovery. A 22-pound sample contained 15 microdiamonds (defined as less than 0.02 inches in one direction with a minimum dimension of 0.004 inches in one direction) and one macrodiamond measuring 0.028 by 0.022 by 0.018 inches. Lakefield characterizes these diamonds as generally being white, transparent, mostly fragments, some with crystal faces, frosted surfaces, and graphite coatings. This sample was taken from hole 10 at a depth from 574 to 609 feet. All 18 samples yielded synthetic diamonds derived from the drilling operation including 44 synthetic diamonds from the diamondiferous sample described above.

Five additional samples from the spring drilling were sent to Lakefield Research for micro-diamond analysis. These samples were taken from drill hole 10 in order to follow up the diamond discovery. One microdiamond was recovered from a sample taken from 562 to 574 feet directly above the diamond-bearing zone. This diamond-bearing interval is described as being a graded sequence of volcaniclastic rock with a thickness of 47 feet.

The Shulin Lake joint venture later completed a second drill program that followed up the diamond-bearing zone. A total of five holes were drilled (02-11 to $02-15$ ) totaling 3,221 feet. The graded horizon similar to that from hole 10 was recognized in several of the new drill holes from which samples will be sent for microdiamond analysis and indicator mineral chemistry. No results were announced from the later drilling.

A review by Golconda of airborne geophysical data from the Shulin Lake property recognized anomalies and structural trends north of the current drilling area that are coincident with features from satellite imagery. One anomaly is a complex circular feature 1.2 miles in diameter interpreted to be a volcanic center (potential pipe) and the source of the diamondiferous volcanic system. No outcrops are present in the area, but two samples spaced about one-quarter mile apart were taken from the bottom of little rivulets. One sample contained mostly granitic components and the other contained mainly volcanic components, but both samples contained fresh single grains of chrome diopside. The joint venture staked additional claims covering 4,500 acres and now controls an area of about 18,000 acres. In February 2003, when the ground is frozen, a bulldozer will dig exploration trenches and drilling will begin shortly thereafter. The geologic context of this diamond discovery continues to be discussed within the Alaskan exploration community.

Kennecott Exploration Co. entered into an agreement with Fort Knox Gold Resources Inc. to explore the GUN state mining claims near Sheep Creek. As part of the exploration, Kennecott planned to drill up to ten core holes. No 
results were announced. Northridge Exploration continued exploration for massive-sulfide mineralization on the Forbes-Emerick property near Isabel Pass.

\section{SOUTHWESTERN REGION}

News from the Donlin Creek gold project dominated Alaska's exploration sector during 2002. Exploration expenditures on the Donlin Creek property since its discovery in 1988 are greater than $\$ 45$ million. Gold mineralization is associated with disseminated sulfides, sulfide veinlets, and quartz-carbonate-sulfide veins in sericite-altered igneous dikes and sills and host sedimentary rocks. A new resource announced in early 2002 increased measured and indicated resources to 4.4 million ounces of gold grading 0.152 ounces per ton, and inferred resources to 6.2 million ounces of gold grading 0.152 ounces per ton (table 6 ). Total resources are 22.9 million ounces of gold at an average grade of 0.09 ounces per ton, ranking Donlin Creek as the 22nd largest gold deposit ever discovered in the world. Continued aggressive exploration during 2002 added to these resources, with new discoveries at Akivik Zone, Aurora Zone, and Far East Zone. During the 2002 program, NovaGold completed 347 drill holes (195 core holes and 152 rotary holes) for a total of 167,352 feet. This includes 128,472 feet of core drilling and 38,880 feet of rotary drilling in 2002. Location of 2002 drilling at the Donlin Creek property and sites of specific mineralized areas are shown on figure 9 .

Highlights from the 2002 core drilling program at Donlin Creek are numerous. In the ACMA area, mineralized inter- cepts include hole DC02-679 with 297.3 feet grading 0.13 ounces per ton gold, drill hole DC02-870 with 183.7 feet grading 0.21 ounces per ton gold, and drill hole DC02-878 with 53.3 feet grading 0.39 ounces per ton gold. In the Akivik area, gold mineralization is largely within Kuskokwim Group sedimentary rocks and results from drilling include: Hole DC02-673 with 58 feet grading 0.26 ounces per ton gold; hole DC02-677 with 195 feet grading 0.20 ounces per ton gold and 150 feet grading 0.18 ounces per ton gold; hole DC02-688 with 59 feet grading 0.16 ounces per ton gold; hole DC02-723 with 52.5 feet grading 0.96 ounces per ton gold; hole DC02-727 with 57.4 feet grading 0.20 ounces per ton gold; hole DC02-856 with 22.6 feet grading 0.607 ounces per ton gold; hole DC02-858 with 12.8 feet grading 0.367 ounces per ton gold and another intercept of 25.25 feet of 0.114 ounces per ton gold; hole DC02-887 with 63.1 feet grading 0.26 ounces per ton gold; and hole DC02-941 with 82.0 feet grading 0.21 ounces per ton gold and another 59.9 foot interval grading 0.27 ounces per ton gold. Follow-up core holes at the new Aurora and 400 gold zones intercepted high-grade gold mineralization including: Hole DC02-730 with 20 feet grading 0.16 ounces per ton gold; hole DC02-732 with 26 feet grading 0.13 ounces per ton gold and 23 feet grading 0.11 ounces per ton gold; and hole DC02-744 containing 223 feet grading 0.10 ounces per ton gold (including 103 feet grading 0.15 ounces per ton gold); hole DC02-740 with 45.9 feet grading 0.27 ounces per ton gold; hole DC02-741 with 65.6 feet grading 0.23 ounces per ton gold; and hole DC02-855 with 62.3 feet

Table 6. 2002 Donlin Creek gold resource estimates ${ }^{a}$

\begin{tabular}{|c|c|c|c|c|c|c|c|}
\hline \multicolumn{8}{|c|}{ November 2002 updated resource estimates } \\
\hline \multicolumn{4}{|c|}{0.058 ounces per ton gold cut off grade } & \multicolumn{4}{|c|}{0.044 ounces per ton gold cut off grade } \\
\hline $\begin{array}{l}\text { Resource } \\
\text { Category }\end{array}$ & $\begin{array}{c}\text { Tons } \\
\text { (Millions) }\end{array}$ & $\begin{array}{l}\text { Gold Grade } \\
\text { Ounces/Ton }\end{array}$ & $\begin{array}{c}\text { Contained } \\
\text { Ounces }\end{array}$ & $\begin{array}{l}\text { Resource } \\
\text { Category }\end{array}$ & $\begin{array}{c}\text { Tons } \\
\text { (Millions) }\end{array}$ & $\begin{array}{l}\text { Gold Grade } \\
\text { Ounces/Ton }\end{array}$ & $\begin{array}{c}\text { Contained } \\
\text { Ounces }\end{array}$ \\
\hline Measured & 5.614 & 0.111 & 623,000 & Measured & 7.368 & 0.097 & 713,000 \\
\hline Indicated & 75.094 & 0.102 & $7,636,000$ & Indicated & 106.395 & 0.087 & $9,220,000$ \\
\hline Total M\&I: & 80.708 & 0.102 & $8,259,000$ & Total M\&I: & 113.763 & 0.087 & $9,933,000$ \\
\hline Inferred & 146.197 & 0.102 & $14,829,000$ & Inferred & 205.819 & 0.087 & $17,849,000$ \\
\hline \multicolumn{8}{|c|}{ Previous March 2002 Donlin Creek resource estimates } \\
\hline \multicolumn{4}{|c|}{0.058 ounces per ton gold cut off grade } & \multicolumn{4}{|c|}{0.044 ounces per ton gold cut off grade } \\
\hline $\begin{array}{l}\text { Resource } \\
\text { Category }\end{array}$ & $\begin{array}{c}\text { Tons } \\
\text { (Millions) }\end{array}$ & $\begin{array}{l}\text { Gold Grade } \\
\text { Ounces/Ton }\end{array}$ & $\begin{array}{l}\text { Contained } \\
\text { Ounces }\end{array}$ & $\begin{array}{l}\text { Resource } \\
\text { Category }\end{array}$ & $\begin{array}{c}\text { Tons } \\
\text { (Millions) }\end{array}$ & $\begin{array}{l}\text { Gold Grade } \\
\text { Ounces/Ton }\end{array}$ & $\begin{array}{c}\text { Contained } \\
\text { Ounces }\end{array}$ \\
\hline Measured & 5.571 & 0.112 & 623,000 & Measured & 7.268 & 0.098 & 710,000 \\
\hline Indicated & 75.968 & 0.102 & $7,732,000$ & Indicated & 107.508 & 0.087 & $9,329,000$ \\
\hline Total M\&I & 81.539 & 0.102 & $8,347,000$ & Total M\&I: & 114.776 & 0.088 & $10,040,000$ \\
\hline Inferred & 101.890 & 0.107 & $10,877,000$ & Inferred & 142.357 & 0.091 & $12,921,000$ \\
\hline
\end{tabular}

Note: Tons and Contained Ounces are rounded to the nearest 1,000. Total M\&I = Total Measured \& Indicated Resource.

${ }^{\mathrm{a} A s}$ of December 2002 from NovaGold Resources Inc. press releases. 
grading 0.19 ounces per ton gold, 42.7 feet grading 0.21 ounces per ton gold, and 107 feet grading 0.13 ounces per ton gold. At the Far East zone, reverse-circulation drilling included drill hole DR02-786, which intersected four significant intervals of mineralization, the best of which was 40 feet grading 0.23 ounces per ton gold. Other significant drill intercepts came from the Vortex zone (hole DC02-697 with 46.6 feet grading 0.152 ounces per ton gold and hole DC02-698 with 50 feet grading 0.167 ounces per ton gold) and the North Acma zone (57.4 feet grading 0.199 ounces per ton gold and hole DR02-752 with 29.9 feet grading 0.287 ounces per ton gold).

A new interim resource estimate for the Donlin Creek gold deposit announced late in 2002 indicated nearly a 40 percent increase in inferred gold resources by 4.0 million ounces at a discovery cost of less than $\$ 2$ per ounce. This estimate is based on core drill results through October 2002 primarily in the new Akivik, Aurora, and 400 target areas. These new resource areas are outside the main Acma and Lewis deposit areas. Assay results from the late-year South Acma, South Aurora/400 drilling were not available in time for inclusion in this estimation. Due to the widely spaced ( 325 feet by 325 feet) core drilling in these areas these new resources are all in the inferred category. The previous Inferred Resource as defined in the March 2002 Scoping Study using a 0.058 ounces per ton gold cut-off grade was estimated at 10.9 million ounces grading 0.107 ounces per ton gold. The new total Inferred Resource has increased to 14.8 million ounces grading 0.102 ounces per

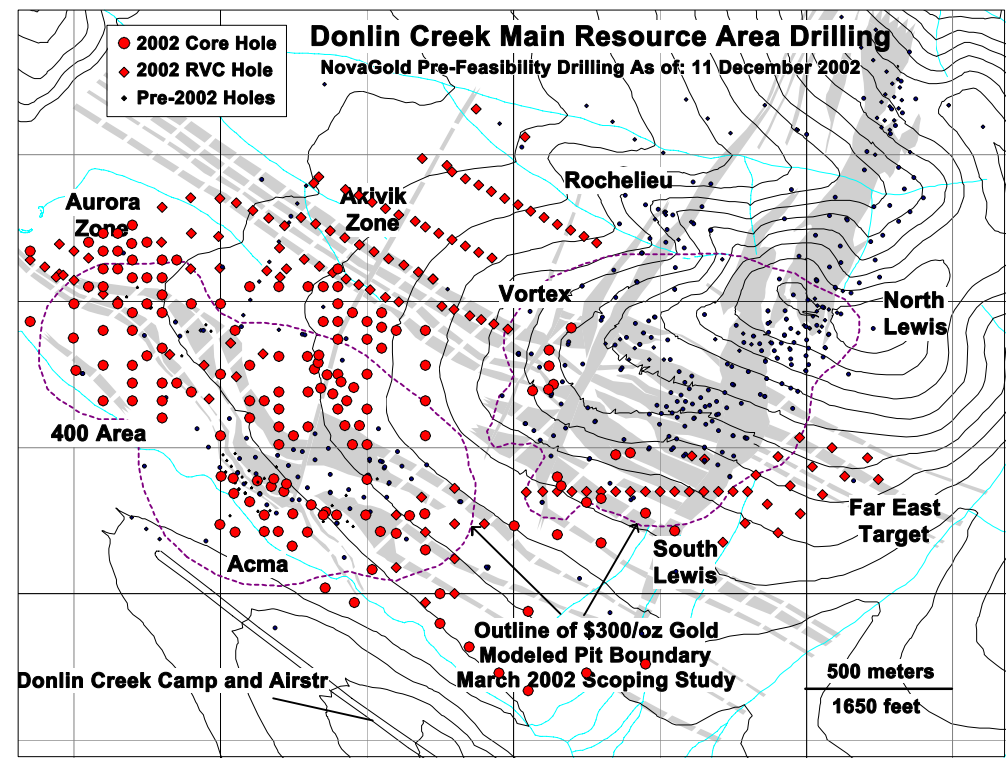

Figure 9. Map of gold resource areas, 2002 core, and 2002 reversecirculation holes at the Donlin Creek gold property. Image from NovaGold Resources Inc. Web site (http://www.novagold.net. DonlinDrillMap_11Dec02.pdf). ton gold with a total Measured and Indicated Resource of 8.3 million ounces grading 0.102 ounces per ton gold using a 0.058 ounces per ton gold cut-off grade.

NovaGold completed its required \$10 million expenditure requirement to earn a 70 percent interest in the Donlin Creek Project from Placer Dome. NovaGold's accelerated exploration program more than doubled the higher grade contained gold estimates at the Donlin Creek gold project. A preliminary independent economic assessment study completed last spring confirmed that the project may be developed into a major new gold producer that, with additional exploration and engineering work, could produce 1 million ounces of gold per year.

Placer Dome has until mid February 2003 to determine its future level of participation in the Donlin Creek Project. The company is considering whether to contribute to the development of the Donlin project at a 30 percent participating interest level with NovaGold remaining as operator at 70 percent ownership; or choose to earn an additional 40 percent interest in the project in 5 years or less by spending a minimum of $\$ 30$ million toward project development, completing a project feasibility study, and committing to build a mine that produces not less than 600,000 ounces of gold per year. Under the latter option Placer Dome would not earn any incremental additional interest in the project above their current 30 percent level until all of the above conditions are met within the maximum 5-year timeframe. NovaGold would not be required to contribute any additional funding up to $\$ 30$ million and at NovaGold's election

Placer Dome would assist with financing for any development costs exceeding \$30 million, with NovaGold's share of the development costs to be repaid out of a portion of its future mine cash flow.

Northern Dynasty Minerals Ltd. made three important new discoveries during an exploration drilling program at the Pebble project located near Lake Iliamna. The program consisted of 68 widely spaced core holes $(37,000$ feet total) within the 34.3square-mile copper-gold-molybdenum mineralized system that extends 13 miles southwest of the known 1-billion-ton Pebble deposit that contains 6.6 billion pounds of copper and 10.9 million ounces of gold. A detailed review and analysis of core from the Pebble deposit was also undertaken and led to a reinterpretation of the deposit's geology. A second granodiorite stock is recognized in the poorly explored northeast portion of the deposit. Several structural features that appear to control higher grade mineralization have also been recognized. 
A new copper-gold-molybdenum porphyry deposit was discovered by drill holes 34 and 38, spaced 1,475 feet apart and located 7.5 miles southwest of the Pebble deposit. Both holes encountered wide intervals of gold-copper-molybdenum porphyry-style mineralization. Hole 34 intersected 210 feet of mineralization, starting at 70 -foot depth, grading 0.30 percent copper and 0.006 ounces per ton gold. Hole 38 intersected 525 feet of mineralization starting at 116 -foot depth grading 0.32 percent copper, 0.02 percent molybdenum, and 0.010 ounces per ton gold. Assay results show excellent continuity of mineralization and correlation between gold and copper values. The new porphyry copper-gold-molybdenum discovery is wide open in all directions and occurs in a 3.9-square-mile covered area associated with a very extensive induced polarization (IP) chargeability anomaly. The closest drill hole to the discovery is 1.2 miles to the east. A phase two program of 16 holes outlined mineralization for more than 3,300 feet along strike and up to 2,000 feet in width. Drill highlights include hole 49, which intersected 489 feet of mineralization grading 0.42 percent copper and 0.012 ounces of gold per ton; hole 50 with 0.30 percent copper and 0.033 ounces of gold per ton over 98 feet; hole 45, which intersected 0.41 percent copper and 0.009 ounces of gold per ton over 102 feet; and hole 44 with 0.40 percent copper and 0.011 ounces of gold per ton over 112 feet.

Substantial copper-gold values in chalcopyrite-pyrrhotite skarn-style mineralization were encountered in drill hole 37, located 10 miles to the southwest of the Pebble deposit and 3.1 miles west of hole 38 . Drill hole 37 intersected 259 feet grading 0.4 percent copper and 0.029 ounces per ton gold, which included 21.3 feet grading 0.106 ounces per ton gold and 1.72 percent copper starting at 155.5 -foot depth. This newly discovered copper-gold body is associated with a very strong, 0.6-mile-long, east-west-trending gold-copper soil geochemical anomaly that is open-ended in both directions.

High-grade gold was encountered 3.1 miles south of the Pebble deposit. Drill hole 25 intersected 0.84 ounces per ton gold over 20 feet starting at a 230 -foot depth. This hole is situated within an intense gold-in-soil geochemical anomaly, measuring 0.5 mile by 0.5 mile, and is 1,150 feet southwest of historic Teck Cominco drill hole 9, which intersected an interval grading 0.99 ounces per ton gold over 5 feet. The discovery is open in all directions. Additional drilling in a phase two program encountered significant structurally-controlled gold mineralization. Drill hole 62 intersected strong silicification and multiple stages of brecciation in three intervals totaling 10 feet with an average grade of 0.446 ounces of gold per ton.

Ventures Resource Corp. announced results from a 2002 field program at its Donlin Creek North claim blocks, and at Golden Apex in the 85,000-acre Flat (Iditarod mining district) property. The $\$ 480,000$ program was managed by
WGM Inc. Ventures expanded its 17,000-acre Donlin Creek North project Timb claim block by staking an additional 4,800 acres ( 7.5 square miles). The Donlin Creek North group includes the Timb, Widg, Mose, and Eldo claim blocks that are strategically located between two gold districts. On the south, the Timb claims abut NovaGold's Donlin Creek deposit. On the north, Donlin Creek North claims cross the southeast part of the 85,000 -acre Flat Property in the Iditarod mining district. About 1,800 stream sediment samples were taken in an 800-square-mile area encompassing 15 Donlin Creek North claim blocks. Samples of quartz-stockwork-veined rhyolite and associated hornfels, collected during 2002 in the Timb extension area, contain up to 0.0016 ounces per ton gold and anomalous gold pathfinder elements, including silver (up to 1.3 ounces per ton), arsenic (up to greater than 1 percent), mercury (up to 0.003 percent) and antimony (up to 0.1 percent), and up to 4.9 percent copper and 12.6 percent lead. Quartz-veined rhyolite on the SD property contained up to 0.01 ounces per ton gold and 0.12 percent arsenic.

At the Ada claims, 20 miles east of Flat, Ventures Resource Corp. discovered an epithermal gold occurrence. Rocks are cut by faults associated with breccia that contains silicified igneous and wallrock fragments, with sulfides in chalcedonic silica flooding. Twenty-six rock samples contain up to 0.037 percent mercury, up to 0.385 percent antimony; and five samples contain detectable gold values ranging from 0.0013 to 0.022 ounces per ton gold. Soil sampling outlines an 800 - by 1,800 -foot area with more than 0.0006 ounces per ton gold, open in all directions. Very high mercury and antimony values, anomalous gold, and the alteration, brecciation, and chalcedonic silicification indicate possible epithermal gold systems.

In 2003, Ventures anticipates startup of drilling at the Golden Apex and Divide properties, detailed examination of the Ada claims, upgrading of other Flat prospects to the drilling phase, and follow-up of additional Donlin Creek North prospects. In an effort to accelerate its various mineral programs, Ventures is exploring joint venture and other financing options.

TNR Resources Ltd. signed a joint-venture agreement with NovaGold Resources Inc. on NovaGold's 100-percentowned Shotgun gold deposit. Under the terms of the agreement, TNR Resources can earn up to a 50 percent interest in the million-ounce gold deposit by spending $\$ 3$ million on exploration over the next 4 years to advance the project towards a production decision. TNR Resources has a further option to earn an additional 20 percent interest in the Shotgun project subject to a back-in option for NovaGold. A $\$ 500,000$ exploration program was planned for 2003

TNR Resources Ltd. also acquired the right from BHP Minerals International Exploration Inc. (BHP) to earn a 70 percent interest in three claim blocks held by BHP and 
located in the Lake Iliamna-Bristol Bay area of southwestern Alaska. Exploration on the Iliamna-Bristol claims was originally conducted in 2000 by Rio Algom Exploration Inc. and consisted of a regional airborne magnetic survey followed by reconnaissance geology and wide spaced induced polarization/resistivity geophysical surveys in selected areas. BHP's results suggested that these claims had potential to host porphyry copper-gold-molybdenum systems comparable to the Pebble deposit, located 60 miles to the northeast. TNR granted BHP 1,000,000 share purchase warrants, agreed to incur $\$ 800,000$ in expenditures on the property, including at least 5,700 feet of diamond drilling within 2 years, and BHP has the right to back in to 70 percent ownership of the property by taking the project to feasibility. TNR plans detailed ground geophysics to define drill targets and possible drilling in 2003.

\section{SOUTHEASTERN REGION}

Quaterra Resources Inc. announced that a helicopterborne geophysical survey on its 100-percent-owned Duke Island copper-nickel-PGE prospect identified an extensive zone of potential sulfide mineralization in an unmapped and unsampled area of the 10- by 12-mile island. The Aeroquest Ltd. helicopter-borne IMPULSE ${ }^{\circledR}$ multifrequency electromagnetic and magnetometer survey used an electromagnetic system with a 6-channel frequency domain towed bird system. The survey was completed at a 656-foot line spacing (448 line miles) with105 line miles of fill-in lines at 328-foot spacing in selected areas. The nominal EM bird terrain clearance was 100 feet. Results from the 554-line-mile survey are that areas of known mineralization generally fall within broad zones of anomalous conductivity that extend well beyond the limits of outcropping sulfides. Aeroquest identified a total of 459 high-priority anomalies, including 311 Type 1 anomalies with positive inphase response and a sharp, probable hardrock source and 148 Type 2 anomalies with a negative inphase and positive quadrature response (conductive magnetic anomalies). The largest zone of conductive anomalies occurs on the north side of the Discovery Zone and extends for 1.5 miles in an east-west direction. This zone is well north of the area drilled by Quaterra last year.

Quaterra also reported that a detailed review of the airborne geophysical survey has confirmed a number of high-priority targets. The review, by consulting geophysicist Joseph R. Inman, covered a 2.5 -mile by 2.5 -mile area and identified nine discrete, multi-anomaly zones with strike lengths ranging from 1,300 to 4,900 feet that may be indicative of massive-sulfide mineralization. Quaterra said its 2002 program at Duke Island focused on prioritizing targets for the next drilling campaign, now projected for spring 2003. Quaterra has been following up on surface sampling that returned values ranging from anomalous up to 2.8 percent copper, 0.25 percent nickel and 0.0292 ounces per ton combined platinum and palladium, and on four late 2001 drill holes from two drill pads approximately 750 feet apart. All holes intercepted disseminated, semi-massive and massive sulfides over extensive lengths.

Quaterra contracted for a preliminary Landsat Thematic Mapping (TM) analysis of the Duke Island project. The Marquis zone was used as a "type" locality and the TM imagery analysis identified two other target zones to the southwest and the southeast of the Marquis zone. Forty three samples were collected from the southwestern TM anomaly, known as the Monte zone. Of the samples collected, 21 had copper analysis results greater than 0.1 percent copper. Values for platinum, palladium, nickel, and cobalt were generally lower than seen in the Marquis zone, with maximum values of 0.009 ounces per ton, 0.014 ounces per ton, 0.08 percent, and 0.02 percent, respectively. Quaterra interprets the Monte zone to be on the distal edge of the Marquis zone mineralized system.

Quaterra also reported that the joint venture to explore the Union Bay PGE prospect north of Ketchikan has been terminated to permit Quaterra to focus its resources on its 100 -percent-owned projects. After that option was terminated, Freegold Ventures Ltd. (Freegold) and Pacific North West Capital Corp. (PFN) entered into an option/joint-venture agreement on the Union Bay Platinum Project. PFN may earn a 50 percent interest in the project by expending $\$ 1$ million on exploration, participating in the current Freegold financing for $\$ 165,000$, making cash payments totaling $\$ 100,000$ over 4 years, and issuing 60,000 PFN shares. PFN may earn a 60 percent interest by completing a feasibility study, and a 70 percent interest by arranging all financing through commercial production. The Union Bay property is centered on a 7.5-mile by 4.3-mile zoned UralAlaska complex consisting of a dunite core grading outward through olivine pyroxenite and pyroxenite to hornblendite and gabbro. Freegold originally acquired the property in 2000 after a regional review of PGE potential in the Alexander Platinum Belt of southeastern Alaska. Initial efforts were concentrated on the northeastern part of the Union Bay complex where government surveys indicated values up to 0.55 ounces per ton platinum in pan concentrates.

Results from unpublished graduate thesis work conducted at the University of Alaska Fairbanks on PGE mineralization at the Union Bay prospect have major implications for exploration. Most significant are results from multidisciplinary studies that indicate that PGE mineralization results from hydrothermal fluids and not a primary magmatic genesis. Pyroxene veins crosscut all other rock units and PGE-bearing magnetite is associated with the pyroxene. Magnetite veins clearly cut magmatic layering.

Kennecott Minerals Co. continued exploration to expand ore zones at the Greens Creek Mine. Exploration remained focused on the silver-rich 200 South orebody, where new resources were successfully identified in 2001 
and 2002. Surface exploration targeted mine type structures in the immediate mine area and adjoining claims.

Olympic Resources Group LLC discovered new volcanogenic massive-sulfide (VMS) mineralization with a hydrothermal precious-metal overprint on the southern part of Woewodski Island. Mineralization is hosted in highly quartz-sericite-altered mafic volcanic tuff and tuff breccia of the late Triassic Hyd Group. Mineralization can be traced laterally for 6,000 feet and consists of massive to semimassive pyrite, sphalerite, and galena and unidentified silver- and gold-bearing minerals. A small quartz monzodiorite intrusion, coincident with a strong magnetic low in the BLM's Wrangell/Stikine airborne geophysical survey, occurs in the prospect area center and induced an apparent hydrothermal overprint and introduced a secondary gold mineralizing event. Olympic Resources completed a five hole ( 1,100 feet $)$ diamond drilling program in the Brushy Creek area. Holes 4 and 5 contained massive to semimassive mineralization, with the best intercept from hole 4 from 115 to 196 feet containing 1.65 percent zinc, 0.35 percent lead, 0.97 ounces per ton silver, and 0.007 ounces per ton gold, including 7 feet (from 175 to 182 feet) of 4.66 percent zinc, 0.82 percent lead, 1.88 ounces per ton silver, and 0.017 ounces per ton gold. A total of 160 drill samples were collected for geochemical analysis. Some platinum-palladium mineralization was discovered associated with a medium-grained gabbro on the north side of lower Brushy Creek. Olympic Resources believes that the massive-sulfide mineralization and host rocks are equivalent to rocks hosting the Greens Creek deposit on Admiralty Island.

\section{DEVELOPMENT}

Development expenditures in 2002 were $\$ 34.1$ million, down 58 percent from the $\$ 81.16$ million invested in 2001 .

Development in 2002 was reported at Fort Knox, True North, Usibelli, Kensington, and Greens Creek mines and the Pogo project. There was also a minor amount of development reported at many of the small rock quarries, gravel pits, and placer gold mines. For the first time in many years, there was no development at the Red Dog Mine.

Table 7 shows the regional employment and development investment, and table 8 compares the 2002 investment with that of the previous 20 years. Figure 10 shows the locations of selected development projects.

\section{NORTHERN REGION}

Silverado Gold Mines Ltd. began tunneling into the deep channel on claims 1 and 2 below Discovery between Faye and Archibald creeks at the Nolan placer gold mine near Wiseman in northern Alaska. Minor development projects were reported at several small placer gold mines in the northern region.

\section{WESTERN REGION}

Several of the small placer gold mines on the Seward Peninsula reported minor development such as stripping frozen overburden and road or pond construction.

\section{EASTERN INTERIOR REGION}

At Fort Knox Mine, development consisted of in-pit drilling, engineering, design, and construction of a tailings thickening system, and raising of the level of the tailings dam. At True North Mine, Fairbanks Gold Mining Inc. purchased a new fleet of haul trucks, and began expansion of the mine area after receiving final permit approval in June, and overcoming objections in August.

At Usibelli Coal Mine near Healy, construction of a 7mile road and stripping of the Two Bull Ridge pit prepared for the move of the walking dragline from the operating Poker Flats pit.

At the Pogo gold project east of Fairbanks, Teck-Pogo Inc. and partner Sumitomo Metal Mining America Inc. conducted a core-drilling program of infill drilling of the L2 vein to update the indicated/inferred resource calculations and to assist in geotechnical modeling. The field activity was concurrent with preparation of a Draft Environmental Impact Statement and engineering studies.

Many of the placer gold mines in the region reported minor development projects.

\section{SOUTHCENTRAL REGION}

Some of the placer gold mines in the region reported development, mainly in road construction and ground preparation.

\section{SOUTHWESTERN REGION}

The only development reported in 2002 was for sources of industrial materials, and two small placer gold mines.

\section{ALASKA PENINSULA REGION}

No mineral development activity was reported in this region in 2002.

\section{SOUTHEASTERN REGION}

In southeastern Alaska, Coeur Alaska continued its efforts to permit the Kensington/Jualin Mine complex north of Juneau. Optimization studies of new mining methods 
Table 7. Reported mineral development expenditures and employment in Alaska by commodity and region, 2002

\begin{tabular}{|c|c|c|c|c|c|c|c|}
\hline & Northern & Western & $\begin{array}{l}\text { Eastern } \\
\text { interior }\end{array}$ & $\begin{array}{l}\text { South- } \\
\text { central }\end{array}$ & $\begin{array}{l}\text { South- } \\
\text { western }\end{array}$ & $\begin{array}{l}\text { South- } \\
\text { eastern }\end{array}$ & Total \\
\hline \multicolumn{8}{|c|}{ Development expenditures } \\
\hline Base metals & - & - & - & - & - & $\$ \quad--$ & \$ $\quad--$ \\
\hline Polymetallic & - & - & - & - & - & $5,700,000$ & $5,700,000$ \\
\hline \multicolumn{8}{|l|}{ Precious metals } \\
\hline Placer & $2,050,000$ & 100,000 & 60,000 & - & 45,000 & - & $2,255,000$ \\
\hline Lode & - & 100,000 & $22,200,000$ & - & - - & $2,100,000$ & $24,400,000$ \\
\hline Coal and peat & - & -- & $1,450,000$ & - - & - - & - & $1,450,000$ \\
\hline Industrial minerals & - & 50,000 & 40,000 & 85,000 & 20,000 & 55,000 & 250,000 \\
\hline TOTAL & $\$ 2,050,000$ & $\$ 250,000$ & $\$ 23,750,000$ & $\$ 85,000$ & $\$ 65,000$ & $\$ 7,855,000$ & $\$ 34,055,000$ \\
\hline \multicolumn{8}{|c|}{ Development employment } \\
\hline \multicolumn{8}{|l|}{ Employment } \\
\hline Workdays & 4,500 & 1,650 & 21,750 & 354 & 450 & 6,170 & $\mathbf{3 4 , 8 7 4}$ \\
\hline Workyears $^{\mathrm{a}}$ & 17 & 6 & 84 & 2 & 2 & 24 & 135 \\
\hline \multicolumn{8}{|c|}{ Number of companies } \\
\hline reporting ${ }^{b}$ & 3 & 3 & 7 & 3 & 3 & 4 & 23 \\
\hline
\end{tabular}

${ }^{\mathrm{a}}$ Based on 260-day workyear.

${ }^{\mathrm{b}}$ Some companies active in more than one area.

No development expenditures or employment reported for Alaska Peninsula region in 2002.

- - No expenditures reported.

Table 8. Reported mineral development expenditures in Alaska by commodity, 1982-2002

\begin{tabular}{|c|c|c|c|c|c|c|}
\hline & Base metals & Polymetallics & Precious metals & Industrial minerals & Coal and peat & Total \\
\hline 1982 & $\$ 10,270,000$ & N/A & $\$ 19,320,000$ & $\$ 4,251,000$ & $\$ 7,750,000$ & $41,591,000$ \\
\hline 1983 & $19,500,000$ & N/A & $7,112,500$ & $1,000,000$ & 250,000 & $27,862,500$ \\
\hline 1984 & $10,710,500$ & N/A & $15,058,555$ & 579,000 & $27,000,000$ & $53,348,055$ \\
\hline 1985 & $13,000,000$ & $\mathrm{~N} / \mathrm{A}$ & $16,890,755$ & $1,830,000$ & $2,400,000$ & $34,120,755$ \\
\hline 1986 & $3,260,800$ & $8,000,000$ & $12,417,172$ & 124,000 & 530,000 & $24,331,972$ \\
\hline 1987 & $38,080,000$ & $48,000,000$ & $13,640,848$ & 188,000 & 342,000 & $100,250,848$ \\
\hline 1988 & $165,500,000$ & $69,000,000$ & $40,445,400$ & - & - & $274,945,400$ \\
\hline 1989 & $118,200,000$ & 411,000 & $6,465,350$ & $7,000,000$ & $2,196,000$ & $134,272,350$ \\
\hline 1990 & - & $4,101,000$ & $7,136,500$ & 30,000 & $3,079,000$ & $14,346,500$ \\
\hline 1991 & - - & $8,000,000$ & $14,994,350$ & 262,000 & $2,318,000$ & $25,574,350$ \\
\hline 1992 & 80,000 & $4,300,000$ & $23,151,300$ & 404,000 & $1,655,000$ & $29,590,300$ \\
\hline 1993 & - - & $10,731,136$ & $15,103,000$ & 433,500 & $1,400,000$ & $27,667,636$ \\
\hline 1994 & $10,000,000$ & $5,000,000$ & $27,392,850$ & 5,000 & $2,545,000$ & $44,942,850$ \\
\hline 1995 & $11,200,000$ & $9,590,000$ & $127,165,750$ & 426,000 & 200,000 & $148,581,750$ \\
\hline 1996 & $60,000,000$ & $60,100,000$ & $273,042,000$ & 495,000 & 400,000 & $394,037,000$ \\
\hline 1997 & $133,880,000$ & $7,300,000$ & $26,299,000$ & 500,000 & 410,000 & $168,389,000$ \\
\hline 1998 & $28,000,000$ & $5,600,000$ & $15,602,000$ & $5,355,000$ & 850,000 & $55,407,000$ \\
\hline 1999 & $12,500,000$ & $2,500,000$ & $15,864,000$ & 400,000 & $2,575,000$ & $33,839,000$ \\
\hline 2000 & $100,000,000$ & $16,400,000$ & $24,699,000$ & 611,000 & - - & $141,710,000$ \\
\hline 2001 & $43,800,000$ & $3,300,000$ & $32,719,000$ & 300,000 & $1,040,000$ & $81,159,000$ \\
\hline 2002 & - - & $5,700,000$ & $26,655,000$ & 250,000 & $1,450,000$ & $34,055,000$ \\
\hline TOTAL & $\$ 777,981,300$ & $\$ 268,033,136$ & $\$ 761,174,330$ & $\$ 24,443,500$ & $\$ 58,390,000$ & $\$ 1,890,022,266$ \\
\hline
\end{tabular}

$\mathrm{N} / \mathrm{A}=$ Figures not available prior to 1986 .

- - Not reported. 


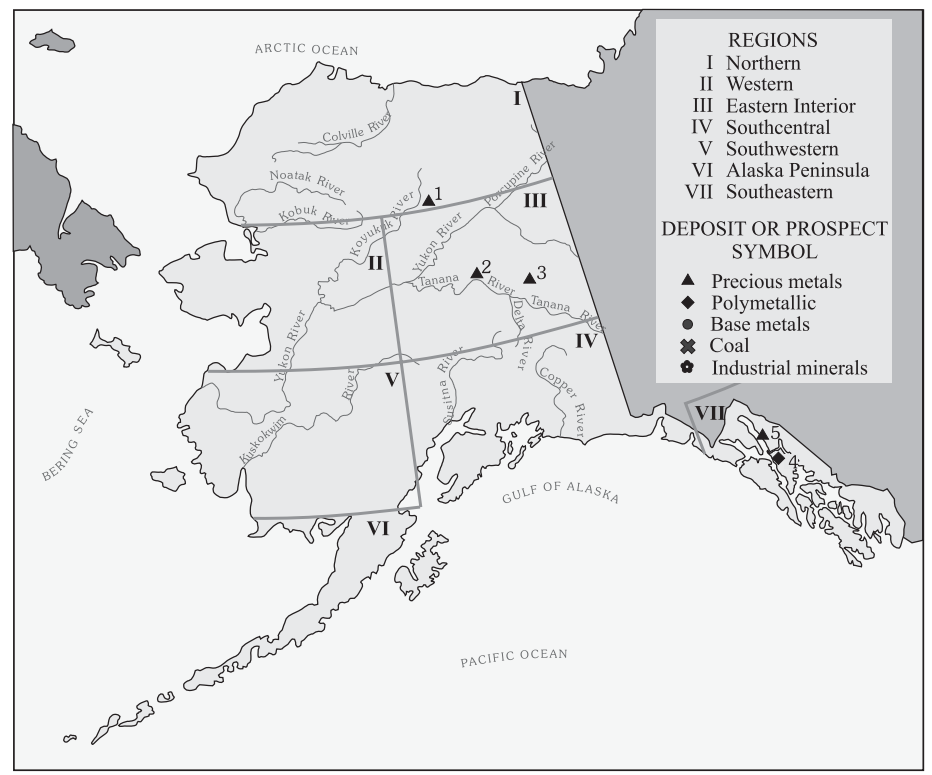

Figure 10. Selected mineral development projects in Alaska, 2002.

\section{Northern Region}

1. Nolan Placer Mine (Silverado Gold Mines Inc.) - underground placer gold mine

\section{Western Region}

\section{Eastern Interior Region}

2. Fairbanks area

a. Fort Knox Mine-Kinross Gold Corp. (drilling)

b. Several open-pit and underground placer mines

c. True North Mine, Kinross Gold Corp. (road and mine construction)

3. Pogo Project-Teck Corp./Sumitomo Metals Mining America Inc. (permitting)

\section{Southcentral Region}

V Southwestern Region

VI Alaska Peninsula Region

VII Southeastern Region

4. Greens Creek Mine-Kennecott Mineral Co./ Hecla Mining Co. (access drifting, underground drilling)

5. Kensington Mine-Coeur Alaska (optimization studies) reduced the cost of building the mine by more than $\$ 56$ million, and the mine redesign lowered operating costs from $\$ 282$ per ounce to $\$ 226$ per ounce.

At Greens Creek Mine, Kennecott Minerals/Hecla completed construction of their paste backfill plant, enabling the mill throughput to be increased to a record level, and continued drifting to access the orebody. Surface work included completion of the Environmental Impact Statement and design for an expanded tailings facility.

\section{PRODUCTION}

The total value of production from Alaska's mines and quarries in 2002 was $\$ 1,013$ million, up 9 percent from the $\$ 917.34$ million reported in 2001 .

Gold production was reported from the Fort Knox, Greens Creek, and Illinois Creek hard rock mines, and at least 50 placer mines. Silver was produced at Red Dog and Greens Creek mines, which were also the primary producers of zinc and lead concentrates.

The decline in the price of zinc from $\$ 0.40$ per pound in 2001 to $\$ 0.35$ in 2002 had a strongly negative influence on the profitability of Red Dog and Greens Creek mines. Conversely, Fort Knox gold mine benefited from the rise in the gold price from an average of \$271.04 per ounce in 2001 to $\$ 310.06$ in 2002 .

Table 9 shows the quantity and value of metal and material production from 2000 to 2002 . Table 10 list the miners and mines that had an Alaska Annual Placer Mining Application (APMA) for 2002, and which were reported by the U.S. Bureau of Land Management (BLM) or the State of Alaska Division of Mining, Land, \& Water (DMLW) to have had at least some production during the year. Figures 11,12 , and 13 show the historic production of sand and gravel, rock, and coal. Selected production sites are shown in figure 14.

Metals, with a value of $\$ 823$ million, accounted for 81 percent of total production; and zinc $(718,106$ dry short tons with a value of $\$ 502.7$ million) continued to be the most valuable metal in terms of the total revenue it generated. Zinc was followed by gold (562,094 ounces valued at $\$ 174.3$ million), silver (17.8 million ounces valued at $\$ 82.3$ million), and lead (146,462 tons with a value of $\$ 61.5$ million). Zinc was 61 percent of total metal value, gold was 21 percent, silver 10 percent, and lead 7.5 percent.

Table 11 shows the average metal values used in this report over the last 10 years. The 31 percent drop in the price of zinc between 2000 and 2002 is the most dramatic decrease, but gold rose 14 percent and silver rose 5.5 percent between 2001 and 2002 .

The production estimates included in this report are from 138 questionnaires returned by miners, Native corporations, agencies, and municipalities, supplemented by more than 100 phone surveys. Additional information was derived from State of Alaska Annual Placer Mining Applications (APMAs) submitted to the DMLW, but due 
Table 9. Estimated mineral production in Alaska, 2000-2002a

\begin{tabular}{|c|c|c|c|c|c|c|}
\hline \multirow[b]{2}{*}{ Metals } & \multicolumn{3}{|c|}{ Quantity } & \multicolumn{3}{|c|}{ Estimated values $^{b}$} \\
\hline & 2000 & 2001 & 2002 & 2000 & 2001 & 2002 \\
\hline Gold (ounces) & 551,982 & 550,644 & $562,094^{\mathrm{c}}$ & $\$ 154,058,000$ & $\$ 149,246,000$ & $\$ 174,283,000$ \\
\hline Silver (ounces) & $18,226,615$ & $16,798,000$ & $17,858,183$ & $90,404,000$ & $73,408,000$ & $82,326,000$ \\
\hline Copper (tons) & 1,400 & 1,400 & 1,600 & $2,296,000$ & $1,988,000$ & $2,272,000$ \\
\hline Lead (tons) & 123,224 & 127,385 & 146,462 & $51,754,000$ & $56,049,000$ & $61,514,000$ \\
\hline Zinc (tons) & 669,112 & 634,883 & 718,106 & $682,494,000$ & $507,907,000$ & $502,674,000$ \\
\hline Subtotal & & & & $\$ 981,006,000$ & $\$ 788,598,000$ & $\$ 823,069,000$ \\
\hline \multicolumn{7}{|l|}{ Industrial minerals } \\
\hline Jade and soapstone (tons) & 2.0 & 2.0 & 2.0 & $\$ \quad 25,000$ & $\$ \quad 25,000$ & $\$ \quad 25,000$ \\
\hline Sand and gravel (million tons) & 10.6 & 10.4 & 22.4 & $49,855,000$ & $55,221,000$ & $120,698,000$ \\
\hline Rock (million tons) & 5.2 & 3.1 & 3.2 & $36,588,000$ & $27,176,000$ & $31,442,000$ \\
\hline Subtotal & & & & $\$ 86,468,000$ & $\$ 82,422,000$ & $\$ 152,165,000$ \\
\hline \multicolumn{7}{|l|}{ Energy minerals } \\
\hline Coal (tons) & $1,473,000$ & $1,537,000$ & $1,158,000$ & $\$ 38,768,000$ & $\$ 48,108,000$ & $\$ 37,400,000$ \\
\hline Peat (cubic yards) & 35,600 & 36,000 & 35,000 & 178,000 & 180,000 & 175,000 \\
\hline Subtotal & & & & $\$ 38,946,000$ & $\$ 48,288,000$ & $\$ 37,575,000$ \\
\hline TOTAL & & & & $\$ 1,106,420,000$ & $\$ 919,308,000$ & $\$ 1,012,809,000$ \\
\hline
\end{tabular}

aProduction data from DGGS questionnaires, phone interviews with mine and quarry operators, Alaska Department of Transportation and Public Facilities, and federal land management agencies.

${ }^{b}$ Values for selected metal production based on average prices for each year; for 2002 — gold (\$310.06/ounce unless other value provided by operator); silver $(\$ 4.61 /$ ounce); copper $(\$ 0.71 / 1 \mathrm{~b})$; zinc $(\$ 0.35 / \mathrm{lb})$; lead $(\$ 0.21 / \mathrm{lb})$. All other values provided by mine operators. Values rounded to nearest $\$ 1,000$.

${ }^{c}$ Hardrock gold 539,713 ounces, placer gold 22,381 ounces.

Table 10. Companies and individuals reported to be producing metal in Alaska, 2002

\begin{tabular}{llll} 
Operator & \multicolumn{1}{c}{ Creek } & District & Type $^{\mathbf{a}^{2}}$ \\
& & & \\
& & NoRTHERN REGION & \\
DCE Inc. & Lake & Koyukuk & O/lacer \\
Brandon, Katherine & Myrtle & Koyukuk & Olacer \\
Frantz, Peter & Linda & Koyukuk & O/P Placer \\
Green, Steve & Davis & Koyukuk & U/G Placer \\
Hall, John & Linda & Koyukuk & O/P Placer \\
Hamm, Ralph & Hammond/Lotty/Buckeye & Koyukuk & O/P Placer \\
Jiles, O. J. & Gold Bottom & Koyukuk & O/P Placer \\
Lounsbury, Jim & Union Gulch & Koyukuk & U/G \& S/D Placer \\
Nordeen, William & Emma & Koyukuk & O/P Placer \\
Olmstead, Jim & Gold & Koyukuk & O/P Placer \\
Paradise Mining & Birch & Koyukuk & O/P Placer \\
Swenson, Lloyd & Slate & Koyukuk & O/P Placer \\
Tainter, Gary & Prospect & Koyukuk & O/P and U/G Placer \\
Tri-Con Mining & Nolan & Koyukuk & O/P Placer \\
Weisz, Larry & Hammond & Koyukuk & O/P Placer \\
Wicken, Jim & Gold & Koyukuk & HR O/P (zinc-lead-silver) \\
Teck Cominco Alaska Inc. & Red Dog Mine & Noatak &
\end{tabular}




\begin{tabular}{|c|c|c|c|}
\hline Operator & Creek & District & Type $^{\mathbf{a}}$ \\
\hline \multicolumn{4}{|c|}{ Western Region } \\
\hline Loyer, Victor & Candle & Fairhaven & O/P Placer \\
\hline Rosander, Ron & Colorado & Innoko & $\mathrm{O} / \mathrm{P}$ Placer \\
\hline American Reclamation Group, LLC. & Illinois Creek Mine & Kaiyuh & HR O/P (gold-silver) \\
\hline Benesch, George & Coffee & Kougarok & $\mathrm{O} / \mathrm{P}$ Placer \\
\hline Gumaer, Mark & Dick & Kougarok & $\mathrm{O} / \mathrm{P}$ Placer \\
\hline Lohman Mining & Coffee & Kougarok & O/P Placer \\
\hline Pushcar, Jerry & Iron & Kougarok & $\mathrm{O} / \mathrm{P}$ Placer \\
\hline Tweet, Bruce \& Doug & Kougarok & Kougarok & O/P Placer \\
\hline Magnuson, Manzie & Candle & McGrath & O/P Placer \\
\hline Gibson, Wayne & Golden & Melotzitna & O/P Placer \\
\hline Anderson, Ralph & Dry & Nome & O/P Placer \\
\hline Blake, Thomas & Iron & Nome & $\mathrm{O} / \mathrm{P}$ Placer \\
\hline Coggins, Graig & Norton Sound & Nome & S/D Placer \\
\hline Groethe, Lenhart & Tripple & Nome & O/P Placer \\
\hline Gustafson, Aaron & Norton Sound & Nome & S/D Placer \\
\hline High Bench & Anvil & Nome & O/P Placer \\
\hline Johnson, Al & Norton Sound & Nome & S/D Placer \\
\hline K \& S Leasing & Norton Sound & Nome & S/D Placer \\
\hline Krutzsch, Betty & Specimen Gulch & Nome & O/P Placer \\
\hline Lee, Robert & Norton Sound & Nome & S/D Placer \\
\hline Massie, Perry & Cripple & Nome & $\mathrm{O} / \mathrm{P}$ Placer \\
\hline McCauley, Edward & Norton Sound & Nome & S/D Placer \\
\hline McFarland, Frank & Norton Sound & Nome & S/D Placer \\
\hline Mendenhall, Perry & Darling & Nome & S/D Placer \\
\hline Olsen, Dave & Canyon & Nome & O/P Placer \\
\hline Pettigrew, Bert & Anvil & Nome & O/P Placer \\
\hline Pomrenke, Steve & Tripple & Nome & $\mathrm{O} / \mathrm{P}$ Placer \\
\hline Stamps, Thomas & Norton Sound & Nome & S/D Placer \\
\hline Sykes, Frank & Norton Sound & Nome & S/D Placer \\
\hline Turner, Martin & Norton Sound & Nome & S/D Placer \\
\hline Wade, Mike & Norton Sound & Nome & S/D Placer \\
\hline Walsh, Daniel & Gold Run & Nome & O/P Placer \\
\hline Kralik, Janos & Gold Run & Port Clarence & O/P Placer \\
\hline Stultz, Thomas & Gold Run & Port Clarence & $\mathrm{O} / \mathrm{P}$ Placer \\
\hline Tweet, Bruce \& Doug & Windy & Port Clarence & $\mathrm{O} / \mathrm{P}$ Placer \\
\hline Clay, Barry & Swift & Ruby & O/P Placer \\
\hline Tryck, Keith & Ophir & Ruby & $\mathrm{O} / \mathrm{P}$ Placer \\
\hline Sweetsir, Michael & Glen Gulch & Ruby & O/P Placer \\
\hline \multicolumn{4}{|c|}{ EASTERN INTERIOR REGION } \\
\hline Decker, James & Sheep & Bonnifield & $\mathrm{O} / \mathrm{P}$ Placer \\
\hline Jacobs, David & Eva & Bonnifield & $\mathrm{O} / \mathrm{P}$ Placer \\
\hline Kiehl, Don & Gold King & Bonnifield & $\mathrm{O} / \mathrm{P}$ Placer \\
\hline Mitchell, Rod & Roosevelte & Bonnifield & $\mathrm{O} / \mathrm{P}$ Placer \\
\hline Oudekerke, James & Moose & Bonnifield & $\mathrm{O} / \mathrm{P}$ Placer \\
\hline Totat Mining & Totatlanika & Bonnifield & $\mathrm{O} / \mathrm{P}$ Placer \\
\hline Traxler, Gene & Totatlanika & Bonnifield & $\mathrm{O} / \mathrm{P}$ Placer \\
\hline Alaska Rose Garnet & Faith & Circle & $\mathrm{O} / \mathrm{P}$ Placer \\
\hline Manuel, Paul & Crooked & Circle & $\mathrm{O} / \mathrm{P}$ Placer \\
\hline Fulton, Gordon & Switch & Circle & $\mathrm{O} / \mathrm{P}$ Placer \\
\hline Glassburn, Don & Gold Dust & Circle & $\mathrm{O} / \mathrm{P}$ Placer \\
\hline Koppenberg, Sam & Faith & Circle & O/P Placer \\
\hline Lapp, Ed \& Sons & Ketchum & Circle & $\mathrm{O} / \mathrm{P}$ Placer \\
\hline Lines, Lester & North Fork Harrison & Circle & $\mathrm{O} / \mathrm{P}$ Placer \\
\hline Loud, Richard & Harrison & Circle & $\mathrm{O} / \mathrm{P}$ Placer \\
\hline
\end{tabular}




\begin{tabular}{|c|c|c|c|}
\hline Operator & Creek & District & Type $^{\mathrm{a}}$ \\
\hline Olsen, Steven & Eagle & Circle & O/P Placer \\
\hline Smith, David Jr. & Switch/Deadwood & Circle & $\mathrm{O} / \mathrm{P}$ Placer \\
\hline Stone, James & Porcupine & Circle & $\mathrm{O} / \mathrm{P}$ Placer \\
\hline Willis Mine Service & Circle & Circle & O/P Placer \\
\hline Wilkenson, Fred & Ketchem & Circle & $\mathrm{O} / \mathrm{P}$ Placer \\
\hline Wrede, Ronald & Switch & Circle & $\mathrm{O} / \mathrm{P}$ Placer \\
\hline Jensen, Dan & McCumber & Delta River & O/P Placer \\
\hline Andresen, John & Dome & Fairbanks & O/P Placer \\
\hline Bergman, Kevin & Ester & Fairbanks & O/P Placer \\
\hline Cornelius, Fred & Fox & Fairbanks & O/P Placer \\
\hline DeGraaf, Larry & Fox & Fairbanks & O/P Placer \\
\hline Fairbanks Gold Mining Inc. & Fort Knox Mine & Fairbanks & $\mathrm{H} / \mathrm{R} \mathrm{O} / \mathrm{P}$ (gold) \\
\hline Gavora, Steve & Fairbanks & Fairbanks & $\mathrm{O} / \mathrm{P}$ Placer \\
\hline Goodwin, Robert & Twin & Fairbanks & O/P Placer \\
\hline Hassel, Jerry & Ready Bullion & Fairbanks & O/P Placer \\
\hline Hopen, Alf & Cleary & Fairbanks & O/P Placer \\
\hline Jobaric Enterprises & Wildcat & Fairbanks & $\mathrm{O} / \mathrm{P}$ Placer \\
\hline Knudsen, Richard & Specimen & Fairbanks & $\mathrm{O} / \mathrm{P}$ Placer \\
\hline Largent, Walter & Ester & Fairbanks & $\mathrm{O} / \mathrm{P}$ Placer \\
\hline Las, Allen & No Grub & Fairbanks & $\mathrm{O} / \mathrm{P}$ Placer \\
\hline Miscovich, Andy & Wolf & Fairbanks & O/P Placer \\
\hline Moore, Roger & Ready Bullion & Fairbanks & O/P Placer \\
\hline Polar Mining & Fox Goldstream & Fairbanks & $\mathrm{O} / \mathrm{P}$ Placer \\
\hline Roman, Ron & Last Chance & Fairbanks & $\mathrm{O} / \mathrm{P}$ Placer \\
\hline Stein, Don & Gilmore & Fairbanks & $\mathrm{O} / \mathrm{P}$ Placer \\
\hline Thurman Oil \& Mining & Fairbanks & Fairbanks & O/P Placer \\
\hline 45-Pup Mining & Fortymile & Fortymile & O/P Placer \\
\hline Bickell, Harvey & Walker Fork & Fortymile & $\mathrm{O} / \mathrm{P}$ Placer \\
\hline Bras, Cy & Canyon & Fortymile & $\mathrm{O} / \mathrm{P}$ Placer \\
\hline Burns, John & Davis & Fortymile & O/P Placer \\
\hline Carr, Brad & Chicken & Fortymile & $\mathrm{O} / \mathrm{P}$ Placer \\
\hline Edgerton, Judd & Napoleon & Fortymile & O/P Placer \\
\hline GeoQuest & Chicken & Fortymile & O/P Placer \\
\hline Gurule, Dave & Ingle & Fortymile & $\mathrm{O} / \mathrm{P}$ Placer \\
\hline Hanks, G.A. & Lost Chicken & Fortymile & O/P Placer \\
\hline Hayden, Forest & Kal & Fortymile & O/P Placer \\
\hline Heflinger, Fred & Walker Fork & Fortymile & $\mathrm{O} / \mathrm{P}$ Placer \\
\hline Kukowski, Dave & Mosquito Fork & Fortymile & $\mathrm{O} / \mathrm{P}$ Placer \\
\hline Leach, James & Fortymile & Fortymile & O/P Placer \\
\hline Likens, David & Fortymile & Fortymile & O/P Placer \\
\hline Maxwell Mining & Kal / Squaw & Fortymile & $\mathrm{O} / \mathrm{P}$ Placer \\
\hline Mitchell, Harold & Mosquito Fork & Fortymile & $\mathrm{O} / \mathrm{P}$ Placer \\
\hline Mitchell, Joseph & Fortymile & Fortymile & O/P Placer \\
\hline Mitchell, Paul & Eagle & Fortymile & O/P Placer \\
\hline Nevers, Harold & American & Fortymile & O/P Placer \\
\hline Owen, Jeff & Davis & Fortymile & O/P Placer \\
\hline Olsen, Gordon & Jack Wade & Fortymile & $\mathrm{S} / \mathrm{D}$ \\
\hline Olson, Hart & Wade & Fortymile & $\mathrm{O} / \mathrm{P}$ Placer \\
\hline Olsen, Stephen & Liberty & Fortymile & O/P Placer \\
\hline Reed, Scott & Fortymile & Fortymile & O/P Placer \\
\hline Regner, Leo & Lilliwig & Fortymile & O/P Placer \\
\hline Roberts, Robert & Chicken & Fortymile & $\mathrm{S} / \mathrm{D}$ \\
\hline Schene, Earl & Uhler & Fortymile & $\mathrm{O} / \mathrm{P}$ Placer \\
\hline Schofield, Walter & Fortymile & Fortymile & O/P Placer \\
\hline Seuffert, George Jr. & Chicken & Fortymile & $\mathrm{O} / \mathrm{P}$ Placer \\
\hline Thurneau, Vernon & Fortymile & Fortymile & $\mathrm{O} / \mathrm{P}$ Placer \\
\hline
\end{tabular}

${ }^{\mathrm{a}} \mathrm{O} / \mathrm{P}=$ Open-pit; HR=Hard-rock; $\mathrm{U} / \mathrm{G}=$ Underground; $\mathrm{S} / \mathrm{D}=$ Suction Dredge. 


\begin{tabular}{|c|c|c|c|}
\hline Operator & Creek & District & Type $^{\mathbf{a}}$ \\
\hline Treesh, James & Cherry/No Name & Fortymile & $\mathrm{O} / \mathrm{P}$ Placer \\
\hline Wolff, Flint & Walker Fork & Fortymile & $\mathrm{O} / \mathrm{P}$ Placer \\
\hline De Lima Placers & American & Hot Springs & $\mathrm{O} / \mathrm{P}$ Placer \\
\hline Hodges, Jay & American & Hot Springs & O/P Placer \\
\hline Ott, Richard & Omega & Hot Springs & O/P Placer \\
\hline Wilder, Richard & Boulder & Hot Springs & $\mathrm{O} / \mathrm{P}$ Placer \\
\hline Wood, James & Little Boulder & Hot Springs & O/P Placer \\
\hline Eaves, Samuel & Warwick Gulch & Tolovana & $\mathrm{O} / \mathrm{P}$ Placer \\
\hline \multicolumn{4}{|c|}{ SouthCENTRAL Region } \\
\hline Crow Creek Mining & Crow & Anchorage & O/P Placer \\
\hline Girdwood Mining Co. & Crow & Anchorage & $\mathrm{O} / \mathrm{P}$ Placer \\
\hline Hoffman Mining & Chistochina & Chistochina & $\mathrm{O} / \mathrm{P}$ Placer \\
\hline Holt, Ryan & Quartz & Hope & $\mathrm{S} / \mathrm{D}$ \\
\hline Mastel, Fred & Quartz & Hope & O/P Placer \\
\hline Outsider Mining (John Trautner) & Canyon & Hope & $\mathrm{O} / \mathrm{P}$ Placer \\
\hline Willard, Gerald & Bear & Hope & $\mathrm{S} / \mathrm{D}$ \\
\hline Miller, Jerry & Willow/Homestake & Willow Creek & $\mathrm{O} / \mathrm{P}$ Placer \\
\hline Mrak Placer Mine & Willow & Willow Creek & $\mathrm{O} / \mathrm{P}$ Placer \\
\hline Kragness, Sonny & Cache & Yentna & O/P Placer \\
\hline LaCross, Jack & Willow & Yentna & $\mathrm{O} / \mathrm{P}$ Placer \\
\hline Lake Creek Placers & Lake & Yentna & $\mathrm{O} / \mathrm{P}$ Placer \\
\hline \multicolumn{4}{|c|}{ SOUTHWESTERN REGION } \\
\hline Chase Bros & Flat & Anvik & O/P Placer \\
\hline Matter, Mark & Marvel & Aniak & $\mathrm{O} / \mathrm{P}$ Placer \\
\hline Nyac Placer & Bear & Aniak & O/P Placer \\
\hline Wilmarth, Richard & Chicken & Iditarod & O/P Placer \\
\hline Clarke-Wiltz & Podesie/Ganes & Innoko & $\mathrm{O} / \mathrm{P}$ Placer \\
\hline Little Creek & Little & Innoko & $\mathrm{O} / \mathrm{P}$ Placer \\
\hline Lyman Resources & Queen & Innoko & $\mathrm{O} / \mathrm{P}$ Placer \\
\hline Plano, Ed & Anvil & Innoko & O/P Placer \\
\hline Roberts, Bob & Boob & Innoko & O/P Placer \\
\hline \multicolumn{4}{|c|}{ SOUTHEASTERn REGION } \\
\hline Big Nugget Mine & Porcupine & Juneau & O/P Placer \\
\hline Kennecott/Hecla & Greens Creek Mine & Admiralty Island & U/G (zinc-lead-silver-gold) \\
\hline
\end{tabular}

${ }^{\mathrm{a}} \mathrm{O} / \mathrm{P}=$ Open-pit; HR=Hard-rock; $\mathrm{U} / \mathrm{G}=$ Underground; $\mathrm{S} / \mathrm{D}=$ Suction Dredge.

to the inability to contact some placer miners, the estimate for placer mine production is thought to be conservative. Conversely, there may also be some operations listed in table 10 that elected not to mine due to the low price of gold and the high cost of fuel.

The authors also wish to thank the Alaska Railroad Corp., the Alaska Mental Health Trust Land Office, the Alaska Department of Transportation \& Public Facilities, the Alaska Division of Mining, Land, \& Water, the U.S. Bureau of Land Management, and the U.S. Forest Service for providing information for this section of the report.

Some respondents reported costs and unit values, but in general metal values were computed from weekly averages on the London Metal Exchange, and do not take into account mining, shipping, smelting, and other costs incurred by the reporting company.
Tables 12 and 13 show the gold production by region of the state, and the placer production by small, medium, and large operations. Hardrock gold production increased from 527,803 ounces in 2001 to 539,713 ounces in 2002, and placer production decreased marginally from 22,841 ounces in 2001 to 22,381 ounces in 2002. This decrease is much smaller than in the past four years, and production in 2003 is expected to increase, in part because of the rising gold price, and also because of renewed production at Nolan Creek underground placer mine.

Tables 14 and 15 show the value and regional importance of sand, gravel, and rock production. Production of sand and gravel in 2002 was 22.4 million tons, more than twice as much as in 2001, and rock production of 3.2 million tons in 2002 was a marginal increase from the 3.1 million ton production of a year earlier. 
Coal production from Usibelli Coal Mine in 2002 was 1.16 million tons, down from 1.54 million tons in 2001. Only 311,000 tons was exported.

\section{NORTHERN REGION}

At Red Dog Mine near Kotzebue in northwestern Alaska, 3,489,600 tons of ore were milled, down 71,000 tons from the year before. However, the Mill Optimization Project of past years resulted in production of a record $1,366,480$ tons of concentrate with 637,800 tons of contained zinc and 118,880 tons of contained lead, and an estimated 6.75 million ounces of silver (table 16). The ore grade was 21.1 percent zinc, 5.4 percent lead, and 2.7 ounces per ton silver. Despite the higher grade of ore and better recovery, the average price of zinc in 2002 ( $\$ 0.35$ per pound) was so much lower than the 2002 average ( $\$ 0.40$ per pound) that the mine reported a loss of \$28 million for the year. In July 2002 Red Dog employed 521 regular employees and 59 temporary or casual employees, for a total of 580 . Of these, 59 percent were shareholders of the NANA Regional Corp.

Placer gold production was reported from nine placer mines in the northern region, most of them in the Koyukuk drainage around Wiseman. The largest mine in the area, Nolan Mine of Silverado Mines (U.S.) Inc. did not sluice in 2002, but was under development.

Production of sand and gravel in the northern region in 2002 was 2.24 million tons, about the same amount that was used in 2001. Most of the material was used by the major oil companies (British Petroleum and Conoco-Phillips), and was extracted from several existing gravel pits such as Put 23, Milne Point, Duck Island, and the Kuparuk Deadarm, and pits $\mathrm{C}, \mathrm{E}$, and F. Smaller quantities were used by some of the oilfield service companies (Veco, A.I.C., Peak Oilfield Service), and by the North Slope Borough.

The only rock produced and used in this region in 2002 was near Red Dog Mine.

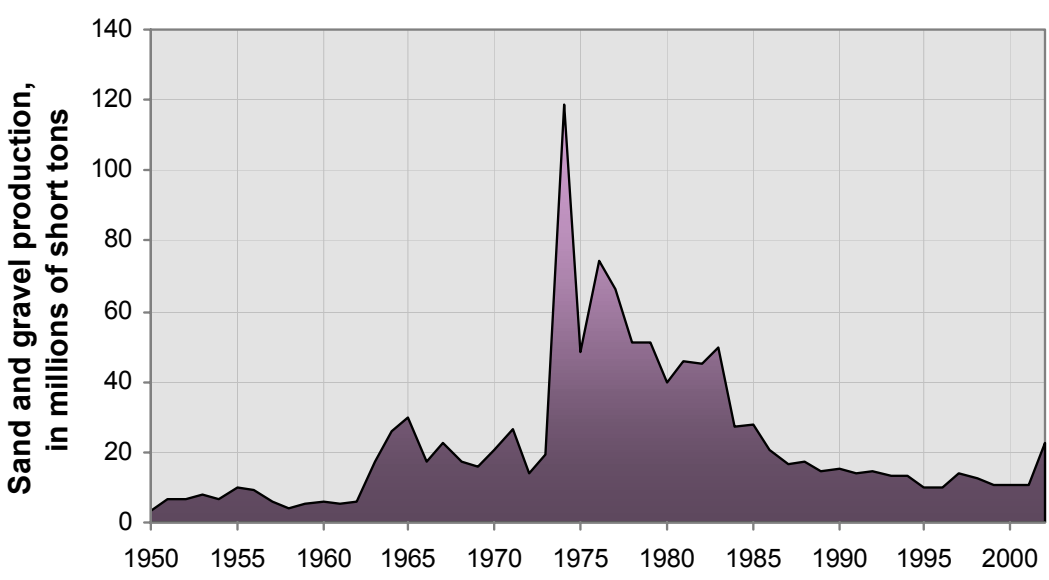

Figure 11. Sand and gravel production in Alaska, 1950-2002.

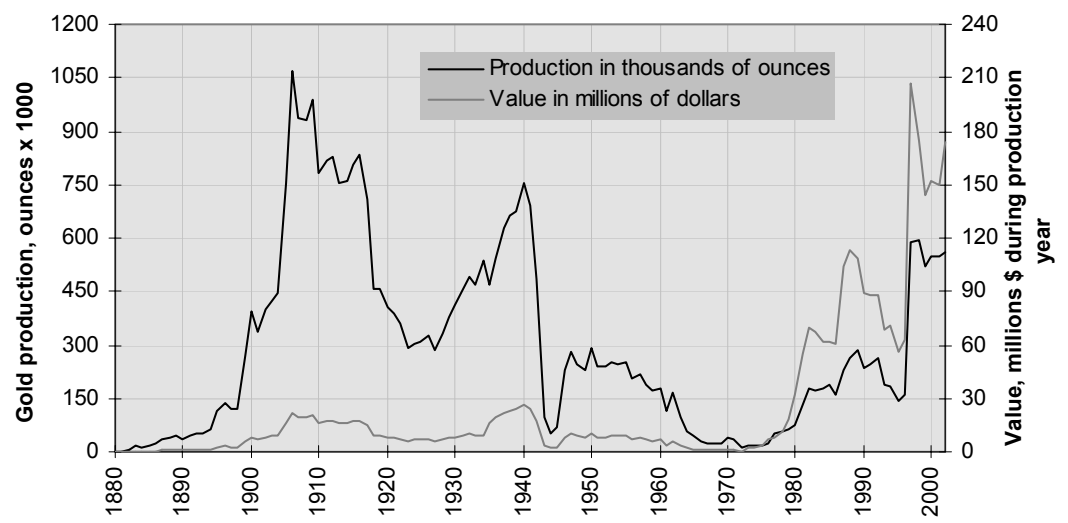

Figure 12. Amount and value of gold production in Alaska, 1880-2002.

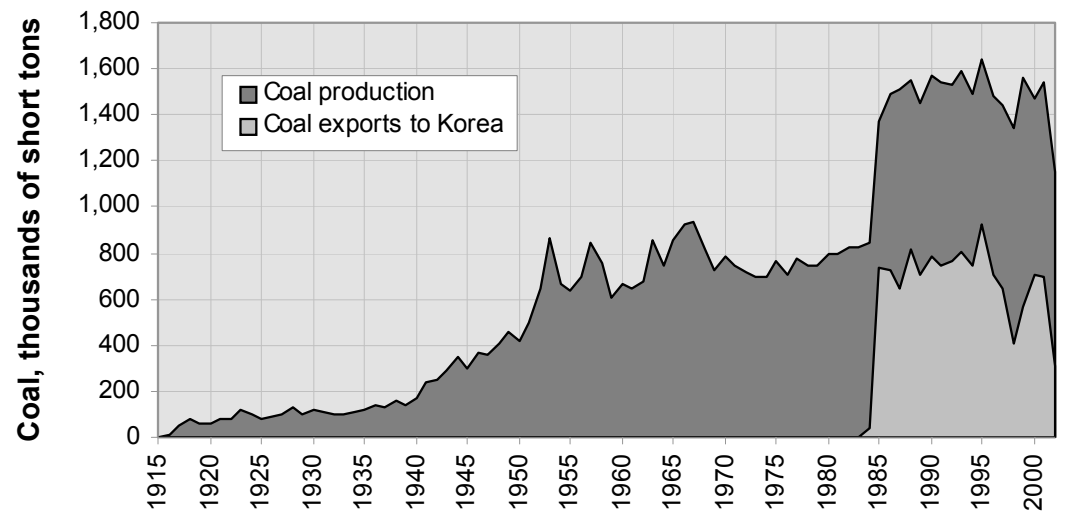

Figure 13. Coal production in Alaska, 1915-2002, including exports to Korea. 


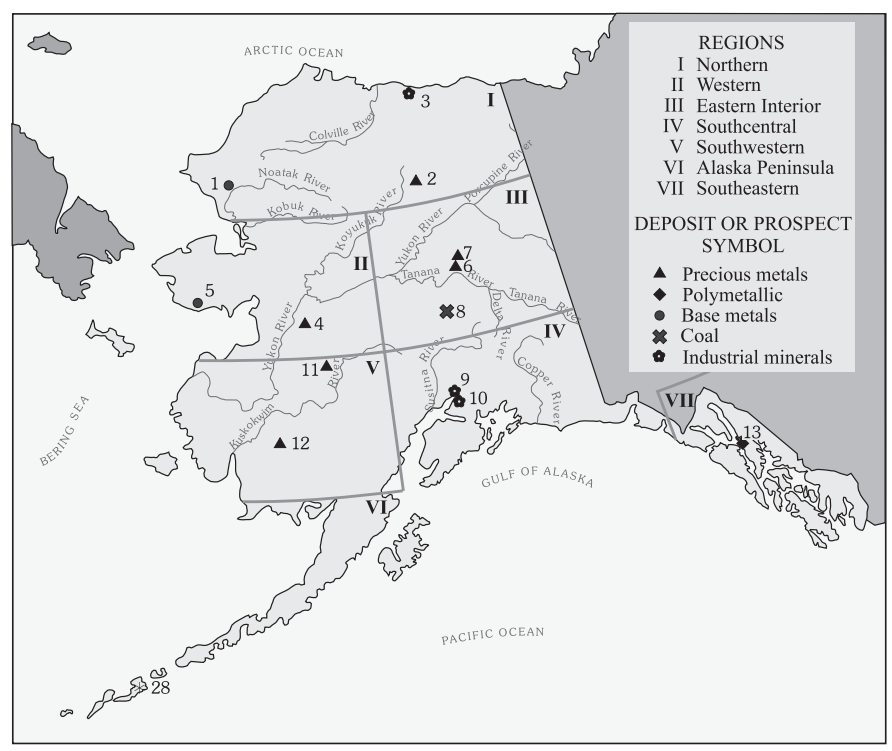

Figure 14. Selected production projects, 2002.

Table 11. Average metal prices, 1993-2002

\begin{tabular}{lccccc}
\hline & $\begin{array}{c}\text { Gold } \\
\mathbf{( \$ / o z )}\end{array}$ & $\begin{array}{c}\text { Silver } \\
\mathbf{( \$ / o z )}\end{array}$ & $\begin{array}{c}\text { Copper } \\
\mathbf{( \$ / l b )}\end{array}$ & $\begin{array}{c}\text { Zinc } \\
\mathbf{( \$ / l b )}\end{array}$ & $\begin{array}{c}\text { Lead } \\
\mathbf{( \$ / l b )}\end{array}$ \\
1993 & 359.00 & 4.30 & 0.87 & 0.44 & 0.18 \\
1994 & 386.00 & 5.41 & 1.05 & 0.45 & 0.35 \\
1995 & 395.00 & 5.43 & 1.33 & 0.48 & 0.34 \\
1996 & 387.60 & 5.19 & 1.03 & 0.49 & 0.37 \\
1997 & 330.76 & 4.91 & 1.03 & 0.59 & 0.28 \\
1998 & 293.88 & 5.53 & 0.75 & 0.46 & 0.24 \\
1999 & 278.70 & 5.20 & 0.71 & 0.49 & 0.23 \\
2000 & 279.10 & 4.96 & 0.82 & 0.51 & 0.21 \\
2001 & 271.04 & 4.37 & 0.71 & 0.40 & 0.22 \\
2002 & 310.06 & 4.61 & 0.71 & 0.35 & 0.21 \\
\hline
\end{tabular}

\section{Northern Region}

1. Cominco Alaska Inc. Red Dog Mine, Noatak district-zinc-lead-silver (germanium)

2. Gold Placer Mines - gold

3. Prudhoe Bay and Kuparuk pits (numerous) sand and gravel

\section{Western Region}

4. American Reclamation Group LLC Illinois Creek Mine, Koyukuk-Hughes districtgold-silver

5. Nome - placer gold, sand and gravel

\section{Eastern Interior Region}

6. Polar Mining Inc., Fairbanks district—goldsilver-screened aggregate

7. Kinross Gold Corp. Fort Knox Mine, True North Mine, Fairbanks district-gold-silver; placer mines

8. Usibelli Coal Mine Inc., Bonnifield districtcoal

\section{Southcentral Region}

9. Landscape Supply Corp., Hatcher Pass district-topsoil-peat

10. Palmer-Anchorage district — sand and gravel

\section{Southwestern Region}

11. Clark-Wiltz Partnership, Innoko districtgold-silver

12. NYAC Mining Co., Nyac district-goldsilver

\section{Alaska Peninsula Region}

\section{Southeastern Region}

13. Kennecott Minerals Co./Hecla Mining Co., Greens Creek Mine, Juneau-Admiralty district-silver-zinc-gold-lead-copper

Table 12. Reported refined gold production, number of operators, and industry employment in Alaska, $2000-2002^{a}$

\begin{tabular}{|c|c|c|c|c|c|c|c|c|c|}
\hline \multirow[t]{2}{*}{ Region } & \multicolumn{3}{|c|}{ Number of operators } & \multicolumn{3}{|c|}{ Production in ounces of gold } & \multicolumn{3}{|c|}{ Number of employees } \\
\hline & 2000 & 2001 & 2002 & 2000 & 2001 & 2002 & 2000 & 2001 & 2002 \\
\hline Northern & 17 & 11 & 9 & 1,434 & 631 & 685 & 11 & 9 & 16 \\
\hline Western & 44 & 10 & 8 & 22,603 & 36,590 & 35,465 & 40 & 55 & 63 \\
\hline Eastern Interior & 76 & 23 & 22 & 392,862 & 423,699 & 421,364 & 394 & 425 & 415 \\
\hline Southcentral & 9 & 5 & 3 & 524 & 484 & 153 & 8 & 10 & 11 \\
\hline Southwestern & 8 & 5 & 6 & 5,650 & 1,386 & 1,733 & 8 & 12 & 14 \\
\hline Southeastern & 2 & 2 & 2 & 128,909 & 87,854 & 102,694 & 280 & 280 & 281 \\
\hline TOTAL & 156 & 56 & 50 & 551,982 & 550,644 & 562,094 & 741 & 791 & 800 \\
\hline
\end{tabular}

a2002 production includes 539,713 ounces gold from Illinois Creek, Fort Knox, and Greens Creek hardrock projects, and 22,381 ounces of placer gold. 
Table 13. Production for selected Alaska placer gold mines, 1996-2002

\begin{tabular}{|c|c|c|c|c|c|c|c|}
\hline Mine size & 1996 & 1997 & 1998 & 1999 & 2000 & 2001 & 2002 \\
\hline \multicolumn{8}{|c|}{ Number of mines } \\
\hline Smalla $^{\mathrm{a}}$ & 9 & 25 & 45 & 38 & 60 & 33 & 43 \\
\hline Medium $^{b}$ & 5 & 6 & 11 & 13 & 14 & 5 & 4 \\
\hline Large $^{c}$ & 4 & 4 & 7 & 7 & 4 & 4 & 2 \\
\hline TOTAL & 18 & 35 & 63 & 58 & 78 & 42 & 49 \\
\hline \multicolumn{8}{|c|}{ Production in ounces } \\
\hline Smalla $^{\mathrm{a}}$ & 1,433 & 5,077 & 10,159 & 4,710 & 8,981 & 5,048 & 9,931 \\
\hline Medium $^{\mathrm{b}}$ & 5,058 & 9,373 & 12,833 & 13,218 & 15,186 & 6,234 & 4,739 \\
\hline Large $^{c}$ & 49,240 & 65,682 & 72,307 & 52,300 & 22,147 & 11,559 & 7,711 \\
\hline TOTAL & 55,731 & 80,132 & 95,299 & 70,228 & 46,314 & 22,841 & 22,381 \\
\hline
\end{tabular}

$\mathrm{a}_{<}<650$ oz gold/yr.

b $650-2,500 \mathrm{oz}$ gold/yr.

c $>2,500$ oz gold/yr.

Table 14. Reported sand and gravel production and industry employment in Alaska by region, 2002

\begin{tabular}{lrrrrr}
\hline Region & $\begin{array}{c}\text { Companies and } \\
\text { agencies reporting }\end{array}$ & Tons & $\begin{array}{c}\text { Estimated unit } \\
\text { value (\$/ton) }\end{array}$ & $\begin{array}{r}\text { Total } \\
\text { value }\end{array}$ & $\begin{array}{c}\text { Estimated number } \\
\text { of employees }\end{array}$ \\
Northern & 9 & $2,242,000$ & 4.59 & $10,291,000$ & 105 \\
Western & 3 & $1,062,000$ & 5.74 & $6,096,000$ & 62 \\
Eastern Interior & 11 & $6,163,000$ & 5.14 & $31,678,000$ & 194 \\
Southcentral & 22 & $10,038,000$ & 5.20 & $52,198,000$ & 258 \\
Southwestern & 6 & $2,523,000$ & 6.90 & $17,409,000$ & 42 \\
Alaska Peninsula & 2 & 36,000 & 7.20 & 259,000 & 4 \\
Southeastern & 5 & 348,000 & 7.95 & $2,767,000$ & 37 \\
TOTAL & $\mathbf{5 8}$ & $\mathbf{2 2 , 4 1 2 , 0 0 0}$ & $\mathbf{5 . 3 9}$ & $\mathbf{\$ 1 2 0 , 6 9 8 , 0 0 0}$ & $\mathbf{7 0 2}$ \\
\hline
\end{tabular}

${ }^{a}$ From 34 returned questionnaires and 14 phone canvass responses. Also includes data from the Alaska Railroad, Department of Transportation, Division of Mining, Land \& Water, U.S. Forest Service, and U.S. Bureau of Land Management.

bValues are based on price and cost estimates from 21 producers.

${ }^{c}$ Weighted average unit value (\$/ton) of sand and gravel production in Alaska.

Table 15. Reported rock production and industry employment in Alaska by region, 2002 ${ }^{a}$

\begin{tabular}{|c|c|c|c|c|c|}
\hline Region & $\begin{array}{c}\text { Companies and } \\
\text { agencies reporting }\end{array}$ & Tons & $\begin{array}{l}\text { Estimated unit } \\
\text { value }(\$ / \text { ton })^{\mathrm{c}}\end{array}$ & $\begin{array}{l}\text { Total } \\
\text { value }\end{array}$ & $\begin{array}{c}\text { Estimated number } \\
\text { of employees }\end{array}$ \\
\hline Northern & 2 & 43,000 & 7.32 & 315,000 & 7 \\
\hline Western & 2 & 15,000 & 7.01 & 105,000 & 5 \\
\hline Eastern Interior & 8 & 828,000 & 8.65 & $7,162,000$ & 41 \\
\hline Southcentral & 9 & $1,259,000$ & 8.25 & $10,387,000$ & 63 \\
\hline Southwestern & 3 & 215,000 & 16.25 & $3,494,000$ & 17 \\
\hline Alaska Peninsula & 2 & 3,000 & 12.77 & 38,000 & 7 \\
\hline Southeastern & 4 & 789,000 & 12.60 & $9,941,000$ & 37 \\
\hline TOTAL & 30 & $3,152,000$ & $9.98^{d}$ & $\$ 31,442,000$ & 177 \\
\hline
\end{tabular}

ancludes shot rock, crushed stone, D-1, riprap, and modest quantities of ornamental stone.

${ }^{b}$ Derived from 23 questionnaires, 13 phone canvass responses. Also includes data from the Alaska Railroad, Department of Transportation, Division of Mining, Land \& Water, U.S. Forest Service, and U.S. Bureau of Land Management.

cUnit value based on data supplied by 18 operations. Unit values for different stone products vary widely.

${ }^{\mathrm{d}}$ Weighted average unit value (\$/ton) of rock production in Alaska. 
Table 16. Red Dog Mine production statistics, 1989-2002 ${ }^{a}$

\begin{tabular}{|c|c|c|c|c|c|c|c|c|c|}
\hline & \multirow[b]{2}{*}{$\begin{array}{c}\text { Tons } \\
\text { Milled }\end{array}$} & \multicolumn{3}{|c|}{ Ore Grade } & \multirow{2}{*}{$\begin{array}{c}\text { Total Tons } \\
\text { Concentrate } \\
\text { Produced }^{c}\end{array}$} & \multirow{2}{*}{$\begin{array}{c}\text { Contained } \\
\text { Tons } \\
\text { Zinc }\end{array}$} & \multirow{2}{*}{$\begin{array}{c}\text { Contained } \\
\text { Tons } \\
\text { Lead }\end{array}$} & \multirow{2}{*}{$\begin{array}{l}\text { Million } \\
\text { Ounces } \\
\text { Silver }^{b}\end{array}$} & \multirow[b]{2}{*}{ Employees } \\
\hline & & $\begin{array}{c}\text { Zinc } \\
\%\end{array}$ & $\begin{array}{c}\text { Lead } \\
\%\end{array}$ & $\begin{array}{l}\text { Silver } \\
\text { oz/ton }\end{array}$ & & & & & \\
\hline 1989 & 33,300 & 20.4 & 7.6 & 3.6 & 8,532 & - & -- & - & 228 \\
\hline 1990 & 996,700 & 26.5 & 8.5 & 3.6 & 443,600 & 191,981 & 31,187 & -- & 350 \\
\hline 1991 & $1,599,300$ & 22.5 & 6.6 & 2.8 & 521,400 & 234,510 & 43,815 & - - & 331 \\
\hline 1992 & $1,582,000$ & 19.9 & 6.0 & 2.9 & 474,900 & 231,363 & 15,960 & -- & 349 \\
\hline 1993 & $1,874,600$ & 18.4 & 5.7 & 2.8 & 539,800 & 255,149 & 24,788 & -- & 376 \\
\hline 1994 & $2,339,500$ & 18.8 & 5.7 & 2.8 & 658,000 & 328,160 & 32,775 & -- & 391 \\
\hline 1995 & $2,485,900$ & 19.0 & 5.8 & 2.8 & 753,600 & 358,676 & 55,715 & 3.615 & 397 \\
\hline 1996 & $2,312,600$ & 18.7 & 5.0 & 2.8 & 765,300 & 357,680 & 65,886 & 4.304 & 417 \\
\hline 1997 & $2,127,000$ & 20.3 & 5.2 & 2.9 & 799,400 & 373,097 & 69,284 & 4.273 & 479 \\
\hline 1998 & $2,752,587$ & 21.4 & 5.2 & 2.7 & $1,015,773$ & 490,461 & 80,193 & 5.202 & 466 \\
\hline 1999 & $3,282,788$ & 21.3 & 5.2 & 2.7 & $1,207,160$ & 574,111 & 97,756 & 6.205 & 539 \\
\hline 2000 & $3,365,508$ & 21.0 & 4.7 & 2.5 & $1,211,539$ & 585,030 & 91,557 & 5.843 & 536 \\
\hline 2001 & $3,560,430$ & 19.8 & 5.0 & 2.5 & $1,215,837$ & 570,980 & 105,000 & 5.898 & 559 \\
\hline 2002 & $3,489,600$ & 21.1 & 5.4 & 2.7 & $1,366,480$ & 637,800 & 118,880 & 6.750 & 560 \\
\hline
\end{tabular}

aRevised slightly from Special Report 50, Alaska's Mineral Industry 1995 (Bundtzen and others), based on new company data.

${ }^{b}$ Estimate based on grade and tonnage.

${ }^{\mathrm{c}}$ Totals for years 1990 through 1995 include bulk concentrate.

- - = No data.

Source: Gary Coulter, Jim Kulas, Bob Robinson, and Garth Elsdon, Teck Cominco Alaska Inc.

\section{WESTERN REGION}

American Reclamation Group LLC continued leaching gold at Illinois Creek Mine from 385,000 tons of ore added to the existing heaps, and conducted a limited exploration program designed to prospect for the northward extension of the vein in the East Pit (fig. 15). The mine employs 53 workers, many from the nearby villages of Ruby, Galena, Huslia, Kaltag, and Nulato.

Eight placer gold mines reported production in the western region in 2002, and collectively produced 8,965 ounces of refined gold.
The only reported use of sand and gravel in the western region in 2002 was around Nome on the Seward Peninsula, and most was derived from washed tailings from NovaGold Resources’ placer mines.

\section{EASTERN INTERIOR REGION}

Fairbanks Gold Mining Inc. (FGMI), a subsidiary of Kinross Gold Corp., is the operator of Fort Knox Mine and the satellite True North Mine about 25 miles north of Fairbanks. During 2002, with a workforce of 360, FGMI recovered 410,519 ounces of gold from the 15.26 million tons of ore milled (table 17). The ore was derived from 11.5 million tons of rock mined at True North, and 24.5 million tons mined at Fort Knox.

Placer mining has long been the backbone of the mining industry in interior Alaska, and there were about 25 mines working in 2002, despite the low gold price. Total production from these mines in 2002 was 10,845 ounces, down 13 percent from the 12,479 ounces reported for 2001.

Figure 15. Illinois Creek Mine's East Pit. American Reclamation Group LLC continued leaching gold from this stateowned mineral resource near Galena. Photo by Dick Swainbank. 
The total amount of coal mined from Usibelli Coal Mine (UCM) near Healy in 2002 was $1,157,879$ tons, considerably less than in past years. The reason for the decline was the expiration of its coal export contract with the Korean Electric Power Co., (KEPCO). UCM was forced to lay off 40 of its 120 employees during 2002. The mine did continue shipping coal to Korea through September to fulfill existing contract obligations, but the total of 310,646 tons shipped for 2002 was down substantially from prior years. Since the first shipment in 1984, UCM has shipped 12.4 million tons of coal to Korea through the port of Seward, providing revenue and jobs for the Alaska Railroad, and also for the coal-loading facility in Seward.

Sand and gravel production of 6 million tons in this region in 2002 was mainly for roadwork near Fairbanks and on the Dalton Highway between Fairbanks and Deadhorse. A magnitude 7.9 earthquake in November caused exten-

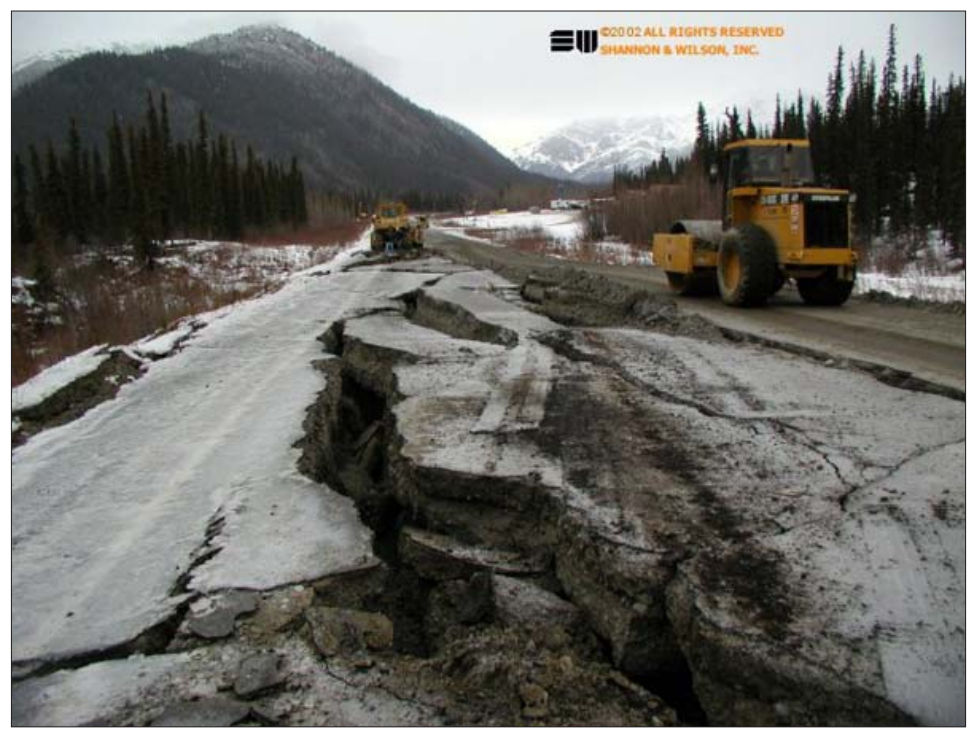

Figure 16. Damaged road surface at milepost 78 along the Tok Cut-off from the magnitude 7.9 Denali fault earthquake of November 3, 2002. View looking north towards Mentasta Lodge on the east (right) side of road. At this location there was approximately 4 feet of vertical and 6 feet of horizontal displacement across road. West (left) side of road also shows the southwestern end of landslide-lateral spread into lake. A Shannon \& Wilson team, including Rohn Abbott, Steve Adamczak, Frank Wuttig, Mark Lockwood, and Bill Perkins, investigated and documented geotechnical damage to Alaska's highways, the Trans-Alaska pipeline, and small villages along the fault following the world's largest earthquake during 2002. Photo provided courtesy of Shannon \& Wilson Inc. from Web site (http://clients.shanwil.net/ project.php? projectid=Fairbanks_Quake_2002). sive road damage in the eastern part of the region, and a considerable amount of rock and gravel was required to complete temporary repairs to the Richardson Highway and the Tok Cutoff (figs. 16 and 17).

\section{SOUTHCENTRAL REGION}

The only metal production in the southcentral region in 2002 was from four small placer gold mines, with a cumulative production of about 153 ounces.

In 2002, the production of sand and gravel in the southcentral region was 8.6 million tons, about half of which was used in road construction on the Kenai Peninsula. Late in the year, flooding on the Kenai required emergency road repair that added to the total.

\section{SOUTHWESTERN REGION}

Placer gold production in the southwestern region in 2002 was reported from six mines.

A small quantity of armor rock was produced from the Bristol Bay Native Corp. quarry near Dillingham, but most of the rock used in the region was from Calista Corp. lands. Sand and gravel for airport upgrades at Chevak and Toksook Bay were derived from local sources. 


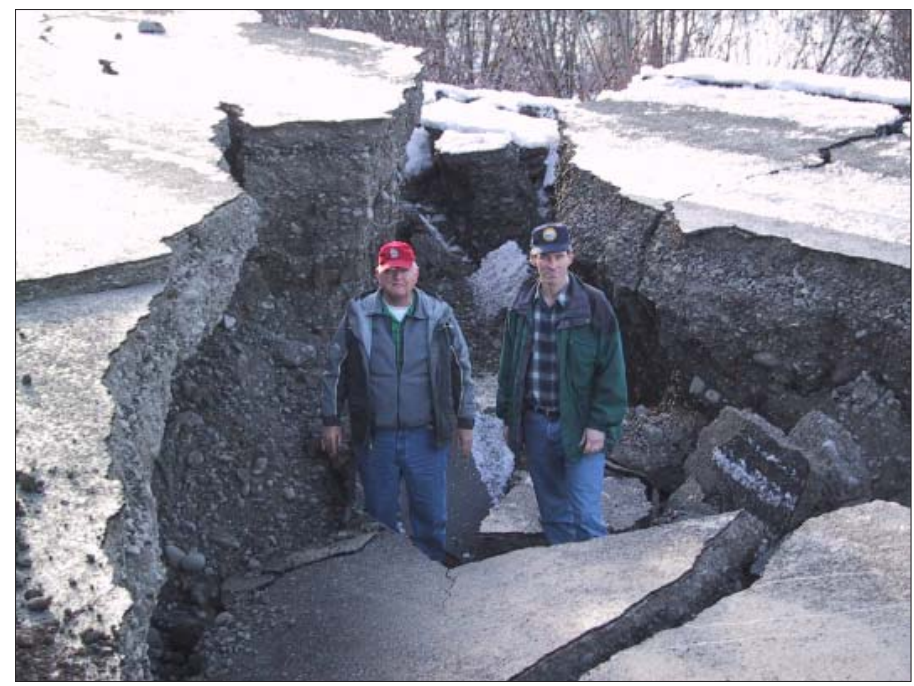

Figure 17. Former DOT Commissioner Joseph Perkins and Maintenance Engineer Frank Richards examine road surface along the Tok Cut-off Highway between mileposts 44 and 91 that was damaged from liquefaction of road base materials during the magnitude 7.9 Denali Earthquake of November 3, 2002. Photo provided by northern region office of the Alaska Department of Transportation \& Public Facilities.

\section{ALASKA PENINSULA REGION}

The only production in the Alaska Peninsula region was a few thousand tons of rock and about 36,000 tons of gravel for local construction at Dillingham and on Kodiak Island.

\section{SOUTHEASTERN REGION}

With a workforce of 262 people, Kennecott Minerals milled a record 733,507 tons of ore in 2002, up 11.5 percent from the 658,000 tons milled in 2001 (table 18). Head grade of the ore was 12.52 percent zinc, 4.73 percent lead, 19.73 ounces per ton silver, and 0.203 ounces per ton of gold. The concentrate contained 80,306 tons of zinc, 27,582 tons of lead, 10,913,183 ounces of silver, and 102,694 ounces of gold. At the beginning of 2003 the proven/probable reserve stood at 7.05 million tons of 11.4 percent zinc, 4.2 percent lead, 14.9 ounces per ton of silver, and 0.13 ounces per ton of gold. Other resources were 2.7 million tons at 11.3 percent zinc, 4.9 percent lead, 17.0 ounces per ton silver, and 0.13 ounces per ton of gold.

Rock production of 789,000 tons in the southeastern region in 2002 was almost twice that of the previous year, but due to low levels of road maintenance by the U.S. Forest Service, well below the levels of a few years ago. The 348,000 tons of sand and gravel produced were used for local road maintenance and concrete mixes.

Table 18. Greens Creek Mine production statistics, 1989-2002

\begin{tabular}{|c|c|c|c|c|c|c|c|c|}
\hline & $\begin{array}{c}\text { Tons } \\
\text { Milled }\end{array}$ & $\begin{array}{c}\text { Tons } \\
\text { Concentrate }\end{array}$ & $\begin{array}{c}\text { Contained } \\
\text { Tons } \\
\text { Zinc }\end{array}$ & $\begin{array}{c}\text { Contained } \\
\text { Tons } \\
\text { Lead }\end{array}$ & $\begin{array}{c}\text { Contained } \\
\text { Ounces } \\
\text { Silver }\end{array}$ & $\begin{array}{c}\text { Contained } \\
\text { Ounces } \\
\text { Gold }\end{array}$ & $\begin{array}{c}\text { Contained } \\
\text { Tons } \\
\text { Copper }\end{array}$ & Employees \\
\hline 1989 & 264,600 & - - & 18,007 & 9,585 & $5,166,591$ & 23,530 & - - & 235 \\
\hline 1990 & 382,574 & - - & 37,000 & 16,728 & $7,636,501$ & 38,103 & - - & 265 \\
\hline 1991 & 380,000 & - - & 41,850 & 16,900 & $7,600,000$ & 37,000 & - - & 238 \\
\hline 1992 & 365,000 & 113,827 & 40,500 & 16,500 & $7,100,000$ & 32,400 & - - & 217 \\
\hline $1993^{\mathrm{a}}$ & 77,780 & - - & 9,500 & 3,515 & $1,721,878$ & 7,350 & - - & 217 \\
\hline 1994 & - - & - & - - & - - & - & - - & - & - - \\
\hline 1995 & - & - - & - - & - - & - & - - & - - & - - \\
\hline $1996^{\mathrm{a}}$ & 135,000 & 43,000 & 9,100 & 4,200 & $2,476,000$ & 7,480 & 193 & 265 \\
\hline 1997 & 493,000 & - - & 46,000 & 19,000 & $9,700,000$ & 56,000 & 1,300 & 275 \\
\hline 1998 & 540,000 & - & 58,900 & 22,700 & $9,500,000$ & 60,572 & 1,300 & 275 \\
\hline 1999 & 578,358 & - - & 68,527 & 25,503 & $10,261,835$ & 80,060 & 1,400 & 275 \\
\hline 2000 & 619,438 & - - & 84,082 & 31,677 & $12,424,093$ & 128,709 & 1,400 & 275 \\
\hline 2001 & 658,000 & - & 63,903 & 22,385 & $10,900,000$ & 87,583 & 1,400 & 275 \\
\hline 2002 & 733,507 & 217,200 & 80,306 & 27,582 & $10,913,183$ & 102,694 & 1,600 & 262 \\
\hline
\end{tabular}

aPart-year production.

- - Not reported. 


\section{DRILLING}

Drilling was conducted during all phases of mining (exploration, development, and production) on various projects across Alaska during 2002. Table 19 lists all companies with significant drill programs in Alaska during 2002. Drilling totals for 2002 are 385,290 feet of core drilling and 103,612 feet of reverse-circulation drilling. Hardrock core (sometimes referred to as hardrock diamond drilling) footage in 2002 is approximately 60 percent higher than the 240,318 feet reported drilled in 2001. Reverse-circulation drilling footage also increased by approximately 37 percent from the 75,750 feet reported drilled in 2001. Hardrock core footage for 2002 is approximately 10 percent lower than the average core footage reported in Alaska from 1996 to 2001. Reverse-circulation drilling footage for 2002 is equal to the average reverse-circulation drilling footage from 1996 to 2001. Drilling at placer mines was largely unreported for 2002, with 1,250 feet reported. Coal drilling is unreported, but likely occurred at Usibelli Coal Mine. Tables 20 and 21 summarize the drilling activity in the state during 2002 by region and type of drilling. The southwestern region had the most drilling of all Alaska regions, with 42 percent of the total for 2002. The eastern interior region had 28 percent of the drilling, followed by the southeastern region with 22 percent. Major drill programs were conducted by NovaGold Resources Inc. at the Donlin Creek deposit (fig. 18), by Northern Dynasty Minerals Ltd. at the Pebble prop-

Table 19. Companies reporting significant drilling programs in Alaska, 2002

\begin{tabular}{lll}
\hline AngloGold (USA) Exploration Inc. & Kinross Gold Corp. & Olympic Resources Group LLC \\
Chapleau Resources Ltd. & Nevada Star Resource Corp. & Quaterra Resources Inc. \\
Golconda Resources Ltd. & North Star Exploration Inc.(EMEX & Rio Fortuna Exploration Co. \\
Hecla Mining Co. & Corp.) & Teck Cominco Ltd. \\
Kennecott Exploration Co. & Northern Dynasty Minerals Ltd. & Teck Pogo Inc. \\
Kennecott Minerals Co. & NovaGold Resources Inc. & TNR Resources Ltd. \\
\hline
\end{tabular}

Table 20. Drilling footage reported in Alaska, 1982-2002

\begin{tabular}{|c|c|c|c|c|c|c|c|c|}
\hline Year & $\begin{array}{c}\text { Placer } \\
\text { Exploration }\end{array}$ & $\begin{array}{c}\text { Placer } \\
\text { Thawing }\end{array}$ & $\begin{array}{c}\text { TOTAL } \\
\text { PLACER }\end{array}$ & $\begin{array}{l}\text { TOTAL } \\
\text { COAL }\end{array}$ & $\begin{array}{c}\text { TOTAL } \\
\text { HARDROCK }\end{array}$ & $\begin{array}{c}\text { Hardrock } \\
\text { Core }^{\mathrm{a}}\end{array}$ & $\begin{array}{c}\text { Hardrock } \\
\text { Rotary }^{\mathrm{a}}\end{array}$ & $\begin{array}{c}\text { TOTAL } \\
\text { FEET }\end{array}$ \\
\hline 1982 & 30,000 & 94,000 & 124,000 & 80,000 & 200,000 & - & -- & 404,000 \\
\hline 1983 & 23,000 & 30,000 & 53,000 & 12,000 & 180,500 & - - & -- & 245,500 \\
\hline 1984 & 31,000 & 98,000 & 129,000 & 25,700 & 176,000 & -- & - - & 330,700 \\
\hline 1985 & 46,000 & 34,000 & 80,000 & 8,700 & 131,700 & - & - & 220,400 \\
\hline 1986 & 32,400 & 227,000 & 259,400 & 28,800 & 50,200 & - - & -- & 338,400 \\
\hline 1987 & 50,250 & 130,000 & 180,250 & 19,900 & 115,100 & 95,600 & 19,500 & 315,250 \\
\hline 1988 & 152,000 & 300,000 & 452,000 & 26,150 & 353,860 & 223,630 & 130,230 & 832,010 \\
\hline 1989 & 97,250 & 210,000 & 307,250 & 38,670 & 332,230 & 242,440 & 89,790 & 678,150 \\
\hline 1990 & 78,930 & 105,000 & 183,930 & 18,195 & 760,955 & 648,600 & 112,355 & 963,080 \\
\hline 1991 & 51,247 & 130,000 & 181,247 & 16,894 & 316,655 & 205,805 & 110,850 & 514,796 \\
\hline 1992 & 6,740 & 65,000 & 71,740 & 12,875 & 359,834 & 211,812 & 148,022 & 444,449 \\
\hline 1993 & 25,216 & - - & 25,216 & - - & 252,315 & 124,325 & 127,990 & 277,531 \\
\hline 1994 & 21,000 & - & 21,000 & 8,168 & 438,710 & 347,018 & 91,692 & 467,878 \\
\hline 1995 & 27,570 & -- & 27,570 & - - & 415,485 & 363,690 & 51,795 & 443,055 \\
\hline 1996 & 61,780 & -- & 61,780 & 8,500 & 658,857 & 524,330 & 134,527 & 729,137 \\
\hline 1997 & 38,980 & -- & 38,980 & 13,998 & 704,510 & 523,676 & 180,834 & 757,488 \\
\hline 1998 & 33,250 & -- & 33,250 & 2,300 & 549,618 & 505,408 & 45,670 & 585,168 \\
\hline 1999 & 6,727 & - & 6,727 & - - & 448,797 & 369,863 & 78,934 & 455,524 \\
\hline 2000 & 15,480 & -- & 15,480 & - - & 546,268 & 418,630 & 127,638 & 561,748 \\
\hline 2001 & 1,100 & -- & 1,100 & 36,151 & 316,068 & 240,318 & 75,750 & 353,319 \\
\hline 2002 & 1,250 & -- & 1,250 & - - & 488,902 & 385,290 & 103,612 & 490,152 \\
\hline
\end{tabular}

${ }^{\mathrm{a}}$ Core and rotary drilling not differentiated prior to 1987.

- - = Not reported.

Note: 500,000 feet of blasthole drilling reported for 2002 (incomplete). 
erty, by Chapleau Resources Ltd. at the Kougarok property, by Kinross Gold Corp. in the Fairbanks mining district including Fort Knox and True North mines, by Teck Pogo Inc. at the Pogo property, and by Kennecott Minerals Co. at Greens Creek Mine.

Figure 18. Drill helper unloads drill samples from core barrel into core boxes at the Donlin Creek gold property. NovaGold had the largest exploration drilling program in Alaska during 2002. Photo courtesy of NovaGold Resources Inc.

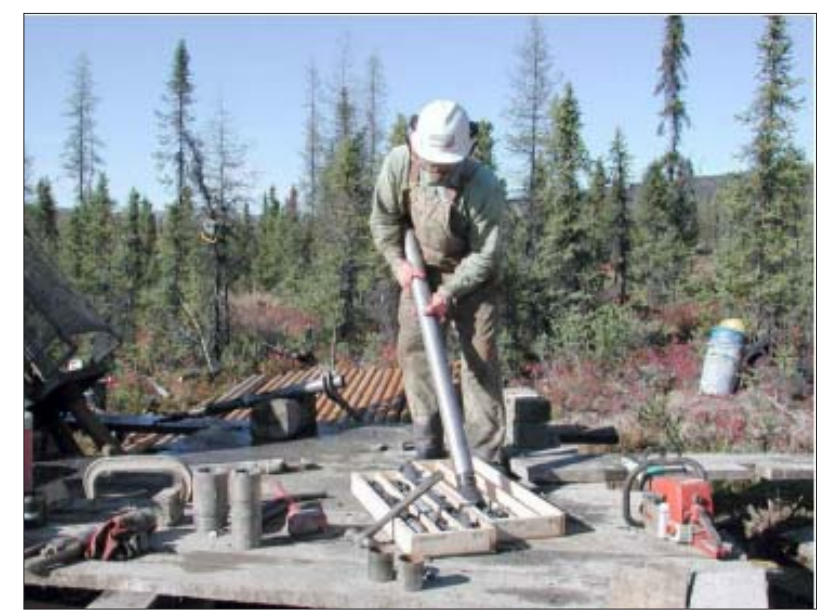

Table 21. Drilling footage by region in Alaska, 2002

\begin{tabular}{|c|c|c|c|c|c|c|c|}
\hline Type of drilling & Northern & Western & $\begin{array}{c}\text { Eastern } \\
\text { interior }\end{array}$ & $\begin{array}{l}\text { South- } \\
\text { central }\end{array}$ & $\begin{array}{l}\text { South- } \\
\text { western }\end{array}$ & $\begin{array}{l}\text { South- } \\
\text { eastern }\end{array}$ & TOTAL \\
\hline Placer subtotal & - - & -- & 1,250 & - - & - - & -- & 1,250 \\
\hline Coal subtotal & -- & -- & - - & - & -- & -- & - - \\
\hline Hardrock core & 7,136 & 20,630 & 74,645 & 7,579 & 165,472 & 109,828 & 385,290 \\
\hline Hardrock rotary & - - & 1,200 & 61,032 & 2,500 & 38,880 & - - & 103,612 \\
\hline Hardrock subtotal & 7,136 & 21,830 & 135,677 & 10,079 & 204,352 & 109,828 & 488,902 \\
\hline TOTAL (feet) & 7,136 & 21,830 & 136,927 & 10,079 & 204,352 & 109,828 & 490,152 \\
\hline
\end{tabular}

- - = Not reported.

Note: 500,000 feet of blasthole drilling reported (incomplete). Drill footages do not include sand and gravel drilling.

\section{GOVERNMENT ACTIONS}

At the end of October, True North Mine received a Sentinels of Safety Award from the federal Mine Safety and Health Administration (MSHA) for 135,554 hours without lost time due to a work injury during the construction and startup of the mine.

Ray Lester received an award from the Alaska Department of Natural Resources for his reclamation activities on Birch Creek in the Circle mining district between 1995 and 2002. The U.S. Bureau of Land Management also received an award from DNR for innovative thinking that considerably reduced costs of reclamation at the Elim project on the Seward Peninsula.

Airborne geophysical surveys funded by the Alaska Division of Geological \& Geophysical Surveys (DGGS) were flown in the Council area east of Nome. DGGS also released results of surveys from three areas flown in 2001: In the area southeast of the Pogo deposit, in the Broad Pass area south of Cantwell, and in the Liberty Bell area east of Healy (table 22).
Magnetic and multi-frequency electromagnetic geophysical surveys funded by the Bureau of Land Management and managed by DGGS were flown in the southern Delta River area (Denali Block) west of Paxson, and in the Red Devil-Sleetmute area of southwestern Alaska. Existing company data were incorporated into the Delta River data and the survey covers about 600 square miles. Publication of the surveys is expected in early 2003. These surveys are the fifth and sixth cooperative airborne geophysical projects between the BLM and DGGS (table 23).

Also in 2002, a strategic 235,000 acres of the Denali Block area, containing some of the best copper-nickelplatinum-group-element (PGE) targets, were Tentatively Approved (TA) for transfer to the State of Alaska from the federal government.

A team of four DGGS geologists, one University of Alaska Fairbanks professor, and two student assistants spent two months mapping in the central Big Delta Quad- 
Table 22. Detailed state airborne geophysical surveys and follow-up geologic ground-truth mapping as of December $2002^{a}$

\begin{tabular}{|c|c|c|}
\hline Nome District western core area & 494 sq. miles & Airborne geophysical/ground-truth geological mapping \\
\hline Nyac District core area & 183 sq. miles & Airborne aeromagnetic mapping \\
\hline Circle District core area & 338 sq. miles & Airborne geophysical mapping/ground-truth geologic map \\
\hline Valdez Creek District & 75 sq. miles & Airborne geophysical mapping \\
\hline Fairbanks District & 626 sq. miles & Airborne geophysical mapping/ground-truth geologic map \\
\hline Richardson District & 137 sq. miles & Airborne geophysical mapping \\
\hline Rampart/Manley-Tofty & 1,017 sq. miles & Airborne geophysical mapping/ground-truth geologic map \\
\hline Upper Chulitna District & 364 sq. miles & Airborne geophysical mapping/ground-truth geologic map \\
\hline Petersville-Collinsville District & 415 sq. miles & Airborne geophysical mapping/ground-truth geologic map \\
\hline Iron Creek District & 689 sq. miles & Airborne geophysical mapping/ground-truth geologic map \\
\hline Ruby District & 591 sq. miles & Airborne geophysical mapping/ground-truth geologic map \\
\hline Fortymile District & 1,036 sq. miles & Airborne geophysical mapping/ground-truth geologic maps \\
\hline Livengood District & 229 sq. miles & Airborne geophysical mapping (ground-truth in 2003) \\
\hline SalchaRiver/North Pogo & 1,032 sq. miles & Airborne geophysical mapping/ground-truth geologic maps \\
\hline Southeast extension of Salcha River/Pogo & 91 sq. miles & Airborne geophysical mapping (released winter 2002) \\
\hline Liberty Bell & 276 sq. miles & Airborne geophysical mapping (released winter 2002) \\
\hline Broad Pass & 304 sq. miles & Airborne geophysical mapping (released winter 2002) \\
\hline Council & 618 sq. miles & Airborne geophysical mapping (to be released winter 2003) \\
\hline Total: 11 years & 8,515 sq. miles & $1.3 \%$ of Alaska's total area \\
\hline
\end{tabular}

aprojects funded by the Alaska State Legislature. Projects concentrate on state, Native, state-selected, and Native-selected lands and are managed by DGGS.

Note: Surveys listed above are complete except where noted. Additional areas will be scheduled for surveying at later dates contingent on future funding.

rangle during 2002. Geologic maps covering approximately 420 square miles in the area of a 2000 DGGS airborne geophysical survey will be published in June 2003. Fieldwork was supplemented by point-counting of feldspar-stained rock slabs, ore-element geochemical analyses, major, minor and trace element analyses, radiometric dating, detailed thin-section petrography, and microprobe analyses.

The U.S. Geological Survey (USGS) conducted studies over several years on the Red Dog deposit and regional setting. Recent results include a possible regional exploration tool for "Red Dog type" massive-sulfide mineralization in Mississippian Kuna shale. Geochemical indications of mineralization include greater than 2 parts per million germanium, greater than 1.2 parts per million thallium, greater than 45 parts per million arsenic, and greater than or equal to 20 parts per million antimony.

During the last two summers, USGS and Calista Native Corp. geologists collected geochemical samples in southwestern Alaska in conjunction with the National Geochemical Survey, a nationwide program designed to establish baseline chemical data in the geologic environment. These data are useful in mineral exploration and environmental studies. More than 350 randomly chosen sample sites were visited in 2001 and 2002. At each site, stream sediment and heavy-mineral concentrate samples were collected for chemical and mineralogical analyses. At many sites, vegetation samples were also collected to evaluate naturally occurring metal uptake by various plant species. In 2002, U.S. Geological Survey geologists also began collecting water samples to study metal concentrations and their transport in surface and subsurface waters in Donlin Creek and the surrounding area. NovaGold Resources hired an independent contractor to conduct similar hydrologic studies on the property. These studies will continue over the next few years to document the natural background concentrations of various metals in the environment prior to future development of a mine at Donlin Creek. This information will be valuable in determining permitting and environmental monitoring requirements at Donlin Creek.

The 2002 USGS program in the northern Talkeetna Mountains and southern Alaska Range, the Talkeetna Mountains Transect Project, included gravity and magnetic geophysical studies. Wrangellia terrane, including 
Table 23. Detailed federal airborne geophysical survey work as of December $2002^{a}$

\begin{tabular}{|c|c|c|}
\hline Wrangell/Stikine ${ }^{b}$ & 1,111 sq. miles & Airborne geophysical mapping \\
\hline Koyukuk/Wiseman & 533 sq. miles & Airborne geophysical mapping \\
\hline Ketchikan ${ }^{\mathrm{c}}$ & 605 sq. miles & Airborne geophysical mapping \\
\hline Aniak & 1,240 sq. miles & Airborne geophysical mapping \\
\hline Delta River & 603 sq. miles & $\begin{array}{l}\text { Airborne geophysical mapping } \\
\text { (to be released 2003) }\end{array}$ \\
\hline Sleetmute & 641 sq. miles & $\begin{array}{l}\text { Airborne geophysical mapping } \\
\text { (to be released 2003) }\end{array}$ \\
\hline Total: 6 years $\$ 2.04$ million & 4,733 sq. miles & $0.5 \%$ of Alaska's total area \\
\hline
\end{tabular}

host rocks for ultramafic intrusions and possible PGE mineralization, was found to be two times larger in area than previously mapped and at least 30 miles wider, according to geophysical study results and models. Geophysical models also show two northeast-trending belts with gravity and magnetic features similar to the ultramafic Fish Lake Complex being explored by Nevada Star Resources. Magnetotelluric studies include a transect through the Amphitheater Mountains that reveal a "Honking Big Anomaly" that is too dense to be a graphitic schist and is interpreted to be a westward-plunging massive-sulfide body.
The BLM conducted a 7-week field program in the southern part of the Delta River mining district of eastern and southcentral Alaska over much of the area covered by the USGS Talkeetna Mountains Transect Project (fig. 19). Field crews visited 108 sites (lode, placer, industrial, and coal) and collected 355 samples (rock chip, placer, pan concentrate, and stream sediment). BLM plans to conduct 2 more years of fieldwork and possibly acquire more airborne geophysical data for the northern part of the district. The BLM's mineral assessment will include mineral occurrence surveying, mapping, and sampling; airborne and ground

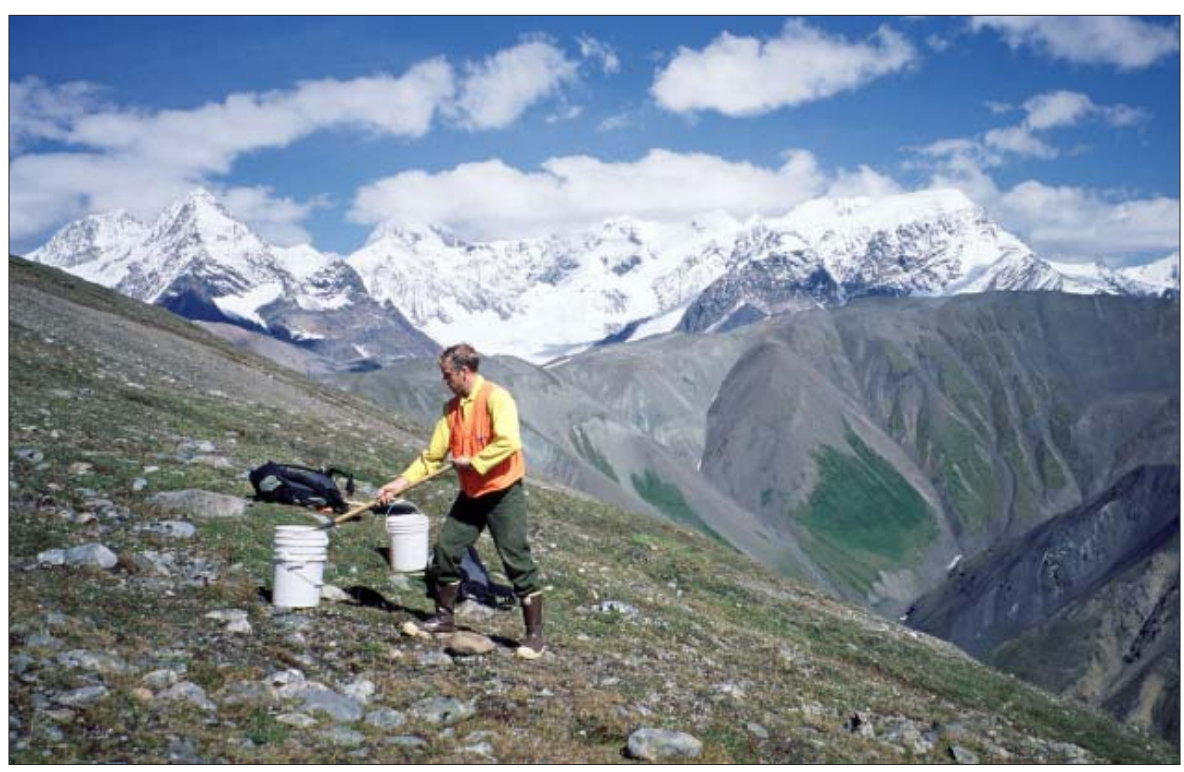

Figure 19. John Wandke, a temporary BLM employee, samples "roundwash" for assessment of potential placer minerals as part of the BLM's mineral assessment of the Delta River mining district. Photo by Joe Kurtak. 
geophysics; stream sediment geochemistry; and economic, engineering, and environmental analysis.

In 2002, Teck Cominco received recognition from the U.S. Coast Guard, with a public commendation to Foss Maritime and the Red Dog mine for their excellent efforts to secure and recover, without environmental incident, a barge that broke loose during a storm at the Red Dog port on the Chukchi Sea. During the year, the company also had to deal with some very difficult situations. A committee from the community of Kivalina near the Red Dog mine brought proceedings against Teck Cominco Alaska alleging violations of the federal Clean Water Act and the mine's water discharge permits. The vast majority of the alleged incidents were permitted through Compliance Orders issued by the EPA, and Teck Cominco Alaska has worked closely with the regulatory authorities and NANA to meet the concerns of the community of Kivalina.

The minerals industry paid almost $\$ 5.5$ million to the State of Alaska in 2002, of which just less than $\$ 0.5$ million was for mining license taxes. The severe drop in mining license taxes, which are based on profitability, resulted from a \$30 million loss for Red Dog Mine. An additional \$9.7 million was paid to municipalities. Mining companies were the largest tax payers in the City and Borough of Juneau and the Fairbanks North Star, Denali, and Northwest Arctic boroughs. Overall, payments to the state and the boroughs totaled nearly $\$ 15.2$ million, about 9 percent less than in 2001 (table 24).

Table 24. Revenues paid to the State of Alaska and municipalities by Alaska's mineral industry, 1997-2002 ${ }^{a}$

\begin{tabular}{|c|c|c|c|c|c|c|}
\hline & 1997 & 1998 & 1999 & 2000 & 2001 & 2002 \\
\hline \multicolumn{7}{|l|}{ State mineral rents and royalties } \\
\hline State claim rentals ${ }^{\mathrm{b}}$ & $\$ 1,036,782$ & $\$ 1,170,812$ & $\$ 1,982,453$ & $\$ 1,975,376$ & $\$ 1,736,522$ & $1,908,228$ \\
\hline Production royalties & 8,930 & 9,489 & 14,214 & 6,175 & 1,933 & 23,447 \\
\hline Annual labor & 80,795 & 118,020 & 90,720 & 79,907 & 103,274 & 124,741 \\
\hline Subtotal & $1,126,507$ & $1,298,321$ & $2,087,387$ & $2,061,458$ & $1,841,729$ & $2,056,416$ \\
\hline \multicolumn{7}{|l|}{ State coal rents and royalties } \\
\hline Rents & 173,773 & 331,716 & 205,983 & 233,249 & 198,545 & 256,927 \\
\hline Royalties & $1,342,077$ & $1,937,899$ & $2,615,858$ & $1,482,803$ & $1,168,043$ & 860,633 \\
\hline Bonus & 0 & 0 & 0 & 372,000 & 0 & 0 \\
\hline Offshore Prospecting Permits & 0 & 0 & 0 & 0 & 0 & 0 \\
\hline Subtotal & $1,515,850$ & $2,269,615$ & $2,821,841$ & $2,088,052$ & $1,366,588$ & $1,117,560$ \\
\hline \multicolumn{7}{|l|}{ State material sales } \\
\hline Mental Health & 57,620 & 40,269 & 32,407 & 33,928 & 118,545 & 151,993 \\
\hline Division of Land & 278,913 & $1,043,602$ & 586,550 & 449,343 & $1,515,769$ & $1,595,708$ \\
\hline SPCO & 27,579 & 28,491 & 28,941 & 41,395 & 12,894 & 24,725 \\
\hline Subtotal & 364,112 & $1,112,362$ & 647,898 & 524,666 & $1,647,208$ & $1,772,426$ \\
\hline \multicolumn{7}{|l|}{ State mining miscellaneous fees } \\
\hline Filing Fees & 4,187 & 2,510 & 4,288 & 5,400 & 3,000 & 3,000 \\
\hline Penalty Fees & 0 & 0 & 8,000 & 0 & 0 & 450 \\
\hline Explore incentive app filing fee & 0 & 2,000 & 3,000 & 0 & 0 & 0 \\
\hline Bond pool payment & 91,666 & 79,929 & 70,692 & 50,100 & 53,866 & 45,208 \\
\hline Surface coal mining app fee & 16,100 & 6,890 & 2,500 & 1,830 & 3,700 & 2,530 \\
\hline APMA mining fees & 22,454 & 18,975 & 19,288 & 18,550 & 13,175 & 11,975 \\
\hline Subtotal & 134,407 & 110,304 & 107,768 & 75,880 & 73,741 & 63,163 \\
\hline Mining license $\mathrm{e}^{\mathrm{c}}$ & 941,735 & $1,797,292$ & $1,296,663$ & $2,712,541$ & $2,068,232$ & 469,270 \\
\hline State total & $4,082,611$ & $6,587,894$ & 6,961,557 & $7,462,597$ & $6,997,498$ & $5,478,835$ \\
\hline Payments to Municipalities & $8,386,000$ & $7,934,000$ & $8,818,819$ & $9,196,500$ & $9,763,220$ & $9,703,208$ \\
\hline TOTAL & $\$ 12,468,611$ & $\$ 14,521,894$ & $\$ 15,780,376$ & $\$ 16,659,097$ & $\$ 16,760,718$ & $\$ 15,182,043$ \\
\hline
\end{tabular}

${ }^{a}$ Does not include state corporate income taxes, which were not released for this study.

bIncludes upland lease and offshore lease rentals.

'Includes metals, coal, and material. New numbers 1997-2002 from Department of Revenue.

$\mathrm{N} / \mathrm{A}=$ not available.

SourCE: Municipalities, companies, and DNR Financial Services Section. 


\section{APPENDIX A}

\section{New claims staked in Alaska 1998-2002}

\begin{tabular}{|c|c|c|c|c|c|c|c|c|c|c|c|}
\hline \multirow{2}{*}{$\begin{array}{r}\text { Quad } \\
\text { no. }\end{array}$} & \multirow{2}{*}{$\begin{array}{l}\text { Quadrangle } \\
\text { name }^{\mathrm{a}}\end{array}$} & \multicolumn{5}{|c|}{ New federal mining claims } & \multicolumn{5}{|c|}{ New state mining claims } \\
\hline & & 1998 & 1999 & 2000 & 2001 & 2002 & 1998 & 1999 & 2000 & 2001 & 2002 \\
\hline 18 & De Long Mountains & 0 & 0 & 0 & 0 & 0 & 0 & 4,685 & 72 & 79 & 0 \\
\hline 23 & Phillip Smith Mountains & 0 & 0 & 0 & 0 & 0 & 0 & 0 & 0 & 0 & 1 \\
\hline 26 & Noatak & 0 & 0 & 0 & 0 & 0 & 0 & 1,411 & 216 & 112 & 0 \\
\hline 27 & Baird Mountains & 0 & 0 & 0 & 10 & 0 & 0 & 64 & 1 & 0 & 8 \\
\hline 28 & Ambler River & 0 & 0 & 0 & 0 & 0 & 6 & 0 & 95 & 0 & 0 \\
\hline 30 & Wiseman & 90 & 13 & 15 & 12 & 12 & 30 & 92 & 33 & 6 & 14 \\
\hline 31 & Chandalar & 1 & 13 & 10 & 7 & 15 & 56 & 3 & 8 & 14 & 22 \\
\hline 32 & Christian & 0 & 0 & 0 & 0 & 0 & 0 & 0 & 0 & 0 & 1 \\
\hline 36 & Selawik & 0 & 0 & 0 & 0 & 0 & 0 & 2 & 0 & 2 & 0 \\
\hline 37 & Shungnak & 0 & 0 & 0 & 0 & 0 & 0 & 0 & 0 & 14 & 0 \\
\hline 38 & Hughes & 0 & 0 & 0 & 0 & 0 & 1 & 1 & 0 & 1 & 0 \\
\hline 39 & Bettles & 28 & 12 & 1 & 15 & 3 & 1 & 1 & 0 & 0 & 0 \\
\hline 43 & Teller & 0 & 0 & 0 & 0 & 0 & 4 & 24 & 0 & 96 & 60 \\
\hline 44 & Bendeleben & 0 & 0 & 0 & 0 & 0 & 43 & 56 & 64 & 17 & 52 \\
\hline 45 & Candle & 0 & 0 & 0 & 27 & 0 & 8 & 0 & 26 & 51 & 48 \\
\hline 47 & Melozitna & 0 & 0 & 0 & 0 & 0 & 0 & 0 & 1 & 11 & 0 \\
\hline 48 & Tanana & 0 & 0 & 0 & 0 & 0 & 81 & 11 & 134 & 27 & 43 \\
\hline 49 & Livengood & 0 & 0 & 0 & 0 & 0 & 28 & 38 & 186 & 54 & 151 \\
\hline 50 & Circle & 0 & 0 & 0 & 0 & 0 & 663 & 391 & 551 & 111 & 139 \\
\hline 52 & Nome & 0 & 0 & 0 & 0 & 0 & 16 & 1 & 9 & 38 & 13 \\
\hline 53 & Solomon & 0 & 0 & 0 & 0 & 0 & 8 & 11 & 39 & 25 & 11 \\
\hline 55 & Nulato & 0 & 0 & 0 & 0 & 0 & 56 & 80 & 28 & 32 & 0 \\
\hline 56 & Ruby & 0 & 0 & 0 & 0 & 0 & 657 & 90 & 4 & 0 & 0 \\
\hline 57 & Kantishna River & 0 & 0 & 0 & 0 & 0 & 0 & 8 & 0 & 0 & 0 \\
\hline 58 & Fairbanks & 0 & 0 & 0 & 0 & 0 & 73 & 22 & 28 & 55 & 49 \\
\hline 59 & Big Delta & 0 & 0 & 0 & 0 & 0 & 4,290 & 2,775 & 1,547 & 112 & 87 \\
\hline 60 & Eagle & 0 & 0 & 0 & 0 & 0 & 794 & 465 & 761 & 90 & 53 \\
\hline 64 & Ophir & 0 & 0 & 0 & 0 & 0 & 46 & 59 & 12 & 3 & 40 \\
\hline 65 & Medfra & 0 & 0 & 0 & 0 & 0 & 26 & 37 & 0 & 0 & 12 \\
\hline 67 & Healy & 0 & 0 & 0 & 0 & 0 & 683 & 78 & 12 & 73 & 139 \\
\hline 68 & Mt. Hayes & 2 & 0 & 8 & 47 & 36 & 803 & 488 & 517 & 268 & 175 \\
\hline 69 & Tanacross & 0 & 0 & 0 & 0 & 0 & 933 & 313 & 140 & 46 & 0 \\
\hline 73 & Iditarod & 0 & 0 & 0 & 0 & 0 & 94 & 0 & 0 & 8 & 28 \\
\hline 74 & McGrath & 0 & 0 & 0 & 0 & 0 & 0 & 16 & 0 & 23 & 117 \\
\hline 75 & Talkeetna & 0 & 0 & 0 & 0 & 0 & 102 & 83 & 123 & 65 & 77 \\
\hline 76 & Talkeetna Mountains & 0 & 0 & 0 & 0 & 0 & 112 & 18 & 59 & 17 & 37 \\
\hline 77 & Gulkana & 0 & 0 & 0 & 0 & 2 & 6 & 231 & 0 & 0 & 0 \\
\hline 78 & Nabesna & 0 & 0 & 0 & 0 & 0 & 1 & 2 & 0 & 0 & 0 \\
\hline 81 & Russian Mission & 0 & 0 & 0 & 0 & 0 & 0 & 0 & 4 & 0 & 5 \\
\hline 82 & Sleetmute & 0 & 0 & 0 & 0 & 0 & 0 & 62 & 0 & 0 & 6 \\
\hline 83 & Lime Hills & 0 & 0 & 0 & 0 & 0 & 27 & 12 & 0 & 4 & 0 \\
\hline 84 & Tyonek & 0 & 0 & 0 & 0 & 0 & 23 & 86 & 3 & 2 & 0 \\
\hline 85 & Anchorage & 0 & 0 & 0 & 0 & 0 & 84 & 107 & 43 & 35 & 48 \\
\hline 86 & Valdez & 0 & 0 & 0 & 0 & 0 & 0 & 1 & 153 & 0 & 9 \\
\hline 92 & Taylor Mountains & 0 & 0 & 0 & 0 & 0 & 7 & 0 & 12 & 0 & 0 \\
\hline 93 & Lake Clark & 0 & 0 & 0 & 0 & 0 & 0 & 0 & 0 & 8 & 2 \\
\hline 95 & Seward & 44 & 24 & 24 & 16 & 17 & 12 & 29 & 13 & 5 & 10 \\
\hline 96 & Cordova & 0 & 0 & 0 & 0 & 1 & 1 & 0 & 0 & 0 & 0 \\
\hline 97 & Bering Glacier & 0 & 0 & 0 & 0 & 0 & 4 & 0 & 2 & 3 & 0 \\
\hline 102 & Dillingham & 0 & 0 & 63 & 0 & 0 & 0 & 0 & 121 & 84 & 0 \\
\hline 103 & Iliamna & 0 & 0 & 0 & 0 & 0 & 2 & 0 & 2 & 134 & 36 \\
\hline 104 & Seldovia & 0 & 0 & 0 & 0 & 0 & 2 & 0 & 0 & 0 & 0 \\
\hline 109 & Skagway & 0 & 1 & 0 & 0 & 0 & 1 & 38 & 1 & 12 & 1 \\
\hline 112 & Juneau & 52 & 10 & 1 & 0 & 33 & 0 & 0 & 0 & 1 & 6 \\
\hline
\end{tabular}




\begin{tabular}{|c|c|c|c|c|c|c|c|c|c|c|c|}
\hline \multirow{2}{*}{$\begin{array}{r}\text { Quad } \\
\text { no. }\end{array}$} & \multirow{2}{*}{$\begin{array}{c}\text { Quadrangle } \\
\text { name }\end{array}$} & \multicolumn{5}{|c|}{ New federal mining claims } & \multicolumn{5}{|c|}{ New state mining claims } \\
\hline & & 1998 & 1999 & 2000 & 2001 & 2002 & 1998 & 1999 & 2000 & 2001 & 2002 \\
\hline 114 & Sitka & 10 & 0 & 0 & 0 & 0 & 0 & 0 & 0 & 0 & 0 \\
\hline 116 & Port Alexander & 0 & 0 & 2 & 0 & 0 & 0 & 0 & 0 & 0 & 0 \\
\hline 117 & Petersburg & 183 & 98 & 0 & 6 & 141 & 0 & 2 & 0 & 1 & 0 \\
\hline 118 & Bradfield Canal & 0 & 0 & 0 & 0 & 0 & 0 & 0 & 0 & 0 & 2 \\
\hline 119 & Craig & 3 & 137 & 399 & 223 & 0 & 1 & 0 & 0 & 7 & 0 \\
\hline 120 & Ketchikan & 0 & 0 & 0 & 0 & 0 & 0 & 0 & 0 & 0 & 2 \\
\hline 121 & Dixon Entrance & 14 & 0 & 0 & 0 & 5 & 0 & 0 & 0 & 0 & 0 \\
\hline 122 & Prince Rupert & 0 & 0 & 0 & 95 & 4 & 0 & 0 & 0 & 11 & 0 \\
\hline 130 & Karluk & 0 & 0 & 0 & 0 & 0 & 0 & 0 & 0 & 5 & 18 \\
\hline 135 & Trinity Islands & 0 & 0 & 0 & 0 & 0 & 0 & 74 & 66 & 0 & 13 \\
\hline 138 & Port Moller & 0 & 0 & 0 & 0 & 0 & 0 & 10 & 0 & 0 & \\
\hline & TOTALS & 427 & 308 & 523 & 464 & $261 \%$ & 9,785 & 11,977 & 5,086 & 1,763 & 1,531 \\
\hline
\end{tabular}

Source: Data provided by Alaska Department of Natural Resources Land Records Information Section and U.S. Bureau of Land Management.

${ }^{a}$ Unlisted quadrangles did not have any staked mining claims between 1998 and 2002.

*Eight federal claims extend over 2 quadrangles. 


\section{APPENDIX B}

Prospecting sites in Alaska 1996-2002

\begin{tabular}{|c|c|c|c|c|c|c|c|c|c|c|c|}
\hline $\begin{array}{c}\text { Quac } \\
\text { no. }\end{array}$ & Quad name $^{\mathrm{a}}$ & $\begin{array}{l}1996 \\
\text { New }\end{array}$ & $\begin{array}{c}1996 \\
\text { Total }\end{array}$ & $\begin{array}{l}1997 \\
\text { New }\end{array}$ & $\begin{array}{c}1997 \\
\text { Total }\end{array}$ & $\begin{array}{l}1998 \\
\text { New }\end{array}$ & $\begin{array}{c}1998 \\
\text { Total }\end{array}$ & $\begin{array}{l}1999 \\
\text { New }\end{array}$ & $\begin{array}{c}1999 \\
\text { Total }\end{array}$ & $\begin{array}{l}2000 \\
\text { New }\end{array}$ & $\begin{array}{l}2000 \\
\text { Total }\end{array}$ \\
\hline 17 & Point Hope & 0 & 17 & 0 & 15 & 0 & 0 & 0 & 0 & 0 & 0 \\
\hline 18 & De Long Mountains & 0 & 0 & 0 & 0 & 0 & 0 & 27 & 27 & 72 & 99 \\
\hline 26 & Noatak & 24 & 48 & 0 & 48 & 0 & 0 & 0 & 0 & 1 & 1 \\
\hline 27 & Baird Mountains & 8 & 32 & 0 & 32 & 0 & 32 & 0 & 32 & 0 & 32 \\
\hline 30 & Wiseman & 63 & 67 & 2 & 23 & 31 & 38 & 0 & 29 & 11 & 13 \\
\hline 31 & Chandalar & 4 & 30 & 37 & 60 & 14 & 46 & 14 & 24 & 0 & 23 \\
\hline 36 & Selawik & 0 & 5 & 0 & 5 & 1 & 6 & 1 & 7 & 0 & 7 \\
\hline 38 & Hughes & 0 & 0 & 9 & 9 & 0 & 9 & 1 & 10 & 0 & 8 \\
\hline 41 & Fort Yukon & 0 & 0 & 0 & 0 & 0 & 0 & 0 & 0 & 0 & 0 \\
\hline 42 & Black River & 1 & 1 & 0 & 1 & 0 & 0 & 0 & 0 & 0 & 0 \\
\hline 43 & Teller & 0 & 0 & 0 & 0 & 0 & 0 & 0 & 0 & 15 & 15 \\
\hline 44 & Bendeleben & 42 & 60 & 89 & 147 & 4 & 143 & 7 & 136 & 0 & 60 \\
\hline 45 & Candle & 8 & 8 & 13 & 21 & 0 & 20 & 6 & 26 & 32 & 46 \\
\hline 47 & Melozitna & 192 & 192 & 0 & 192 & 0 & 192 & 144 & 336 & 0 & 144 \\
\hline 48 & Tanana & 295 & 401 & 18 & 379 & 5 & 289 & 97 & 337 & 27 & 123 \\
\hline 49 & Livengood & 62 & 301 & 184 & 407 & 111 & 322 & 20 & 147 & 24 & 123 \\
\hline 50 & Circle & 139 & 641 & 176 & 499 & 201 & 528 & 82 & 443 & 32 & 302 \\
\hline 52 & Nome & 66 & 128 & 63 & 173 & 16 & 125 & 21 & 83 & 37 & 102 \\
\hline 53 & Solomon & 34 & 59 & 12 & 64 & 5 & 53 & 10 & 40 & 0 & 28 \\
\hline 55 & Nulato & 4 & 6 & 0 & 6 & 2 & 4 & 22 & 26 & 6 & 32 \\
\hline 56 & Ruby & 16 & 19 & 57 & 76 & 37 & 113 & 8 & 95 & 0 & 48 \\
\hline 57 & Kantishna River & 0 & 0 & 4 & 4 & 0 & 4 & 0 & 4 & 0 & 4 \\
\hline 58 & Fairbanks & 90 & 193 & 63 & 221 & 49 & 149 & 19 & 105 & 0 & 72 \\
\hline 59 & Big Delta & 118 & 244 & 295 & 449 & 1,968 & 2,301 & 967 & 3,152 & 405 & 2,823 \\
\hline 60 & Eagle & 74 & 125 & 52 & 145 & 220 & 336 & 27 & 282 & 76 & 316 \\
\hline 64 & Ophir & 5 & 9 & 46 & 55 & 0 & 53 & 1 & 39 & 177 & 182 \\
\hline 65 & Medfra & 11 & 12 & 22 & 34 & 0 & 21 & 2 & 10 & 0 & 3 \\
\hline 66 & Mt. McKinley & 0 & 0 & 0 & 0 & 0 & 0 & 0 & 0 & 0 & 0 \\
\hline 67 & Healy & 127 & 152 & 397 & 535 & 245 & 748 & 16 & 597 & 13 & 101 \\
\hline 68 & Mt. Hayes & 246 & 273 & 194 & 423 & 73 & 442 & 25 & 414 & 46 & 329 \\
\hline 69 & Tanacross & 56 & 93 & 54 & 110 & 22 & 91 & 155 & 219 & 0 & 185 \\
\hline 73 & Iditarod & 235 & 235 & 0 & 235 & 0 & 207 & 16 & 180 & 0 & 165 \\
\hline 74 & McGrath & 19 & 25 & 198 & 218 & 2 & 204 & 16 & 158 & 52 & 65 \\
\hline 75 & Talkeetna & 15 & 38 & 281 & 308 & 63 & 331 & 19 & 282 & 42 & 77 \\
\hline 76 & Talkeetna Mountains & 0 & 79 & 15 & 40 & 58 & 88 & 2 & 88 & 4 & 75 \\
\hline
\end{tabular}

\begin{tabular}{|r|r|r|r|}
\hline $\mathbf{2 0 0 1}$ & $\mathbf{2 0 0 1}$ & $\mathbf{2 0 0 2}$ & $\mathbf{2 0 0 2}$ \\
\hline New & Total & New & Total \\
\hline 0 & & & \\
\hline 0 & 99 & 0 & 0 \\
\hline 0 & 1 & 0 & 91 \\
\hline 0 & 22 & 0 & 1 \\
\hline 0 & 13 & 0 & 22 \\
\hline 0 & 11 & 0 & 13 \\
\hline 3 & 3 & 0 & 11 \\
\hline 0 & 8 & 0 & 7 \\
\hline 0 & 0 & 0 & 0 \\
\hline 0 & 0 & 0 & 0 \\
\hline 0 & 15 & 0 & 15 \\
\hline 0 & 44 & 0 & 37 \\
\hline 0 & 38 & 0 & 32 \\
\hline 0 & 128 & 0 & 0 \\
\hline 2 & 107 & 0 & 30 \\
\hline 0 & 36 & 7 & 15 \\
\hline 5 & 138 & 9 & 92 \\
\hline 1 & 87 & 0 & 66 \\
\hline 0 & 23 & 0 & 13 \\
\hline 0 & 30 & 0 & 16 \\
\hline 0 & 11 & 0 & 3 \\
\hline 0 & 4 & 0 & 4 \\
\hline 2 & 32 & 0 & 19 \\
\hline 1 & 913 & 0 & 555 \\
0 & 142 & 0 & 108 \\
\hline 0 & 182 & 0 & 181 \\
\hline 0 & 1 & 0 & 1 \\
0 & 0 & 0 & 0 \\
\hline 0 & 48 & 0 & 34 \\
\hline 8 & 277 & 0 & 264 \\
0 & 147 & 0 & 0 \\
\hline 4 & 169 & 3 & 152 \\
0 & 65 & 0 & 57 \\
0 & 68 & 27 & 64 \\
0 & 44 & 4 & 46 \\
\hline & & & \\
\hline
\end{tabular}


APPENDIX B

Prospecting sites in Alaska 1996-2002

\begin{tabular}{|c|c|c|c|c|c|c|c|c|c|c|c|}
\hline $\begin{array}{c}\text { Quad } \\
\text { no. }\end{array}$ & Quad name & $\begin{array}{l}1996 \\
\text { New }\end{array}$ & $\begin{array}{l}1996 \\
\text { Total }\end{array}$ & $\begin{array}{l}1997 \\
\text { New }\end{array}$ & $\begin{array}{l}1997 \\
\text { Total }\end{array}$ & $\begin{array}{l}1998 \\
\text { New }\end{array}$ & $\begin{array}{l}1998 \\
\text { Total }\end{array}$ & $\begin{array}{l}1999 \\
\text { New }\end{array}$ & $\begin{array}{c}1999 \\
\text { Total }\end{array}$ & $\begin{array}{l}2000 \\
\text { New }\end{array}$ & $\begin{array}{c}2000 \\
\text { Total }\end{array}$ \\
\hline 77 & Gulkana & 0 & 0 & 8 & 8 & 0 & 8 & 0 & 8 & 3 & 3 \\
\hline 781 & Nabesna & 0 & 0 & 0 & 0 & 0 & 0 & 0 & 0 & 4 & 4 \\
\hline $81 \mathrm{I}$ & Russian Mission & 0 & 0 & 46 & 46 & 0 & 46 & 0 & 46 & 0 & 46 \\
\hline 82 & Sleetmute & 0 & 0 & 46 & 46 & 0 & 46 & 0 & 46 & 0 & 26 \\
\hline $83 \mathrm{I}$ & Lime Hills & 0 & 0 & 9 & 9 & 0 & 9 & 0 & 0 & 0 & 0 \\
\hline 847 & Tyonek & 14 & 28 & 6 & 20 & 0 & 20 & 0 & 14 & 0 & 0 \\
\hline 85 & Anchorage & 21 & 84 & 24 & 98 & 5 & 64 & 10 & 64 & 3 & 62 \\
\hline 86 & Valdez & 9 & 38 & 0 & 27 & 0 & 16 & 0 & 16 & 25 & 41 \\
\hline $91 \mathrm{I}$ & Bethel & 16 & 22 & 4 & 26 & 0 & 12 & 18 & 22 & 0 & 18 \\
\hline 927 & Taylor Mountains & 6 & 6 & 0 & 6 & 32 & 38 & 0 & 32 & 0 & 0 \\
\hline 95 & Seward & 26 & 26 & 2 & 26 & 1 & 20 & 2 & 5 & 0 & 2 \\
\hline $97 \mathrm{I}$ & Bering Glacier & 0 & 0 & 0 & 0 & 2 & 2 & 0 & 2 & 0 & 2 \\
\hline $102 \mathrm{I}$ & Dillingham & 0 & 0 & 48 & 48 & 0 & 48 & 0 & 44 & 0 & 0 \\
\hline $103 \mathrm{I}$ & Iliamna & 0 & 0 & 0 & 0 & 0 & 0 & 0 & 0 & 0 & 0 \\
\hline 104 & Seldovia & 1 & 1 & 0 & 0 & 0 & 0 & 0 & 0 & 0 & 0 \\
\hline $105 \mathrm{I}$ & Blying Sound & 7 & 7 & 0 & 7 & 0 & 7 & 0 & 0 & 0 & 0 \\
\hline 109 & Skagway & 0 & 0 & 6 & 6 & 4 & 10 & 0 & 4 & 0 & 0 \\
\hline $117 \mathrm{~J}$ & Juneau & 13 & 13 & 0 & 13 & 0 & 5 & 0 & 5 & 0 & 5 \\
\hline 123 & Sitka & 0 & 0 & 0 & 0 & 0 & 0 & 0 & 0 & 0 & 0 \\
\hline 128 & Try Islands & 14 & 16 & 0 & 14 & 17 & 31 & 0 & 17 & 14 & 28 \\
\hline $137 \mathrm{I}$ & Ketchikan & 1 & 1 & 0 & 0 & 0 & 0 & 0 & 0 & 0 & 0 \\
\hline TOTA & ALS & 2,082 & 3,735 & 2,480 & 5,334 & 3,188 & 7,277 & 1,755 & 7,653 & 1,121 & 5,840 \\
\hline
\end{tabular}

${ }^{a}$ Unlisted quadrangles did not have any prospect sites staked during 1996-2002.

SOURCE: Data provided by Alaska Department of Natural Resources Land Records Information Section. 


\section{APPENDIX C}

\section{Selected significant mineral deposits and mineral districts in Alaska ${ }^{\mathrm{a}}$}

The alphabetized list of mineral deposits and mineral districts is keyed to the list of explanatory paragraphs that follow. For example, The Lik deposit in the alphabetized list is "Lik, 1, (fig. C-1)." This says that the location of Lik is shown as number 1 in figure $\mathrm{C}-1$.

Alaska-Juneau, 100, (fig. C-3).

Anderson Mountain, 54, (fig. C-1).

Aniak district, 84, (fig C-3).

Apex-EI Nido, 104, (fig. C-3).

Apollo-Sitka mines, 86, (fig. C-3).

Arctic, 9, (fig. C-1).

Avan Hills, 12, (fig. C-3).

Baultoff, 75, (fig. C-2).

Bear Mountain, 21, (fig. C-2).

Big Creek/Ladue, 58, (fig. C-1).

Big Hurrah, 32, (fig. C-3).

Binocular and other prospects, 72 , (fig. C-1).

Bohemia Basin, 103, (fig. C-3).

Bokan Mountain, 122, (fig. C-3).

Bonanza Creek, 45, (fig. C-2).

Bond Creek, 73, (fig. C-2).

Bonnifield district massive sulfide deposits, 54, (fig. C-1).

Bornite, 8 , (fig. C-1).

Brady Glacier, 98, (fig. C-3).

BT, 54, (fig. C-1).

Buck Creek, 23, (fig. C-2).

Calder Mine, 133, (fig C-2).

Canwell and Nikolai Complex, 140 (fig.

C-3)

Cape Creek, 22, (fig. C-2).

Carl Creek, 74, (fig. C-2).

Casca VABM, 53, (fig. C-1).

Castle Island, 111, (fig. C-1).

Chandalar mining district, 17, (fig. C-3).

Chichagof, 101, (fig. C-3).

Chistochina, 68, (figs. C-2, C-3).

Circle mining district, 52, (fig. C-3).

Claim Point, 82, (fig. C-3).

Coal Creek, 63, (fig. C-2).

Copper City, 119, (fig. C-1).

Cornwallis Peninsula, 110, (fig. C-1).

Council mining district, 33, (fig. C-3).

Delta massive sulfide belt, 55, (fig. C-1).

Denali prospect, 67, (fig. C-1).

Dolphin, 49e, (fig. C-3).

Donlin Creek, 137, (fig. C-3).

Drenchwater, 3, (fig. C-1).

Dry Creek, 54, (fig. C-1).

Duke Island, 141 (fig. C-3)

Eagle Creek, 34, (fig. C-3).

Ear Mountain, 25, (fig. C-2).

Ellamar, 78, (fig. C-1).

Ernie Lake (Ann Creek), 15, (fig. C-1).

Esotuk Glacier, 20, (fig. C-2).

Fairbanks mining district, 49, (fig. C-3).

Fairhaven/Inmachuk district, 39, (fig. C-3).

Fort Knox, 49a, (fig. C-3).

Fortymile mining district, 60, (fig. C-3).

Frost, 7a, (fig. C-1).

Funter Bay mining district, 99, (fig. C-3).

Galena Creek, 21a, (fig. C-1).

Gil Claims, 49f, (fig. C-3).
Ginny Creek, 4, (fig. C-1).

Golden Zone mine, 64, (figs. C-1, C-3).

Goodnews Bay, 85, (fig. C-3).

Grant Mine, 49c, (fig. C-3).

Greens Creek, 105, (fig. C-1).

Groundhog Basin, 112, (fig. C-1)

Haines Barite/Palmer, 95, (fig. C-1).

Hannum, 27, (fig. C-1).

Hirst Chichagof, 101, (fig. C-3).

Horsfeld, 76, (fig. C-2).

Hot Springs mining district, 47 , (figs. C-2, C-3).

Hyder mining district, 117, (figs. C-1, C-2).

Iditarod district, 43, (fig. C-3).

Illinois Creek, 132, (figs. C-1, C-3).

Independence, 79, (fig. C-3).

Independence Creek, 28, (fig. C-1).

Inmachuk River, 39, (fig. C-3).

Innoko-Tolstoi mining district, 44 , (fig. C-3).

Ivanof, 88 , (fig. C-2).

Jimmy Lake, 94, (fig. C-1).

Johnson River, 125, (fig. C-3).

Jualin, 128, (fig. C-3).

Jumbo, 118, (fig. C-1).

Kaiyah, 138, (fig. C-3).

Kantishna mining district, 61, (fig. C-3).

Kasaan Peninsula, 114, (fig. C-1).

Kasna Creek, 92, (fig. C-1).

Kemuk Mountain, 123, (fig. C-3).

Kennecott deposits, 71, (fig. C-1).

Kensington, 127, (fig. C-3).

Kivliktort Mountain, 5a, (fig. C-1).

Klery Creek, 14, (fig. C-3).

Klukwan, 96, (fig. C-3).

Kougarok Mountain, 26, (fig. C-2).

Koyukuk-Hughes mining district, 42, (fig. C-3).

Koyukuk-Nolan mining district, 16 , (fig. C-3).

Latouche, Beatson, 80, (fig. C-1).

Liberty Belle, 54, (fig. C-1).

Lik, 1, (fig. C-1).

Livengood-Tolovana mining district, 48 , (fig. C-3).

Lost River, 24, (fig. C-2).

Lucky Shot, 79, (fig. C-3).

McLeod, 124, (fig. C-2).

Mertie Lode, 99, (fig. C-3).

Midas mine, 77, (fig. C-1).

Mike deposit, 90, (fig. C-2).

Mirror Harbor, 102, (fig. C-3).

Misheguk Mountain, 13, (fig. C-3).

Mosquito, Peternie, 56, (fig. C-2).

Mt. Prindle, 50, (fig. C-3).

Nabesna mine, 69, (fig. C-3).

Niblack, 121, (fig. C-1).

Nim prospect, 65, (fig. C-1).
Nimiuktuk River, 126, (fig. C-1).

Nixon Fork, 135, (fig. C-3).

Nome mining district, 30, (fig. C-3).

Nunatak, 97, (fig. C-2).

Omalik, 35, (fig. C-1).

Omar, 7, (fig. C-1).

Orange Hill, 73, (fig. C-2).

Pebble Copper, 129, (fig. C-1).

Placer River, 38, (fig. C-2).

Pleasant Creek, 53, (fig. C-1).

Pogo, 130, (fig. C-3).

Poovookpuk Mountain, 40, (fig. C-2).

Porcupine Lake, 18, (fig. C-2).

Purcell Mountain, 41, (fig. C-2).

Pyramid, 87, (fig. C-2).

Quartz Creek, 37, (fig. C-1).

Quartz Hill, 120, (fig. C-2).

Red Bluff Bay, 109, (fig. C-3).

Red Devil, 83, (fig. C-3).

Red Dog, 2, (fig. C-1).

Red Mountain, 82, (fig. C-3).

Rex deposit, 91, (fig. C-2).

Rock Creek, 31, (fig. C-3).

Rua Cove, 81, (fig. C-1).

Ruby mining district, 46, (fig. C-3).

Ryan Lode, 49b, (fig. C-3).

Salt Chuck, 115, (fig. C-3).

Sheep Creek, 54, (fig. C-1).

Shotgun Hills, 131, (fig. C-3).

Shulin Lake, 139 (fig. C-3)

Sinuk River region, 29, (fig. C-1).

Slate Creek, 59, (fig. C-3).

Sleitat Mountain, 93, (fig. C-2).

Smucker, 11, (fig. C-1).

Snettisham, 107, (fig. C-3)

Snipe Bay, 113, (fig. C-3).

Solomon mining district, 33, (fig. C-3).

Spirit Mountain, 70, (fig. C-3).

Stampede mine, 62, (fig. C-3).

Story Creek, 5, (fig. C-1).

Sumdum, 106, (fig. C-1).

Sun, 10, (fig. C-1).

Taurus, 57, (fig. C-2).

Three Castle Mountain, 53, (fig. C-1).

Tracy Arm, 108, (fig. C-1).

True North, 49d, (fig. C-3).

Twin Mountain, 51, (fig. C-2).

Union Bay, 116, (fig. C-3).

Valdez Creek district, 66, (fig. C-3).

Vinasale Mountain, 134, (fig. C-3).

Virginia Creek, 54, (fig. C-1).

Von Frank Mountain, 136, (fig. C-3).

War Baby, 79, (fig. C-3).

Weasel Mountain, Bee Creek, 89, (fig. C-2).

Whoopee Creek, 6, (fig. C-1).

Willow Creek, 79, (fig. C-3).

Wind River, 19, (fig. C-1).

Windy Creek, 36, (fig. C-2).

Zackly, 67a, (fig. C-1).

\footnotetext{
${ }^{\mathrm{a}}$ This generalized summary does not describe all of the known 6,400 mineral deposits in Alaska. NOTE: In cooperation with DGGS and the Russian Academy of Sciences, the USGS published Open-File Report 93-339 (Nokleberg and others, 1993), Metallogenesis of mainland Alaska and the Russian northeast, which describes 273 lode deposits and 43 significant placer districts in Alaska.
} 


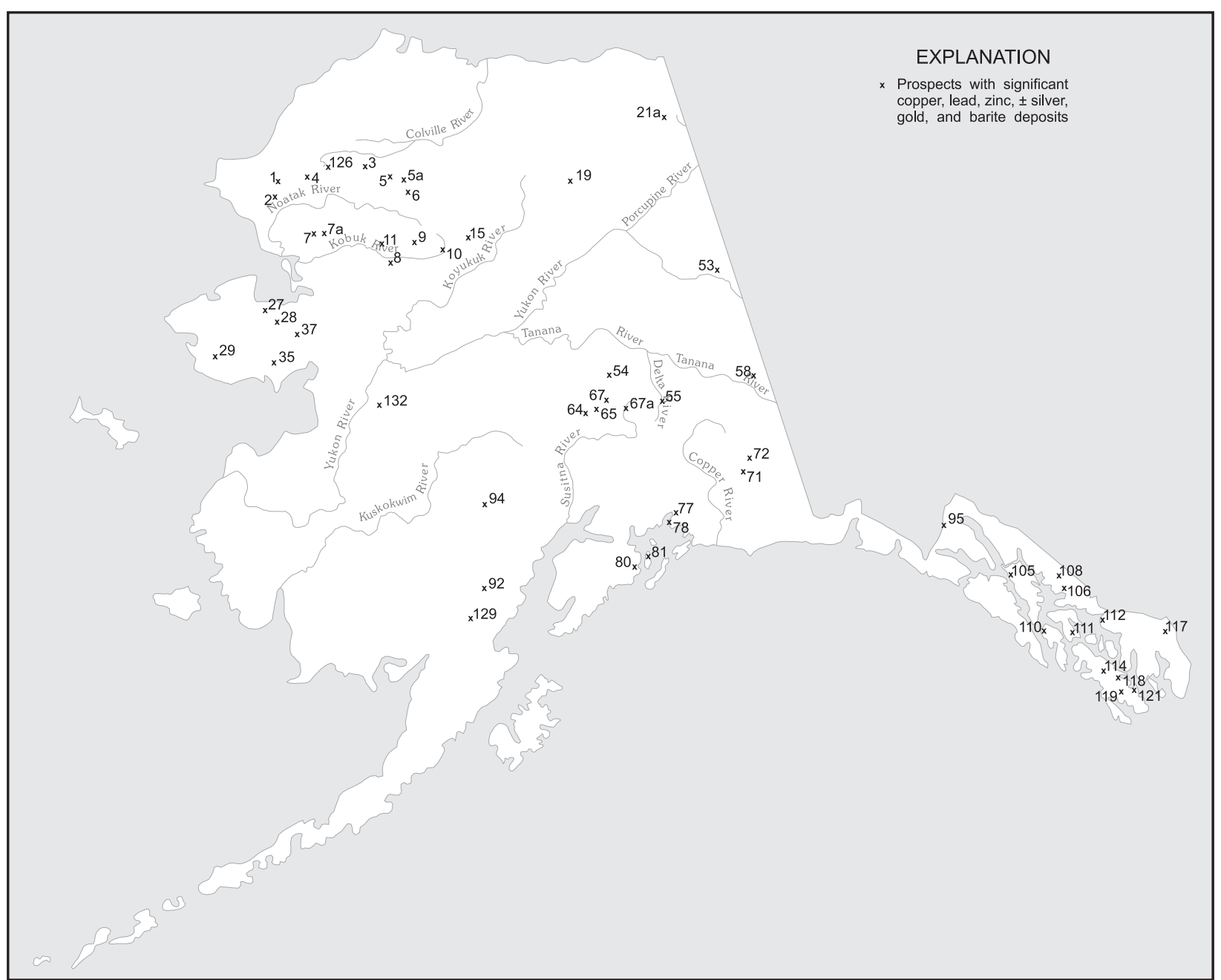

Figure C-1. Significant copper, lead, zinc with credits of silver, gold, and barite deposits in Alaska, 2002.

Map no.

1 Lik-Major stratabound massive-sulfide $(\mathrm{Zn}-\mathrm{Pb}-\mathrm{Ag}-$ $\mathrm{Ba})$ deposit in black shale and chert. Proven reserve (Lik) estimate of 24 million tons of $9 \% \mathrm{Zn}, 3.1 \% \mathrm{~Pb}$, and $1.4 \mathrm{oz} /$ ton $\mathrm{Ag}$ (fig. C-1).

2 Red Dog-At least five major stratabound massivesulfide deposits hosted in Pennsylvanian or Mississippian shale; similar to locality 1 . Mining from 1989 to 2002 produced 5.2 million tons of $\mathrm{Zn}, 832,796$ tons of $\mathrm{Pb}$, and 51.5 million oz Ag. Deposits include: (a) the Main deposit at Red Dog, which contains 46.2 million tons of proven ore grading $19.2 \% \mathrm{Zn}, 5.2 \% \mathrm{~Pb}$, with $2.92 \mathrm{oz} /$ ton Ag; (b) the Aqqaluk deposit, which contains probable, indicated, and inferred reserves of 73.0 million tons grading $15.2 \% \mathrm{Zn}, 4.03 \% \mathrm{~Pb}$, and $2.17 \mathrm{oz} /$ ton Ag; (c) the Qanaiyaq (formerly named Hilltop) deposit, with an indicated reserve of 10.6 million tons grading $17.8 \% \mathrm{Zn}, 5.5 \% \mathrm{~Pb}$, and $3.41 \mathrm{oz} /$ ton $\mathrm{Ag}$; (d) inferred resource in the Paalaaq deposit of 14.3 million tons of $15.0 \% \mathrm{Zn}, 4.0 \% \mathrm{~Pb}$, and $2.63 \mathrm{oz} /$ ton $\mathrm{Ag}$; and (e) Anarraq deposit, discovered in 1999, with an inferred reserve of 19.0 million tons of $15.8 \% \mathrm{Zn}, 4.8 \% \mathrm{~Pb}$, and $2.07 \mathrm{oz} /$ ton $\mathrm{Ag}$ (fig. C-1).

3 Drenchwater-Mississippian and Pennsylvanian shales and cherts contain three stratabound base metal occurrences spatially related to acid volcanics. The lowest unit, a siliceous mudstone, contains a $2 \mathrm{ft}$ layer with up to $23 \% \mathrm{Zn}$. An overlying gray chert contains up to $11 \% \mathrm{Zn}$ and up to $5 \% \mathrm{~Pb}$ with some $\mathrm{Ag}$ in fracture fillings. At the top of the overlying tuffaceous layer, Agbearing $\mathrm{Zn}$ and $\mathrm{Pb}$ mineralization outcrops discontinuously for at least $6,500 \mathrm{ft}$, and contains up to $26 \% \mathrm{Zn}$ and $51 \% \mathrm{~Pb}$ in grab samples (fig. C-1).

4 Ginny Creek-Epigenetic, disseminated $\mathrm{Zn}-\mathrm{Pb}-\mathrm{Ag}$ deposits with barite in sandstone and shale of Noatak Sandstone of Late Devonian through Early Mississippian age. Random grab samples of surface float contain $0.3 \%$ to $3.0 \% \mathrm{Zn}$ and highly variable amounts of $\mathrm{Pb}$ and $\mathrm{Ag}$ (fig. C-1).

5 Story Creek-Epigenetic replacement deposits of Zn$\mathrm{Pb}-\mathrm{Ag}-\mathrm{Cu}-\mathrm{Au}$ hosted in brecciated zones in Devonian Kanayut Conglomerate or Lower Mississippian Kayak 


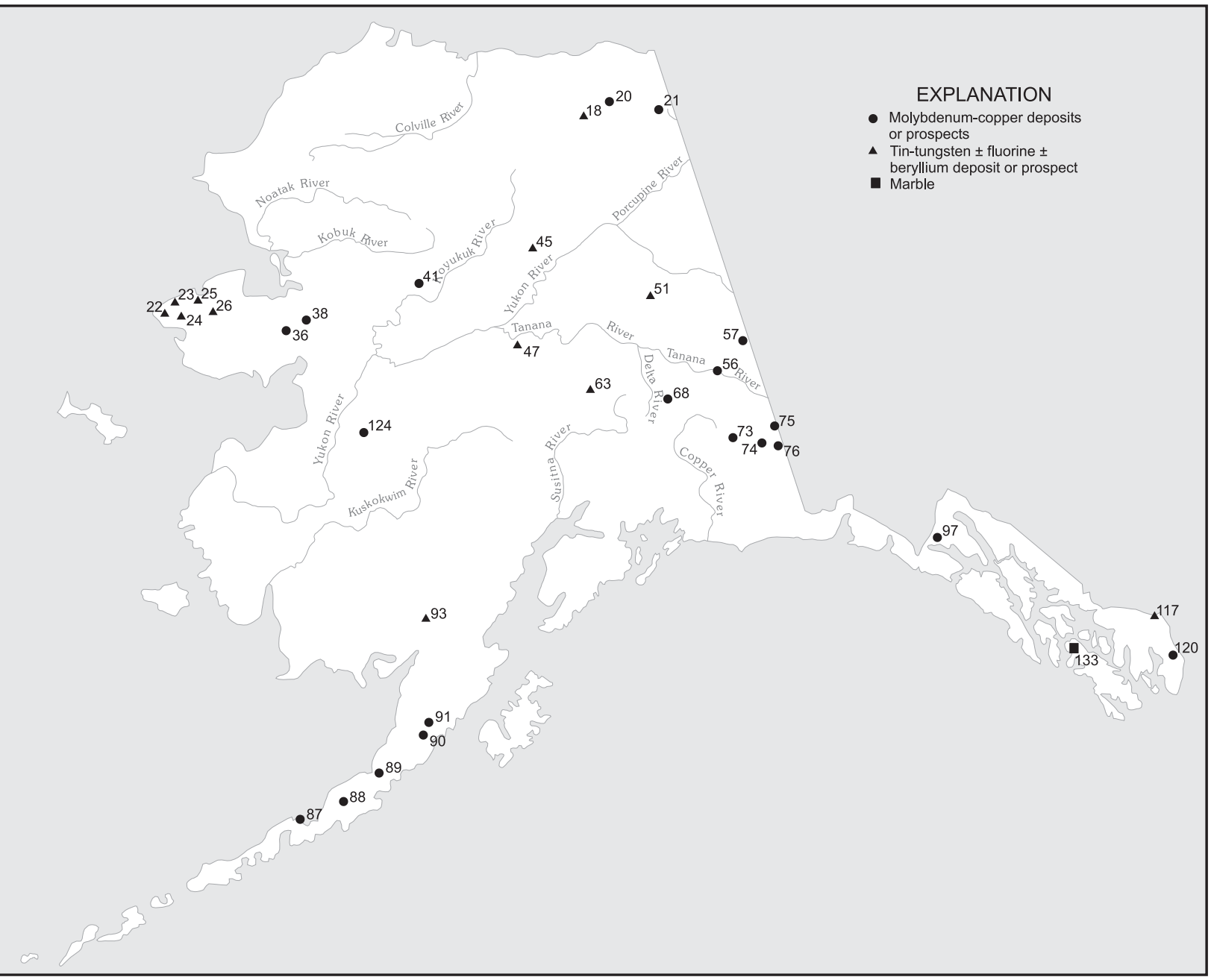

Figure C-2. Significant molybdenum-copper and tin-tungsten with credits of fluorite and beryllium deposits in Alaska, 2002.

Shale. Grab samples of high-grade material contain up to $0.43 \% \mathrm{Cu}, 34 \% \mathrm{~Pb}, 28.8 \% \mathrm{Zn}, 0.04 \mathrm{oz} /$ ton $\mathrm{Au}$, and $30 \mathrm{oz} /$ ton Ag (fig. C-1).

5a Kivliktort Mountain-Mineralized float is widespread on the north flanks of the mountain, apparently spatially related to the contact between shales at the base of the hills and coarse-grained siliceous clastic rocks on the upper slopes. Rock samples containing up to $30 \% \mathrm{Zn}$ have been reported (fig. C-1).

6 Whoopee Creek-Epigenetic replacement deposits of $\mathrm{Zn}-\mathrm{Pb}-\mathrm{Cu}-\mathrm{Ag}-\mathrm{Au}-\mathrm{Cd}$ in breccia zones in Devonian Kanayut Conglomerate or Lower Mississippian Kayak Shale. Random grab samples of mineralized material contain $0.24 \% \mathrm{Cu}, 0.37 \% \mathrm{Cd}, 46 \% \mathrm{Zn}, 44 \% \mathrm{~Pb}, 0.14$ oz/ton Au, and $14.8 \mathrm{oz} /$ ton $\mathrm{Ag}$ (fig. C-1).

7 Omar-Epigenetic replacement deposits of Paleozoic age; include bedded barite occurrences. Grab samples contain $15.3 \% \mathrm{Cu}, 0.15 \% \mathrm{~Pb}, 0.95 \% \mathrm{Zn}, 0.05 \% \mathrm{Co}$, and $0.3 \mathrm{oz} /$ ton $\mathrm{Ag}$. BLM estimates 35 million tons of $4 \% \mathrm{Cu}$ (fig. $\mathrm{C}-1$ ). 7a Frost-Possible 9 million tons of barite in pods, lenses, and wavy-banded quartz-calcite-barite veins. Chalcopyrite and galena occur in the veins which cross cut Paleozoic limestone and dolomite for a minimum distance of $1 \mathrm{mi}$. Selected samples contain up to $13.2 \%$ Zn (fig. C-1).

8 Bornite-Major stratabound $\mathrm{Cu}-\mathrm{Zn}$ deposit in brecciated carbonate rock of Devonian age; 5.0 million ton orebody contains $4.0 \% \mathrm{Cu}$ and accessory $\mathrm{Zn}$ and Co. Larger reserve estimate of 40 million tons of about $2 \% \mathrm{Cu}$ and undisclosed amount of $\mathrm{Zn}$ and $\mathrm{Co}$. At grade of $1.2 \% \mathrm{Cu}$, reserves are 100 million tons (fig. $\mathrm{C}-1$ ).

9 Arctic-Major volcanogenic $(\mathrm{Cu}-\mathrm{Zn})$ massive-sulfide deposit hosted in sequence of metarhyolite, metatuff, and graphitic schist of Devonian age; indicated reserves of 40 million tons grade $4.0 \% \mathrm{Cu}, 5.5 \% \mathrm{Zn}, 0.8 \% \mathrm{~Pb}$, $1.6 \mathrm{oz} / \mathrm{ton} \mathrm{Ag}$, and $0.02 \mathrm{oz} /$ ton $\mathrm{Au}$ (fig. C-1).

$10 \mathrm{Sun}-$ Major $(\mathrm{Cu}-\mathrm{Pb}-\mathrm{Zn}-\mathrm{Ag})$ massive-sulfide deposit in sequence of middle Paleozoic metarhyolite and metabasalt. Average grades are 1 to $4 \% \mathrm{~Pb}, 6$ to $12 \%$ $\mathrm{Zn}, 0.5$ to $7 \% \mathrm{Cu}, 3$ to $11 \mathrm{oz} / \mathrm{ton} \mathrm{Ag}$ (fig. C-1). 


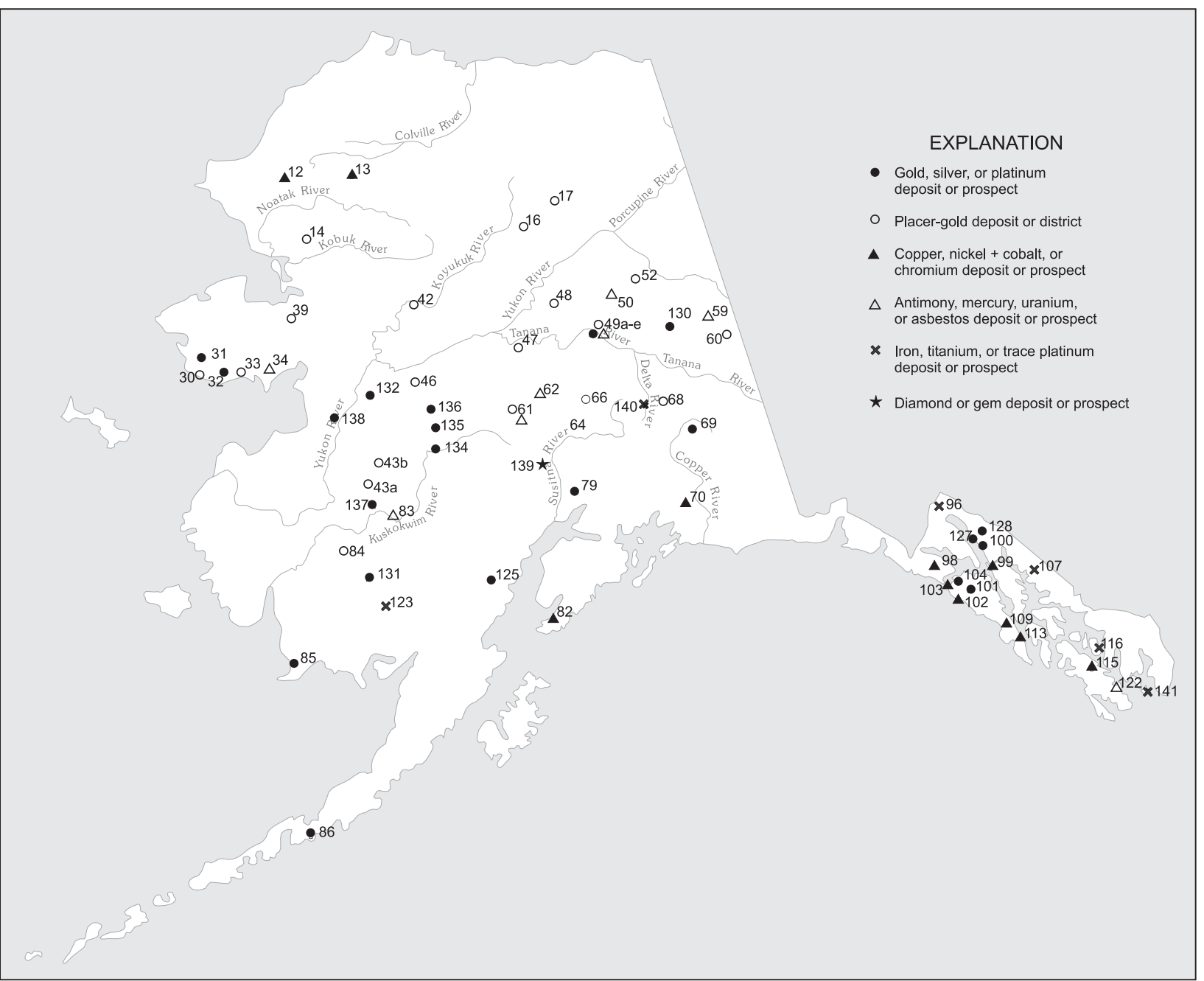

Figure C-3. Significant gold, silver, platinum, and strategic mineral deposits in Alaska, 2002.

11 Smucker-Middle Paleozoic volcanogenic massivesulfide deposit; 3,000 ft long and up to $190 \mathrm{ft}$ wide; contains significant tonnage of $\mathrm{Cu}-\mathrm{Pb}-\mathrm{Zn}$ ore that grades $1.5 \% \mathrm{~Pb}, 5$ to $10 \% \mathrm{Zn}, 3$ to $10 \mathrm{oz} /$ ton $\mathrm{Ag}$, with minor $\mathrm{Au}$ (fig. $\mathrm{C}-1$ ).

12 Avan Hills - Disseminated chromite in layered ultramafic rocks; grab samples contain up to $4.3 \% \mathrm{Cr}$ with $0.015 \mathrm{oz} /$ ton PGM (fig. C-3).

13 Misheguk Mountain-Chromite occurrences similar to those in Avan Hills (fig. C-3).

14 Klery Creek-Lode and placer Au deposits worked intermittently from 1909 through 1930s. Total production through 1931, mostly from placer deposits, estimated at 31,320 oz Au (fig. C-3).

15 Ernie Lake (Ann Creek) - Stratabound massive-sulfide occurrence in metarhyolite, metatuff, and marble. Gossan zones strongly anomalous in $\mathrm{Cu}-\mathrm{Pb}-\mathrm{Zn}$ and $\mathrm{Ag}$ (fig. C-1).

16 Koyukuk-Nolan mining district-Major placer $\mathrm{Au}$ district; from 1893 to 2002 produced an estimated 344,983 oz Au. Gold placers in Nolan Creek mined on surface and underground, both sources of large gold nuggets. Significant deep placer reserves remain (fig. C-3).

17 Chandalar mining district-Major $\mathrm{Au}$-producing district; substantial production in excess of $65,860 \mathrm{oz}$ Au through 2002 from lode and placer sources; lode $\mathrm{Au}$ found in crosscutting quartz veins that intrude schist and greenstone. Active development of placer deposits and lodes in progress. Inferred lode reserves estimated to be 45,000 tons with grade of $2 \mathrm{oz} /$ ton $\mathrm{Au}$ (fig. C-3).

18 Porcupine Lake - Stratiform fluorite occurrences and argentiferous enargite, tetrahedrite associated with felsic volcanic rocks of late Paleozoic age. Reported grades of up to $30 \%$ fluorite $\left(\mathrm{CaF}_{2}\right)$ reported, with grab samples of $4.8 \% \mathrm{Cu}$ (fig. $\mathrm{C}-2$ ).

19 Wind River - Stratabound $\mathrm{Pb}-\mathrm{Zn}$ massive-sulfide prospects; reported grades of up to $5 \% \mathrm{~Pb}$ (fig. $\mathrm{C}-1$ ).

20 Esotuk Glacier-Disseminated $\mathrm{Mo}-\mathrm{Sn}-\mathrm{W}-\mathrm{Pb}-\mathrm{Zn}$ mineralization in skarns associated with Devonian(?) schistose quartz monzonite. Grab samples contain up to $0.08 \% \mathrm{Sn}$ and $0.15 \% \mathrm{~W}$ (fig. C-2). 
21 Bear Mountain-Major stockwork Mo-W-Sn occurrence in intrusive breccia. Rock samples containing up to $0.8 \%$ Mo and $0.6 \% \mathrm{~W}$ occur within a 35 -acre area where soil samples average more than $0.2 \% \mathrm{MoS}_{2}$, and an adjacent 25 -acre area where rubble contains wolframite has soils averaging greater than $0.12 \% \mathrm{WO}_{3}$. Rubble crop in this area indicates a Tertiary porphyry system as the source of the Mo and W (fig. C-2).

21a Galena Creek - Steeply dipping veins contain up to $21 \% \mathrm{Cu}, 3.5 \% \mathrm{Zn}$, and $1.3 \% \mathrm{~Pb}$ with $5.5 \mathrm{oz} /$ ton $\mathrm{Ag}$ on the east side of the creek, and on the ridge west of the creek a large area of disseminated mineralization and veinlets contains predominantly $\mathrm{Zn}$ (fig. C-1).

22 Cape Creek-Major placer Sn producer. More than 500 tons Sn produced from 1935 to 1941; from 1979 to 1990, produced 1,040 tons Sn. Derived from Cape Mountain in contact zone of Cretaceous granite and limestone (fig. C-2).

23 Buck Creek-Major placer Sn producer. More than 1,100 tons Sn produced from 1902 to 1953 (fig. C-2).

24 Lost River-Major Sn, fluorite, W, and Be deposit associated with Cretaceous $\mathrm{Sn}$ granite system. More than 350 tons $\mathrm{Sn}$ produced from skarn and greisen lode sources. Measured reserves amount to 24.6 million tons that grade $0.15 \% \mathrm{Sn}, 16.3 \% \mathrm{CaF}_{2}$, and $0.03 \% \mathrm{WO}_{3}$, based on 45,000 ft of diamond drilling (fig. C-2).

25 Ear Mountain - Placer Sn district and $\mathrm{Sn}-\mathrm{Cu}-\mathrm{Au}-\mathrm{Ag}-$ $\mathrm{Pb}-\mathrm{Zn}$ skarn mineralization of Cretaceous age. Area also anomalous in $\mathrm{U}$ (fig. C-2).

26 Kougarok Mountain - Sn deposit hosted in quartztourmaline-topaz greisen of Cretaceous age. Grades may average $0.5 \% \mathrm{Sn}$ and $0.01 \% \mathrm{Ta}$ and $\mathrm{Nb}$, but a highgrade resource of 150,000 tons grading $1 \%+$ Sn has been identified, with incrementally higher tonnage at lower grades (fig. C-2).

27 Hannum - Stratiform, carbonate-hosted $\mathrm{Pb}-\mathrm{Zn}-\mathrm{Ag}$ massive-sulfide deposit of mid-Paleozoic age in heavily oxidized zone that ranges from 30 to $150 \mathrm{ft}$ thick. Mineralized zone reported to assay up to $10 \% \mathrm{~Pb}, 2.2 \%$ $\mathrm{Zn}, 0.04 \mathrm{oz} /$ ton $\mathrm{Au}$, and $1.76 \mathrm{oz} /$ ton $\mathrm{Ag}$ (fig. C-1).

28 Independence $\mathbf{C r e e k}-\mathrm{Pb}-\mathrm{Zn}$ - $\mathrm{Ag}$ massive-sulfide deposit; high-grade ore shipped in 1921 contained 30\% $\mathrm{Pb}, 5 \% \mathrm{Zn}$, up to $150 \mathrm{oz} /$ ton $\mathrm{Ag}$. Mineralization restricted to shear zone in carbonates (fig. C-1).

29 Sinuk River region - Several $\mathrm{Pb}-\mathrm{Zn}-\mathrm{Ag}-\mathrm{Ba}-\mathrm{F}$ bearing massive-sulfide deposits and layered $\mathrm{Fe}$ deposits in carbonate and metavolcanic rocks of Nome Group. Mineralized zones extend for over 8,000 ft along strike (fig. C-1).

30 Nome mining district-Major placer Au producer. Production from 1897-2002 in excess of 4,988,928 oz $\mathrm{Au}$ all from placers. Past sporadic $\mathrm{Sb}$ and $\mathrm{W}$ production (fig. C-3).

31 Rock Creek-858,000 oz Au resource, with about 10.25 million tons grading $0.078 \mathrm{oz} /$ ton $\mathrm{Au}$ in vein swarms and stringers in an area 1,500 ft long, $500 \mathrm{ft}$ maximum width and $300 \mathrm{ft}$ deep (fig. C-3).
32 Big Hurrah-Epigenetic vein deposit in black slate and metasedimentary rocks of the Nome Group. Deposit contains some $\mathrm{W}$ mineralization and has produced over 27,000 oz Au from nearly 50,000 tons milled ore. Proven, inferred, and indicated reserves total 104,000 tons that grade $0.61 \mathrm{oz} /$ ton $\mathrm{Au}, 0.55 \mathrm{oz} /$ ton $\mathrm{Ag}$, and credits of $\mathrm{WO}_{3}$ (fig. C-3).

33 Solomon and Council mining districts-Major placer Au districts; produced over 1,046,513 oz through 2002. Three structurally controlled Au deposits in Bluff area-Daniels Creek, Saddle, and Koyana Creekcontain minimum inferred reserves of 6.5 million tons grading $0.1 \mathrm{oz} /$ ton $\mathrm{Au}$ (fig. C-3).

34 Eagle Creek - U prospect in Cretaceous Kachauik alkalic intrusive rocks. Highly anomalous geochemical values and $U$ concentrations of $1,000 \mathrm{ppm}$ reported (fig. C-3).

35 Omalik-Vein-type $\mathrm{Pb}-\mathrm{Zn}$ - Ag massive-sulfide prospect in Paleozoic carbonate rocks; from 1881 to 1900 , produced 400 tons of $\mathrm{Pb}-\mathrm{Zn}$ ore that averaged about $10 \% \mathrm{~Pb}$ and $40 \mathrm{oz} /$ ton $\mathrm{Ag}$. Grades of oxidized $\mathrm{Zn}$ ore reported to be up to $34 \% \mathrm{Zn}$ (fig. C-1).

36 Windy Creek-Disseminated $\mathrm{Mo}-\mathrm{Pb}-\mathrm{Zn}$ mineralization in quartz veins and skarns with reported values as high as $0.15 \%$ Mo (fig. C-2).

37 Quartz Creek-Significant $\mathrm{Pb}-\mathrm{Zn}-\mathrm{Ag}$ mineralization; reported grades of $15 \%$ combined $\mathrm{Pb}-\mathrm{Zn}$ and $10 \mathrm{oz} /$ ton Ag (fig. C-1).

38 Placer River-Significant Mo-F mineralization disseminated in intrusive rocks. Reported values of $0.2 \%$ Mo (fig. C-2).

39 Fairhaven/Inmachuk district - Placer deposits with 348,089 oz production from 1902-2002; significant reserves remaining in a large ancestral channel system. Large base metal sulfide concentrations and $U$ values in concentrates (fig. C-3).

40 Poovookpuk Mountain - Porphyry Mo mineralization. Reported grades of up to $0.25 \%$ Mo (fig. C-2).

41 Purcell Mountain - Mo and Ag occurrences associated with Cretaceous alkalic igneous plutons, alaskite, and bostonite dikes (fig. C-2).

42 Koyukuk-Hughes mining district-Production of 258,344 oz Au from 1930 to 2002, mainly from Alaska Gold Co. dredge at Hogatza; dredge reactivated in 1981, but deactivated in 1984, and reactivated again in 1990. Nonfloat mechanized operation on Utopia Creek produced significant amount of placer Au from 1930 to 1962 (fig. C-3).

43 Iditarod district-Major placer Au district; produced 1,562,722 oz Au through 2002. Significant reserves of lode $\mathrm{Au}$ and lode $\mathrm{W}$ at Golden Horn deposit Chicken Mountain, and other known lodes in region associated with shear zones and monzonite intrusive rocks of Late Cretaceous age (fig. C-3).

44 Innoko-Tolstoi mining district-Major placer $\mathrm{Au}$ district with significant lode $\mathrm{Au}-\mathrm{Sb}-\mathrm{Hg}$ potential; lode 
sources for placers are Late Cretaceous volcanicplutonic complexes and dike swarms that intrude Mesozoic flysch; mining district produced 727,794 oz Au through 2002, almost all from placer deposits (fig. C-3).

45 Bonanza Creek-Skarn-type W mineralization along intrusive contact; no published information available (fig. C-2).

46 Ruby mining district-Placer $\mathrm{Au}-\mathrm{Sn}$ district; produced more than 477,477 oz Au from 1931 to 2002; mining district also contains $\mathrm{Pb}-\mathrm{Ag}$ prospects with grades reportedly as high as $82 \mathrm{oz} /$ ton $\mathrm{Ag}$ (fig. C-3).

47 Hot Springs mining district-Placer $\mathrm{Au}-\mathrm{Sn}$ district; produced more than $577,956 \mathrm{oz} \mathrm{Au}$ and over $720,000 \mathrm{lb}$ cassiterite through 2002. Includes Eureka and Tofty subdistricts. Magnetite-rich, niobium-bearing carbonatite sill in the Tofty area contains geochemically anomalous $\mathrm{Nb}$, REE, $\mathrm{P}$, and $\mathrm{Y}$ (figs. C-2, C-3).

48 Livengood-Tolovana mining district-Placer $\mathrm{Au}$ district; produced more than 529,466 oz Au since discovery in 1914 to 2002. Substantial reserves remain mainly on Livengood Bench, a Pliocene ancestral channel (fig. C-3).

49 Fairbanks mining district - Nationally ranked $\mathrm{Au}$ producing district; largest producer in Alaska. Produced about 8,174,987 oz Au from placer deposits (19022002). Major lode $\mathrm{Au}$ and lode $\mathrm{Sb}$ producer; produced more than 2,587,964 oz Au and over 2000 tons Sb from veins and shear zones through 2002. Production of W exceeded 4,000 short ton units since 1915, all derived from skarn near Cretaceous quartz monzonite (fig. C-3).

49a Fort Knox - Disseminated Au deposit within granodiorite/quartz monzonite pluton near Fairbanks. Proven and probable reserves as of December 31, 2000, open at depth, are 3,686,000 oz of Au in 138.4 million tons of rock at an average Au grade of $0.024 \mathrm{oz} /$ ton. Measured and indicated resources are 34.45 million tons containing 963,000 ounces of gold. Fairbanks Gold Mining Inc. at Fort Knox and True North mines produced 2,283,416 oz of Au from 1996 to 2002 (fig. C-3).

49b Ryan Lode - Based on a $0.015 \mathrm{oz} /$ ton cutoff, total reserves in the metasediment-hosted Ryan Lode and subparallel igneous-hosted Curlew Shear are 822,200 $\mathrm{oz}$ of $\mathrm{Au}$ in 14.6 million tons of rock. A geologic resource of about 2.4 million oz occurs within the total shear zone system (fig. C-3).

49c Grant Mine - A series of subparallel Au-bearing quartz veins in the schist and quartzite of Ester Dome based on exploration in 1990. Indicated reserves on one vein system, the O'Dea, are 212,000 tons of $0.36 \mathrm{oz} /$ ton $\mathrm{Au}$. Other similar vein systems have been identified within the property (fig. C-3).

49d True North - Au occurs in siderite-quartz veins in carbonaceous quartzite and schist within a terrane containing eclogitic rocks. The 2000 mineral inventory is 18.2 million tons grading $0.072 \mathrm{oz} /$ ton $\mathrm{Au}$ for a contained 1,314,000 oz Au. Mining began in 2001 and 20 million tons of $0.06 \mathrm{oz} /$ ton ore were processed at Fort Knox mill (fig. C-3).

49e Dolphin-Recently recognized mineralized intermediate intrusion contains anomalous $\mathrm{Au}, \mathrm{As}, \mathrm{Bi}$ and $\mathrm{Sb}$. Discovery hole in 1995 intercepted $330 \mathrm{ft}$ of $0.049 \mathrm{oz} /$ ton $\mathrm{Au}$ (fig. C-3).

49f Gil Claims - Gold occurs in two calc-silicate zones within Paleozoic schist units. Gold enrichment occurs along iron-stained shears and within quartz-calcite veinlets. Drilling has identified an in-place Au resource of $433,000 \mathrm{oz}$ at an average grade of $0.04 \mathrm{oz} /$ ton $\mathrm{Au}$ (fig. C-3).

50 Mt. Prindle - Significant U-rare-earth mineralization in Mesozoic alkaline igneous rocks. Rock geochemical values of up to $0.7 \% \mathrm{U}$; up to $15 \%$ rare-earth elements reported (fig. C-3).

51 Twin Mountain - Significant W mineralization associated with skarn development along contact zone of quartz monzonite stock of Cretaceous age (fig. C-2).

52 Circle mining district - Currently one of Alaska's largest producing placer $\mathrm{Au}$ districts; produced $1,062,005 \mathrm{oz} \mathrm{Au}$ since discovery in 1893 to 2002. Has significant potential for $\mathrm{Sn}, \mathrm{W}$, and $\mathrm{Au}$ mineralization from variety of lode sources (fig. C-3).

53 Three Castle Mountain, Pleasant Creek, Casca VABM-Stratabound $\mathrm{Pb}-\mathrm{Zn}$ massive-sulfide mineralization. Reported grades of up to $17 \% \mathrm{Zn}$ and $2 \% \mathrm{~Pb}$ (fig. C-1).

54 Bonnifield district massive-sulfide deposits (Anderson Mountain, Dry Creek, Sheep Creek, Virginia Creek, BT, Liberty Belle) - Significant volcanogenic $\mathrm{Cu}-\mathrm{Pb}-\mathrm{Zn}-\mathrm{Ag}$ massive-sulfide deposits of Devonian to Mississippian age in Bonnifield mining district. Potential for high-grade deposits reported. Includes Liberty Belle stratabound $\mathrm{Au}-\mathrm{B}$ deposit and mineralization in Sheep Creek; latter contains Sn as well as base metals (fig. C-1).

55 Delta massive-sulfide belt - Contains at least 30 known volcanogenic massive-sulfide deposits and occurrences. Grades from 0.3 to $1.1 \% \mathrm{Cu}, 1.7$ to $5.7 \%$ $\mathrm{Zn}, 0.5$ to $2.3 \% \mathrm{~Pb}, 0.7$ to $2.0 \mathrm{oz} / \mathrm{ton} \mathrm{Ag}$, and 0.018 to $0.061 \mathrm{oz} /$ ton $\mathrm{Au}$; estimated potential reserve of 40 million tons for all deposits. Recent exploration has identified several gold prospects associated with silicified structures in the White Gold trend (fig. C-1).

56 Mosquito, Peternie - Porphyry Mo prospects of early Tertiary age; reported grades of up to $0.17 \% \mathrm{Mo}$ (fig. C-2).

57 Taurus - Significant major porphyry $\mathrm{Cu}-\mathrm{Au}$ prospect of Paleocene age. East Taurus Zone contains inferred reserves of 140 million tons grading about $0.30 \% \mathrm{Cu}$ and $0.01 \mathrm{oz} /$ ton $\mathrm{Au}$, and $0.03 \% \mathrm{Mo}$ (fig. C-2).

58 Big Creek/Ladue - Stratabound $\mathrm{Pb}-\mathrm{Zn}-\mathrm{Ag}$ massivesulfide prospects in metavolcanic rocks (fig. C-1).

59 Slate Creek-At least 55 million tons of $6.3 \%$, high- 
quality chrysotile asbestos in serpentinized ultramafic rocks of Permian(?) age (fig. C-3).

60 Fortymile mining district-Major placer Au district. Produced over 548,114 oz placer and very minor lode Au since discovery in 1883 to 2002, the longest continuous production of $\mathrm{Au}$ (119 years) of any Alaskan mining district (fig. C-3).

61 Kantishna mining district-Major placer $\mathrm{Au}$ and lode $\mathrm{Ag}-\mathrm{Au}-\mathrm{Pb}-\mathrm{Zn}-\mathrm{Sb}-\mathrm{W}$ district. Produced 99,307 oz placer and lode $\mathrm{Au}$, about 307,000 oz lode $\mathrm{Ag}$, and 2,500 tons $\mathrm{Sb}$ from shear zones and vein deposits hosted in metamorphic units of Yukon-Tanana terrane. Nearly 90 lode deposits have been identified; potential exists for significant $\mathrm{Ag}-\mathrm{Au}-\mathrm{Pb}-\mathrm{Zn}$ resources. Metalliferous stratabound base metal deposits occur in schist and quartzite (fig. C-3).

62 Stampede mine - Major Sb deposit; produced more than 1,750 tons $\mathrm{Sb}$ from large shear zone in polymetamorphic rocks of Yukon-Tanana terrane (fig. C-3).

63 Coal Creek-Greisen-hosted $\mathrm{Sn}-\mathrm{Cu}-\mathrm{W}$ deposit in "McKinley" age pluton (55 million years old). Reported reserves of 5 million tons of ore that grade $0.28 \% \mathrm{Sn}$ and $0.3 \% \mathrm{Cu}$ with credits of $\mathrm{W}, \mathrm{Ag}$, and $\mathrm{Zn}$ (fig. C-2).

64 Golden Zone mine-Major $\mathrm{Au}-\mathrm{Cu}-\mathrm{Ag}$ deposits in Late Cretaceous breccia pipe and skarn deposits. Produced more than $1,581 \mathrm{oz} \mathrm{Au}, 8,617 \mathrm{oz} \mathrm{Ag}$, and 21 tons $\mathrm{Cu}$. On the basis of recent (1994) drilling, the Pipe, Bunkhouse, and Copper King deposits contain 13.3 million tons grading $0.095 \mathrm{oz} /$ ton $\mathrm{Au}$ (figs. C-1, C-3).

$65 \mathrm{Nim}$ Prospect-Porphyry $\mathrm{Cu}-\mathrm{Ag}-\mathrm{Au}$ deposit of Late Cretaceous age. Reported grades of up to $5.0 \% \mathrm{Cu}$ and 9 oz/ton Ag (fig. C-1).

66 Valdez Creek district-About 508,554 oz Au production through 2002. Cambior Alaska Inc., the largest placer mine in Alaska, operated in this district until September 1995 (fig. C-3).

67 Caribou Dome (Denali) - Ten identified stratabound $\mathrm{Cu}$ deposits in volcanic sedimentary rocks of Triassic age. Proven and probable ore is 700,000 tons grading $6 \% \mathrm{Cu}$ with $\mathrm{Ag}$ credits, with indicated resources that may contain 2 million tons ore over strike length of 4,000 ft (fig. C-1).

67a Zackly-Disseminated $\mathrm{Cu}$ and $\mathrm{Au}$ in a garnet-pyroxene skarn and marble. Reserves are estimated at 1.4 million tons grading 2.6 percent $\mathrm{Cu}$ and $0.175 \mathrm{oz} /$ ton $\mathrm{Au}$ (fig. C-1).

68 Chistochina-Porphyry $\mathrm{Cu}$ prospects of Tertiary age and placer Au district; produced more than 181,261 oz $\mathrm{Au}$ and small amount $\mathrm{Pt}$ from placer deposits (figs. C-2, C-3).

69 Nabesna mine - Classic high-grade Au skarn that envelopes quartz diorite of Jurassic(?) age; produced over $66,500 \mathrm{oz} \mathrm{Au}$ from about 88,000 tons of ore from 1930 to 1941 (fig. C-3).

70 Spirit Mountain-Massive and disseminated $\mathrm{Cu}-\mathrm{Ni}$ mineralization in mafic-ultramafic complex (fig. C-3).
71 Kennecott deposits-Major stratiform $\mathrm{Cu}-\mathrm{Ag}$ massivesulfide deposits localized near contact between Chitistone Limestone and Nikolai Greenstone of Triassic age; contained some of highest grade $\mathrm{Cu}$ lodes mined in North America. From 1911 to 1938, produced more than 600,000 tons $\mathrm{Cu}$ and 10 million oz Ag from 4.8 million tons ore. Some reserves remain (fig. C-1).

72 Binocular and other prospects-Kennecott-type $\mathrm{Cu}-$ Ag massive-sulfide deposits (fig. C-1).

73 Bond Creek-Orange Hill- - Two major porphyry $\mathrm{Cu}-$ Mo deposits of Late Cretaceous age; reported inferred reserves of 850 million tons ore that grade 0.3 to $0.5 \%$ $\mathrm{Cu}$ and $0.03 \% \mathrm{Mo}$ (fig. C-2).

74 Carl Creek-Porphyry $\mathrm{Cu}$ prospect in altered intrusive complex; similar to locality 73 (fig. C-2).

75 Baultoff-Porphyry $\mathrm{Cu}$ prospect in altered intrusive rocks; inferred reserves of 145 million tons of $0.20 \%$ $\mathrm{Cu}$; similar to locality 73 (fig. C-2).

76 Horsfeld-Porphyry $\mathrm{Cu}$ prospect; similar to locality 73 (fig. C-2).

77 Midas mine - Significant stratabound $\mathrm{Cu}(\mathrm{Ag}-\mathrm{Au}-\mathrm{Pb}-$ $\mathrm{Zn}$ ) massive-sulfide deposit in volcanic sedimentary rocks of Tertiary Orca Group. Produced more than 1,650 tons $\mathrm{Cu}$ from 49,350 tons ore (fig. C-1).

78 Ellamar-Stratabound $\mathrm{Cu}-\mathrm{Zn}$-Au massive-sulfide deposit in sediment of Eocene(?) Orca Group. Produced more than 8,000 tons $\mathrm{Cu}, 51,307 \mathrm{oz} \mathrm{Au}$, and 191,615 oz Ag from about 301,835 tons ore (fig. C-1).

79 Willow Creek, Independence, Lucky Shot, War Baby-Major lode $\mathrm{Au}$ deposits $(\mathrm{Ag}-\mathrm{Cu}-\mathrm{Pb}-\mathrm{Zn}-\mathrm{Mo})$ in veins that cut Mesozoic quartz diorite. Produced more than $606,400 \mathrm{oz} \mathrm{Au}$ from lode sources and about 55,600 $\mathrm{oz} \mathrm{Au}$ from associated placer deposits (fig. C-3).

80 Latouche, Beatson-Major stratabound $\mathrm{Cu}-\mathrm{Zn}-\mathrm{Ag}$ massive-sulfide deposits in Orca Group sedimentary rocks and mafic volcanic rocks. Produced more than 10,250 tons $\mathrm{Cu}$ from 6 million tons ore. Inferred reserves of 5 million tons ore that grade $1 \% \mathrm{Cu}, 1.5 \%$ $\mathrm{Pb}+\mathrm{Zn}$ (fig. C-1).

81 Rua Cove-Major stratabound $\mathrm{Cu}-\mathrm{Zn}$ massive-sulfide deposit in complex ore shoots enclosed in mafic volcanic rocks of Orca Group. Reported reserves of over 1.1 million tons ore that grade $1.25 \% \mathrm{Cu}$ (fig. $\mathrm{C}-1$ ).

82 Red Mountain and Claim Point-Significant $\mathrm{Cr}$ occurrence associated with layered ultramafic complexes of Tertiary age at Red Mountain near Seldovia. More than 39,951 tons of metallurgical-grade ore shipped through 1976; huge low-grade $\mathrm{Cr}$ resource may remain, of which 30 million tons grade $5.1 \% \mathrm{Cr}_{2} \mathrm{O}_{3}$ (fig. C-3).

83 Red Devil-Major Hg-Sb deposit; high-grade epithermal $\mathrm{Hg}-\mathrm{Sb}$ deposit hosted in shear zones in Kuskokwim Group sedimentary rocks. More than 35,000 flasks $\mathrm{Hg}$ produced from 75,000 tons ore (fig. C-3). 
84 Aniak district-Significant placer Au district. Aniak mining district produced 578,708 oz Au from placer deposits, mainly from the Nyac and Donlin Creek areas (fig. C-3).

85 Goodnews Bay-Major placer Pt district; estimated to have produced over 555,000 oz refined PGE metals from 1934 to 1976; one of the largest known PGE metal resources in United States. Possible resources of 60 million $\mathrm{yd}^{3}$ of deep, PGE-bearing gravels remain. Lode source believed to be Alaskan-type zoned ultramafic complex of Jurassic or Cretaceous age. Possible significant offshore placer potential (fig. C-3).

86 Apollo-Sitka mines-Major lode Au deposits; produced more than $107,600 \mathrm{oz} \mathrm{Au}$ from ore that averaged about $0.22 \mathrm{oz} /$ ton $\mathrm{Au}$. Inferred reserves are 748,000 tons grading $0.76 \mathrm{oz} /$ ton $\mathrm{Au}, 2.16 \mathrm{oz} / \mathrm{ton} \mathrm{Ag}$, with base metal credits (fig. C-3).

87 Pyramid-Late Tertiary porphyry $\mathrm{Cu}-\mathrm{Mo}$ deposit; inferred reserves of 125 million tons ore that grade $0.4 \% \mathrm{Cu}$ and $0.03 \%$ Mo reported (fig. C-2).

88 Ivanof-Late Tertiary porphyry $\mathrm{Cu}$ prospect; grades of up to $0.72 \% \mathrm{Cu}$ reported. Potential for large tonnages (fig. C-2).

89 Weasel Mountain, Bee Creek-Porphyry $\mathrm{Cu}-\mathrm{Mo}$ prospect of late Tertiary to Quaternary age; grades of up to $0.48 \% \mathrm{Cu}$ and $0.035 \%$ Mo reported. Potential for moderate tonnages of low-grade mineralization (fig. C2).

90 Mike deposit-Porphyry Mo prospect of late Tertiary age; grades of up to $0.21 \%$ Mo reported. Potential for large tonnages of low-grade Mo mineralization (fig. C-2).

91 Rex deposit - Porphyry $\mathrm{Cu}$ prospect similar to locality 90; grades of up to $0.3 \% \mathrm{Cu}$ reported. Potential for moderate reserves of low-grade mineralization (fig. C-2).

92 Kasna Creek-Major stratiform $\mathrm{Cu}-\mathrm{Pb}-\mathrm{Zn}$ and skarnsulfide deposits of Mesozoic age in mafic, volcanic, and sedimentary rocks; reported reserves of over 10 million tons ore that grade more than $1 \% \mathrm{Cu}$ (fig. $\mathrm{C}-1$ ).

93 Sleitat Mountain - High-grade east-west-trending, SnW-Ag topaz-quartz greisen system hosted in 59million-year-old granite and in hornfels. Zone up to $3,000 \mathrm{ft}$ long and $500 \mathrm{ft}$ wide. One drill-hole showed 85 $\mathrm{ft}$ of $1.8 \% \mathrm{Sn}$, and $0.4 \% \mathrm{~W}$. Inferred resources are 64,000 to 106,000 tons $\mathrm{Sn}$ in 29 million tons ore (fig. C-2).

94 Jimmy Lake - Complex $\mathrm{Cu}-\mathrm{Ag}-\mathrm{Sn}$ mineralization of late Tertiary(?) age; reported grades of up to $105 \mathrm{oz} / \mathrm{ton}$ $\mathrm{Ag}$ and $3 \% \mathrm{Cu}$ (fig. $\mathrm{C}-1$ ).

95 Haines Barite/Palmer-Major stratiform $\mathrm{Ba}-\mathrm{Pb}-\mathrm{Zn}-$ $\mathrm{Cu}-\mathrm{Ag}$ deposit in pillow basalt-dominated section of Paleozoic or Triassic age; consists of 48- to 60-ft-thick zone of $60 \%$ barite with upper zone ( 2 to $8 \mathrm{ft}$ thick) of massive sulfides that contain $2 \% \mathrm{~Pb}, 3 \% \mathrm{Zn}, 1 \% \mathrm{Cu}$, up to $4 \mathrm{oz} /$ ton $\mathrm{Ag}$, and $0.12 \mathrm{oz} /$ ton Au. Estimated to contain 750,000 tons of $65 \%$ barite with $\mathrm{Zn}$ and $\mathrm{Ag}$ credits (fig. C-1).

96 Klukwan-Major Fe-Ti deposits in zoned ultramafic complex of Mesozoic age; reported to contain 3 billion tons of material that contains $16.8 \% \mathrm{Fe}$ and 1.6 to $3.0 \%$ Ti (fig. C-3).

97 Nunatak-Porphyry Mo deposit; reported reserves of 2.24 million tons ore grading $0.067 \% \mathrm{Mo}, 0.16 \% \mathrm{Cu}$, and 129.5 million tons of $0.026 \% \mathrm{Mo}, 0.18 \% \mathrm{Cu}$ (fig. C-2).

98 Brady Glacier-Major $\mathrm{Ni}-\mathrm{Cu}$ deposit in layered gabbro-pyroxenite complex of Tertiary age. Proven reserves of 100 million tons ore that grade $0.5 \% \mathrm{Ni}$, $0.3 \% \mathrm{Cu}$ reported and about $0.03 \% \mathrm{Co}$; also contains PGE concentrations (fig. C-3).

99 Mertie Lode and Funter Bay mining districtContains substantial reserves of lode Au mineralization. Past production totaled about 15,000 oz Au. Deposits also contain significant $\mathrm{Ni}-\mathrm{Cu}$ and $\mathrm{Pb}-\mathrm{Zn}-\mathrm{Ag}$ mineralization. Funter Bay deposit contains reported reserves of 560,000 tons that grade $0.34 \% \mathrm{Ni}, 0.35 \% \mathrm{Cu}$, and $0.15 \%$ Co in gabbro-pipe system (fig. C-3).

100 Alaska-Juneau-Major lode Au deposit that consists of 100- to 300-ft-wide zone that contains en echelon, $\mathrm{Au}$-bearing quartz veins in metamorphic rocks; produced more than 3.52 million oz Au from 88.5 million tons ore from 1893 to 1944 . Reserves (all categories) of 105.7 million tons of $0.05 \mathrm{oz} / \mathrm{ton} \mathrm{Au}$ remain (fig. C-3).

101 Chichagof and Hirst Chichagof-Major lode $\mathrm{Au}$ deposits in quartz veins that cut Mesozoic graywacke; produced more than $770,000 \mathrm{oz} \mathrm{Au}$, most of which was produced at Chichagof Mine. Inferred leased reserves estimated to be 100,000 oz Au (fig. C-3).

102 Mirror Harbor- $-\mathrm{Ni}-\mathrm{Cu}$ mineralization in layered gabbro complex of Mesozoic age; reported proven reserves of 8,000 tons of $1.57 \% \mathrm{Ni}$ and $0.88 \% \mathrm{Cu}$ and reported inferred reserves of several million tons ore that grade $0.2 \% \mathrm{Ni}$ and $0.1 \% \mathrm{Cu}$ (fig. C-3).

103 Bohemia Basin-Major $\mathrm{Ni}-\mathrm{Cu}-\mathrm{Co}$ mineralization in layered mafic complex similar to locality 102 ; reported reserves of 22 million tons ore that grade 0.33 to $0.51 \%$ $\mathrm{Ni}, 0.21$ to $0.27 \% \mathrm{Cu}$, and $0.02 \% \mathrm{Co}$, all of which are recoverable with standard flotation technology (fig. C-3).

104 Apex-EI Nido - Significant lode $\mathrm{Au}-\mathrm{W}$ deposits that occur as crosscutting veins in graywacke; produced more than 50,000 oz Au (fig. C-3).

105 Greens Creek-Major sediment-hosted $\mathrm{Pb}-\mathrm{Zn}-\mathrm{Cu}-$ $\mathrm{Ag}-\mathrm{Au}$ volcanogenic massive-sulfide deposit of Devonian or Triassic age. Production from 1989 to 1993 and 1996 to 2002 is 557,675 tons of $\mathrm{Zn}, 216,275$ tons of $\mathrm{Pb}$, more than 8,600 tons of $\mathrm{Cu}, 95.4$ million oz of $\mathrm{Ag}$, and $661,481 \mathrm{oz}$ of $\mathrm{Au}$. The 2002 reserve estimate is 7 million tons grading $0.13 \mathrm{oz} /$ ton $\mathrm{Au}, 14.9 \mathrm{oz} /$ ton $\mathrm{Ag}, 11.4 \% \mathrm{Zn}$, and $4.2 \% \mathrm{~Pb}$. Resources are 2.7 million 
tons grading $11.3 \% \mathrm{Zn}, 4.9 \% \mathrm{~Pb}, 0.13 \mathrm{oz} /$ ton $\mathrm{Au}$, and $17 \mathrm{oz} /$ ton Ag. (fig. C-1).

106 Sumdum-Volcanogenic $\mathrm{Cu}-\mathrm{Pb}-\mathrm{Zn}$ massive-sulfide deposit in Mesozoic metamorphic complex with potential strike length of over 10,000 ft. Inferred reserves of 26.7 million tons ore that grade $0.57 \% \mathrm{Cu}$, $0.37 \% \mathrm{Zn}$, and $0.3 \mathrm{oz} /$ ton $\mathrm{Ag}$ reported (fig. C-1).

107 Snettisham-Fe-Ti deposit in mafic zoned intrusive complex; reported grades of about $18.9 \% \mathrm{Fe}$ and $2.6 \%$ Ti (fig. C-3).

108 Tracy Arm - Stratabound $\mathrm{Cu}-\mathrm{Zn}-\mathrm{Pb}$ massive-sulfide prospect in Mesozoic schist; over 1,100 ft long and up to $12 \mathrm{ft}$ thick. Reported grades of $1.5 \% \mathrm{Cu}, 3.9 \% \mathrm{Zn}$, $0.76 \mathrm{oz} /$ ton $\mathrm{Ag}$, and $0.013 \mathrm{oz} /$ ton $\mathrm{Au}$ (fig. C-1).

109 Red Bluff Bay — Significant chrome mineralization in Mesozoic ultramafic complex (probably ophiolite); reported reserves of 570 tons of material that grade $40 \%$ $\mathrm{Cr}$ and 29,000 tons that grade 18 to $35 \% \mathrm{Cr}$ (fig. C-3).

110 Cornwallis Peninsula-Volcanogenic $\mathrm{Cu}-\mathrm{Pb}-\mathrm{Zn}-\mathrm{Ag}-$ Ba massive-sulfide deposit of Triassic(?) age; reported grades of up to $20 \% \mathrm{~Pb}-\mathrm{Zn}$ and $23 \mathrm{oz} /$ ton $\mathrm{Ag}$ (fig. C-1).

111 Castle Island - Stratiform barite deposit of Triassic age hosted in carbonate and pillow basalt; about 856,000 tons of raw and refined barite produced from 1963 to 1980; also contains $\mathrm{Zn}, \mathrm{Pb}$, and $\mathrm{Cu}$ sulfides. Reported to be mined out (fig. C-1).

112 Groundhog Basin - Area contains several massivesulfide prospects in Mesozoic schist and gneiss whose origins are now thought to be plutonic associated. Reported grades of up to $8 \% \mathrm{~Pb}, 29 \mathrm{oz} /$ ton $\mathrm{Ag}$, and 0.5 oz/ton Au. Sn has also been recently identified. Area also contains potential for porphyry Mo deposits (fig. C-1).

113 Snipe Bay- $\mathrm{Ni}-\mathrm{Cu}$ deposit in zoned mafic-ultramafic complex; inferred reserves of 430,000 tons of $0.3 \% \mathrm{Ni}$, $0.3 \% \mathrm{Cu}$, and $0.13 \mathrm{oz} /$ ton $\mathrm{Ag}$ reported (fig. C-3).

114 Kasaan Peninsula-Major skarn-type $\mathrm{Cu}-\mathrm{Fe}-\mathrm{Au}$ massive-sulfide deposit of Jurassic age; area has produced over 14,000 tons $\mathrm{Cu}$, and 55,000 oz Ag. Reported reserves of 4 million tons ore that grade $50 \%$ $\mathrm{Fe}$ and less than $2 \% \mathrm{Cu}$ (fig. $\mathrm{C}-1$ ).

115 Salt Chuck- $\mathrm{Cu}-\mathrm{PGM}-\mathrm{Ag}-\mathrm{Au}$ deposit in contact zone between pyroxenite and gabbro within Alaskan-type zoned mafic-ultramafic pluton. From 1900 to 1941 , 2,500 tons $\mathrm{Cu}$, over 20,000 oz PGM, and $\mathrm{Au}$ and $\mathrm{Ag}$ credits were produced from 325,000 tons ore (fig. C-3).

116 Union Bay-Significant Fe-Ti mineralization in zoned, Ural-Alaska type ultramafic complex; area also contains PGE and V concentrations. At least six zones of PGEmagnetite hydrothermal mineralization are associated with pyroxene veins that crosscut magmatic layering (fig. C-3).

117 Hyder mining district - Area produced more than 25,000 tons high-grade $\mathrm{W}-\mathrm{Cu}-\mathrm{Pb}-\mathrm{Zn}-\mathrm{Ag}$ ore from 1925 to 1951 from crosscutting ore shoots in Texas
Creek granodiorite of Tertiary age. Area also contains potential for porphyry $\mathrm{Mo}-\mathrm{W}$ mineralization and massive-sulfide-skarn $\mathrm{Pb}-\mathrm{Ag}-\mathrm{Au}-\mathrm{W}$ deposits (figs. C-1, C-2).

118 Jumbo- $\mathrm{Cu}-\mathrm{Fe}-\mathrm{Mo}-\mathrm{Ag}$ skarn deposit; produced more than 5,000 tons $\mathrm{Cu}, 280,000 \mathrm{oz} \mathrm{Ag}$, and 7,000 oz Au from 125,000 tons ore. Zoned magnetite- $\mathrm{Cu}$ skarns are associated with epizonal granodiorite pluton of Cretaceous age. Reported reserves of 650,000 tons ore that grade $45.2 \% \mathrm{Fe}, 0.75 \% \mathrm{Cu}, 0.01 \mathrm{oz} /$ ton $\mathrm{Au}$, and $0.08 \mathrm{oz} /$ ton $\mathrm{Ag}$ (fig. C-1).

119 Copper City - Stratiform $\mathrm{Cu}-\mathrm{Zn}-\mathrm{Ag}-\mathrm{Au}$ massivesulfide deposit hosted in late Precambrian or earliest Paleozoic Wales Group. Reported grades of up to $12.7 \% \mathrm{Cu}, 2.7 \% \mathrm{Zn}, 2.5 \mathrm{oz} /$ ton $\mathrm{Ag}$, and $0.2 \mathrm{oz} /$ ton $\mathrm{Au}$ (fig. C-1).

120 Quartz Hill-A porphyry Mo deposit hosted in a 25million-year-old composite felsic pluton. Probable reserves are 232 million tons with a grade of $0.22 \%$ $\mathrm{MoS}_{2}$, and possible reserves are 1.2 billion tons with $0.12 \% \mathrm{MoS}_{2}$ (fig. C-2).

121 Niblack-Volcanogenic $\mathrm{Cu}-\mathrm{Pb}-\mathrm{Au}-\mathrm{Ag}$ massivesulfide deposit hosted in Precambrian(?) Wales Group or Ordovician to Silurian Descon Formation; produced more than 700 tons $\mathrm{Cu}, 11,000 \mathrm{oz} \mathrm{Au}$, and $15,000 \mathrm{oz}$ Ag. Current resource is 2.78 million tons at $3.22 \% \mathrm{Zn}$, $1.70 \% \mathrm{Cu}, 0.93 \mathrm{oz} /$ ton $\mathrm{Ag}$ and $0.081 \mathrm{oz} /$ ton $\mathrm{Au}$. (fig. C-1).

122 Bokan Mountain-Numerous U-Th prospects associated with Jurassic peralkaline intrusive complex; from 1955 to 1971, produced more than 120,000 tons ore that graded about $1 \% \mathrm{U}_{3} \mathrm{O}_{8}$. Contains inferred reserves of about 40 million tons of $0.126 \% \mathrm{Nb}$ and up to $1 \%$ REE metals (fig. C-3).

123 Kemuk Mountain-Magmatic Fe-Ti deposit hosted in Cretaceous(?) pyroxenite. Inferred reserves of 2.4 billion tons that average 15 to $17 \% \mathrm{Fe}, 2$ to $3 \% \mathrm{TiO}_{2}$, and $0.16 \% \mathrm{P}_{2} \mathrm{O}_{5}$ (fig. C-3).

124 McLeod-Porphyry Mo deposit that contains quartzmolybdenite fissure veins in quartz-feldspar porphyry. Chip samples contain up to $0.09 \%$ Mo (fig. C-2).

125 Johnson River-Epigenetic(?) quartz-sulfide stockwork or massive-sulfide deposit hosted in volcaniclastic, pyroclastic, and volcanic rocks of Jurassic Talkeetna Formation. Deposit has drilled-out reserves at a $\$ 45 /$ ton cutoff with no cut of high $\mathrm{Au}$ assays, $1,099,580$ tons grading $0.32 \mathrm{oz} /$ ton $\mathrm{Au}, 0.24 \mathrm{oz} /$ ton $\mathrm{Ag}, 0.76 \% \mathrm{Cu}, 1.17 \% \mathrm{~Pb}$, and $8.37 \% \mathrm{Zn}$ (fig. C-3).

126 Nimiuktuk River-Small hill of massive, high-grade barite estimated to contain at least 1.5 million tons barite. Widespread stream-sediment $\mathrm{Ba}$ anomalies in area indicate further barite potential (fig. C-1).

127 Kensington - Stockwork quartz veins in sheared and chloritized quartz diorite produced 10,900 tons grading $0.18 \mathrm{oz} /$ ton Au prior to 1930 . Recent estimates indicate at least 10.95 million tons grading $0.16 \mathrm{oz} /$ ton $\mathrm{Au}$ for 
$1,751,000 \mathrm{oz} \mathrm{Au}$ of proven and probable reserves. Subparallel Horrible vein system contains 3.93 million tons grading $0.11 \mathrm{oz} /$ ton $\mathrm{Au}$ (fig. C-3).

128 Jualin - Five quartz-fissure veins in Cretaceous quartz diorite, more than $15,000 \mathrm{ft}$ of underground workings; produced $48,387 \mathrm{oz} \mathrm{Au}$, mainly prior to 1930 . Reserves estimated at 1.07 million tons of $0.349 \mathrm{oz} /$ ton $\mathrm{Au}$ (fig. C-3).

129 Pebble Copper $-\mathrm{Cu}$-Au porphyry with identified resource of 1 billion tons grading $0.30 \% \mathrm{Cu}$ and 0.010 $\mathrm{oz} /$ ton $\mathrm{Au}$ with $\mathrm{Mo}$ in the 0.03 to $0.04 \%$ range. Mineralized system extends over a 35 -sq-mi area and includes other $\mathrm{Cu}-\mathrm{Au}-\mathrm{Mo}$ porphyry, $\mathrm{Cu}-\mathrm{Au}$ skarn, and $\mathrm{Au}$ vein prospects (fig. C-1).

130 Pogo-Au hosted in a series (3 discovered to date) of sub-parallel and tabular, gently dipping, quartz vein zones hosted by Paleozoic gneisses intruded by Cretaceous felsic plutonic rocks. Au in the $3 \mathrm{ft}$ to $60 \mathrm{ft}$ thick quartz bodies has a strong correlation with Bi. A 1999 conservative kriged geological resource for the Liese L1 and L2 zones is 10.7 million tons at an average grade of $0.524 \mathrm{oz} / \mathrm{ton}$, for a total of 5.6 million $\mathrm{oz}$ at a $0.1 \mathrm{oz} /$ ton cut-off grade. Other high-grade $\mathrm{Au}$ targets have been identified along an 8-mi-long trend southeast of the Liese zones (fig. C-3).

131 Shotgun Hills - Quartz stockwork and breccia $\mathrm{Au}-\mathrm{Cu}-$ As mineralization in a Late Cretaceous rhyolite (granite porphyry) stock. A preliminary, inferred Au resource of 980,000 oz (36.11 million tons at an average grade of $0.027 \mathrm{oz} /$ ton $\mathrm{Au}$ ) at a $0.016 \mathrm{oz} /$ ton Au cut-off grade, with initial metallurgical tests indicating $>90 \% \mathrm{Au}$ recovery by cyanide leaching (fig. C-3).

132 Illinois Creek- $\mathrm{Au}-\mathrm{Ag}-\mathrm{Cu}-\mathrm{Pb}-\mathrm{Zn}-\mathrm{Bi}-\mathrm{As}$-bearing, $\mathrm{Fe}-\mathrm{Mn}$ oxide (gossan) shear zone crosscutting dolomitic quartzite localized near Cretaceous granitic pluton. Shear zone averages $148 \mathrm{ft}$ wide, has a drilldefined east-west strike length of $11,600 \mathrm{ft}$, and is open along strike and depth. Produced approximately 126,000 oz Au and 600,000 oz Ag from 1997 to 2002. Past ore grade of $0.076 \mathrm{oz} /$ ton $\mathrm{Au}$ and $1.6 \mathrm{oz} / \mathrm{ton} \mathrm{Ag}$ (figs. C-1, C-3).

133 Calder Mine - Seven recrystallized carbonate units exposed at the apex of a large regional antiform. Drilling has identified 13 million tons of chemically homogenous, high-brightness, high-whiteness marble with a purity of 98 to $99 \%$ calcium carbonate. Potential resource of 80 million tons of high-value calcium carbonate (fig. C-2).

134 Vinasale Mountain - Intrusion-hosted Au deposit. Au mineralization is associated with arsenopyrite and pyrite in quartz-dolomite hydrothermal breccias, magmatic breccias, and zones of phyllic and silicic alteration hosted within a 69 Ma quartz monzonite stock. Both

\section{Alaska Mineral Industry 2002-Special Report 57}

disseminated and veinlet mineralization exist. An inferred resource of 14.35 million tons grading 0.067 $\mathrm{oz} /$ ton $\mathrm{Au}$, with an $0.03 \mathrm{oz} /$ ton cut-off grade was identified by drilling in the Central zone (fig. C-3).

135 Nixon Fork- $\mathrm{Au}-\mathrm{Cu}$ skarn deposits; Historic Nixon Fork mine produced 59,500 oz Au from Late Cretaceous skarns associated with quartz monzoniteDevonian limestone contact zones. Underground mining resumed in October 1995, with 133,900 oz of Au, 1,800 tons of $\mathrm{Cu}$, and significant $\mathrm{Ag}$ produced through mine closure in 1999 (fig. C-3).

136 Von Frank Mountain - Au and very weak $\mathrm{Cu}$ mineralization are associated with chalcopyrite, pyrite, and rare molybdenite within a zone of quartz stockwork veining hosted in a $69 \mathrm{Ma}$ quartz-diorite stock. The stock is a cupola of the larger Von Frank Pluton. Drill intercepts include up to $429 \mathrm{ft}$ wide with an average grade of $0.013 \mathrm{oz} /$ ton Au. Higher grade intercepts include 0.035 oz/ton Au up to $135 \mathrm{ft}$ (fig. C-3).

137 Donlin Creek-Au mineralization associated with disseminated pyrite and arsenopyrite, sulfide veinlets, and quartz-carbonate-sulfide veinlets in sericite-altered Late Cretaceous to early Tertiary rhyodacitic porphyry dikes and sills. Au mineralization is structurally controlled, refractory, and occurs along a 4-mi-long, 1mi-wide zone. Measured and indicated resource on November 2002 estimated at 8.26 million oz of Au grading $0.102 \mathrm{oz} /$ ton $\mathrm{Au}$ and an inferred resource of 14.83 million oz Au grading $0.102 \mathrm{oz} /$ ton $\mathrm{Au}$ at a 0.058 oz/ton Au cut-off grade. Considered the 25th largest gold resource in the world (fig. C-3).

138 Kaiyah-Au-Ag epithermal prospect in silicified Koyukuk sedimentary rocks adjacent to Poison Creek caldera. Polymetallic sulfides in quartz veins, with some veins over $100 \mathrm{ft}$ thick, and silicification are associated with pervasive advanced argillic, and sericite alteration (fig. C-3).

139 Shulin Lake - Micro- and macro-diamonds in interbedded volcaniclastic and tuffaceous rocks containing olivine and pyroxene. Discovered by tracing diamond indicator minerals in placer gravels. Possible lamproitic intrusions with up to 1-mi-diameter circular aeromagnetic anomalies (fig. C-3).

140 Canwell and Nikolai Complex- $-\mathrm{Ni}-\mathrm{Cu}-\mathrm{PGE}$ semimassive to massive-sulfide prospects hosted in mafic and ultramafic rocks of the Nikolai intrusive/extrusive complex. Five mafic-ultramafic intrusions in the central Alaska Range are comagmatic with the Nikolai flood basalts (fig. C-3).

141 Duke Island- $\mathrm{Cu}-\mathrm{Ni}-\mathrm{PGE}$ disseminated, semimassive, and massive-sulfides associated with two zoned, Ural-Alaska type ultramafic bodies (fig. C-3). 


\section{APPENDIX D \\ State and federal agencies and private interest groups involved in mineral development activities, 2002}

(The Alaska Miners Association Directory lists technical and professional consultants and companies available for work in Alaska. The report is published annually and is free to AMA members. The cost for non members is $\$ 15$ plus shipping and handling.)

\section{STATE OF ALASKA AGENCIES}

\author{
DEPARTMENT OF COMMUNITY AND ECONOMIC \\ DEVELOPMENT \\ State Office Building, 9th Fl. \\ P.O. Box 110800 (mailing) \\ Juneau, AK 99811-0800 \\ (907) 465-2500 \\ (907) 465-3767 (fax)
}

Function: Promotes economic development in Alaska.

Division of Trade and Development

550 W. 7th Ave., Ste. 1770

Anchorage, AK 99501

(907) 269-8110

(907) 269-8125 (fax)

Unit 7, 3677 College Rd.

Fairbanks, AK 99709

(907) 451-3050

(907) 451-3053 (fax)

email: swainbnk@ptialaska.net

Function: Primary state government advocacy agency for economic growth. Researches and publishes economic data on Alaska's mining industry. Attracts capital investment by advertising Alaska's resource potential. Provides research staff aid for the Alaska Minerals Commission. The Division also encourages the development of new markets for Alaska resources, increases the visibility of Alaska and its products in the international marketplace, and makes referrals and provides technical assistance to those interested in developing export markets for Alaska-produced or value-added goods and services.

Alaska Industrial Development \& Export Authority (AIDEA) 813 W. Northern Lights Blvd.

Anchorage, AK 99503

(907) 269-3000

(907) 269-3044 (fax)

http://www.aidea.org

Function: AIDEA provides capital to finance economic growth throughout Alaska-from multi-million-dollar mining projects to small, family-owned businesses; from urban centers to small towns and rural villages. Regardless of project size, location, or business type, all AIDEA-financed projects must enhance the state's economy and provide or maintain jobs for Alaskans. AIDEA's financing assistance programs - the Credit Program and the Development Finance Program - have played an important role in Alaska's mineral development. The Credit Program includes the Loan Participation, Business and Export Assistance loan guarantee, and the Tax-Exempt Revenue Bond programs. AIDEA's Development Finance Program allows AIDEA to develop, own, and operate facilities within Alaska such as roads, ports, and utilities which are essential to the economic well-being of an area; are financially feasible; and are supported by the community in which they are located.

\section{DEPARTMENT OF ENVIRONMENTAL CONSERVATION}

410 Willoughby Ave., Ste. 303

Juneau, AK 99801-1795

(907) 465-5365

(907) 465-5070(fax)

(907) 465-5040 TTY

(907) 465-5065 Commissioner's Office

(907) 465-5365 Public Information

Function: Issues permits for activities (including mining) that affect air or water quality or involve land disposal of wastes. Sets air- and water-quality standards. Inspects, monitors, and enforces environmental quality statutes, regulations, and permits. Reviews all federal permits.

Department of Environmental Conservation

Anchorage Office

555 Cordova St.

Anchorage, AK 99501-2617

(907) $269-7500$

(907) 269-7600 (fax)

(907) 269-7511 TYY

Permits/Compliance Assistance

1-800-510-2332 (inside Alaska only)

email: compass@envircon.state.ak.us

Department of Environmental Conservation

Fairbanks Office

610 University Ave.

Fairbanks, AK 99709-3643

(907) 451-2360

(907) 451-2188 (fax)

(907) 451-2184 TTY

\author{
DEPARTMENT OF FISH AND GAME \\ 1255 W. 8th St. \\ P.O. Box 25526 (mailing) \\ Juneau, AK 99802-5526 \\ (907) $465-4100$ \\ (907) 465-4759 \\ http://www.state.ak.us/adfg
}

DEPARTMENT OF NATURAL RESOURCES

Office of the Commissioner

400 Willoughby Ave., Ste. 500

Juneau, AK 99801-1724

(907) 465-2400

http://www.dnr.state.ak.us

Alaska Coastal Management Program

302 Gold St., Ste. 202

Juneau, AK 99801

(907) 465-3562

(907) 465-3075 (fax)

Function: Conducts coordinated State review of permits for mining projects within Alaska's Coastal Management Zone. Provides project design information to applicants for consistency with the policies and standards of the Alaska Coastal Management Program. Coordinates State response to direct federal actions, including proposed regulations, that affect Alaska's mining industry. 
Southcentral Regional Office

550 W. 7th Ave., Ste. 1660

Anchorage, AK 99501-3568

(907) 269-7470

(907) 269-3981 (fax)

\author{
Alaska Mental Health Trust Land Office \\ 550 W. 7th Ave., Ste. 1430 \\ Anchorage, AK 99501 \\ (907) 269-8658 \\ (907) 269-8905 (fax) \\ http://www.dnr.state.ak.us/mhtlo/
}

Function: The Trust Land Office (TLO) manages the approximately 1 million acres of land that are included in the Alaska Mental Health Trust, which was created by Congress in 1956. Lands in the Trust are located throughout the state and are used to generate revenues to meet the expenses of mental health programs in Alaska. Management activities include all aspects of land use and resource development, including mineral and oil and gas leasing, exploration, and development; material sales (including gravel, sand, and rock); timber sales; surface leasing; land sales; and issuance of easements across Trust land.

\author{
Office of Habitat Management \& Permitting \\ Headquarters \& Juneau Area Office \\ 400 Willoughby Ave., 4th Fl. \\ Juneau, AK 99801-1796 \\ (907) 465-4105 \\ (907) 465-4759 (fax)
}

Function: The Office of Habitat Management and Permitting fulfills specific statutory responsibilities for (1) protecting freshwater and anadromous fish habitat under the Anadromous Fish Act (AS 41.14.870) and (2) providing free passage of anadromous and resident fish in fresh waterbodies $(A S$ 41.14.840). It requires prior written authorizations for any work affecting the free movement of fish, for any use or activity that may affect designated anadromous fish waters, and for any disturbance-producing or habitat-altering activity.

Operations Manager \& Fairbanks Area Office 1300 College Rd.

Fairbanks, AK 99701-1551

(907) 459-7289

(907) 456-3091 (fax)

Anchorage Area Office

333 Raspberry Rd.

Anchorage, AK 99518-1599

(907) 267-2285

(907) 267-2464 (fax)

Kenai Area Office

514 Funny River Rd.

Soldotna, AK 99669-8255

(907) 260-4882

(907) 260-5992 (fax)

Mat-Su Area Office

1800 Glenn Highway, Ste. 12

Palmer, AK 99645-6736

(907) 745-7363

(907) 745-7369 (fax)

Petersburg Area Office

P.O. Box 667

Petersburg, AK 99833-0667

(907) 772-5224

(907) 772-9336 (fax)
Prince of Wales Area Office

P.O. Box 668

Craig, AK 99921-0668

(907) 826-2560

(907) 826-2562 (fax)

Division of Forestry

550 W. 7th Ave., Ste. 1450

Anchorage, AK 99501-3566

(907) 269-8463

http://www.dnr.state.ak.us/forestry

Function: Establishes guidelines to manage mining in state forests.

Northern Region Office

3700 Airport Way

Fairbanks, AK 99709-4699

(907) 451-2660

Coastal Region Office

400 Willoughby Ave., Ste. 300

Juneau, AK 99801

(907) 465-2494

Division of Geological \& Geophysical Surveys

3354 College Rd.

Fairbanks, AK 99709-3707

(907) 451-5000

(907) 451-5050 (fax)

email: dggs@dnr.state.ak.us

http://wwwdggs.dnr.state.ak.us

Function: Conducts geological and geophysical surveys to determine the potential of Alaska land for production of metals, minerals, fuels, and geothermal resources; locations and supplies of construction materials; potential geologic hazards to buildings, roads, bridges, and other installations and structures; and other surveys and investigations as will advance knowledge of the geology of Alaska (AS 41.08.020). Publishes a variety of reports and maintains a web site that contain the results of these investigations. Advises the public and government agencies on geologic issues. Maintains a library of geologic bulletins, reports, and periodicals. Maintains a geologic materials storage facility at Eagle River.

Geologic Materials Center

P.O. Box 772805

Eagle River, AK 99577-2805

(907) 696-0079

(907) 696-0078 (fax)

John_Reeder@dnr.state.ak.us

Division of Mining, Land \& Water

550 W. 7th Ave., Ste. 1070

Anchorage, AK 99501

(907) 269-8600

(907) 269-8904 (fax)

http://www.dnr.state.ak.us/mlw

\section{A. Mining}

Function: Principal agency for management of mining and reclamation on state land in Alaska. Maintains offices in Anchorage and Fairbanks. Issues property rights to leasable minerals; manages locatable mineral filings. Also issues millsite leases and permits for hard rock and placer mining activity. Maintains records of mineral locations, permits and leases. Provides technical, legal, and land-status information. Administers the Alaska Surface Mining Control and Reclamation Act 
(ASMCRA), which includes permitting and inspection of coal mining activity and reclamation of abandoned mines.

\section{B. Land}

Function: Manages surface estate and resources, including materials (gravel, sand, and rock). Handles statewide and regional land-use planning. Issues leases, material-sale contracts, land-use permits, and easements for temporary use of State land and access roads. Administers land sales program.

\section{Water Management}

Function: Manages water resources of the State; issues waterrights permits and certificates; responsible for safety of all dams in Alaska.

Mining Information:

Anchorage (907) 269-8642

Fairbanks (907) 451-2793

All other Land \& Water Information:

Northern Regional Office

3700 Airport Way

Fairbanks, AK 99709-4699

(907) 451-2740

(907) 451-2751 (fax)

Southcentral Regional Office

550 W. 7th Ave., Ste. 900A

Anchorage, AK 99501

(907) 269-8503

(907) 269-8947 (fax)

Southeast Regional Office

400 Willoughby Ave., Ste. 400

Juneau, AK 99801-1724

(907) 465-3400

(907) 586-2954 (fax)

E-mail: sero@dnr.state.ak.us

Division of Parks and Outdoor Recreation

550 W. 7th Ave., Ste. 1310

Anchorage, AK 99501-3565

(907) 269-8700

Function: Manages approximately 3,000,000 acres of state park lands primarily for recreational uses, preservation of scenic values, and watershed. Responsible for overseeing mining access, recreational mining activity, and valid mining-claim holdings within state park lands. The Office of History and Archaeology reviews mining permit applications on all lands within the state for impacts to historic resources.

Northern Regional Office

3700 Airport Way

Fairbanks, AK 99709-4699

(907) 451-2695

Southeast Regional Office

400 Willoughby Ave., 5th Fl.

Juneau, AK 99801-1724

(907) 465-4563

Office of History and Archaeology

550 W. 7th Ave., \#1310

Anchorage, AK 99501-3565

(907) 269-8721

(907) 269-8908 (fax)

email: stefaniej@dnr.state.ak.us

\section{DEPARTMENT OF PUBLIC SAFETY}

450 Whittier St.

P.O. Box 111200 (mailing)

Juneau, AK 99811-1200

(907) 465-4322

Alaska Bureau of Wildlife Enforcement

5700 East Tudor Rd.

Anchorage, AK 99507-1225

(907) 269-5589

Function: Enforces state laws, in particular AS Title 16. Protects Alaska's fish and wildlife resources through enforcement of laws and regulations governing use of natural resources within Alaska. These laws are in Alaska Statutes 8, 16, 46, and Alaska Administrative Codes 5, 12, and 20.

\section{DEPARTMENT OF REVENUE}

State Office Bldg.

11th Fl., Entrance A

P.O. Box 110400 (mailing)

Juneau, AK 99811-0400

(907) 465-2300

http://www.revenue.state.ak.us

\section{Tax Division}

State Office Bldg., 11th Fl., Entrance B

P.O. Box 110420 (mailing)

Juneau, AK 99811-0420

(907) 465-2320

(907) 465-2375 (fax)

email: fish_excise@revenue.state.ak.us

http://www.tax.state.ak.us

Function: Issues licenses for mining, production, and sale of minerals. Administers mining-license tax based on net income, including royalties. New mining operations-except sand and gravel mining - can apply for and receive certificates of tax exemption for the first $3 \frac{1}{2}$ years of operation. (Tax returns must be filed annually.)

\section{UNIVERSITY OF ALASKA}

\section{College of Science, Engineering, and Mathematics}

Department of Geology \& Geophysics

P.O. Box 755780

Natural Sciences Building, Room 308

University of Alaska Fairbanks

Fairbanks, AK 99775-5780

(907) 474-7565

(907) 474-5163 (fax)

email: geology@www.uaf.edu

http://www.uaf.edu/geology

Function: Provides undergraduate and graduate education in geology and geophysics and conducts basic and applied research in geologic sciences. For undergraduate studies, the department offers a B.A. program in Earth Science and a B.S. program in Geology (with emphasis options in general geology, economic geology, and petroleum geology). For graduate studies, the department offers M.S. and Ph.D. programs in Geology and Geophysics, with concentrations in: General geology; economic geology; petroleum geology; Quaternary geology; remote sensing; volcanology; solid-earth geophysics; and snow, ice, and permafrost geophysics. 
School of Mineral Engineering

P.O. Box 755960

Duckering Building, Room 357

University of Alaska Fairbanks

Fairbanks, AK 99775-5960

(907) 474-7366

(907) 474-6994 (fax)

email: FYSME@uaf.edu

http://www.uaf.edu/sme

Function: Provides undergraduate and graduate education programs in geological engineering, mining engineering, mineral preparation engineering, and petroleum engineering. Through research programs conducts laboratory and field studies to promote mineral and energy development.

Mineral Industry Research Laboratory (MIRL)

School of Mineral Engineering

P.O. Box 757240

Duckering Building, Room 357

University of Alaska Fairbanks

Fairbanks, AK 99775-7240

(907) 474-6746

(907) 474-5400 (fax)

Function: Conducts applied and basic research in exploration, development, and utilization of Alaska's mineral and coal resources with emphasis on coal characterization, coal utilization, coal upgrading, coal preparation, mineral beneficiation, fine gold recovery, hydrometallurgy, and environmental concerns. Publishes reports on research results and provides general information and assistance to the mineral industry.

Dept. of Mining \& Geological Engineering

School of Mineral Engineering

P.O. Box 755800

Duckering Building, Room 301

University of Alaska Fairbanks

Fairbanks, AK 99775-5800

(907) 474-7388

(907) 474-6635 (fax)

email: FYSME@uaf.edu

http://www.uaf.edu/sme

Function: Teaching research and public service; support of the mineral industry.

Mining and Petroleum Training Service

155 Smith Way, Ste. 101

University of Alaska Anchorage

Soldotna, AK 99669

(907) 262-2788

(907) 262-2812 (fax)

email: mapts@alaska.net

http://www.alaska.net/ mapts

Function: Provides direct training and assistance to mine operators, service and support companies, and governmental agencies in mine safety and health, mining extension, vocational mine training, and technical transfer. Specialized training services in hazardous materials, first aid and CPR, industrial hygiene, and professional safety education and consulting are available on demand.

\section{FEDERAL AGENCIES}

\author{
U.S. DEPARTMENT OF THE INTERIOR \\ Office of the Secretary \\ 1689 C St., Ste. 100 \\ Anchorage, AK 99501-5151 \\ (907) 271-5485 \\ (907) 271-4102
}

Function: Coordinates the Department of the Interior's policy and stewardship with DOI bureaus for the management of more than 200 million acres of public land in Alaska.

\section{Bureau of Land Management}

Alaska State Office

Division of Lands, Minerals, and Resources

222 West 7th Ave., Ste. 13

Anchorage, AK 99513-7599

Public Information Center (907) 271-5960

Northern Field Office (907) 474-2252

Public Information Center

http://www.ak.blm.gov/

Energy Branch (907) 271-5608

Solid Minerals Branch (907) 271-5608

\section{Division Functions:}

BLM is the surface manager of federal public lands (except national parks, wildlife refuges, national monuments, national forests, and military withdrawals). The Division is responsible for developing and coordinating statewide and regional program management policies and strategies related to federal onshore energy and non-energy leasable minerals, mineral assessments, and locatable minerals. It provides technical assistance and coordinates activities relating to ANILCA 1010 mineral assessments. The Division provides the basis for economic analysis relating to energy and mineral development in the state. It also provides leadership and technical assistance on abandoned mine lands inventories and impacts on public lands.

\section{Energy Branch Functions:}

The Branch is responsible for the federal onshore mineral leasing programs and functions; including oil and gas, geothermal resources, coal, and other energy and non-energy minerals. The Branch prepares and conducts oil and gas lease sales and is responsible for preparing pre- and post-lease sale fair market value evaluations for National Petroleum Reserve-Alaska leasing, and issuing leases; adjudicates oil and gas leases, transfers, and bonds; approves oil and gas industry operations for federal onshore oil and gas leases; protects federal lands from drainage of oil and gas resources, and inspects industry operations for compliance; and coordinates with other federal surface management agencies for the leasing and monitoring of minerals operations under their jurisdictions.

\section{Solid Minerals Branch Functions:}

The Branch maintains mining claim and mineral patent case files and electronic public minerals records related to those files. It adjudicates federal mining claim recordation filings, annual assessment affidavits, and timely payment of annual claim holding fees. It also adjudicates mineral survey and patent applications, and serves contest complaints for all federal lands in Alaska. The Branch conducts mineral assessments that aid environmentally 
sound development of a viable mineral industry in Alaska. Emphasis is on field programs that identify the type, amount, and distribution of mineral deposits in Alaska. Field information is augmented by studies of economic feasibility, and economic and environmental effects of mineral development. Information is provided to government agencies to aid land-planning and landuse decisions, and to the private sector to identify targets of opportunity for further exploration and/or development.

Anchorage Field Office

6881 Abbott Loop Rd.

Anchorage, AK 99507-2599

(907) $267-1246$

(907) 267-1267 (fax)

Glennallen Field Office

P.O. Box 147

Glennallen, AK 99588

(907) $822-3217$

(907) 822-3120 (fax)

http://www.glennallen.ak.blm.gov

Kotzebue Field Station

P.O. Box 1049

Kotzebue, AK 99752-1049

(907) 442-3430

(907) 442-2720 (fax)

Nome Field Station

P.O. Box 925

Nome, AK 99762-0925

(907) 443-2177

(907) 443-3611 (fax)

Northern Field Office

1150 University Ave.

Fairbanks, AK 99709-3899

(907) 474-2200

(907) 474-2251 Public Room

(907) 474-2282 (fax)

1-800-437-7021

Tok Field Station

P.O. Box 309

Tok, AK 99780

(907) 883-5121

(907) 883-5123 (fax)

Juneau Office

John Rishel Mineral Information Center

100 Savikko Rd.

Mayflower Island

Douglas, AK 99824

(907) 364-1553

(907) 364-1574 (fax)

email: jalbrech@ak.blm.gov

http://juneau.ak.blm.gov

Function: As a part of the minerals branch, in addition to the assessments and studies described above, the Mineral information Center has a special library which contains 20,000 geologic and minerals publications, and provides a variety of information services; plus displays of Alaskan rocks, minerals, and mining artifacts.
U.S. Fish and Wildlife Service

Region 7 Office

1011 East Tudor Rd.

Anchorage, AK 99503

(907) 786-3542

http://www.r7.fws.gov/

Function: Administers the federal public lands in national wildlife refuges, issues special-use permits for activities on refuges,

reviews permits and applications for various mining activities on all private and public lands and waters, and provides information to regulatory agencies on fish and wildlife and their habitat. Makes recommendations to regulatory agencies to mitigate adverse environmental impacts.

U.S. Fish and Wildlife Service

Fairbanks Fish and Wildlife Field Office

101 12th Ave.

Box No. 19

Fairbanks, AK 99701

(907) 456-0327

(907) 456-0208 (fax)

U.S. Fish and Wildlife Service

Juneau Fish and Wildlife Field Office

3000 Vintage Blvd., Ste. 201

Juneau, AK 99801-7100

(907) 586-7240

(907) 586- 7154 (fax)

U.S. Fish and Wildlife Service

Anchorage Fish and Wildlife Field Office

605 West 4th Ave., Rm. G-61

Anchorage, AK 99501

(907) 271-2888

(907) 271-2786 (fax)

U.S. Geological Survey

Alaska Science Center

Geologic Science Office

4200 University Dr.

Anchorage, AK 99508-4667

(907) 786-7479

The mission of the USGS Alaska Science Center (ASC) is to provide scientific leadership and accurate, objective, and timely data, information, and research findings about the earth and its flora and fauna to Federal and State resource managers and policy makers, local government, and the public to support sound decision making regarding natural resources, natural hazards, and ecosystems in Alaska and circumpolar regions.

Geologic Discipline programs in the ASC are based on insightful monitoring, assessments, and research activities that address natural hazards, earth resources, and geologic processes. The Geologic Discipline provides comprehensive, high quality, and timely scientific information to decision makers at Federal, State, and local government levels, as well as the private sector. The Minerals Program investigates and reports on the occurrence, quality, quantity, and environmental characteristics of mineral resources in Alaska, the processes that create and modify them, models for assessing mineral endowment, and the potential impacts of mineral development. 
U.S. Geological Survey

Alaska Science Center

Geographic Science Office

Earth Science Information Center

4230 University Dr., Suite 101

Anchorage, AK 99508-4664

(907) 786-7009

Function: Publishes and distributes all available topographic maps of Alaska, digital products, and aerial photography.

National Park Service

Alaska Regional Office

Physical Resources

2525 Gambell St.

Anchorage, AK 99503-2892

(907) 257-2632

(907) 257-2448 (fax)

Function: Administers lands within the national park system in Alaska. Manages oil and gas operations and pre-existing valid mining claims in parklands through plans of operation under Mining in Parks Act, National Park Service regulations, and other applicable federal and state laws and regulations.

\section{U.S. DEPARTMENT OF LABOR}

Mine Safety and Health Administration

2070 Peabody Rd., Suite 710

Vacaville, CA 95687

(707) $447-9842$

(707) 447-9432 (fax)

email: bowen.ayers@dol.gov

Mine Safety and Health Administration

Anchorage Federal Building

US Courthouse - Rm. 126

222 West 7th Ave., Box 30

Anchorage, AK 99513

(907) 271-1250

(907) 271-1252 (fax)

email: bowen.ayers@dol.gov

Function: Administers health and safety standards to protect the health and safety of metal, nonmetal, and coal miners. Cooperates with the State to develop health and safety programs and develops training programs to help prevent mine accidents and occupationally caused diseases. Under agreement with the Coal Mine Safety and Health Office, the MSHA metal/nonmetal section has assumed responsibility for enforcement and training activities at coal mines in Alaska.

Mine Safety and Health Administration

Coal Mine Safety and Health, District 9

P.O. Box 25367

Denver, CO 80225

(303) 231-5458

(303) 231-5553 (fax)

http://www.msha.gov

Function: Administers health and safety standards according to the Code of Federal Regulations to protect the health and safety of coal miners; requires that each operator of a coal mine comply with these standards. Cooperates with the State to develop health and safety programs and develops training programs to help prevent coal or other mine accidents and occupationally caused diseases in the industry.

\section{U.S. DEPARTMENT OF AGRICULTURE}

Forest Service

Regional Office, R.L.M.
P.O. Box 21628

Juneau, AK 99802-1628

(907) 586-7869

(907) 586-7866 (fax)

email: jkato@ffs.fed.us

http://www.fs.fed.us/

http://www.fs.fed.us/r10earth/

Function: With the Bureau of Land Management, provides joint administration of general mining laws on national forest system lands. Cooperates with Department of Interior agencies in the review and issuance of mineral leases. Issues permits for disposal of sand, gravel, and stone.

\section{U.S. ENVIRONMENTAL PROTECTION AGENCY}

Region 10 Regional Office

1200 6th Ave., MS OW-130

Seattle, WA 98101

(206) 553-1200

(206) 553-1746 (NPDES permits)

http://www.epa.gov/r10earth/

Function: Issues National Pollutant Discharge Elimination System (NPDES) permits under the Clean Water Act to regulate effluent discharges. Implements a compliance enforcement program. Maintains regulatory and review authority over wetland and NEPA/EIS-related issues.

Alaska Operations Office

222 West 7th Ave., Rm. 537

222 W. 7th Ave., Box 19 (mailing)

Anchorage, AK 99513-7588

(907) 271-5083

Alaska Operations Office

709 W 9th St., Rm. 223A

Box 20370 (mailing)

Juneau, AK 99802-0370

(907) 586-7619

\section{U.S. DEPARTMENT OF THE ARMY}

Corps of Engineers

Regulatory Branch

2204 3rd St.

P.O. Box 6898

Elmendorf Air Force Base, AK 99506-6898

(907) 753-2712

(907) $753-5567$ (fax)

(800) 478-2712 (in Alaska only)

http://www.poa.usace.army.mil/reg

Function: Regulates structures or work in navigable waters of the U.S. and discharge of dredged or fill material into U.S. waters, including wetlands. Under Section 404 of the Clean Water Act, the Corps of Engineers issues dredge and fill permits for certain mining activities in waters of the United States. Examples of regulated mining activities include construction of berms, dikes, diversions, ponds, overburden stripping, stockpiling, and reclamation activities.

\section{COOPERATIVE STATE-FEDERAL AGENCIES}

Alaska Public Lands Information Center

250 Cushman St., Ste. 1A

Fairbanks, AK 99701

(907) 456-0527

(907) 456-0514 (fax)

(907) 456-0532 (TDD for hearing impaired)

http://www.nps.gov/aplic 
Function: Clearinghouse for general information on outdoor recreation in Alaska. Information sources include U.S. Forest Service, U.S. Fish and Wildlife Service, U.S. Bureau of Land Management, U.S. Geological Survey, National Park Service, Alaska Departments of Natural Resources, Fish and Game, and Community and

Economic Development.

\section{BOARDS AND COMMISSIONS}

\section{Alaska Minerals Commission}

Irene Anderson, Chair

c/o Sitnasuak Native Corp.

P.O. Box 905

Nome, AK 99762

(907) 443-2632

(907) 443-4023

(907) 443-3063 (fax)

email: Ianderson@snc.org

Function: The Minerals Commission was created by the Alaska State Legislature in 1986 to make recommendations to the Governor and the Legislature on ways to mitigate constraints on the development of minerals in Alaska. The Commission has published annual reports since 1987.

\section{CHAMBERS OF COMMERCE}

Alaska State Chamber of Commerce

217 Second St., Ste. 201

Juneau, AK 99801

(907) $586-2323$

(907) 463-5515 (fax)

http://www.alaskachamber.com

Function: The State Chamber of Commerce researches and formulates positions on Alaskan resource development. Recommendations for consideration are submitted to the State Chamber of Commerce board of directors.

Anchorage Chamber of Commerce

441 West 5th Ave., Ste. 300

Anchorage, AK 99501

(907) 272-2401

email: info@anchoragechamber.org

http://www.anchoragechamber.org

Function: To be effective as a business leader by supporting and focusing its broad-based membership in their efforts to grow Anchorage into a premier American city.

Greater Fairbanks Chamber of

Commerce

250 Cushman St., Ste. 2D

Fairbanks, AK 99701-4665

(907) 452-1105

(907) 456-6968 email: staff@fairbankschamber.org

http://www.fairbankschamber.org

Juneau Chamber of Commerce

3100 Channel Dr., Ste. 300

Juneau, AK 99801

(907) 463-3488

(907) 463-3489 (fax)

email: juneauchamber@gci.net

http://www.juneauchamber.org

\section{PUBLIC INTEREST GROUPS AND ASSOCIATIONS}

Alaska Miners Association Inc.

Statewide Office

3305 Arctic Blvd., Ste. 105

Anchorage, AK 99503

(907) 563-9229

(907) 563-9225 (fax)

email: ama@alaskaminers.org

http://www.alaskaminers.org

Denali Branch of AMA

P.O. Box 1000

Healy, AK 99743

(907) 683-2226

email: keith@usibelli.com

Fairbanks Branch of AMA

P.O. Box 73069

Fairbanks, AK 99707-3069

(907) 479-9450

paulcmpy@alaska.net

Juneau Branch of AMA

10430 Dock St.

Juneau AK 99801-8522

(907) 789-6800

email: twelker@alaska.net

Kenai Branch of AMA

155 Smithway, \#101

Soldotna, AK 99669-3503

(907) 262-2788

mapts@alaska.net

Nome Branch of AMA

P.O. Box 1107

Nome, AK 99762-1107

(907) 443-5168

bktweet@nook.net

American Institute of

Professional Geologists

8703 Yates Dr., Ste. 200

Westminster, CO 80031-3681

(303) 412-6205

(303) 253-9220 (fax)

email: aipg@aipg.org

http://www.aipg.org

Alaska Section

P.O. Box 242672

Anchorage, AK 99524-2672

(907) 336-5361
Earthjustice

325 Fourth St.

Juneau, AK 99801

(907) 586-2751

(907) 463-5891 (fax)

http://www.earthjustice.org

National Wildlife Federation

750 W. Second Ave., Ste. 200

Anchorage, AK 99501

(907) 339-3900

(907) 339-3980 (fax)

Neighborhood Mine Watch

P.O. Box 84531

Fairbanks, AK 99708-4531

(907) 452-5021, ext. 28

email: nmw@mosquitonet.com

Northern Alaska Environmental Center

830 College Rd.

Fairbanks, AK 99701-1535

(907) 452-5021

(907) 452-3100 (fax)

email: info@northern.org

http://www.northern.org

Northwest Mining Association

10 North Post St., Ste. 220

Spokane, WA 99201

(509) 624-1158

(509) 623-1241 (fax)

email:nwma@nwma.org

http://www.nwma.org

Resource Development

Council for Alaska, Inc.

121 W. Fireweed Ln., Ste. 250

Anchorage, AK 99503

(907) 276-0700

(907) 276-3887 (fax)

email: Resources@akrdc.org

http://www.akrdc.org

Society for Mining, Metallurgy, and

Exploration Inc.

P.O. Box 277002

Littleton, CO 80127-7002

(303) 973-9550

(303) 973-3845 (fax)

email: sme@smenet.org

http://www.smenet.org

Southeast Alaska Conservation Council (SEACC)

419 6th St., Ste. 200

Juneau, AK 99801

(907) 586-6942

(907) 463-3312 (fax)

email: info@seacc.org

http://www.seacc.org

Trustees for Alaska

1026 W. 4th Ave., \# 201

Anchorage, AK 99501-1980

(907) 276-4244

email: ecolaw@trustees.org

http://www.trustees.org 


\section{ORGANIZED MINING DISTRICTS}

Circle Mining District

P.O. Box 30153

Central, AK 99730

(907) 488-6058

Fairbanks Mining District

105 Dunbar

Fairbanks, AK 99701

(907) 456-7642

Haines Mining District

P.O. Box 149

Haines, AK 99827

(907) 766-2821

Iditarod Mining District

John A. Miscovich

P.O. Box 87

Red Devil, AK 99656

Livengood-Tolovana Mining District

Rose Rybachek

P.O. Box 55698

North Pole, AK 99705

(907) 488-6453

Yentna Mining District

Carol Young

P.O. Box 211

Talkeetna, AK 99676

(907) 733-2351

\section{MINERAL EDUCATION} PROGRAMS

\section{ALASKA MINERAL AND ENERGY} RESOURCE EDUCATION FUND (AMEREF)

121 W. Fireweed Ln., Ste. 250

Anchorage, AK 99503

(907) 276-0700

(907) 276-3887 (fax)

email: resources@akrdc.org

http://www.ameref.org

Function: A 501(c)(3) educational nonprofit formed to help provide Alaska's students with the knowledge to make informed decisions on mineral, energy, and forest resources.

Alaska Department of Education and Early Development

801 W. 10th St., Ste. 200

Juneau, AK 99801-1894

(907) 465-2826

(907) 465-3396 (fax)

email: Cynthia Curran@eed.state.ak.us

http://www.eed.state.ak.us/tls/minerals/ minerals.html
NATIVE REGIONAL CORPORATIONS

AHTNA INC.

Main Office

P.O. Box 649

Glennallen, AK 99588-0649

(907) 822-3476

(907) 822-3495 (fax)

http://www.ahtna-inc.com/

Anchorage Office

406 W. Fireweed, S uite 104

Anchorage, AK 99503

(907) $868-8235$

(907) 868-8234 (fax)

THE ALEUT CORP.

4000 Old Seward Hwy., Ste. 300

Anchorage, AK 99503-6087

(907) $561-4300$

(907) 563-4328 (fax)

email:aleut@alaska.net

http://www.aleutcorp.com

ARCTIC SLOPE REGIONAL CORP.

P.O. Box 129

Barrow, AK 99723-0129

(907) 852-8633

(907) 852-5733 (fax)

http://www.asrc.com/

Anchorage Office

3900 C St., Suite 801

Anchorage, AK 99503-5963

(907) 339-6000

(907) 339-6028 (fax)

BERING STRAITS NATIVE CORP.

P.O. Box 1008

Nome, AK 99762-1008

(907) 443-5252

(907) 443-2985 (fax)

email: jimmy@beringstraits.com

http://www.beringstraits.com/

BRISTOL BAY NATIVE CORP.

800 Cordova St., Ste. 200

Anchorage, AK 99501-3717

(907) 278-3602

(907) 276-3924 (fax)

http://www.bbnc.net

\section{CALISTA CORP.}

301 Calista Court, Ste. A

Anchorage, AK 99518-3028

(907) 279-5516

(907) 272-5060 (fax)

http://www.calistacorp.com/
CHUGACH ALASKA CORP.

560 E. 34th Ave.

Anchorage, AK 99503-4196

(907) 563-8866

(907) 561-6961 (fax)

email: rrogers@chugach-ak.com

http://www.chugach-ak.com/

COOK INLET REGION INC.

and its subsidary North Pacific

Mining Corporation

2525 C St., Suite 500

Anchorage, AK 99503

(907) 274-8638

(907) 263-5190 (fax)

email: kmcgee@ciri.com

http://www.ciri.com/

DOYON LTD.

1 Doyon Place, Ste. 300

Fairbanks, AK 99701-2941

(907) 459-2030

(907) 459-2062 (fax)

email: lands@doyon.com

http://www.doyon.com

KONIAG INC.

4300 B St., Ste. 407

Anchorage, AK 99503

(907) 561-2668

(907) 562-5258 (fax)

http://www.koniag.com/

NANA REGIONAL CORP.

P.O. Box 49

Kotzebue, AK 99752

(907) 442-3301

(907) 442-2866 (fax)

http://www.nana.com

Anchorage Office

P.O. Box 241449

Anchorage, AK 99524-1449

(907) 265-4100

(907) 265-4123 (fax)

SEALASKA CORP.

One Sealaska Plaza, Ste. 400

Juneau, AK 99801

(907) 586-1512

(907) 586-2304 (fax)

http://www.sealaska.com/ 


\section{APPENDIX E Alaska Mining Websites \\ Mining and Exploration Companies}

Abacus Mining \& Exploration Co.

Alaska Earth Sciences Inc.

Alaska Freegold Co.

Anchorage Sand and Gravel Co. Inc.

Anglo Gold Ltd.

Avalon Development Corp.

Browns Hill Quarry

CanAlaska Ventures Ltd.

Chapleau Resources Ltd.

Coeur d'Alene Mines Corp. (Coeur Alaska Inc.)

Continental Ridge Resources Inc. (now Nevada Geothermal Power Inc.)

Copper Ridge Explorations Inc.

Engineer Mining Corp.

Freegold Ventures

Golconda Resources Ltd.

Grayd Resource Corp.

Hecla Mining Co.

Inlet Resources Ltd.

Kennecott Exploration Co.

Kennecott Minerals Co.

Kinross Gold Corp.

LAPP Resources Inc.

Navigator Exploration Corp.

Nevada Star Resources Corp.

Northern Associates Inc.

Northern Dynasty Minerals Ltd.

NovaGold Resources Inc.

Placer Dome Inc.

Quaterra Resources Inc.

Red Diamond Mining Co. Inc.

Rimfire Minerals Corp.

Rio Fortuna Exploration Corp.

Rubicon Minerals Corp.

Santoy Resources Ltd.

Shear Minerals Ltd.

Silverado Gold Mines Ltd.

Sisyphus Consulting

Teck Cominco Ltd.

Teryl Resources Corp.

TNR Resources Ltd.

Tri-Valley Corp.

Usibelli Coal Mine Inc.

Ventures Resource Corp.

Western Keltic Mines Inc.

WGM Inc. http://www.amemining.com

http://www.aes.alaska.com

http://www.freegoldventures.com

http://www.anchsand.com

http://www.anglogold.com

http://www.avalonalaska.com

http://www.brownshill.com

http://www.canalaska.com

http://www.chapleauresources.com

http://www.coeur.com

http://www.continentalridge.com/geothermal-gold.htm

http://www.copper-ridge.com

http://www.emcorp.yk.ca

http://www.freegoldventures.com

http://www.golcondaresources.com

http://www.grayd.com

http://www.hecla-mining.com

http://www.inlet-resources.com

http://www.kennecottexploration.com

http://www.kennecottminerals.com

http://www.kinross.com

http://home.gci.net/ lapres

http://www.navigatorexploration.com

http://www.nevadastar.com

http://www.alaskaexploration.com

http://www.northerndynastyminerals.com

http://www.novagold.net

http://www.placerdome.com

http://www.quaterraresources.com

http://www.reddiamondmining.com

http://www.rimfire.bc.ca

http://www.riofortuna.com

http://www.rubiconminerals.com

http://www.santoy.ca

http://www.shearminerals.com

http://www.silverado.com

http://sisyphus-consulting.com

http://www.teckcominco.com

http://www.terylresources.com

http://www.tnrgoldcorp.com

http://www.tri-valleycorp.com

http://www.usibelli.com

http://www.venturesresource.com

http://www.keltic.com

http://www.wgm.com

\section{Alaska Native Corporations}

Ahtna Inc.

Aleut Corp.

Arctic Slope Regional Corp.

Bering Straits Native Corp.

Bristol Bay Native Corp. http://www.ahtna-inc.com

http://www.aleutcorp.com

http://www.asrc.com

http://www.beringstraits.com

http://www.bbnc.net 
Calista Corp.

Chugach Alaska Corp.

Cook Inlet Region Inc.

Doyon Ltd.

Koniag Inc.

NANA Regional Corp.

Sealaska Corp. http://www.calistacorp.com

http://www.chugach-ak.com

http://www.ciri.com

http://www.doyon.com

http://www.koniag.com

http://www.nana.com

http://www.sealaska.com

\section{General}

Alaska Miners Association

Alaska Resource Data Files

Alaska Division of Geological \& Geophysical Surveys

Alaska Division of Community \& Business Development http://www.alaskaminers.org http://ardf.wr.usgs.gov

http://www.dggs.dnr.state.ak.us

http://www.dced.state.ak.us/cbd

Alaska's Minerals Data and Information Rescue in Alaska (MDIRA) Project Websites

Alaska Mining Claims Information System

Alaska Resource Data Files

DGGS Maps On-Line

DGGS Publications On-Line

Digital Index of Geological Information

DNR Sites Related to Mining Applications and Forms

Guide to Alaska Geologic and Mineral Information

Land Records Web Application

NURE Data

On-Line Annual Payments

RASS, PLUTO Geochemistry Data

State Map Library

State Recorder's Office Search

State Uniform Commerical Code (UCC) Documents Search http://www.dnr.state.ak.us/mcis

http://ardf.wr.usgs.gov

http://www.dggs.dnr.state.ak.us/gisexampl3.html http://www.dggs.dnr.state.ak.us/pubs.html http://imcg.wr.usgs.gov/digi.html http://www.dnr.state.ak.us/mlw/forms http://wwwdggs.dnr.state.ak.us/Libguide/ intropage.htm

http://www.dnr.state.ak.us/landrecords http://imcg.wr.usgs.gov/nuredata.html https://nutmeg.state.ak.us/ixpress/dnr/case/ lasmenu.dml http://geopubs.wr.usgs.gov/open-file/of99-433 http://www.dnr.state.ak.us//ris/gis_maplib/ maplib_start.cfm http://www.dnr.state.ak.us/ssd/recoff/search.cfm http://www.dnr.state.ak.us/ssd/ucc/search.cfm 
APPENDIX F

\section{U.S. Customary Units/Metric Units Conversion Chart}

To convert from:

To:

Multiply by:

\begin{tabular}{|c|c|c|}
\hline \multicolumn{3}{|c|}{ Weight/Mass/Ore Content } \\
\hline ounces (avoirdupois) & grams & 28.350 \\
\hline ounces (troy) & grams & 31.1035 \\
\hline pounds & kilograms & 0.4536 \\
\hline short tons & metric tons & 0.9072 \\
\hline grams & ounces (avoirdupois) & 0.03527 \\
\hline & ounces (troy) & 0.03215 \\
\hline kilograms & pounds & 2.2046 \\
\hline metric tons & short tons & 1.1023 \\
\hline parts per million (ppm) & parts per billion (ppb) & 1,000 \\
\hline parts per million (ppm) & ounces per ton & 0.0292 \\
\hline parts per million (ppm) & grams/metric tons (tonnes) & 1.00 \\
\hline \multicolumn{3}{|c|}{ Length } \\
\hline miles & kilometers & 1.6093 \\
\hline yards & meters & 0.9144 \\
\hline \multirow[t]{3}{*}{ feet } & meters & 0.3048 \\
\hline & centimeters & 30.48 \\
\hline & millimeters & 304.80 \\
\hline \multirow[t]{2}{*}{ inches } & centimeters & 2.54 \\
\hline & millimeters & 25.4 \\
\hline kilometers & miles & 0.6214 \\
\hline \multirow[t]{2}{*}{ meters } & yards & 1.0936 \\
\hline & feet & 3.2808 \\
\hline \multirow[t]{2}{*}{ millimeters } & feet & 0.00328 \\
\hline & inches & 0.03937 \\
\hline centimeters & inches & 0.3937 \\
\hline \multicolumn{3}{|c|}{ Area } \\
\hline square miles & square kilometers & 2.590 \\
\hline \multirow{2}{*}{ acres } & square meters & $4,046.873$ \\
\hline & hectares & 0.4047 \\
\hline square yards & square meters & 0.8361 \\
\hline square feet & square meters & 0.0929 \\
\hline \multirow[t]{2}{*}{ square inches } & square centimeters & 6.4516 \\
\hline & square millimeters & 645.16 \\
\hline square kilometers & square miles & 0.3861 \\
\hline \multirow[t]{3}{*}{ square meters } & acres & 0.000247 \\
\hline & square feet & 10.764 \\
\hline & square yards & 1.196 \\
\hline \multirow[t]{2}{*}{ hectares } & acres & 2.471 \\
\hline & square meters & $10,000.00$ \\
\hline square centimeters & square inches & 0.155 \\
\hline square millimeters & square inches & 0.00155 \\
\hline \multicolumn{3}{|c|}{ Volume } \\
\hline cubic yards & cubic meters & 0.7646 \\
\hline cubic feet & cubic meters & 0.02832 \\
\hline cubic inches & cubic centimeter & 16.3871 \\
\hline \multirow[t]{2}{*}{ cubic meters } & cubic yards & 1.3079 \\
\hline & cubic feet & 35.3145 \\
\hline cubic centimeters & cubic inches & 0.06102 \\
\hline gallons (U.S.) & liters & 3.7854 \\
\hline liters & gallons (U.S.) & 0.2642 \\
\hline milliliters & ounces (fluid) & 0.03381 \\
\hline ounces (fluid) & milliliters & 29.5735 \\
\hline
\end{tabular}

Temperature conversions:

From degrees Fahrenheit to degrees Celsius, subtract 32 and multiply by 5/9.

From degrees Celsius to degrees Fahrenheit, multiply by $9 / 5$ and add 32 . 
APPENDIX G

Primary metals production in Alaska, 1880-2002

\begin{tabular}{|c|c|c|c|c|c|c|c|c|c|c|c|c|c|c|c|c|c|c|c|c|}
\hline \multirow[b]{2}{*}{ Year } & \multicolumn{2}{|c|}{ Gold } & \multicolumn{2}{|c|}{ Silver } & \multicolumn{2}{|c|}{ Mercury } & \multicolumn{2}{|c|}{ Antimony } & \multicolumn{2}{|c|}{ Tin } & \multicolumn{2}{|c|}{ Lead } & \multicolumn{2}{|c|}{ Zinc } & \multicolumn{2}{|c|}{ Platinum } & \multicolumn{2}{|c|}{ Copper } & \multicolumn{2}{|c|}{ Chromium } \\
\hline & (oz) & $(\mathrm{m} \$)$ & (oz) & $(\mathrm{t} \$)$ & (flask $\left.{ }^{b}\right)$ & $(\mathrm{t} \$)$ & (lb) & $(\mathrm{t} \$)$ & (lb) & $(\mathrm{t} \$)$ & (tons) & $(\mathrm{t} \$)$ & (tons) & $(\mathrm{t})$ & (oz) & $(\mathrm{t})$ & (lb) & $(\mathrm{m} \$)$ & (tons) & $(\mathrm{t} \$)$ \\
\hline $\begin{array}{r}1880- \\
1899\end{array}$ & $1,153,889$ & 23.85 & 496,101 & 329.0 & $-\cdot$ & $-\cdot$ & $-\cdot$ & $-\cdot$ & $-\cdot$ & $-\cdot$ & 250 & 17.0 & -. & -. & $-\cdot$ & $-\cdot$ & -- & -- & $-\cdot$ & -. \\
\hline 1900 & 395,030 & 8.17 & 73,300 & 45.5 & -- & -. & -. & -. & -. & -- & 40 & 3.4 & -. & -. & -- & -. & -- & -. & -. & -- \\
\hline 1901 & 335,369 & 6.93 & 47,900 & 28.6 & -- & -. & -- & -- & -- & $-\cdot$ & 40 & 3.4 & -- & -- & -- & -- & 250,000 & 0.04 & $-\cdot$ & -. \\
\hline 1902 & 400,709 & 8.28 & 92,000 & 48.5 & -. & -. & -. & -. & 30,000 & 8.0 & 30 & 2.5 & -. & -. & -. & .- & 360,000 & 0.04 & -. & -. \\
\hline 1903 & 420,069 & 8.68 & 143,600 & 77.8 & -. & -. & -. & -. & 50,000 & 14.0 & 30 & 2.5 & .. & .- & .. & .. & $1,200,000$ & 0.16 & -. & .- \\
\hline 1904 & 443,115 & 9.16 & 198,700 & 114.9 & -. & -. & -. & .. & 28,000 & 8.0 & 30 & 2.5 & -. & -. & -. & .- & $2,043,586$ & 0.28 & -. & -. \\
\hline 1905 & 756,101 & 15.63 & 132,174 & 80.2 & -- & -. & -- & -. & 12,000 & 4.0 & 30 & 2.6 & -. & -. & -. & .- & $4,805,236$ & 0.75 & -. & -. \\
\hline 1906 & $1,066,030$ & 22.04 & 203,500 & 136.4 & -. & -. & -. & -. & 68,000 & 38.6 & 30 & 3.4 & .- & -. & -. & .. & $5,871,811$ & 1.13 & -. & -. \\
\hline 1907 & 936,043 & 19.35 & 149,784 & 98.8 & -- & -. & -- & -- & 44,000 & 16.8 & 30 & 3.2 & -- & -- & -- & -- & $6,308,786$ & 1.26 & -. & -. \\
\hline 1908 & 933,290 & 19.29 & 135,672 & 71.9 & -- & -. & -- & -. & 50,000 & 15.2 & 40 & 3.4 & -- & .. & -. & -. & $4,585,362$ & 0.61 & -. & -. \\
\hline 1909 & 987,417 & 20.41 & 147,950 & 76.9 & -. & -- & -. & -. & 22,000 & 7.6 & 69 & 5.9 & -. & .. & -. & .. & $4,124,705$ & 0.54 & -. & .- \\
\hline 1910 & 780,131 & 16.13 & 157,850 & 85.2 & -- & -. & -- & -. & 20,000 & 8.3 & 75 & 6.6 & -. & -. & -. & .. & $4,241,689$ & 0.54 & -- & .- \\
\hline 1911 & 815,276 & 16.85 & 460,231 & 243.9 & .- & -. & -- & .. & 122,000 & 52.8 & 51 & 4.5 & .- & -. & .. & .. & $27,267,778$ & 3.40 & -. & -. \\
\hline 1912 & 829,436 & 17.14 & 515,186 & 316.8 & -. & -. &.- & -. & 260,000 & 119.6 & 45 & 4.1 & -. & -. & -. & -. & $29,230,491$ & 4.82 & -. & -. \\
\hline 1913 & 755,947 & 15.63 & 362,563 & 218.9 & -- & -. & -- & -. & $100,000^{\mathrm{c}}$ & $44.1^{\mathrm{c}}$ & 6 & 0.6 & -. & -. & -- & -- & $21,659,958$ & 3.35 & -. & -. \\
\hline 1914 & 762,596 & 15.76 & 394,805 & 218.3 & -. & -. & -. & -. & 208,000 & 66.6 & 28 & 1.3 & -. & -. & -. & .- & $21,450,628$ & 2.85 & -. & .- \\
\hline 1915 & 807,966 & 16.70 & $1,071,782$ & 543.3 & -- & -. & 520,000 & w & 204,000 & 78.8 & 437 & 41.1 & -. & -. & -. & .- & $86,509,312$ & 15.14 & -. & .- \\
\hline 1916 & 834,068 & 17.24 & $1,379,171$ & 907.4 & - &.- & $1,200,000$ & w & 278,000 & $\begin{array}{r}121.0 \\
121.0\end{array}$ & 820 & $\begin{array}{l}113.2 \\
113.2\end{array}$ & -. & -. & 8 & 0.7 & $119,654,839$ & 29.50 & -- & -. \\
\hline 1917 & 709,049 & 14.66 & $1,239,150$ & $1,020.6$ &.- & -. & $\begin{array}{r}500,000 \\
5\end{array}$ & W & 200,000 & 123.3 & 852 & 146.6 & -. & -. & 53 & 5.5 & $88,793,400$ & 24.40 & 1,100 & W \\
\hline 1918 & 458,641 & 9.48 & $\begin{array}{r}847,789 \\
\end{array}$ & 847.8 & .- & -. & 540,000 & w & 136,000 & 118.0 & 564 & 80.1 & .- & -. & 284 & 36.6 & $69,224,951$ & 17.10 & 1,100 & W \\
\hline 1919 & 455,984 & 9.42 & 629,708 & 705.3 & -. & .. & & .. & 112,000 & 73.4 & 687 & 72.1 & .. & -. & 569 & 73.7 & $47,220,771$ & 8.80 & , & -. \\
\hline 1920 & 404,683 & 8.37 & 953,546 & $1,039.7$ & -. & -. & -. & -. & 32,000 & 16.1 & 875 & 140.0 & -. & -. & 1,478 & 160.1 & $70,435,363$ & 13.00 & -. & -. \\
\hline 1921 & 390,558 & 8.07 & 761,085 & 761.1 & 45 & 1.5 & -. & .. & 8,000 & 2.4 & 759 & 68.3 & -. & -. & 40 & 2.7 & $57,011,597$ & 7.40 & -. & .- \\
\hline 1922 & 359,057 & 7.42 & 729,945 & 729.9 & -. & -. & -- & -- & 2,800 & 0.9 & 377 & 41.5 & -. & -. & 29 & 2.8 & $77,967,819$ & 10.50 & $-\cdot$ & -. \\
\hline 1923 & 289,539 & 5.98 & 814,649 & 668.1 & -- & -. & -. & .. & 3,800 & 1.6 & 410 & 57.4 & -. & .. & -. & - - & $85,920,645$ & 12.60 & -. & .- \\
\hline 1924 & 304,072 & 6.29 & 669,641 & 448.6 & 2 & 0.3 & -. & -. & 14,000 & 7.1 & 631 & 100.9 & .. & .. & 28 & 2.6 & $74,074,207$ & 9.70 & -. & -. \\
\hline 1925 & 307,679 & 6.36 & 698,259 & 482.4 & 44 & 3.6 & W & w & 28,600 & 15.4 & 789 & 140.6 & .. & .. & 10 & 1.2 & $73,055,298$ & 10.30 & -. & -. \\
\hline 1926 & 324,450 & 6.70 & 605,190 & 377.0 & 22 & 1.7 & w & w & 16,000 & 10.4 & 778 & 124.4 & .. & .. & 3,570 & 274.5 & $67,778,000$ & 9.49 & .- & .- \\
\hline 1927 & 286,720 & 5.97 & 350,430 & 215.0 &.- & -. & - & .. & 53,400 & 34.0 & 1,008 & $\begin{array}{l}127.0 \\
\end{array}$ & -. & -. & - & -. & $55,343,000$ & 7.25 & -. & -. \\
\hline 1928 & 331,140 & 6.85 & 351,730 & & -. & -. & -. & -. & 82,000 & 41.0 & 1,019 & 118.0 & -. & -. & 120 & 9.0 & $41,421,000$ & 5.96 & -. & .- \\
\hline 1929 & 375,438 & 7.76 & 472,900 & 252.0 & 4 & 0.5 & -. & .. & 77,200 & 35.0 & 1,315 & 166.0 & -. & .. & 475 & 32.0 & $40,570,000$ & 7.13 & -. & .. \\
\hline 1930 & 408,983 & 8.47 & 408,570 & 157.3 & & -. & -- & -. & 29,400 & 9.3 & 1,365 & 136.5 & -. & -. & & & $32,651,000$ & 4.24 & -. & -. \\
\hline 1931 & 459,000 & 9.51 & 352,000 & 102.0 & 15 & 1.2 & -- & -. & 8,200 & 2.0 & 1,660 & 126.0 & -. & -. & 393 & 14.0 & $22,614,000$ & 1.88 & -. & .- \\
\hline 1932 & 493,860 & 10.20 & 234,050 & 66.0 & 8 & 0.5 & -. & .. & & -. & $\begin{array}{l}1,260 \\
-100\end{array}$ & 75.6 & -. & -. & -. & -. & $8,738,500$ & 0.55 & -. & -. \\
\hline 1933 & 469,286 & 9.70 & 154,700 & 55.0 & -- & -. & -- & -. & 5,800 & 2.3 & 1,157 & 85.6 & -. & -- & 605 & 18.6 & 29,000 & 0.02 & -- & .- \\
\hline 1934 & 537,281 & 8.78 & 154,700 & 100.0 & -. & -. & -- & -. & $8,200^{\mathrm{c}}$ & 4.3 & 839 & 62.1 & -- & -- & 2,555 & 85.6 & 121,000 & 0.06 & -. & -. \\
\hline 1935 & 469,495 & 16.43 & 286,600 & 206.0 & -. & -. & .- & .. & 98,800 & 49.8 & 815 & 65.2 & -. & -. & 8,685 & 259.6 & $15,056,000$ & 1.25 & -. & .. \\
\hline 1936 & 540,580 & 18.92 & 484,306 & 375.0 & -- & -. & & .. & 226,000 & 105.0 & 941 & 86.6 & -. & -. & 5,654 & 241.9 & $39,267,000$ & 3.72 & -. & -. \\
\hline 1937 & 627,940 & 21.98 & 494,340 & 382.0 & -- & -. & 962,000 & 147.6 & $372,000^{\mathrm{c}}$ & $202.3^{\mathrm{c}}$ & 823 & 97.1 & -. & -. & 9,823 & 313.4 & $36,007,000$ & 4.74 & -. & -. \\
\hline 1938 & 662,000 & 23.17 & 479,853 & 310.0 & 8 & 0.6 & 444,000 & 54.8 & 210,000 & 89.1 & 994 & 91.5 & -. & -. & 41,000 & $2,460.0$ & $29,760,000$ & 2.98 & -. & .- \\
\hline 1939 & 676,780 & & 201,054 & 136.5 & & & 210,000 & 25.9 & 66,000 & 38.0 & 937 & & -. & -. & 33,900 & $2,034.0$ & 278,500 & 0.04 & -. & .- \\
\hline 1940 & 755,900 & 26.45 & 191,679 & 136.3 & $156^{\mathrm{C}}$ & 130.9 & 306,000 & 42.8 & 92,000 & 52.0 & 840 & 72.0 & -. & -. & 28,886 & $1,093.0$ & 110,000 & 0.02 & -. & -. \\
\hline 1941 & 692,314 & 24.23 & 199,700 & 142.0 & W & W & 774,000 & 87.3 & $93,600^{\mathrm{c}}$ & $61.0^{\mathrm{c}}$ & 742 & 58.0 & -- & -- & 22,630 & 813.0 & 144,000 & 0.02 & $-\cdot$ & -. \\
\hline 1942 & 487,657 & 17.07 & 135,200 & 96.0 & W & W & 316,000 & 41.0 & 5,600 & 2.5 & 523 & 44.0 & -. & -. & 22,000 & 779.0 & 48,000 & 0.01 & -. & \\
\hline 1943 & 99,583 & 3.49 & 31,700 & 22.0 & 786 & 153.4 & 368,000 & 33.3 & $2,000^{\mathrm{c}}$ & $1.0^{\mathrm{c}}$ & 200 & 22.0 & -. & -. & 27,900 & $1,020.0$ & 54,000 & 0.01 & 5,564 & 186.3 \\
\hline 1944 & 49,296 & 1.73 & 15,240 & 10.8 & 841 & 165.0 & 70,080 & 30.0 & -. & -. & 44 & 5.8 & -. & -. & 33,616 & $2,017.0$ & 4,000 & 0.01 & 1,845 & 64.6 \\
\hline 1945 & 68,117 & 2.38 & 9,983 & 6.2 & 275 & 180.0 & W & W & -. & -. & 11 & 1.8 & -. & -. & 22,949 & $1,377.0$ & 10,000 & 0.01 & -. & -. \\
\hline 1946 & 226,781 & 7.93 & 41,793 & 26.3 & 699 & 68.7 & W & w & -. & -. & 115 & 25.0 & -- & & 22,882 & $1,418.7$ & 4,000 & 0.01 & -. & .. \\
\hline 1947 & 279,988 & 9.79 & 66,150 & 46.3 & 127 & 10.6 & 52,000 & 16.1 & 2,000 & 2.2 & 255 & 76.5 & 226 & 0.15 & 13,512 & $1,351.2$ & 24,000 & 0.06 & -. & .. \\
\hline 1948 & 248,395 & 8.69 & 67,341 & 58.7 & 108 & 7.8 & 88,000 & 29.3 & 10,000 & 10.8 & 317 & 88.9 & 226 & 0.15 & 13,741 & $1,209.2$ & 28,000 & 0.07 & -. & .. \\
\hline 1949 & 229,416 & 8.03 & 36,056 & 32.4 & 102 & 7.9 & 88,000 & 31.3 & 114,000 & 100.8 & 49 & 11.2 & 226 & 0.15 & 17,169 & $1,545.2$ & 7,700 & 0.02 & -. & .. \\
\hline
\end{tabular}


APPENDIX G (continued)

\begin{tabular}{|c|c|c|c|c|c|c|c|c|c|c|c|c|c|c|c|c|c|c|c|c|}
\hline \multirow[b]{2}{*}{ Year } & \multicolumn{2}{|c|}{ Gold } & \multicolumn{2}{|c|}{ Silver } & \multicolumn{2}{|c|}{ Mercury } & \multicolumn{2}{|c|}{ Antimony } & \multicolumn{2}{|c|}{ Tin } & \multicolumn{2}{|c|}{ Lead } & \multicolumn{2}{|c|}{ Zinc } & \multicolumn{2}{|c|}{ Platinum } & \multicolumn{2}{|l|}{ Copper } & Chr & mium \\
\hline & (oz) & (m\$) & (oz) & $(\mathrm{t} \$)$ & $\left(\right.$ flask $\left.^{\mathrm{b}}\right)$ & $(\mathrm{t} \$)$ & & $(\mathrm{t} \$)$ & (lb) & $(\mathrm{t} \$)$ & (tons) & $(\mathrm{t} \$)$ & (tons) & $(\mathrm{t} \$)$ & (oz) & $(\mathrm{t} \$)$ & & $(\mathrm{m} \$)$ & (tons) & $(\mathrm{t} \$)$ \\
\hline 1950 & 289,285 & 10.13 & 52,638 & 48.0 & W & W & $\mathrm{W}$ & W & 158,000 & 170.3 & 144 & 27.5 & -.- & $-\cdot$ & W & W & 12,000 & 0.03 & -- & -- \\
\hline 1951 & 239,628 & 8.38 & 32,870 & 29.8 & 28 & W & $1,718,000$ & $2,061.6$ & 138,000 & 198.0 & 21 & 7.2 & -- & -- & W & W & 2,000 & 0.01 & -- & \\
\hline 1952 & 240,571 & 8.42 & 31,825 & 28.7 & 40 & W & 740,000 & $1,406.0$ & 180,000 & 243.9 & 1 & 0.3 & -. & -- & w & w & -. & -. & w & W \\
\hline 1953 & 253,771 & 8.88 & 35,387 & 32.1 & 1,023 & 270.0 & W & W & 98,000 & 105.9 & -- & - - & -- & -. & 17,489 & $1,696.4$ & -- & & W & w \\
\hline 1954 & 248,511 & 8.70 & 33,694 & 31.8 & 1,046 & 276.0 & -- & -. & 398,000 & 409.9 & -- & & -- & -- & 18,790 & $1,615.9$ & 8,000 & 0.02 & 2.953 & 208.0 \\
\hline 1955 & 249,294 & 8.73 & 33,693 & 30.4 & 43 & 12.0 & & & 172,000 & 182.5 & 1 & 0.3 & -- & -. & 17,253 & $1,466.5$ & 2,000 & 0.01 & 7,082 & 625.3 \\
\hline 1956 & 204,300 & 7.33 & 26,700 & 24.1 & 3,414 & 837.0 & 134,400 & 150.0 & -- & -- & 1 & 0.3 & -. & -. & 17,934 & $1,829.3$ & -. & -. & 7,200 & 711.5 \\
\hline 1957 & 215,467 & 7.54 & 28,862 & 26.0 & 5,461 & $1,349.0$ & 71,120 & 80.0 & -. & .- & 9 & 3.0 & -. & -. & 15,479 & $1,377.6$ & -- & & 4,207 & 431.0 \\
\hline 1958 & 186,000 & 6.53 & 24,000 & 22.0 & 3,380 & 774.0 & -- & -. & .. & .. & .. & .- & .. & .. & 10,284 & 647.9 & 10,000 & 0.03 & -. & -. \\
\hline 1959 & 171,000 & 5.99 & 22,000 & 20.0 & 3,750 & 852.0 & -- & -. & -. & -. & -- & -. & -. & -. & 10,698 & 770.3 & 72,000 & 0.04 & -. & -. \\
\hline 1960 & 180,000 & 6.30 & 23,000 & 21.0 & 4,450 & 938.0 & W & W & -. & -- & -- & -. & -. & -. & 13,352 & $1,054.8$ & 82,000 & 0.04 & -. & -. \\
\hline 1961 & 114,228 & 3.99 & -- & -. & 4,080 & 816.0 & - - & -. & -. & -- & -- & -. & -- & -. & 16,133 & $1,274.5$ & 184,000 & 0.06 & -. & - - \\
\hline 1962 & 165,142 & 5.78 & -- & & 3,843 & 711.0 & - - & -- & -. & -. & -. & -. & -. & -. & 12,520 & 951.5 & - - & -- & -. & - \\
\hline 1963 & 99,000 & 3.48 & 6,100 & 9.0 & 400 & 76.0 & W & W & -. & -- & 5 & 1.1 & -. & -. & 12,322 & 961.1 & -- & -. & -. & -. \\
\hline 1964 & 58,000 & 2.05 & 7,200 & 6.0 & 303 & 95.0 & 46,400 & 60.3 & -. & -- & -. & -- & -- & -. & 13,010 & $1,522.2$ & 22,000 & 0.01 & .. & -. \\
\hline 1965 & 43,000 & 1.51 & 5,000 & 6.0 & 180 & 104.0 & 46,400 & 60.3 & -. & -. & 14 & 4.0 & -- & -. & 10,365 & $1,368.2$ & 64,000 & 0.03 & -. & -. \\
\hline 1966 & 27,325 & 0.96 & 7,000 & 9.0 & 185 & 101.0 & 16,000 & 19.2 & -. & -- & 19 & 4.3 & -- & -. & 9,033 & $1,273.7$ & -- & -. & -. & - \\
\hline 1967 & 22,948 & 0.80 & 6,000 & 9.0 & 161 & 79.0 & 20,000 & 22.0 & -. & -. & -. & -. & -. & -. & 7,888 & $1,238.4$ & W & W & -. & - \\
\hline 1968 & 21,000 & 0.81 & 3,000 & 6.5 & 156 & 78.0 & 6,000 & 6.0 & -. & -. & -. & -. & -. & -. & 8,433 & $1,652.9$ & -. & -. & -. & - \\
\hline 1969 & 21,227 & 0.88 & 2,000 & 4.2 & 238 & 100.0 & 94,000 & 100.0 & .- & .. & 2 & 0.5 & .. & .. & 8,500 & $2,321.2$ & .. & .. & .. & -. \\
\hline 1970 & 38,400 & 1.38 & 4,000 & 7.0 & 3,100 & $1,260.0$ & 365,000 & 410.0 & -. & -. & -. & -. & -. & -. & 6,015 & 925.1 & W & W & -. & -. \\
\hline 1971 & 34,000 & 1.36 & 2,000 & 4.0 & 675 & 285.0 & 68,000 & 74.0 & 34,000 & 47.0 & -- & .. & -. & .- & 5,407 & 625.6 & -. & -. & -. & -. \\
\hline 1972 & 8,639 & 0.56 & 1,000 & 2.0 & 125 & 44.0 & 160,000 & 185.0 & & W & -- & -. & -- & -. & 6,478 & 985.5 & -. & -. & -. & - - \\
\hline 1973 & 15,000 & 1.86 & 13,200 & 22.0 & 70 & 52.5 & 420,000 & 515.0 & 10,000 & 12.0 & 6 & 2.0 & -. & -. & 5,524 & 964.5 & -. & -. & -. & -. \\
\hline 1974 & 16,000 & 2.56 & 1,500 & 3.5 & 70 & 52.5 & 80,000 & 95.0 & W & W & -- & -. & -. & -. & 4,351 & $1,067.0$ & -. & -. & -. & -. \\
\hline 1975 & 14,980 & 3.35 & 6,000 & 25.0 & -. & -. & 120,000 & 145.0 & 22,000 & 60.0 & -. & - - & -- & -. & 3,726 & 623.3 & -. & -. & -. & -. \\
\hline 1976 & 22,887 & 6.90 & 6,500 & 24.0 & -- & -. & 160,000 & 165.0 & W & W & 14 & 6.0 & -- & -- & 3,212 & 515.2 & -. & -. & $8,000^{\mathrm{c}}$ & $1,200.0^{\mathrm{c}}$ \\
\hline 1977 & 50,000 & 7.80 & 8,000 & 20.0 & -. & -. & W & W & W & W & -- & -. & -. & -. & 6,891 & $1,119.8$ & -. & -. & -. & - \\
\hline 1978 & 60,000 & 12.00 & 6,000 & & -- & -. & W & W & W & W & -. & -. & -. & -. & -. & -- & -. & -. & -. & -. \\
\hline 1979 & 65,000 & 18.00 & 6,500 & 93.0 & -- & -. & 100,000 & 125.0 & 100,000 & 830.0 & -- & -- & -. & -. & -- & -- & -. & -. & -. & -. \\
\hline 1980 & 75,000 & 32.00 & 7,500 & 111.0 & & & -- & -. & 120,000 & 984.0 & 31 & 29.0 & -- & -. & $\cdots$ & & -. & -. & -. & - \\
\hline 1981 & 134,200 & 55.20 & 13,420 & 111.3 & W & W & - & -. & 106,000 & 700.0 & -- & -- & -- & -. & 900 & 200.0 & -. & -. & -. & - \\
\hline 1982 & 175,000 & 69.90 & 22,000 & 198 & -. & -. & -- & & 198,000 & $1,365.0$ & -. & -. & -. & -. & W & W & -. & -. & -. & - \\
\hline 1983 & 169,000 & 67.60 & 33,200 & 332.0 & -. & -. & 22,400 & 45.0 & 215,000 & $1,100.0$ & -. & -. & -. & -. & W & W & -. & -. & -. & - \\
\hline 1984 & 175,000 & 62. & 20,000 & 159.0 & 5 & 1.5 & 135,000 & 225.8 & 225,000 & 400.0 & -. & .. & .. & .. & W & W & .. & .. & .. & -. \\
\hline 1985 & 190,000 & & 28,500 & 171.0 & 27 & 10.0 & 65,000 & 98.0 & 300,000 & 650.0 & -. & .. & .. & .. & .. & .. & .. & .. & .. & -. \\
\hline 1986 & 160,000 & 60.80 & 24,000 & 134.4 & 12 & 2.8 & 45,000 & 67.5 & 340,000 & 890.0 & .. & .. & .. & .. & W & W & .. & .. & .. & .. \\
\hline 1987 & 229,707 & 104.51 & & & & & .. & $\ldots$ & 288,000 & 460.0 & .. & .. & .. & $\ldots$ & W & W & .. & .. & .. & .. \\
\hline 1988 & 265,500 & 112 & 47,790 & 282.0 & W & $\mathrm{W}$ & $\ldots$ & $\ldots$ & 300 , & 950.0 & & & & & 25 & 13.8 & .. & .. & .. & .. \\
\hline 1989 & 284,617 & 108.70 & $5,211,591$ & $27,300.0$ & $\therefore$ & .. & -. & NR & 194,000 & 672.0 & 9,585 & $7,700.0$ & 19,843 & $29,400.0$ & 20 & & -. & -. & -. & .. \\
\hline 1990 & 231,700 & 89.20 & $10,135,000$ & $50,675.0$ & -- & -. & -. & -. & 57,000 & 200.0 & 44,220 & $30,954.0$ & 181,200 & $253,680.0$ & -. & -. & -. & -. & -. & -. \\
\hline 1991 & 243,900 & 88 & 6,854 & & & & & & 6,800 & 22.1 & 69,591 & & & & 15 & 5.3 & -. & -. & -. & - \\
\hline 1992 & 262,5 & & 9, & & -. & -- & -. & -- & 1,500 & 5.9 & 68,664 & 31,5 & 274, & & -- & -- & -. & -. & -. & - \\
\hline 199 & 191,2 & & 58,958 & 24,33 & -- & -. & -. & -. & 21,000 & 50.6 & 38,221 & $13,759.6$ & 268, & $236,516.7$ & 3 & 1.2 & -. & -. & -- & - \\
\hline 1994 & 182,100 & 70. & $1,968,000$ & $10,391.0$ & -. & -. & -. & -. & & -. & 36,447 & $25,512.9$ & 329,003 & $296,102.7$ & 5 & 2.1 & -. & -. & -. & - \\
\hline 1995 & 141,882 & 56.04 & $1,225,730$ & $6,655.0$ & - - & .- & -. & -. & -. & -. & 58,098 & $34,428.6$ & 359,950 & $345,552.0$ & 1 & 0.4 & -. & -. & -. & -. \\
\hline 1996 & 161,565 & 62.62 & $3,676,000$ & $19,078.0$ & -- & .. & -. & .. & -. & .. & 70,086 & $52,284.0$ & 366,780 & $361,646.0$ & 2 & 0.8 & 780,000 & 0.80 & .. & -. \\
\hline 1997 & 590,516 & 207.29 & $14,401,165$ & $70,71 \mathrm{C}$ & -- & .. & -. & .. & .. & .. & 88,560 & $49,593.0$ & 419,097 & $494,888.0$ & .. & 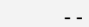 & $3,440,000$ & 3.54 & .. & .. \\
\hline 1998 & 594,191 & 174.62 & 856,000 & & .. & .. & -. & .. & .. & .. & 102,887 & $49,386.0$ & 549,348 & 505,4 & .. & -. & $3,800,000$ & 2.85 & .. & -. \\
\hline 1999 & 517,890 & 144. & $16,467,000$ & & -. & -- & -. & -. & -. & -- & 125,208 & $57,596.0$ & 643,642 & $630,769.0$ & -. & -. & $4,200,000$ & 3.00 & .. & -. \\
\hline 2000 & 551,982 & 154 & 226,615 & & -. & -. & -. & -. & -. & -. & 123,224 & $51,754.0$ & 669,112 & $682,494.0$ & -. & -. & & 2.30 & -. & -. \\
\hline 2001 & 550,644 & 149.25 & $16,798,000$ & $73,408.0$ & -- & -- & -- & -. & -. & -- & 127,385 & $56,049.0$ & 634,883 & $507,907.0$ & -- & -. & $2,800,000$ & 1.99 & -. & - \\
\hline 2002 & 562,094 & 174.28 & $17,858,183$ & $82,326.0$ & & -- & -- & -. & -. & -- & & & -. & -- & -- & & $3,200,000$ & 2.27 & -. & - \\
\hline Other ${ }^{\mathrm{c}}$ & & & & & 1,438 & -. & -. & -. & -. & -. & & -. & -. & -. & 71,946 & $17,091.9$ & & & -. & -- \\
\hline ТОTА & 07,030 & 066.32 & $164,692,716$ & $13,432.0$ & 40,945 & 10.5 & ,070,800 & 655.1 & 287,700 & 523.5 & 988,476 & 37,014.9 & $4,995,033$ & $924,534.6$ & $668,548^{d}$ & $65,815.7$ & 398,813,932 & 244.78 & 39,051 & ,426.7 \\
\hline
\end{tabular}


APPENDIX H

Production of industrial minerals, coal, and other commodities in Alaska, 1880-2002

\begin{tabular}{|c|c|c|c|c|c|c|c|c|c|}
\hline \multirow{2}{*}{ Year } & \multicolumn{2}{|c|}{ Coal } & \multicolumn{2}{|c|}{ Sand and gravel } & \multicolumn{2}{|c|}{ Rock $^{\mathrm{a}}$} & \multicolumn{2}{|c|}{ Barite } & \multirow{2}{*}{$\underset{\$}{\text { Other }}{ }^{\mathrm{b}}$} \\
\hline & s. tons & $\mathrm{m} \$$ & s. tons & $\mathrm{m} \$$ & s. tons & $\mathrm{m} \$$ & s. tons & t\$ & \\
\hline $1880-1899^{c}$ & 19,429 & 0.14 & -- & - - & 7,510 & 0.04 & - - & - - & - - \\
\hline 1900 & $1,200^{\mathrm{d}}$ & $0.02^{\mathrm{d}}$ & - - & - - & 510 & 0.01 & - - & -- & - - \\
\hline 1901 & $1,300^{\mathrm{d}}$ & $0.02^{\mathrm{d}}$ & - - & - - & 700 & 0.01 & - - & - - & 500 \\
\hline 1902 & $2,212^{d}$ & $0.02^{\mathrm{d}}$ & - - & - - & 800 & 0.01 & - - & - - & 255 \\
\hline 1903 & 1,447 & 0.01 & - - & - - & 920 & 0.01 & -- & - - & 389 \\
\hline 1904 & 1,694 & 0.01 & - - & - - & 1,080 & 0.02 & - - & - - & 2,710 \\
\hline 1905 & 3,774 & 0.02 & - - & - - & 970 & 0.02 & - - & - - & 740 \\
\hline 1906 & 5,541 & 0.02 & - - & - - & 2,863 & 0.03 & - - & - - & 19,965 \\
\hline 1907 & 10,139 & 0.05 & & - - & 3,899 & 0.03 & - - & - - & 54,512 \\
\hline 1908 & $3,107^{\mathrm{d}}$ & $0.01^{\mathrm{d}}$ & - - & - - & 2,176 & 0.03 & - - & - - & 81,305 \\
\hline 1909 & 2,800 & 0.02 & - - & - - & 1,400 & 0.01 & _. & - - & 86,027 \\
\hline 1910 & $1,000^{\mathrm{d}}$ & $0.01^{\mathrm{d}}$ & - - & - - & W & W & - - & - - & 96,408 \\
\hline 1911 & $900^{\mathrm{d}}$ & $0.01^{\mathrm{d}}$ & - - & - - & W & W & - - & - - & 145,739 \\
\hline 1912 & $355^{\mathrm{d}}$ & $0.01^{\mathrm{d}}$ & - - & - - & W & W & - - & - & 165,342 \\
\hline 1913 & 2,300 & 0.01 & - - & - - & W & W & - - & -- & 286,277 \\
\hline 1914 & 1,190 & 0.01 & - - & - - & W & W & - - & - - & 199,767 \\
\hline 1915 & 1,400 & 0.03 & - - & - - & W & W & - - & - - & 205,061 \\
\hline 1916 & 12,676 & 0.05 & - - & - - & W & W & - - & - - & 326,731 \\
\hline 1917 & 54,275 & 0.27 & - - & - - & W & W & - - & -- & 203,971 \\
\hline 1918 & 75,816 & 0.41 & - - & - - & W & W & - - & - - & 171,452 \\
\hline 1919 & 60,894 & 0.35 & - - & - - & 50,014 & 0.29 & - - & - - & 214,040 \\
\hline 1920 & 61,111 & 0.36 & - - & - - & 37,044 & 0.27 & - - & - - & 372,599 \\
\hline 1921 & 76,817 & 0.49 & - - & - - & 59,229 & 0.31 & - - & - - & 235,438 \\
\hline 1922 & 79,275 & 0.43 & - - & -- & 54,251 & 0.30 & -- & - - & 266,296 \\
\hline 1923 & 119,826 & 0.76 & - - & - - & 83,586 & 0.41 & - - & -- & 229,486 \\
\hline 1924 & 99,663 & 0.56 & -- & - - & 35,294 & 0.26 & - - & - - & 348,728 \\
\hline 1925 & 82,868 & 0.40 & -- & - - & 32,193 & 0.19 & - - & -- & 454,207 \\
\hline 1926 & 87,300 & 0.46 & - - & - - & 33,283 & 0.20 & - - & - - & 423,000 \\
\hline 1927 & 104,300 & 0.55 & -- & - - & 41,424 & 0.22 & - - & - & - - \\
\hline 1928 & 126,100 & 0.66 & - - & - - & 63,347 & 0.31 & - - & - & - - \\
\hline 1929 & 100,600 & 0.53 & - - & - - & 54,766 & 0.26 & - - & - - & 194,000 \\
\hline 1930 & 120,100 & 0.63 & - - & - - & 66,234 & 0.33 & -- & - - & 157,300 \\
\hline 1931 & 105,900 & 0.56 & - - & -- & 59,175 & 0.29 & - - & -- & 108,000 \\
\hline 1932 & 102,700 & 0.53 & - - & - - & 54,167 & 0.27 & - - & -- & 223,400 \\
\hline 1933 & 96,200 & 0.48 & - - & - - & 56,291 & 0.28 & - - & -- & - - \\
\hline 1934 & 107,500 & 0.45 & - - & - - & 64,234 & 0.36 & - - & - - & 46,155 \\
\hline 1935 & 119,425 & 0.50 & - - & - - & 74,049 & 0.38 & - - & -- & 46,755 \\
\hline 1936 & 136,593 & 0.57 & - - & - - & 76,379 & 0.38 & - - & - - & 45,807 \\
\hline 1937 & 131,600 & 0.55 & - - & - - & 50,057 & 0.25 & - - & - - & 147,048 \\
\hline 1938 & 159,230 & 0.62 & - - & - - & 189,090 & 0.21 & - - & - & 125,302 \\
\hline 1939 & 143,549 & 0.60 & 42,332 & 0.02 & - - & - - & - - & -- & - - \\
\hline 1940 & 170,174 & 0.88 & 515,011 & 0.10 & -- & -- & -- & - - & - \\
\hline 1941 & 241,250 & 0.97 & 530,997 & 0.09 & -- & -- & - - & -- & $1,367,000$ \\
\hline 1942 & 246,600 & 0.99 & W & W & -- & -- & - - & - & $1,124,000$ \\
\hline 1943 & 289,232 & 1.84 & W & W & - - & - - & - - & - - & - - \\
\hline 1944 & 352,000 & 2.37 & 712,496 & 0.50 & - - & - - & -- & - - & $2,350,309$ \\
\hline 1945 & 297,644 & 1.87 & W & W & -- & -- & - - & -- & $5,910,704$ \\
\hline 1946 & 368,000 & 2.36 & W & W & - - & - - & - - & - - & $2,005,241$ \\
\hline 1947 & 361,220 & 2.55 & W & W & 219,000 & 1.00 & -- & -- & $5,927,319$ \\
\hline 1948 & 407,906 & 2.79 & W & W & 67,341 & 0.33 & - - & - - & $1,257,699$ \\
\hline 1949 & 455,000 & 3.60 & W & W & W & W & - - & - - & $7,181,886$ \\
\hline 1950 & 421,455 & 3.03 & $3,050,020$ & 2.38 & W & W & - - & -- & $2,100,000$ \\
\hline 1951 & 494,333 & 3.77 & $6,818,000$ & 3.54 & W & W & - - & - - & $3,600,000$ \\
\hline 1952 & 648,000 & 5.77 & $6,817,800$ & 3.54 & W & W & - - & -- & $9,052,000$ \\
\hline 1953 & 861,471 & 8.45 & $7,689,014$ & 5.08 & 47,086 & 0.17 & - - & - & $1,231,350$ \\
\hline 1954 & 666,618 & 6.44 & $6,639,638$ & 6.30 & 283,734 & 0.47 & - - & -- & $1,572,150$ \\
\hline 1955 & 639,696 & 5.76 & $9,739,214$ & 8.24 & 265,740 & 0.29 & - - & -- & $1,552,427$ \\
\hline 1956 & 697,730 & 6.37 & $9,100,000$ & 8.30 & 50,000 & 0.02 & - - & - & $1,551,500$ \\
\hline 1957 & 842,338 & 7.30 & $6,096,000$ & 8.79 & 528,000 & 1.95 & - - & - - & $2,751,000$ \\
\hline 1958 & 759,000 & 6.93 & $4,255,000$ & 3.87 & 615,000 & 2.07 & - - & - - & 695,000 \\
\hline 1959 & $602,000^{\mathrm{d}}$ & $5.88^{\mathrm{d}}$ & $5,600,000$ & 5.10 & 54,000 & 0.20 & $\ldots$ & $\ldots$ & $1,338,000$ \\
\hline
\end{tabular}




\begin{tabular}{|c|c|c|c|c|c|c|c|c|c|}
\hline \multirow[b]{2}{*}{ Year } & \multicolumn{2}{|c|}{ Coal } & \multicolumn{2}{|c|}{ Sand and gravel } & \multicolumn{2}{|c|}{ Rock $^{\mathrm{a}}$} & \multicolumn{2}{|c|}{ Barite } & \multirow{2}{*}{$\begin{array}{c}\text { Other }^{b} \\
\$\end{array}$} \\
\hline & s. tons & $\mathrm{m} \$$ & s. tons & $\mathrm{m} \$$ & s. tons & $\mathrm{m} \$$ & s. tons & $\mathrm{t} \$$ & \\
\hline 1960 & $669,000^{\mathrm{d}}$ & $5.95^{\mathrm{d}}$ & $5,892,000$ & 5.35 & 80,000 & 0.30 & - - & - - & 975,000 \\
\hline 1961 & $650,000^{\mathrm{d}}$ & $5.87^{\mathrm{d}}$ & $5,241,000$ & 4.19 & - - & - - & - - & - - & - - \\
\hline 1962 & $675,000^{\mathrm{d}}$ & $6.41^{\mathrm{d}}$ & $5,731,000$ & 5.36 & - - & - - & - - & - - & - - \\
\hline 1963 & 853,000 & 5.91 & $16,926,000$ & 22.01 & W & W & W & W & $2,589,000$ \\
\hline 1964 & 745,000 & 5.01 & $26,089,000$ & 18.49 & W & W & W & W & $4,912,000$ \\
\hline 1965 & $860,000^{\mathrm{d}}$ & $5.88^{\mathrm{d}}$ & $29,959,000$ & 33.93 & W & W & W & W & $5,296,000$ \\
\hline 1966 & 927,000 & 6.95 & $17,457,000$ & 21.79 & W & W & 44,000 & 350.0 & $6,167,000$ \\
\hline 1967 & 930,000 & 7.18 & $22,300,000$ & 26.25 & W & W & W & W & $4,924,000$ \\
\hline 1968 & $812,000^{d}$ & $5.03^{\mathrm{d}}$ & $17,515,000$ & 20.73 & W & W & 91,000 & W & $4,117,000$ \\
\hline 1969 & $728,000^{d}$ & $4.65^{\mathrm{d}}$ & $16,205,000$ & 18.62 & $1,954,000$ & 3.90 & 90,000 & 850.0 & $5,163,000$ \\
\hline 1970 & $786,000^{d}$ & $5.28^{\mathrm{d}}$ & $20,375,000^{d}$ & $26.07^{d}$ & $6,470,000$ & 10.01 & $134,000^{d}$ & $1,875.0$ & $7,994,000$ \\
\hline 1971 & $748,000^{\mathrm{d}}$ & $5.05^{\mathrm{d}}$ & $26,391,000$ & 41.99 & $2,658,000$ & 5.07 & $102,000^{\mathrm{d}}$ & $1,075.0$ & - - \\
\hline 1972 & $720,000^{d}$ & $6.26^{\mathrm{d}}$ & $14,187,000$ & 15.21 & 652,000 & 3.01 & W & W & - - \\
\hline 1973 & $700,000^{\mathrm{d}}$ & $6.23^{\mathrm{d}}$ & $19,350,000$ & 19.01 & $5,967,000$ & 12.00 & 112,000 & $1,792.0$ & $12,846,000$ \\
\hline 1974 & 700,000 & 7.34 & $118,740,000^{\mathrm{d}}$ & $240.94^{\mathrm{d}}$ & $5,484,000$ & 12.95 & 110,000 & $1,895.0$ & $14,495,000$ \\
\hline 1975 & 766,000 & 7.81 & $48,145,000$ & 95.78 & $8,877,000$ & 26.65 & $2,000^{d}$ & 30.0 & $12,731,000$ \\
\hline 1976 & 705,000 & 8.00 & $74,208,000^{\mathrm{d}}$ & $204.73^{d}$ & $6,727,000$ & 20.09 & W & W & $14,019,000$ \\
\hline 1977 & $780,000^{\mathrm{d}}$ & $12.00^{\mathrm{d}}$ & $66,126,000$ & 134.25 & $4,008,000$ & 17.47 & - - & - - & $14,486,000$ \\
\hline 1978 & 750,000 & 15.00 & $51,100,000$ & 122.00 & $3,437,000$ & 14.65 & 22,000 & 750.0 & - - \\
\hline 1979 & 750,000 & 16.00 & $50,900,000$ & 104.90 & $3,650,000$ & 15.45 & 20,000 & 800.0 & 930,000 \\
\hline 1980 & 800,000 & 16.00 & $40,000,000$ & 86.00 & $3,700,000$ & 15.40 & 50,000 & $2,000.0$ & 97,500 \\
\hline 1981 & 800,000 & 17.60 & $46,000,000$ & 88.20 & $4,200,000$ & 19.30 & - - & - - & 256,000 \\
\hline 1982 & 830,000 & 18.00 & $45,000,000$ & 91.00 & $3,400,000$ & 15.60 & - - & - - & 150,000 \\
\hline 1983 & 830,000 & 18.00 & $50,000,000$ & 105.00 & $5,270,000$ & 25.00 & - - & - - & 242,000 \\
\hline 1984 & 849,161 & 23.75 & $27,000,000$ & 95.00 & $2,700,000$ & 16.00 & - - & - - & 875,875 \\
\hline 1985 & $1,370,000$ & 39.73 & $28,184,080$ & 112.06 & $2,500,000$ & 12.00 & - - & - - & 559,000 \\
\hline 1986 & $1,492,707$ & 40.10 & $20,873,110$ & 75.76 & $4,200,000$ & 20.32 & - - & - - & 384,800 \\
\hline 1987 & $1,508,927$ & 42.35 & $16,696,374$ & 42.66 & $1,805,000$ & 11.62 & - - & - & 388,400 \\
\hline 1988 & $1,551,162$ & 44.30 & $17,264,500$ & 48.75 & $3,600,000$ & 24.65 & - - & - & 389,000 \\
\hline 1989 & $1,452,353$ & 41.46 & $14,418,000$ & 39.88 & $2,914,000$ & 20.34 & - - & - - & $1,492,000$ \\
\hline 1990 & $1,576,000$ & 44.99 & $15,013,500$ & 40.82 & $3,200,000$ & 22.10 & - - & - - & 400,000 \\
\hline 1991 & $1,540,000$ & 39.00 & $14,160,011$ & 45.45 & $3,000,000$ & 22.50 & - - & - - & 462,000 \\
\hline 1992 & $1,531,800$ & 38.30 & $14,599,746$ & 42.20 & $2,900,000$ & 22.97 & - - & - - & 430,000 \\
\hline 1993 & $1,586,545$ & 38.10 & $13,162,402$ & 40.64 & $3,561,324$ & 26.21 & - - & - - & 465,000 \\
\hline 1994 & $1,490,000$ & 36.75 & $13,518,321$ & 40.95 & $3,843,953$ & 27.04 & - - & - - & 459,500 \\
\hline 1995 & $1,640,000$ & 41.30 & $9,847,550$ & 30.8 & $2,811,152$ & 22.13 & - - & - - & 182,500 \\
\hline 1996 & $1,481,000$ & 38.00 & $9,890,463$ & 32.20 & $3,000,045$ & 23.56 & - - & -- & 200,000 \\
\hline 1997 & $1,446,000$ & 38.05 & $13,800,000$ & 51.91 & $3,200,000$ & 20.00 & - - & - - & 217,000 \\
\hline 1998 & $1,339,000$ & 35.23 & $12,363,450$ & 57.28 & $1,636,200$ & 14.04 & - - & - - & 215,000 \\
\hline 1999 & $1,560,000$ & 41.05 & $10,600,000$ & 52.42 & $1,640,000$ & 18.01 & - - & - & - - \\
\hline 2000 & $1,473,355$ & 38.77 & $10,600,000$ & 49.86 & $5,200,000$ & 36.59 & - - & - - & - - \\
\hline 2001 & $1,537,000$ & 48.11 & $10,360,000$ & 55.22 & $3,091,000$ & 27.18 & - - & - - & - - \\
\hline 2002 & $1,158,000$ & 37.40 & $22,412,000$ & 120.70 & $3,152,000$ & 31.44 & - - & - - & - - \\
\hline Other ${ }^{d}$ & - - & - & - & - - & $2,300,000^{\mathrm{e}}$ & W & 79,000 & W & - \\
\hline TOTAL $^{\mathrm{f}}$ & $58,342,335$ & $1,056.26$ & $1,196,206,000$ & $2,682.3$ & $130,176,000$ & 648.04 & 856,000 & $11,417.00$ & $177,761,872$ \\
\hline
\end{tabular}

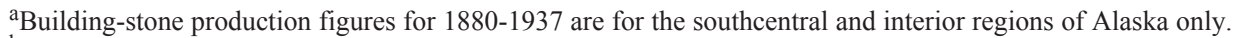

bIncludes 2.4 million $\mathrm{lb} \mathrm{U}_{3} \mathrm{O}_{8}$ (1955-71); 505,000 tons gypsum (1905-26); 286,000 lb WO (intermittently 1916-80); 94,000 lb asbestos (1942-44); 540,000 lb graphite (1917-18 and 1942-50); and undistributed amounts of zinc, jade, peat, clay, soapstone, miscellaneous gemstones, and other commodities (1880-1993).

cProduction not traceable by year.

${ }^{\mathrm{d}}$ When state (territorial) and federal figures differ significantly, state figures are used. Figures for sand and gravel production in 1974 show state estimates $(118,740,000 \mathrm{~s}$. tons; $240.94 \mathrm{~m} \$)$ and federal $(42,614,000 \mathrm{~s}$. tons; $88.96 \mathrm{~m} \$)$. The federal estimate was not added to total production.

eMarble quarried on Prince of Wales Island, southeastern Alaska (1900-41).

fRounded to nearest 1,000 ton.

$\mathrm{m} \$=$ Million dollars.

$\mathrm{t} \$=$ Thousand dollars.

- - = Not reported.

$\mathrm{W}=$ Withheld. 
6. Kougarok district

17. Cape Nome district
18. Council-Solomon district
19. Koyuk district

20. Koyukuku-Hughes distric

21. Kaiyah district

23. Marshall district

Bethel district

Goodnews Bay district
Aniak-Tuluksak district

27. Initarod district
28. McGrath-McKinley distric
29. Innoko-Tolstoi district

2. Innoko-Tolstoi district

31. Kantishna district

32. Hot Springs district

35. Ramparts district

35. Tolovana-Livengood district

36. Yukon Flats distric

37. Circle district

39. Eagle district

40. Fortymile district
41. Chisana-Nabesna district

42. Thisana-Nabes district

43. Goodpaster district

44. Fairbanks district
45. Bonnifield district

46. Richardsorizdistrict

7. Delta River districtic
48. Chistochina district

9. Valdez Creek district

50. Yentna-Cache Creek district

Redoubt district

2. Illiamna-Bristol Bay district

4omer district

Hope-Sunrise

6. Anchorage districte ${ }^{\mathrm{e}}$

77. Willow Creek-Hatcher Pass distri
8. Prince William Sound district

Nelchina district

Nizina district
Yakataga district

Yukutat district $f^{f}$

63. Porcupine district
64. Juneau \& Admirality districts

Chichagof district
Petersburg-Sumdum distric

67. Kupreanof district

68. Hyder district
69. Ketchikan district

SUBTOTAL
Undistributed

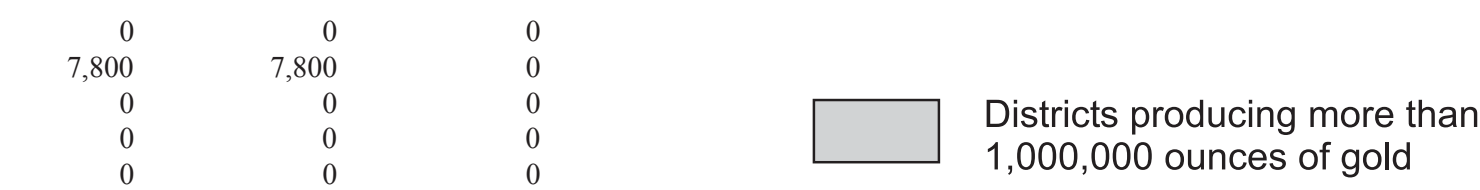

$1,000,000$ ounces of gold

$\begin{array}{rr}0 & \\ 65,860 & 48, \\ 344,983 & 344,983 \\ 15,000 & \end{array}$

$\begin{array}{rr}344,983 & 344,983 \\ 15,000 & 15,000 \\ 40,600 & 40,600\end{array}$

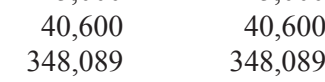

$\begin{array}{rr}253,720 & 253,720 \\ 4,220 & 4,220\end{array}$

$\begin{array}{rr}42,351 & 42,35 \\ 176,776 & 176,776\end{array}$

$\begin{array}{ll}4,988,928 & 4,988,928\end{array}$

$1,019,513$
84,132

258,344
131,843

$\begin{array}{rr}124,506 & 124,506\end{array}$

$29,700 \quad 29,700$

$\begin{array}{rr}584,473 & 584,473 \\ 1,562722 & 1,599,792\end{array}$

\begin{tabular}{rr}
$1,562,722$ & $1,559,792$ \\
329,393 & 132,494 \\
727,794 & 727,638 \\
\hline 47,477 & 477,477
\end{tabular}

$\begin{array}{ll}727,794 & 727,638 \\ 477,477 & 477,477 \\ 57,907 & 97,996\end{array}$

$\begin{array}{rr}99,307 & 91,40 \\ 577,956 & 577,956\end{array}$

$\begin{array}{rr}12,089 & 12,089 \\ 196,699 & 196,699\end{array}$

$\begin{array}{rr}529,466 & 529,466 \\ 0 & 0\end{array}$

$1,062,005 \quad 1,062,005$

$\begin{array}{rr}0 & 52,000 \\ 54,000\end{array}$

$548,114 \quad 548,114$

$\begin{array}{rr}280 & 280 \\ 2,350 & 2,050\end{array}$

$10,762,951 \quad 8,174,987$

$\begin{array}{rr}82,650 & 75,950 \\ 120,940 & 118,640\end{array}$

$\begin{array}{rr}6,740 & 6,740 \\ 181,842 & 181,842\end{array}$

$508,554 \quad 506,973$

$197,690 \quad 197,690$

1,570

$\begin{array}{rr}16 & 16 \\ 132,442 & 67,442\end{array}$

$666,175 \therefore \quad 0 \quad 05,000$

$137,715^{\circ 9}$. $1427,675 \cdot 609,000^{\circ}=0$

148,500
18,040

13,200

81,440

$8,449,521$

15,000

219

$37,396,760$

154,142
$37,550,902$
BACK Cover, Top. Red Dog Mine and mine complex with fall foliage. Red of Teck Cominco Alaska Inc.

BACK COVER, MIDDLE CENTER. The sales terminal pile and stacking conconveyor has a 250,000-ton surge capacity. Photo courtesy of Anchorage Sand d Gravel Co. Inc.

Cutomatic load out at Anchorage Sand \& Gravel Co. Inc.'s sales terminal pile. The facility is able to handle 2,200 Sand \& Gravel Co. In

BaCK Cover, Left BotTom. Peter Nyren prepares a soil auger for drilling on the Rob property in the Goodpaster area during Freegold Ventures

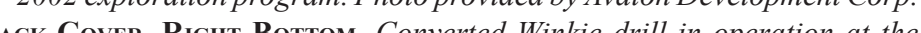
Brushy Creek massive-sulfide prospect on Woewodshi Island. Drill capable of 250 feet of $A$ rod ( $\approx 1.1$ inch core diameter) or 300 feet using combination of $A$ and $E$ rod $(\approx 0.9$ inch core diameter). Photo courtesy of Olympic Resources Group LLC 

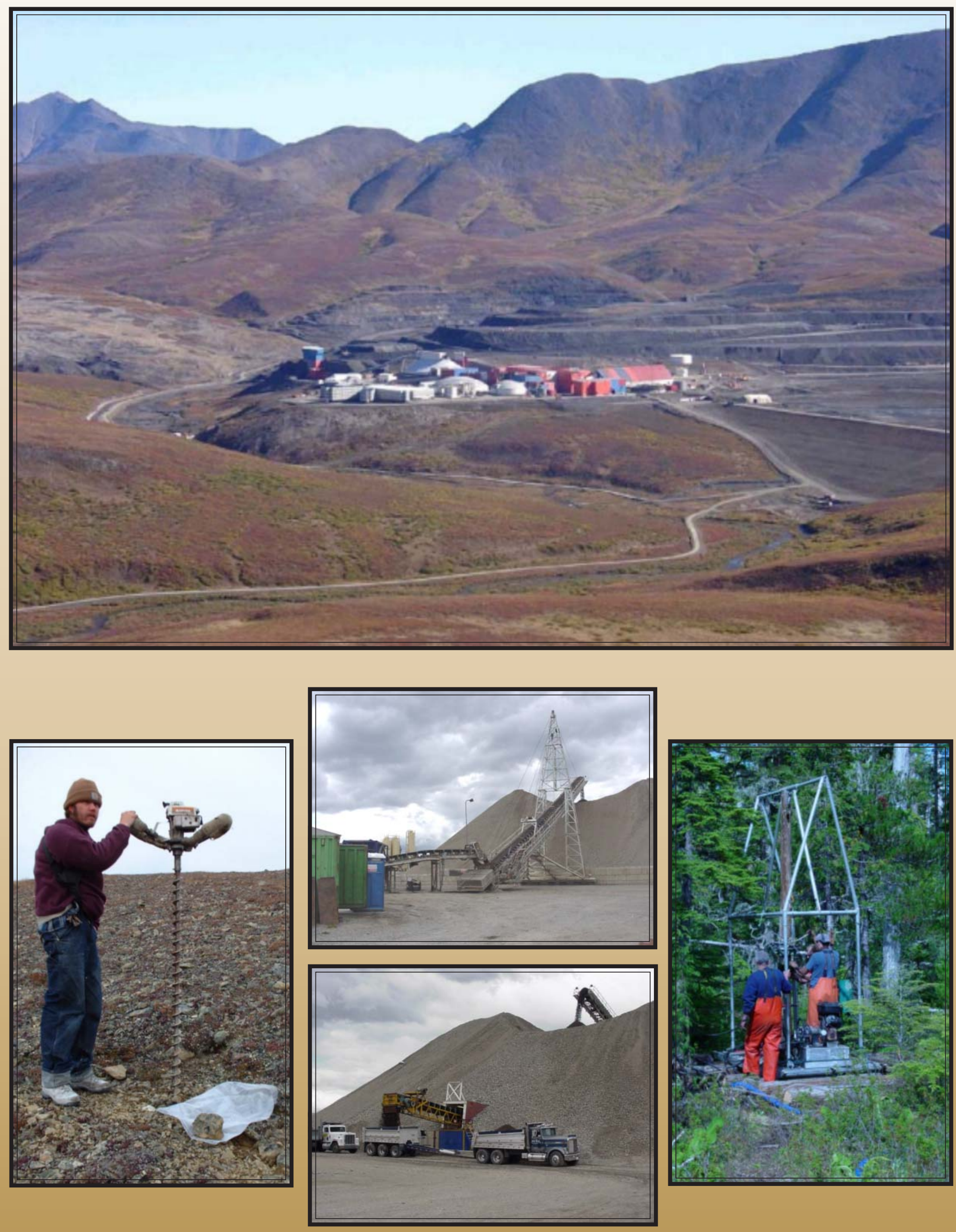